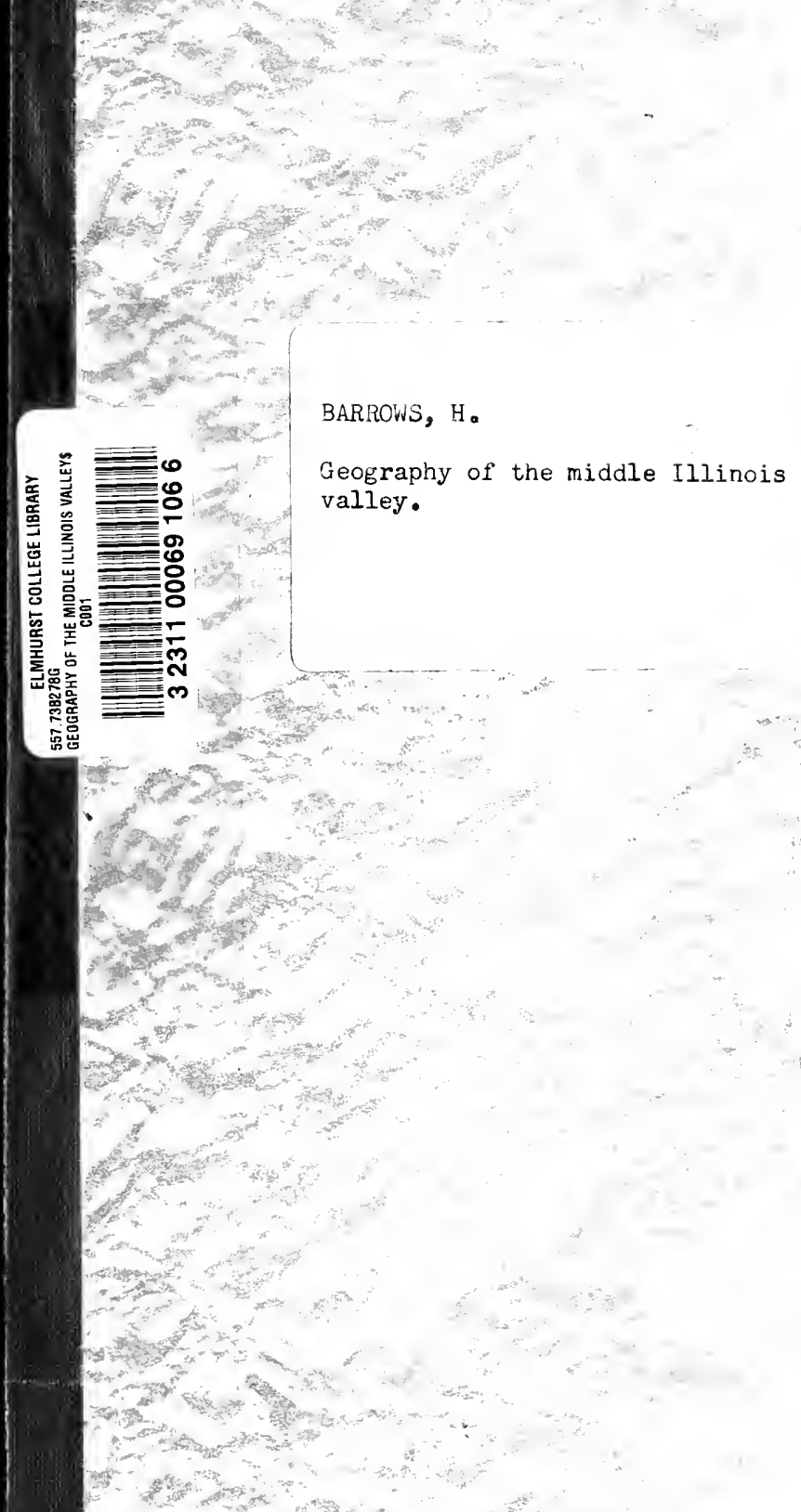




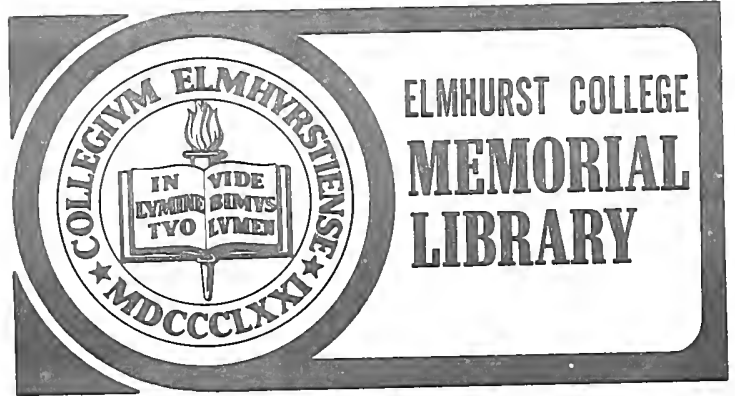


STATE OF ILLINOIS

DEPARTMENT OF REGISTRATION AND EDUCATION

DIVISION OF THE

STATE GEOLOGICAL SURVEY

M. M. LEIGHTON, Chief

BULLETIN No. 15

\title{
GEOGRAPHY OF THE MIDDLE ILLINOIS VALLEY
}

BY

HARLAN H. BARROWS

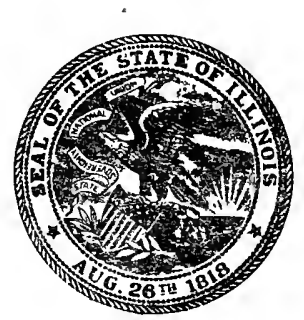

PRINTED BY AUTHORITY OF THE STATE OF ILLINOIS

\author{
URBANA, ILLINOIS \\ 1910
}

REPRINTED 1925

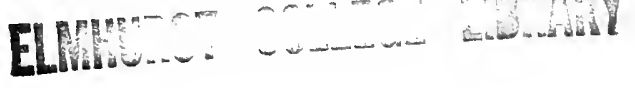




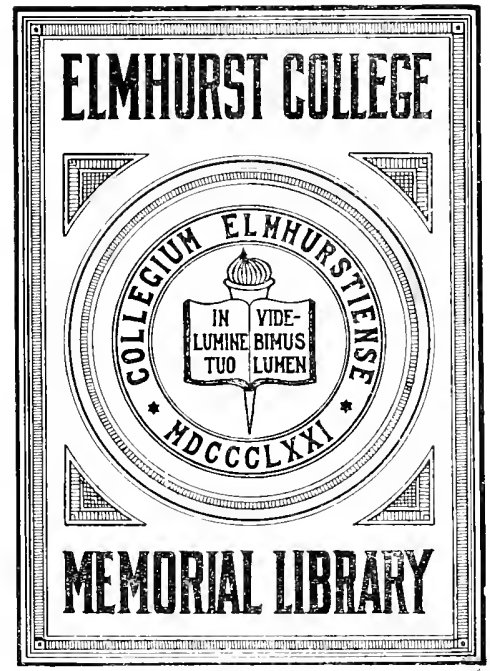


STATE OF ILLINOIS

DEPARTMENT OF REGISTRATION AND EDUCATION

DIVISION OF THE

STATE GEOLOGICAL SURVEY

M. M. LEIGHTON, Chief

BULLETIN No. 15

\section{GEOGRAPHY OF THE MIDDLE ILLINOIS VALLEY}

BY

HARLAN H. BARROWS

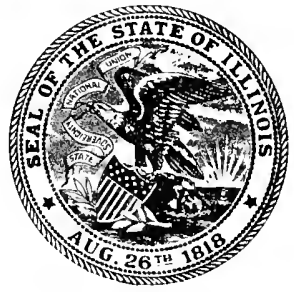

PRINTED BY AUTHORITI OF THE NTATE OF ILLINOIS

URBANA, ILLINOIS

1910

REPRINTED 1925 

557.73
$B 278 \mathrm{~g}$

STATE OF ILLINOIS

DEPARTMENT OF REGISTRATION AND EDUCATIGN

DIVISION OF THE

STATE GEOLOGICAL SURVEY

M. M. LEIGHTON, Chief

Committee of the Board of Natural Resources and Conservation

A. M. Sineltox, Chairman

Director of Registration and Education

KendRIC C. Babcock

Representing the President of the U.li. versity of Illinois

EDson S. BastiN

Geologist

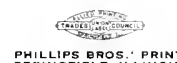

PHILLIPS EROS: PRINT

140.7 



\section{TABLE OF CONTENTS.}

List of illustrations............................................

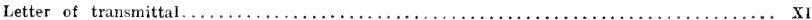

\section{CHAPTER I-THE PHYSIOGRAPHIC FEATURES OF THE REGLON.}

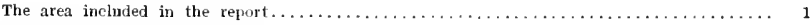

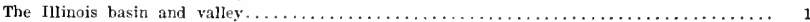

Variable width of the valley $\ldots \ldots \ldots \ldots \ldots \ldots \ldots \ldots \ldots \ldots \ldots \ldots \ldots \ldots \ldots \ldots \ldots \ldots \ldots \ldots, 1$

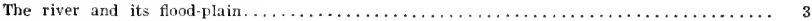

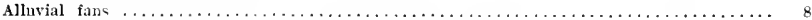

Terraces $\ldots \ldots \ldots \ldots \ldots \ldots \ldots \ldots \ldots \ldots \ldots \ldots \ldots \ldots \ldots \ldots \ldots \ldots \ldots \ldots \ldots \ldots \ldots, 11$

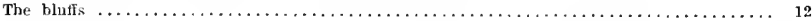

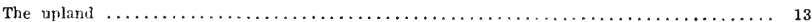

The small valleys $\ldots \ldots \ldots \ldots \ldots \ldots \ldots \ldots \ldots \ldots \ldots \ldots \ldots \ldots \ldots \ldots \ldots \ldots \ldots \ldots \ldots \ldots \ldots \ldots \ldots$ 14

The clay ridge ${ }^{2} \ldots \ldots \ldots \ldots \ldots \ldots \ldots \ldots \ldots \ldots \ldots \ldots \ldots \ldots \ldots \ldots \ldots \ldots \ldots \ldots \ldots \ldots \ldots, 14$

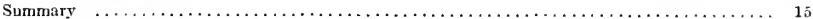

\section{CHAPTER II-THE BED ROCKS OF THE REGION.}

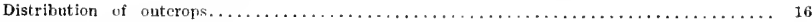

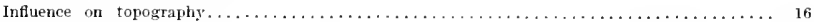

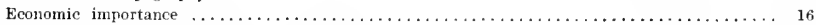

Characteristics and origin of the sandstone $\ldots \ldots \ldots \ldots \ldots \ldots \ldots \ldots \ldots \ldots \ldots \ldots \ldots \ldots \ldots \ldots$

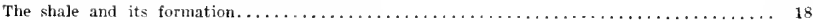

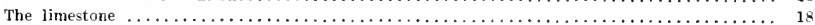

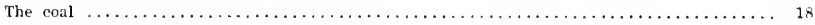

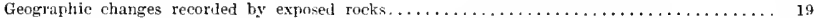

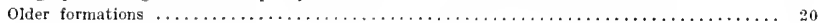

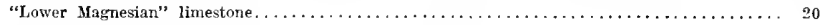

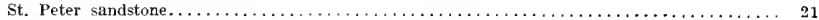

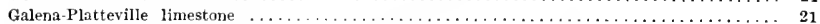

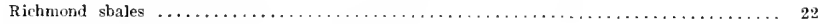

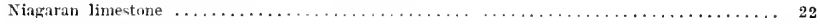

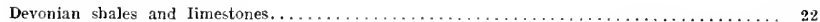

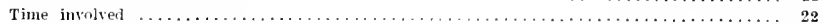

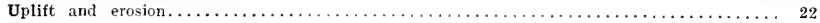

\section{CIIAPTER III-THE GLACIAL PERIOD.}

The mantle rock of the area is of foreign derivation $\ldots \ldots \ldots \ldots \ldots \ldots \ldots \ldots \ldots \ldots \ldots \ldots$

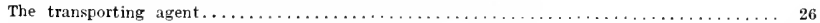

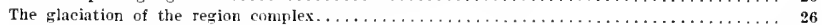

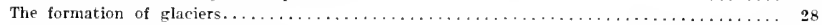

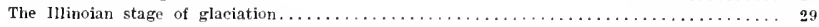

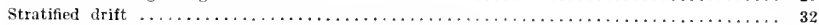

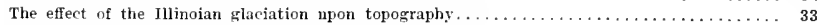

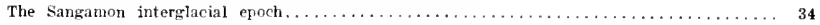

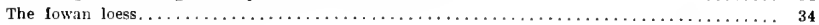

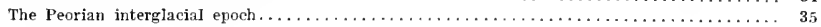




\section{Table of Contents-Continued.}

The Farly Wh PAGE

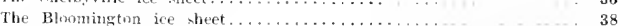

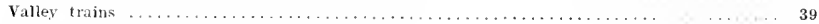

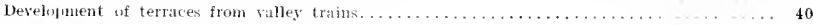

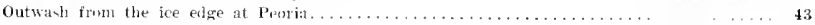

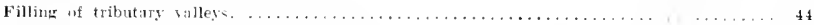

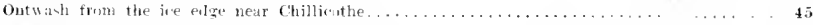

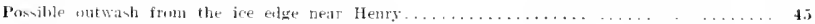

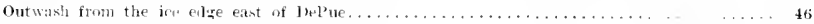

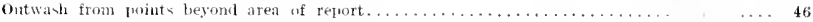

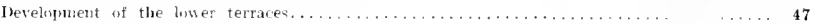

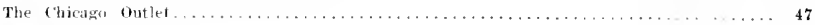

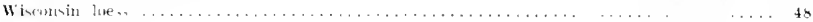

('HAPTER IY-PUST-GLACIIL CHANGES.

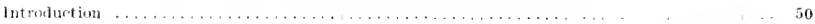

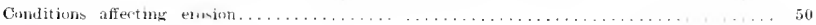

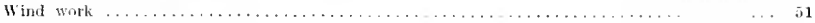

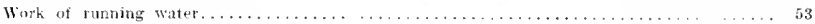

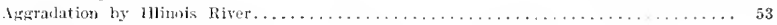

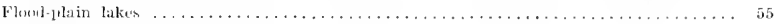

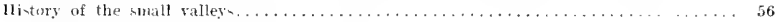

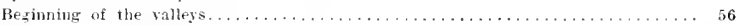

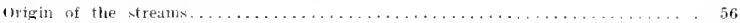

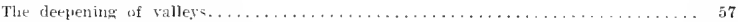

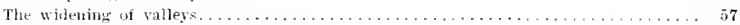

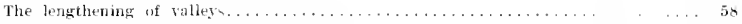

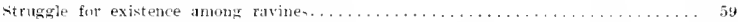

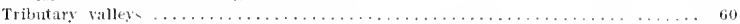

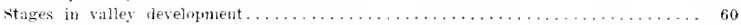

Influence of lllinois River upn configuration of small valleys. . . . . . . . . 61

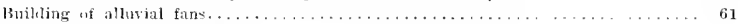

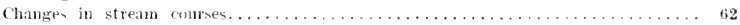

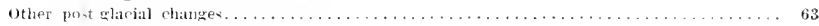

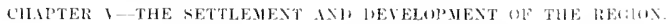

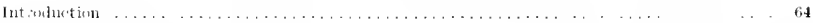

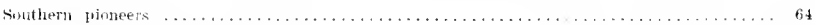

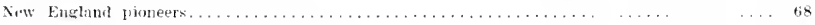

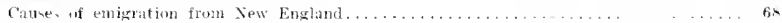

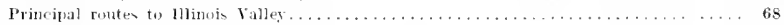

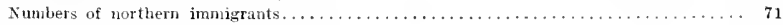

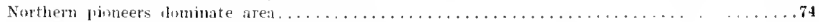

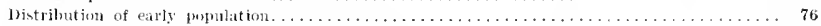

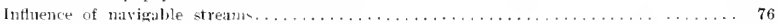

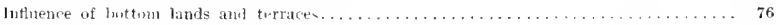

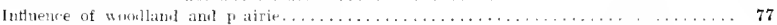

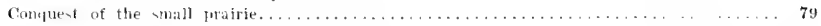

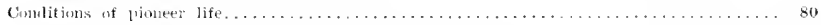

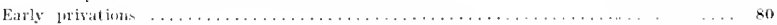

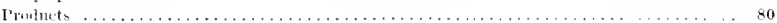

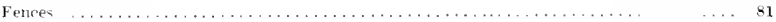

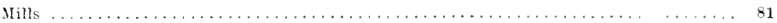

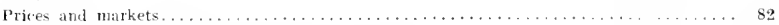

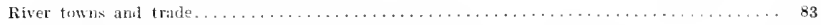

Physiographic conditions determine town sites....................... 83

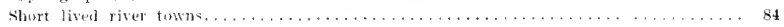

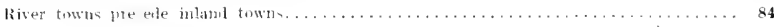




\section{Table of Contents-Concluded.}

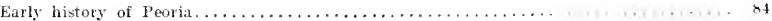

Advent of steamboat aud develupment of river town $\ldots \ldots \ldots \ldots \ldots \ldots \ldots \ldots \ldots \ldots$;

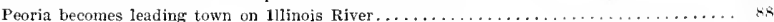

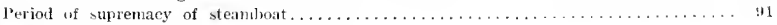

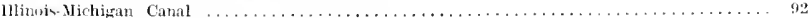

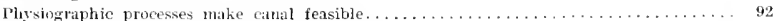

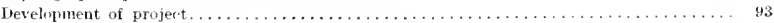

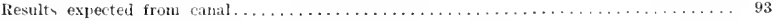

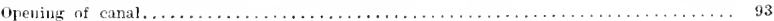

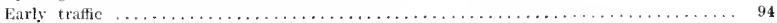

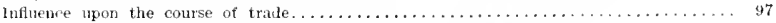

Infuence of lllinois River and canal upon population and products of regisin . . . . . . . . 99

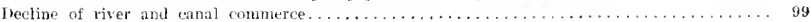

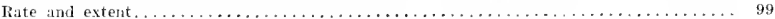

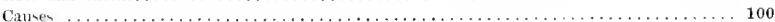

Eflert unon river towns. . . . . . . . . . . . . . . . . . .

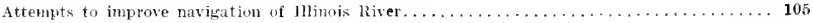

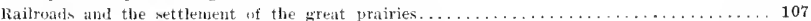

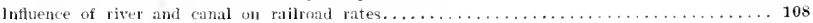

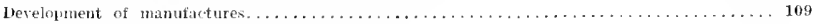

Early indutries

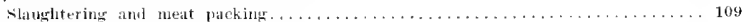

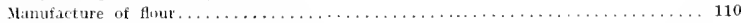

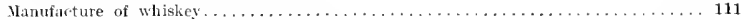

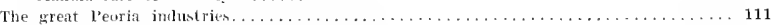

Aivantages of peoria as industrial center $\ldots \ldots \ldots \ldots \ldots \ldots \ldots \ldots \ldots \ldots \ldots \ldots \ldots \ldots$

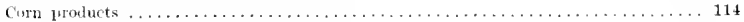

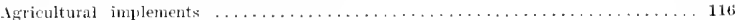

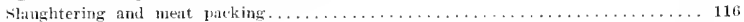

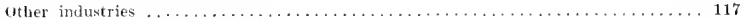

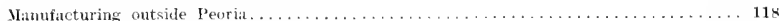

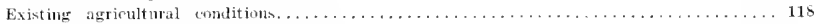

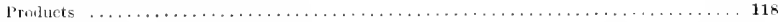

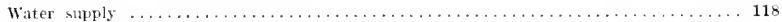

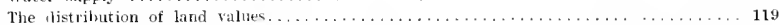

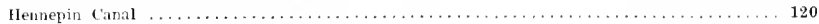

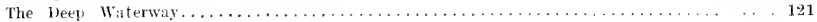

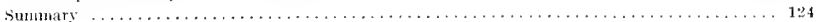




\section{LIST OF ILLUSTRATIONS.}

FACING

PLITE,

PAGE

Frontispiece-Ilinois Valley, looking north from Prospect Height, Peoria............ 1

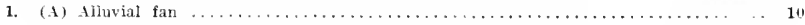

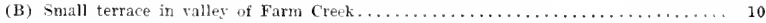

Map showing small valleys southeast of Peoria................. 12

3. (A) View of Illinois Valley north of Peoria, showing terraces and bluffs of east side.... 14

(B) View of Illinois Villey north of Peoria, showing terrace and lower blufs of

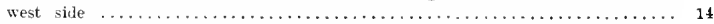

4. (A) Low bluffs of irentle shie north of Buresta $\ldots \ldots \ldots \ldots \ldots \ldots \ldots \ldots \ldots \ldots \ldots \ldots$

(B) Depositional slope leveluted by rain wash $\ldots \ldots \ldots \ldots \ldots \ldots \ldots \ldots \ldots \ldots \ldots \ldots \ldots 16$

5. (A) Exposure of Penn-yluabian rocks in Rowe's Hollow, southwest of Henry....... 18

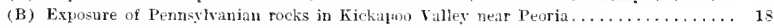

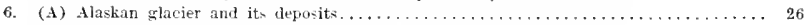

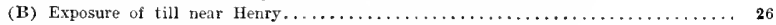

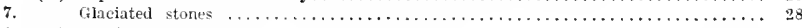

8. (A) Morainic topography in northern part of area $\ldots \ldots \ldots \ldots \ldots \ldots \ldots \ldots \ldots \ldots \ldots \ldots$

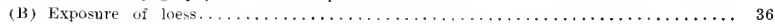
Exposure of material in a valley train, showing structure of beds......... 40

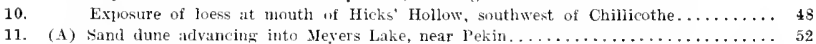

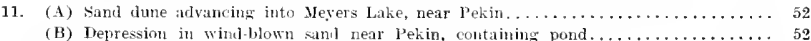

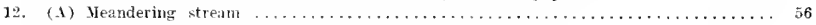

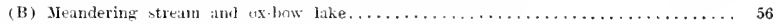

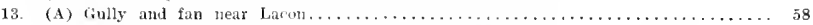

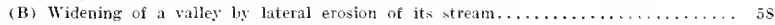

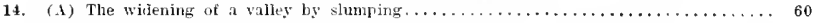

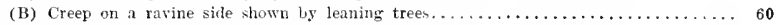

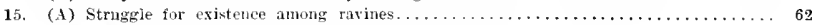

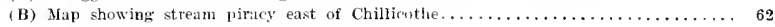

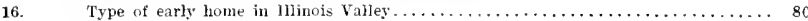

Figtres

Figure

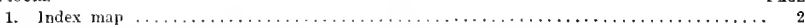

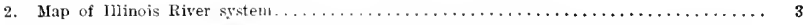

3. Map showing general dijtribution of leading teatures of region $\ldots \ldots \ldots \ldots \ldots \ldots \ldots \ldots, 5$

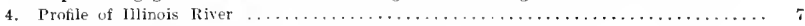

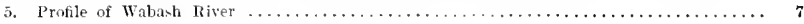

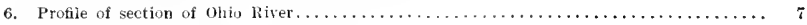

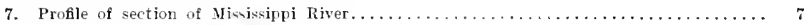

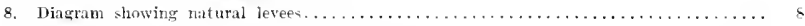

9. Map showing flond-plain lakes near Henr. $\ldots \ldots \ldots \ldots \ldots \ldots \ldots \ldots \ldots \ldots \ldots \ldots \ldots . . \ldots$

10. Diagran showing stricture of river deposits $\ldots \ldots \ldots \ldots \ldots \ldots \ldots \ldots \ldots \ldots \ldots \ldots \ldots \ldots 10$

11. Diagram showing a thoml-plain, terrace, and uplind, and their relation to one another... 11

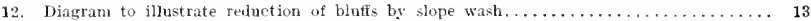

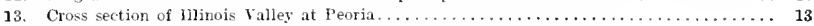

14. Profile showing irregular topography occasioned by small valleys............. 14 


\section{List of Illustrations-Concluded.}

15. Section of rock formations of uorthern pontion of region, nestrated by deep borings. . . 21

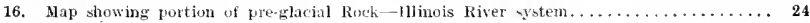

17. Jiagram showing relation of revilual soil to bnderlying rock $\ldots \ldots \ldots \ldots \ldots \ldots \ldots \ldots \ldots 25$

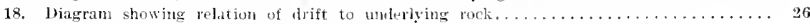

19. Jap showing maximum extent it ise byets of filirial period in Forth America...... 27

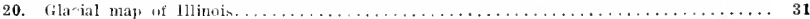

21. Diagran illustrating how rough fre-glacial topography may be repraced by smooth

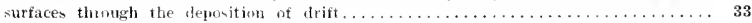

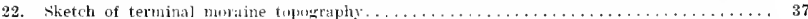

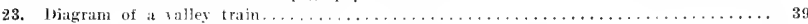

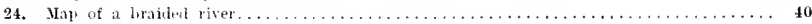

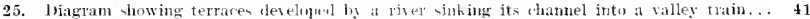

26. biagram thowing how a river mav destroy teratep by side rutting............41

27. Diagram illutrating development of terrates by a slowly degrading riva which shifts

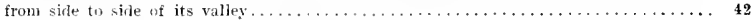

28. Hiagram illutrating two sets of terruen, developed from aggradational flats....... 42

29. Diagram to illustrate relations of terdaces of mnequal helght to one another........42

30. Sketch showing how wind.blown xand itcumulates about an inpenetrahle obstacle..... 51

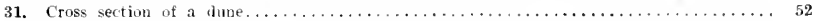

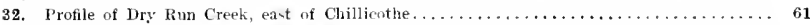

33. May showing distrihution and densty uf population in []linois in $1824 \ldots \ldots \ldots \ldots .65$

34. Jap show ing distribution and densty of fopulation in Illinois in $1830 \ldots \ldots \ldots \ldots \ldots .67$

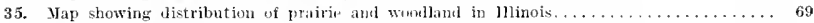

36. Map showing listribution and density of fwhulation in minois in $1840 \ldots \ldots \ldots \ldots .72$

37. Map showing distribution and den-ity of gornlation in lllinois in $1850 \ldots \ldots \ldots \ldots \ldots .73$

38. Map showing distribution and denity of fropulation in 1llinois in 18 ti0 ......... 7 ;

39. Hap showing original dintribution of wogdland and prairie in Bureau Cunty . . . . . 79

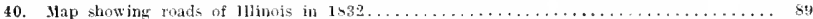

41. Graph showing tolls collected hy lllimoin and Hichigan Canal from 1sts to 1907..... 101

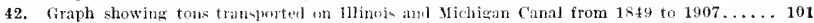

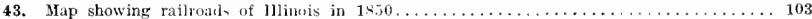

44. Map showing railroads of lllinois in $1860 \ldots \ldots \ldots \ldots \ldots \ldots \ldots \ldots \ldots \ldots \ldots \ldots \ldots \ldots$

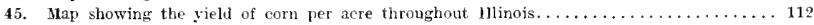

46. Map showing the perrentage ot the total area which is devotel to corn culture throughout tllinois $\ldots \ldots \ldots \ldots \ldots \ldots \ldots \ldots \ldots \ldots \ldots \ldots \ldots \ldots \ldots \ldots \ldots \ldots \ldots \ldots$

47. Map showing route of Hennepin Canal $\ldots \ldots \ldots \ldots \ldots \ldots \ldots \ldots \ldots \ldots \ldots \ldots \ldots \ldots \ldots \ldots$ 



\title{
FIRST LETTER OF TRANSMITTAL.
}

\author{
State Geulogical SURVer. \\ UNIVERSTT OF JlLinoIs, March 22, 1910.
}

Hon. C. S. Mencen. Chairman, and Members of the Geological Commission:

GENTLEMEN-I submit herewith a report on the Geography of the Middle Illinois Valley, with the recommendation that it be publisherl as Bulletin No. 15 of the Surves. This is the fifth contribution to our series of "Educational Bulletins" prepared under the general direction of Professor R. D. Salisbury, Consulting Geologist of the Survey.

Professor Harlan H. Parrows, the author, has based this report on field work in 1906-07 along Illinois River between Peoria and Hennepin. He has also drawn on his extended experience at the Lniversity of Chicago in teaching and research work on problems of community development as affected by enviromment. The main physiographic features of this region, which inmpress all close observers, are first described and interpreted. This is follomed by a study of the rocks, including as they do valuable becis of coal, shale, limestone and waterbearing sandstone. Other chapters reveal, in the history of the glacial period, the sequence of events in this area which account for the present physiography. A final chapter of most interesting historical character describes the settlement and levelopment of the PeoriaHennepin region from the time of the pioneers who emigrated from the South and from New England. The distribution of the early population, its conquest of adverse conditions and final development into a community of great interests, is skillfully traced.

Of timely interest is the history of the Jllinois-Nichigan Canal and the discussion of the conditions which brought about its rise and decline. The Hennepin Canal is also described. Finally, the writer reviews the factors affecting the Deep IVaterway movement.

General readers and particularly teachers and students residing in the area under discussion will have a clearer understanding of the home region after reading this report and noting its numerous illustrations. But, in addition, all students of Illinois history and of modem geography will find the report extremely helpful. 
The author has acknowledged the use of a number of illustrations and of the reports of Mr. Frank Leverett and others of the U. S. Geological Survey, and of Mr. Lyman E. Cooley. The Survey expresses its thanks to these gentlemen and to the author of the report and to Professor Salisbury for his supervision.

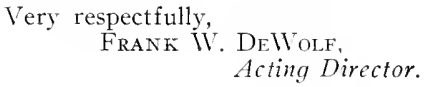

\section{SECOND LETTER OF TRANSMITTAL.}

State Geological Survey.

Urbana, Illinois, September 12, 1925.

A. M. Shelton, Chairman, and Mcmbers of the Board of Natural Resontes and Conservation:

Gentlenen-The preparation of this report as one of our educational bulletins was originally done with the greatest of care by the author under the general direction of the late Professor R. D. Salisbury. The accomplishment has been fully justified by the popularity with which the report has been received. The first edition has been exhausted and continued calls make this second edition very desirable.

Some slight revisions have been made here and there throughout the report, but it remains essentially as the author originally wrote it. Respectfully yours,

iI. M. Leighton, Chief. 



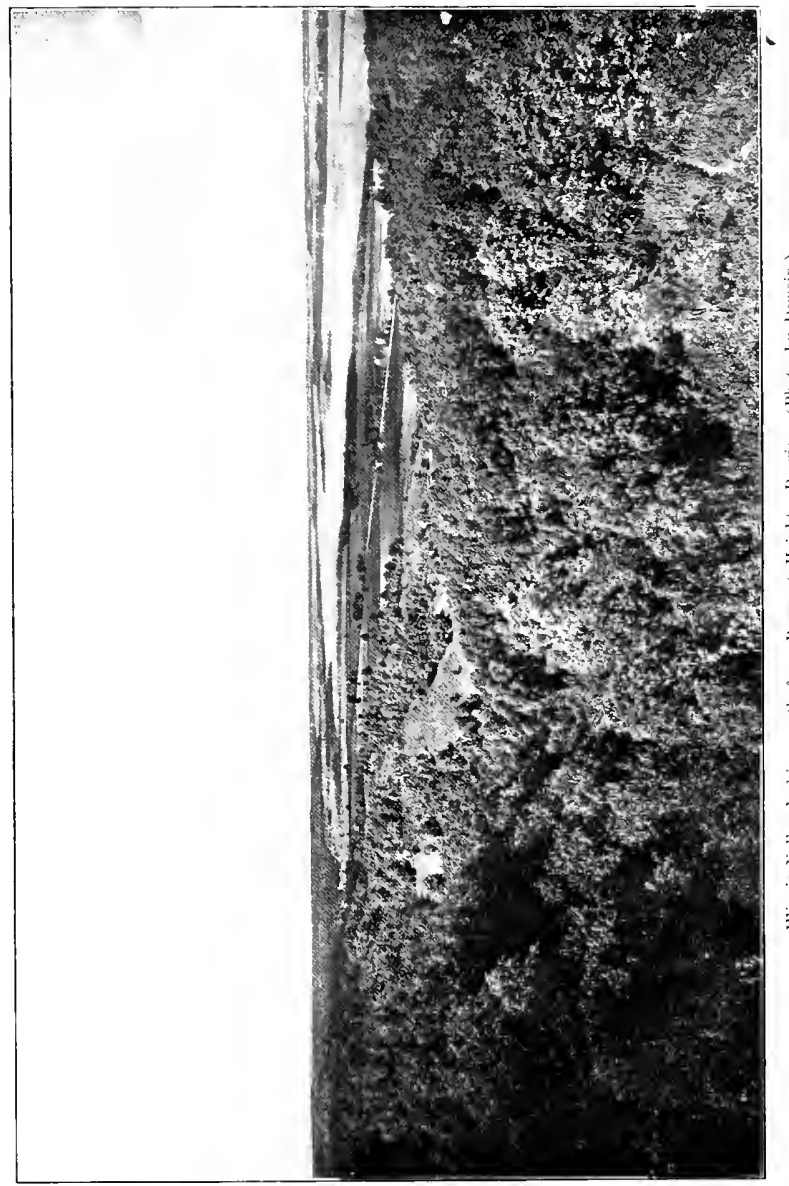




\title{
GEOGRAPHY OF THE MIDDLE ILLINOIS VALLEY.
}

\author{
(By Hantas 11. Rumows, )
}

("HAPTER I

\section{THE PHYSIOGRAPHIC FEATURES OF THE REGION.}

The area included in the report.-This report explains the principal geographic features of the Illinois valley and vicinity between Hennepin and Pekin, and discusses the influence of geographic conditions in the historical development of the region. The location of the principal places referred to in the text is shown on the index map, figure 1. In the preparation of the report earlier discussions of the region were freely drawn upon, particularly those of Leverett $^{1}$ and Cooley. ${ }^{2}$ The topographic maps of the area, published by the Lnited States ( reological Survey, should be used in connection with the report, and are indispensible for local field study. ${ }^{3}$

The Illinois basin and villey. The basin of Illinois River and its tributaries are shown in figure 2 . It is 32,081 square miles in extent, over one-half the size of the State. Illinois River is formed by the joining of Des Plaines and Kankakee rivers, some 45 miles southwest of Chicago. Flowing to the westward for 50 miles, it bends sharply to the south near Hennepin, and then to the southwest to Mississippi River, about 40 miles above St. Louis. The great bend at Hennepin is one of the striking features of the river, and divides it naturally into two sections, the upper and lower Illinois. The river is about 350 miles in length.

The valler of Illinois River is the most conspicuous topographic feature within the State, and stream and valley have influenced the historv and development of Illinois in important wavs. For these reasons, and because certain peculiarities of the lower Illinois render it unique among rivers, the region is one of particular interest.

Variable aridth of the valley.-The floor of the valley, within the area concerned, lies from 150 to 250 feet or more below the upland plain in which it is cut, and in most places is bordered by steep bluffs. Relatively narrow sections of the valley in the vicinity of Peoria,

\footnotetext{
Leverett, Frank, The lllinois Glacial Lobe: Monograph 38, U. S. Geol. Surv., 1899.

${ }^{2}$ Cooley, L. E., Lakes and Gulf Waterway.

3 The following mans cover the area under discussion: Hennepin, Lacon, Metamora, Dunlap, and Peoria. They cost 10 cents each, and may be ohtained from the Director, U. S. Geol. Surv., Washington, D. C.
} 
north and south of Lacon, and just above the great bend near Hennepin, alternate with far broader stretches. The minimum width is $1 \mathrm{~L} / 3$ miles, near the northern end of the city of Peoria; the maximum is over $71 / 2$ miles, in the vicinity of Chillicothe. This great and

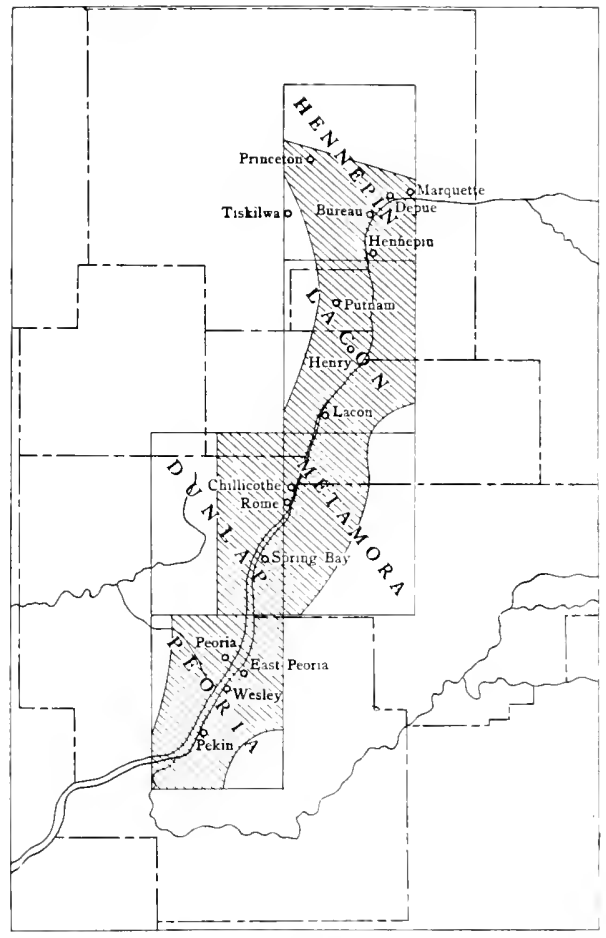

F1G. 1. Index map showing towns, quadrangles, and the area covered by thrs report

irregular variation in width puts the Illinois valley in striking contrast with most river valleys which wirlen somewhat regularly down stream.

The characteristics of the valley floor may be described under the headings (1) river and flood-plain, (2) alltvial fans, and (3) terraces (fig. 3). 
The river and its flood-plain.-The lower Illinois presents a second peculiarity in its remarkably gentle fall. Figure 4 shows the profile of the river, and figures 5,6, and 7 show, by way of contrast, the profile

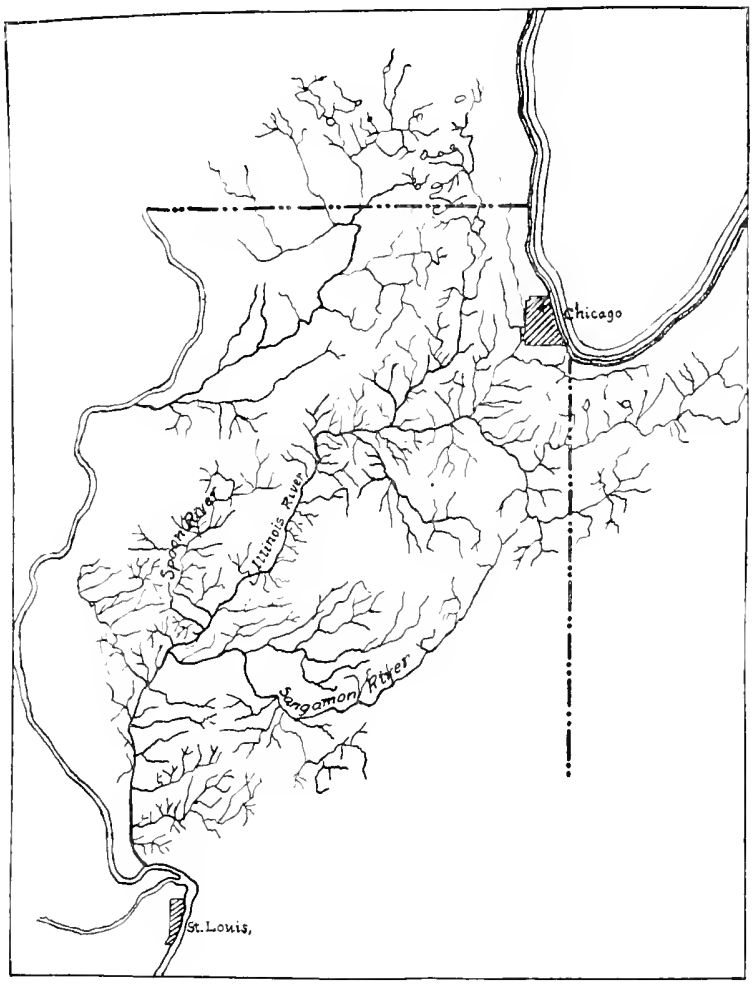

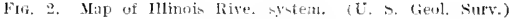

of Wabash River, a portion of that of the Ohio, and a section of the Mississippi, extending above and below the mouth of the Illinois. The 
low slope of the Illinois shown by the curve is perhaps more strikingly indicated in the following table prepared by Leverett, giving distances and rates of fall between Peru and Pekin.

\begin{tabular}{|c|c|c|}
\hline & $\begin{array}{r}\text { Distance- } \\
\text { Miles. }\end{array}$ & $\begin{array}{l}\text { Rate of fall- } \\
\text { Inches per nile. }\end{array}$ \\
\hline 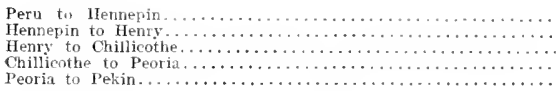 & $\begin{array}{l}13.6 \\
13.5 \\
13.3 \\
18.3 \\
10.7\end{array}$ & $\begin{array}{l}1.5 \\
1.07 \\
0.55 \\
0.26 \\
1.8\end{array}$ \\
\hline
\end{tabular}

The average fall between Hennepin and Pekin, a distance of 55.8 miles, is 0.82 inch per mile.

The Illinois is a river of relatively insignificant volume. Its natural low-water discharge (the lowest is about 500 cubic feet per second at LaSalle) is less than that of Rock River and but a small fraction of that of the upper Mississippi and Ohio rivers. The nearly level channel and the small volume result in a very sluggish river, which has been described as a stream that "more nearly resembles the Great Lakes, than an ordinary river," and again as one that "partakes more of the nature of an estuary than of a river." 1 It is unable to remove the sediment delivered by its headwaters and its numerous tributaries, many of which flow in steep-floored valleys. The deposition of this material has developed a number of the characteristic features of the valley, to be noted later. The lower Illinois is accordingly an excellent example of a depositing (aggrading) river. Deposition along its channel looks to the development of a grade sufficiently steep to permit the stream to carry away the material brought to it from the tributary uplands. Much grading must be done, however, before the present stream will have velocity sufficient to do this.

The inability of the river to maintain the present low grade means (1) that the existing gentle slope was developed by a river of larger volume than the present Illinois, (2) that much less material was formerly washed down from the uplands for transportation, or (3) that both these conditions formerly obtained. While the development of agriculture in the vicinity of the valley has doubtless increased the slope wash later considerations will show that the valley was once occupied by a vastly greater river.

Referring again to figures 4 and 7 , it will be noted that the average fall of the lower Illinois is less than that of the Mississippi below the mouth of the Illinois. This is the reverse of the normal relation between tributaries and their main streams.

Although ordinarily of relatively small volume, the lower Illinois is sometimes greatly swollen by the melting of snows and by rains (the natural flood discharge reaches about 85,000 cubic feet per second at LaSalle). Large areas of bottom land are then submerged, the valley

${ }^{1}$ A]though these descriptions were written before water from Lake Michigan was turned into the Illinois through the Chicago Drainage Canal, they remain substantially true. 


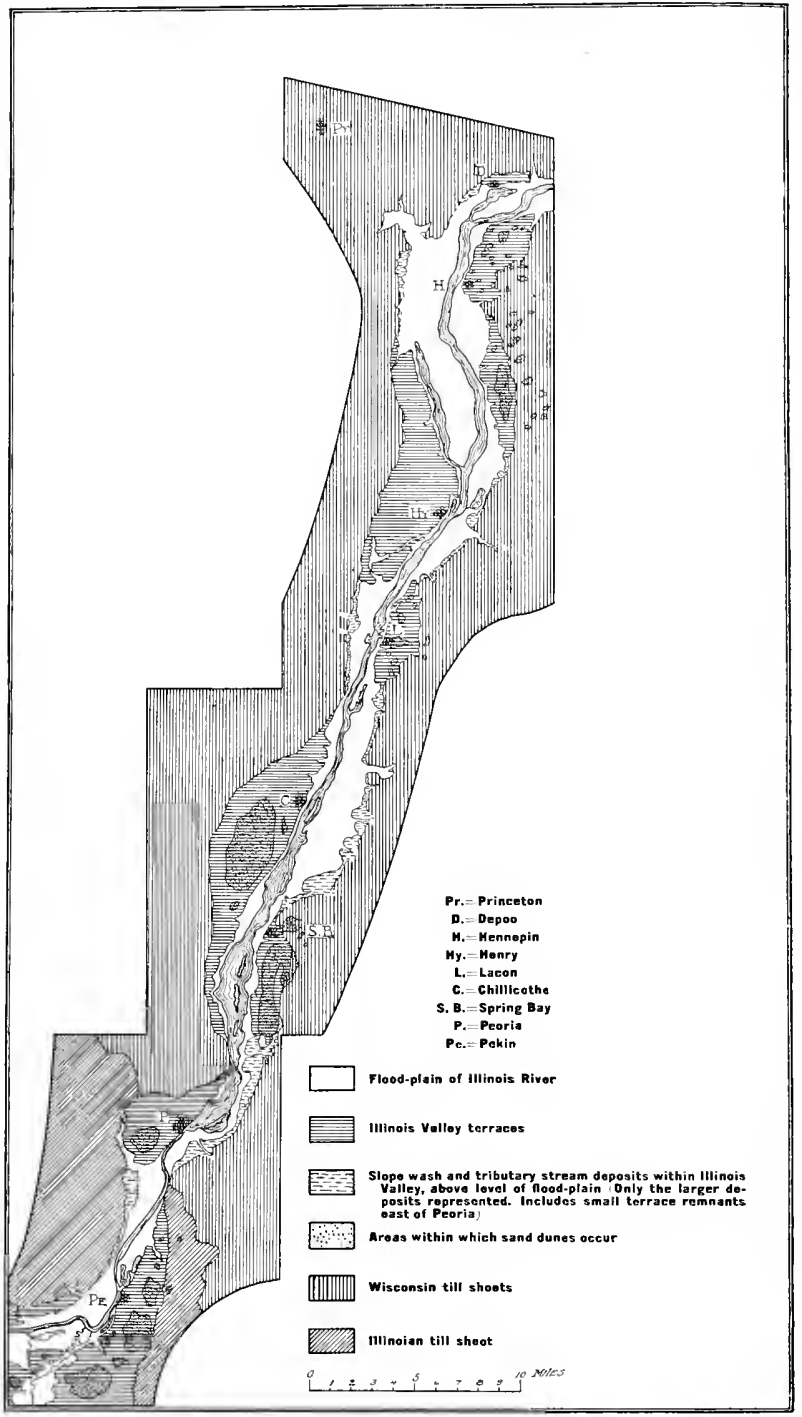

Fio. 3. Map showing general distribution of certain leading features of the region. 
presenting the appearance of a great lake. The portion of the valley botton subject to overflow, the flood-ploin, borders the river as an irregular strip, rarying from alout one-half to tis miles in width (fig. 3). The area of the lood-plain letween Ltica and Feoria is 113.5 square miles.

During overflow the river deposits most actively along the margins of the channel where the lepth of the overflowing water is surtenly liminished. and, in comseguence, its velocity and carrying power. Here luring the continuance of the overflow, the narginal waters of the main current are checked by friction with the less rapidy moving back-waters. Deposition along these lines during successive overflows tends to build low marginal ridges with a gentle from-river slope. Such emlankments are called nutural lea'e's (fig. S).

The natural levees along this portion of the Illinois have been built scarcely more than half up to floor level, a further evidence of the river's lack of arliustment in present conditions. In general, they are best developed below the mouth of tributaries which contribute much sediment. It is eviclent that natural levees will not prevent subsequent overflow, since the river can build them only to the level of its food waters. Artificial embankments have been built upon the natural levees of many agrrading rivers in order to reclaim their bottom lands. It is sail that to be effective such levees along Illinois River would have to extend 12 fect above the present banks. Only in this way can extensive fertile tracts, now nearly worthless, be reclained.

The overloaded contition of the Jllinois is further shown by the sand bars and islands that have accumnlated along its channel, expecially off the mouths of certain trilutaries, such as Bureau, Crow, and Kickapoo creeks. Since such shoals inhibit navigation, attempts were marle to overcome them by drelging as early as 1852 and large sums were subsequently expeniled.

Only a small fraction of the flood-plain which includes the higher ground built up ly the leposits of tributaries and by wash from the valley walls, is at present cultivalile. The lower areas are an unoccupied waste of marshes, lakes, punds, anil sloughs, which it was formerly thought must "ever remain upinhabited." Dike roads, maintaines at considerable expense, leach across these areas from the principal towns. The lakes range in size from mere ponds, to large bodies as Lake Senachwine (fig. !) wer + miles in length, which so strikingly resenbles a section of the present river as to plainly suggest its origin. They are being gradually ibliterated (1) by the encroachment of marsh vegetation upon their shallow horlers, (2) by wash from their surroundings, and (3) hy wind-blown material. Like lakes of other classes, they are therefore temporary features.

The materials of the flood plain range from gravel to the finest silt. The coarser material dropped by the river is in general confined to the borders of the channel. where, as noted above, the velocity of the overflow is promptly checked. This coarser material srades more or less 
BARBOWS.]

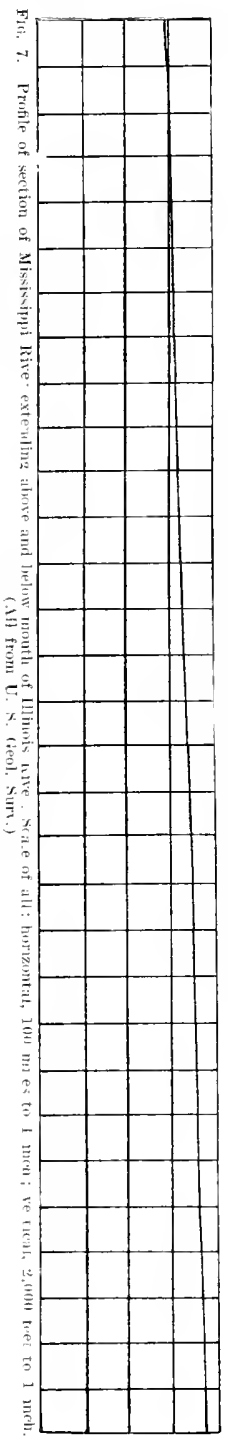

PHYSIOGRAPHIC FEATURES.

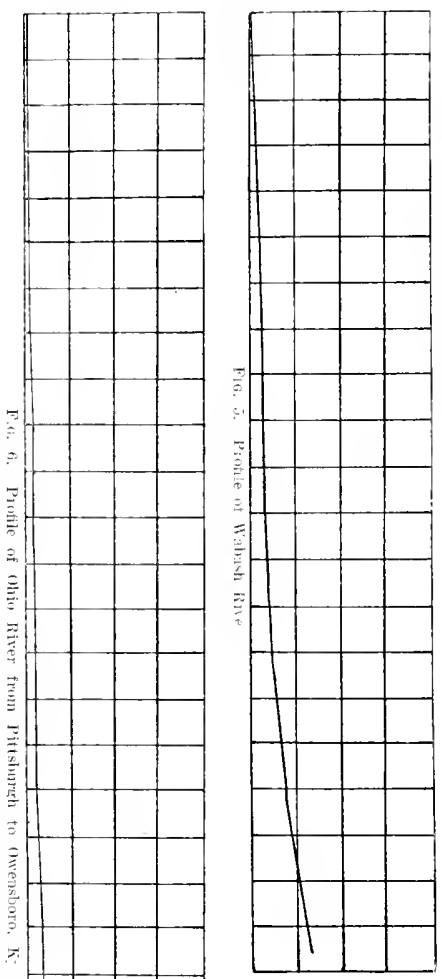

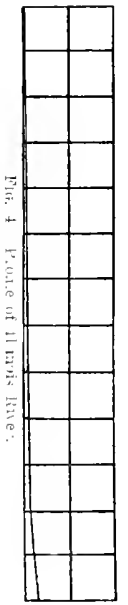


irregularly into the fine muds which gather in the quiet backwaters. In certain of the marshes, for example opposite Chillicothe, the dead leaves, twigs, and branches of the swamp vegetation gather in the shallow water, along with minor quantities of silt. This vegetal matter, preserved by the water from complete decay, is being slowly transformed into peat, which in the future may have economic value. Further complexity in the distribution of the materials of the flood-plain is introduced by irregular contributions made by bluff wash and by tributary streams.

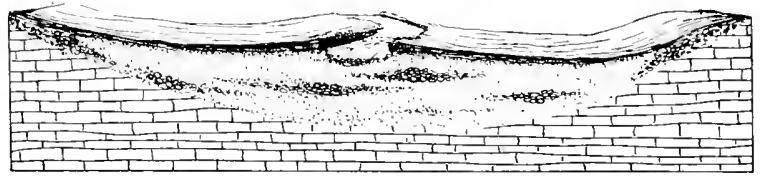

Fri. 8. Dingram showing natural levees.

Should the river change its position on its valley floor, the coarser deposits along the new channel would cover finer deposits that had been made at a distance from the old channel. whose coarser material would in turn be buried with fine. Frequent changes in position by the aggrading river would result in many vertical alternations in coarseness. Minor variations would be invited by the unequal strength of the overflow capable of moving particles of varving size to a given place at different times. Borings in the flood-plain of the Illinois disclose pronounced variations in material, and point to many earlier changes in the position of the river, as the lakes do to recent ones. A typical succession is revealed by the Peoria city well ( 47 feet deep), located upon the flood-plain, which penetrates the following beds, beginning with the lowermost: (1) sand and clay, (2) fine gravel, (3) clay, (4) coarse gravel, (5) clay, and (6) shells, sand and gravel.

Such shiftings as here recorded are common to aggrading streams. Figure 10 shows the resulting general structure of stream deposits. The present position of the river in its valley is determined by its tributaries in a manner described below.

Alluvial fans.-Practically every tributary valley of the Illinois within the area covered by the report is fronted by deposits made by its stream. Because they are half-circular in ground plan when typically developed, and because they are composed of alluvial material, deposits of this class are called allivial fans (Pl. I, A). Generally speaking, alluvial fans are best developed at the bases of steep slopes in arid regions where streams of diminishing volume leave the relatively high gradients of their mountain valleys to enter lowlands. Their extensive development along the middle Illinois shown on the Peoria and Metamora topographic sheets, is a further peculiarity of this. remarkable valley.

The smaller fans east of Peoria Lake and in other sections of the valley, maise many uneven roads at the foot of the bluffs, and since the 


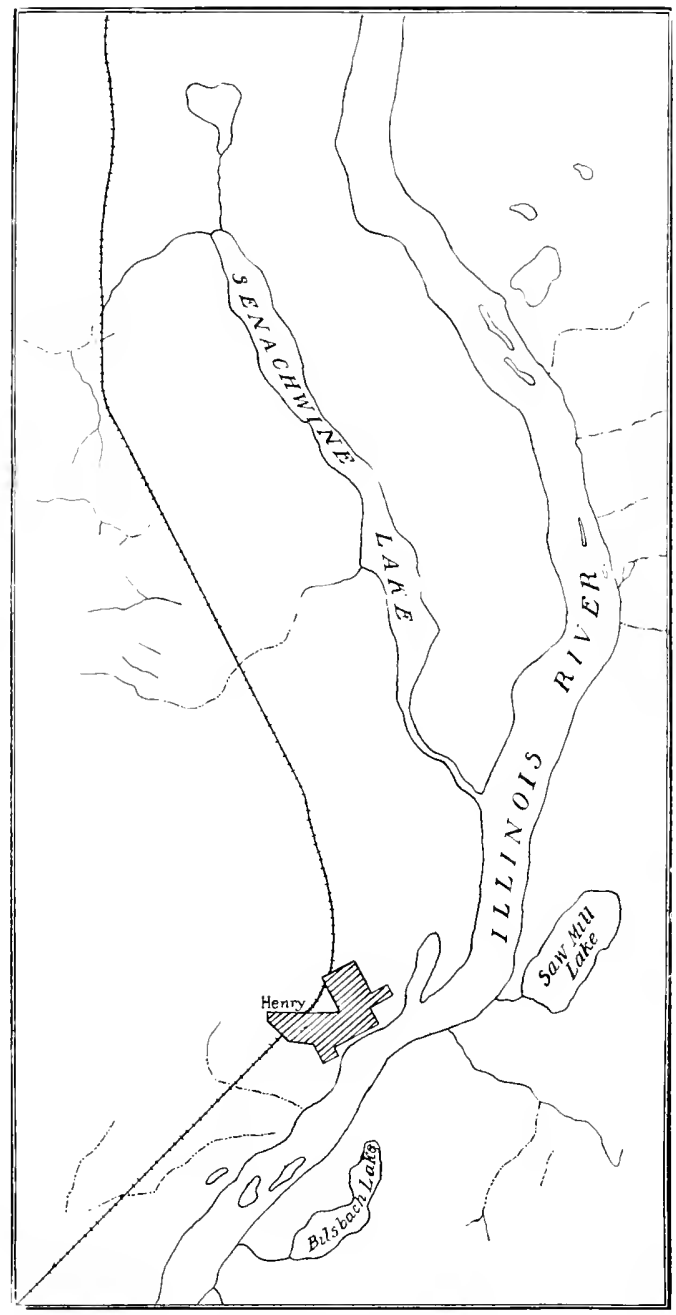

Fig. 9. Map showing lakes on Illinois River flood-pluin near Henry. (From Lacon topographic map, U. S. Geol. Surv.) 
fans are higher than the adjacent bottoms, they have frequently been selected as sites for homes. The larger tributaries, such as Fat in and Ten-Mile creeks, have built exten-ive fans of very gentle slope. Farm creek fan, opposite Peoria (I\%, 1]), affords an abtudance of lanc favorably situated for the growing manufactures of the cits. The fans of the larger tributaries divide the bottom lands into more or less istinct sections, and help to maintain the marshiness of the lower tracts. Furthemore, these deposits determine the position of Illinois: Kiver on its flowl-plain in many places. Thus the leposits of Bureau creek force the river against the Hennepin bank. Sandy Creek, How

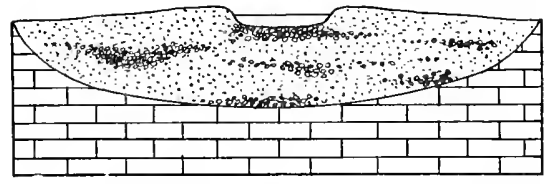

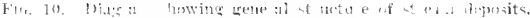

ing from the east. helps to keep it alomg the western edge of the flood plain at Henry. The tributaries opposite Chillicothe accomplish a similar result. The lare fan of Ten-Mile Creek crowds the river against the westem hluff at the "Narrow's" north of Peoria, scarcely leaving room at its base for the wagon road and railload which rum morth from the cits. Farm Creek fan is resmmsille for the position of the river along the western side of its flood-plain at Peoria (Pl.II). while the deposits of Kickapon Creck just to the south carry it abrupt!: over the easterin sile of the valler at IVesley. The deposits of Lamarsh Creck and Mackinaw kiver control its course farther south, pushing it in each case toward the opposite side of the ford-plain. The helpless manner in which the river wanders around the deposits of its trib taries was commented upon some years ago ly L. E. Cooley of the Chicago Drainage Commission, who pointerl ont that it was found on the side of the valley opposite the tributary whence the deposits came, and that in general its location marked a nentral line indicating the relative contrilution from either side.

Igain, the reposits of certain tributaries greatly affect the wirth of the Illinois. The fan of Farm Creek acts as a dam, producing the wide expansion of the river known ns Penta Lata (Pl. II). Above the "Narrows" at the fan of Ten-Nile Creek is another hroad expanse, 1. miles wirle at one point, called the Upper Lake. The river has several times its ordinary width extending nearly to (hillicothe, to which point Peoria Lake is frequently considered. Pelow Peoria Lake the deposits of tributaries have male the river unusually narow for some miles, and have built the flond-plain above its average height. 


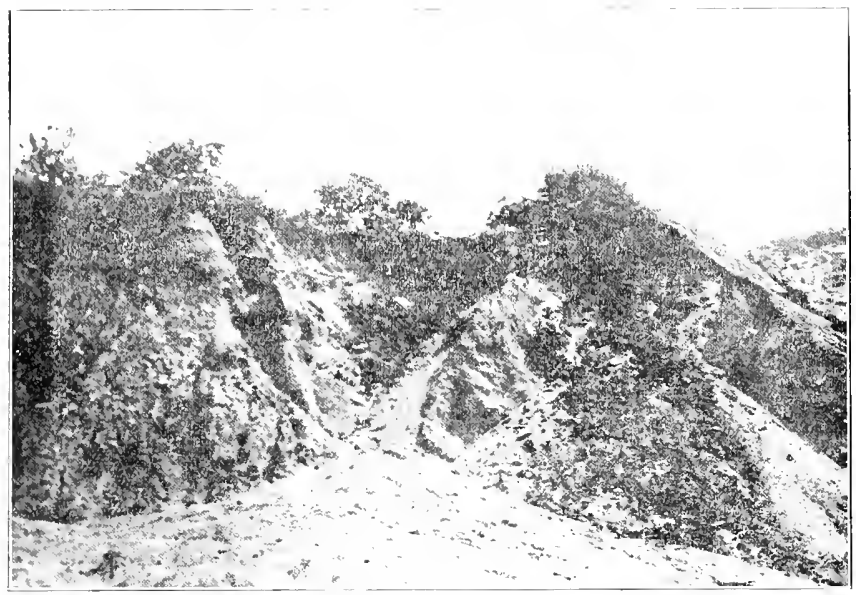

1. 1 vet:11 , Ifltwi,a] fint.

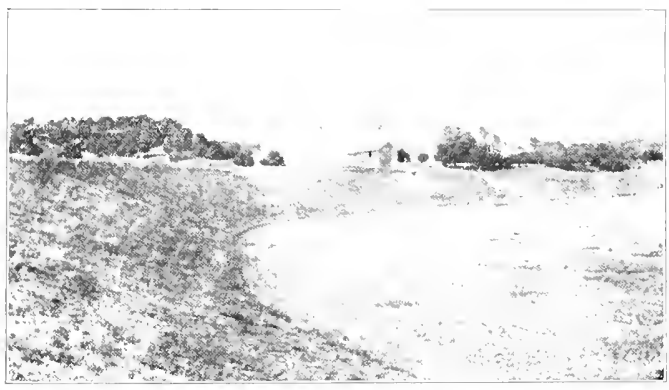

B. A small terace in valley of $\mathrm{r}^{2}$ am Creek. 

The very low slope of the Illinois flood-plain, together with the flatfans of the large tributaries, accounts for the unusual course taken by some of the streams after they enter the main valley. Tributary streams on entering large valleys commonly flow greater or lesser dis. tances down valley before joining their mains, with which they usually form acute angles up-stream. In contrast, some of the larger tributaries of the middle Illinois River take very irregular courses within the main valley and in a few cases flow some distance up-stream before joining the main river.

Terraces.-In common with certain other valleys of the northern part of the United States, the valley of the middle Illinois is characterized by a series of extensive flats at varying heights above the flood-plain. Such flats above flood-plains are terraces. The frontispiece and Plate III show portions of the terraces of Illinois Valley north of Peoria, and Plate I, B shows a small terrace in the valley of Farm Creek, near East Peoria. Figure 11 shows a flood-plain, terrace, and upland, and indicates their relation to one another.

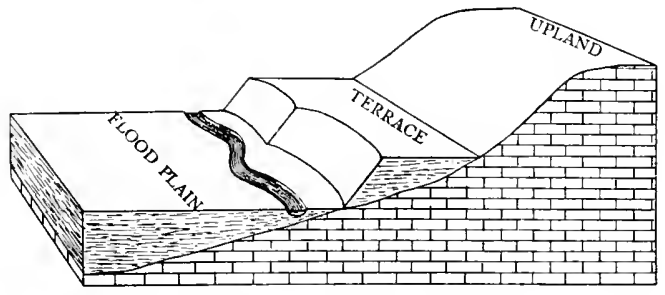

Frg. 11. Diagram to show the relation of a food plain, terrace, and urland to one another.

The terraces are composed principally of sand and gravel of varying degrees of coarseness whose structure may be observed at numerous sand and gravel pits, and other exposures. The material is in layers, and therefore water-laid. Layers of fine and coarse material alternate frequently, showing that the velocity of the depositing waters changed often at a given place. Traced horizontally, layers thin out and give place to others of different composition; hence the character of the depositing waters varied from point to point at a given time. The thin divisions within layers (laminae) slant in various directions, and meet each other at varying angles; hence the material was deposited upon an uneven bottom by irregular currents. The deposits of the present flood-plain (pp. 6-8) have the general structure of these terrace beds, and are forming under conditions similar to those under which the material of the terraces was deposited. We therefore conclude that the terrace beds are those of ancient flood-plains, at whose level the river once flowed. From this it follows that the highest terrace is oldest, and that the terraces are successively younger as the present flood- 
plain is approached. Since the terraces are remmants of old flood-plains, they are remmants of flats which originally extended across the valley to the edge of some higher ierrace or to the valley wall. Since floodplains decline lumin-stream, a given terrace should stand at progressively lower levels lown vallev.

The terraces are in striking contrast with the present flood-phain, in that ther are in many places male uneven by sand hills built upon them and by shallow, steep-sided valleys cut into them. Sand hills are especially well developed on the Chillicothe and Pekin terraces. Here they fom a complex of irregularly shaped hills and short rider of often assiciated with shallow depressions withunt outlet. In some instances they attain an elevation of 30 to to feet or more above their immetiate surrotumlings. Since the terraces were originally flum-plains, these features were ofwiously acouired since their formation.

The terrace gravels are extensively used on wagon roads and for railroal ballast. The Atchison. Topela anel Santa Fé Railwas Company ships gravel from its large pit at Chillicuthe to all points along its road from Chicago to western Mlissomi. There are railroal pits also at or neat Bureau. Hennepin, Henry, and Pelin. Since central Illinois has hut limited supplies of good mad material, these terrace gravels are likely to find a wirle market in the future.

The terrace sils are generally sandy loams, though clay soils are not wantine, especially neat the bluffs, where there has been more or less wash from the uplands since the terraces were formed.

Every important toun of this part of the valley srew up upon a terrace, awiding alike the bottums that are subject to floods, and the mplands that are usmally 150 feet or more abuve the waterway. The early relations of the villages to the river are reflected in the fact that the streets in the older quarters run parallel to the river front and at right anglen to it, rather than with the points of the compass. The immediate location upon the terrace edge was in several cases determiner hr relatively large tributary streans on the opposite side of the valley, whose deposit crowled the river to the terrace side of its foom-plain. Pekin and Peoria appear to be striking illustrations of this control. Peoria has spread from its lower terraces to an upper one, and is now spreading back upon the tppland.

The bluffs.-The hluffs which bound Illinois Valles vary considerably in height, reaching a maximum as already indicated, of over 250 fect. Their height is intuenced by the varying altitude of the upland and the nature of the surface to which they descend. Where they separate the more elevated tracts of upland from the flood-plain. they are relatively high: where they intervene between the lower uplands and the terraces, they are relatively low.

The hluffs of the mirllle lllinots are commonly too steen for cultiration and remain wooled. The frontispiece and Flate III show their typical character. Their steepness indicates that a vers short period, as geology measures time. has elapsed since the river, flowing at their hase, undercut them and male them steep. In this moist climate, so much material would otherwise have washerl from the upper slopes, lodging at the base, as to greatly reduce their steepness (fig. 12). This 


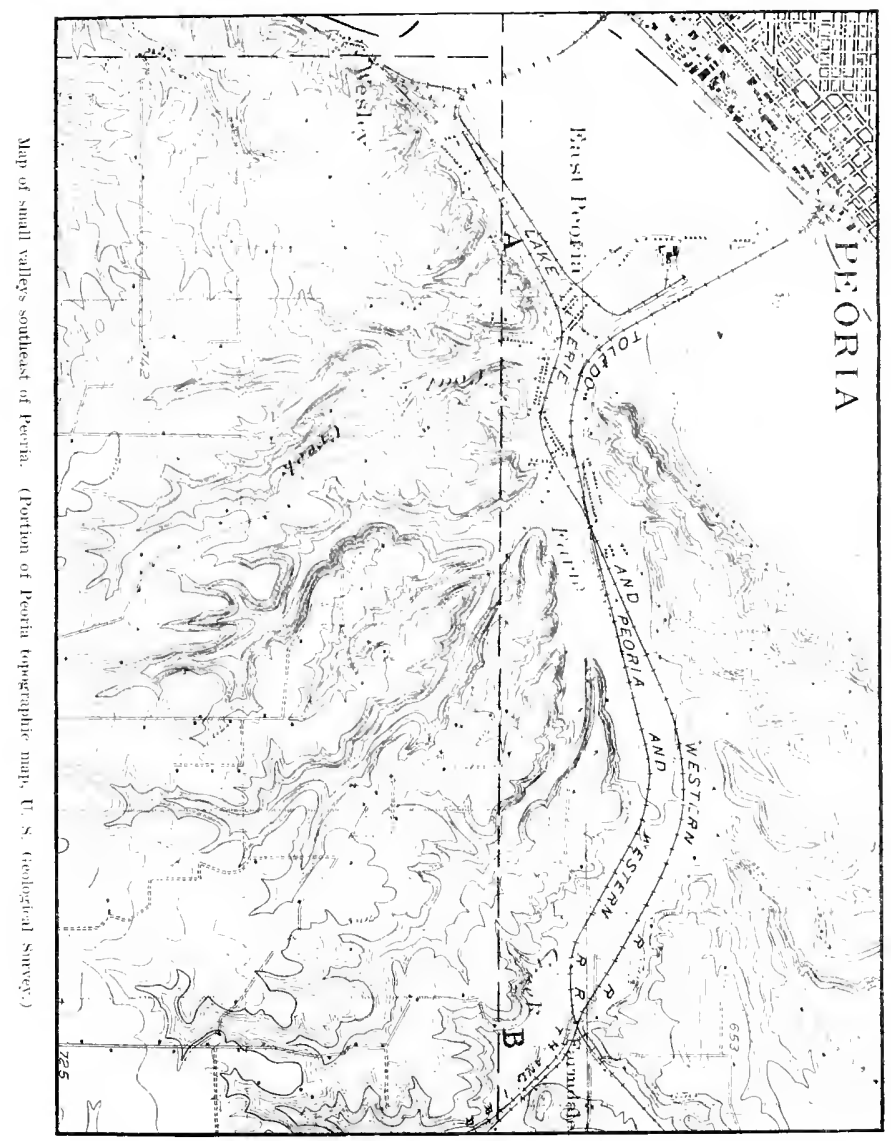



is especially true since the bluffs of the Illinois, within the area with which this report is concerned, are almost exclusively of clay, sand, and gravel, rather than firm rock. Locally the bluffs have much less than

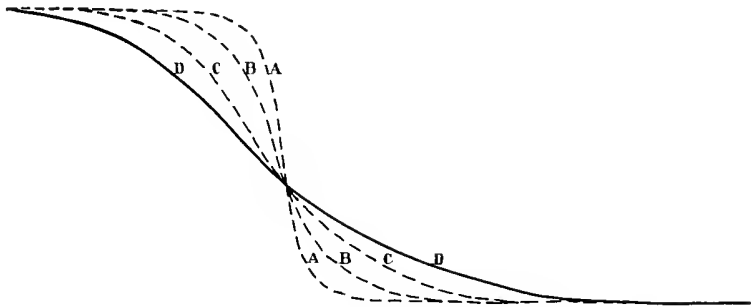

Fig. 12. Diagram to illustrate the reduction of a bluff by slope wash. Successive profiles are indicated by the letters.

their customary steepness, and since their composition is essentially the same as where steeper, we conclude that such sections have been free from undercutting for a longer time. Plate IV, A shows low bluffs of gentle slope north of Bureau, and Plate IV, B shows the curve, concave upwards, which slope wash tends to produce.

Roads from the upland seek the valley bottom at infrequent intervals, often taking advantage of the floor of some of the larger ravines which trench the bluffs. The easier grades of the larger tributary valleys have located the railroads which traverse the region. The main line of the Chicago, Rock Island, and Pacific Railroad leaves Illinois Valley at the great bend along the valley of Big Pureat Creek. Crow Creek, opposite Chillicothe, affords the Atchison, Topeka, and Santa Fé Railroad an easy descent to the Illinois flood-plain. The valleys of Farm Creek and Kickapoo Creek, on opposite sides of the river at Peoria, are utilized by railroads leading to that city from the east and west.

The general valley features thus far described, are shown in figure 13 , a cross section of Illinois Valley at Peoria.

The upland.-The upland plain has a general elevation of 650 to 700 feet above sea level to the north of Peoria and of 600 to 650 feet to the south within the area considered here.

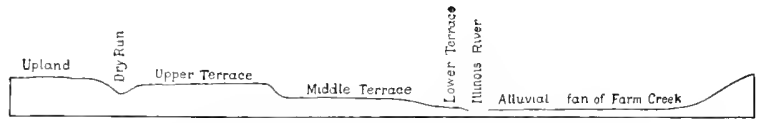

FIg. 13. Cross section of lllinois Valley at Peoria.

Vertical scale: 200 feet to 1 inch; horizontal, $1 / 2$ mile to $1 \mathrm{inch}$.

The otherwise flattish topography of the uplands is broken (1) by the numerous small valleys which border the Illinois, and (2) by certain low, broad clay bridges unrelated to valleys. 
The small zalleys.-Small tributary valleys and ravines border Illinois Valley on either sicle. They are frequently separated only by narrow tongues of upland, so that the surface is largely slope. This fact is brought out by Plate II, which shows numerous small valleys east of Peoria by means of conturus, and by figure 14 , which represents the character of the surface between the points " $A$ " and " $B$ " on the map. Throughout the area under consideration the valleys tributary to Illinois V alley (as in the case of those shown in Pl. II) are generally narrow and steep sided. They commonly have high gradients and many are without permanent streams. Nlthough the great majority of these valleys are only a fraction of a mile in length, the dissected belt north of I'eoria extends 2 to 5 miles from Illinois Valier, and it is considerably wirler than that to the south of Peoria. Still farther back from the llinois, the small valleys are less numerous and deep, and the upland surface therefore more regular.

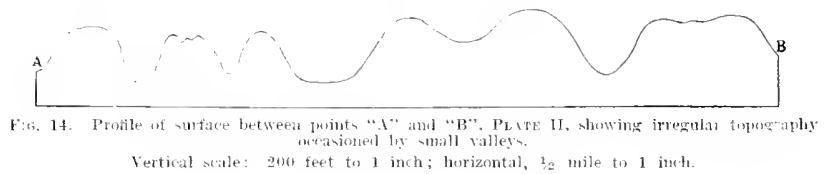

Those uplands from which the bluffs of Illinois Talley descend directly to the flood-plain are more rugged than the uplands which are adjacent to the terraces, for the valleys leading back from the thoodplain level are deepre than those which extend inland from the terraces.

Further characteristics of the small valleys may best be pointed out in connection with the tiscussion of their origin (p. 56). The great discrepancy in size between Illino is Valley and its trilutary valleys should be noted, however, as again putting this valley system in con trast with normal valley systems.

The clay ridges. - The general distribution of these ridges, under the name of moraines, is shown in figure 20 . They extend, with varying characteristics, far beyond the area under discussion, as members of a complex series of ridges and hilly helts, which rudely encircles the head of Lake Michigan. In the area lescribed here they commonly exceed 2 miles in width, and are locally a conspicuous feature of the landscape when viewed from the plain th the west of them. Near Groveland the ridge exceeds 590 feet in elevation, rising 140 to 150 feet above the plain which borders it 2 miles to the westward. The ridge extending northward from North Peoria is also well developed, its proximity to Illinois Valley accounting for the shortness of the ravines tributary thereto on the west. in comparison to those on the opposite side of the valley.

In the area under consideration, the surface of these ridges is usually rather regular, though always lacking the even crest popularly associated with the term. Locally, as near Groveland, their surface is diver- 


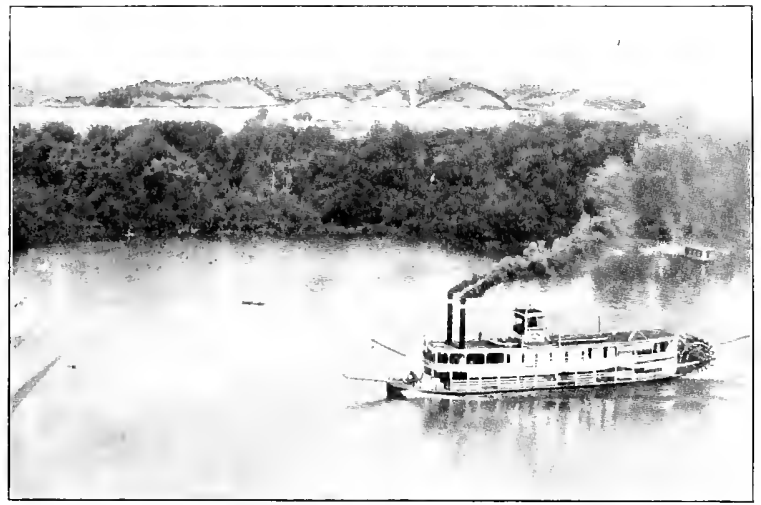

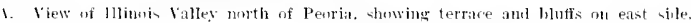
(Photo by Trewein.)

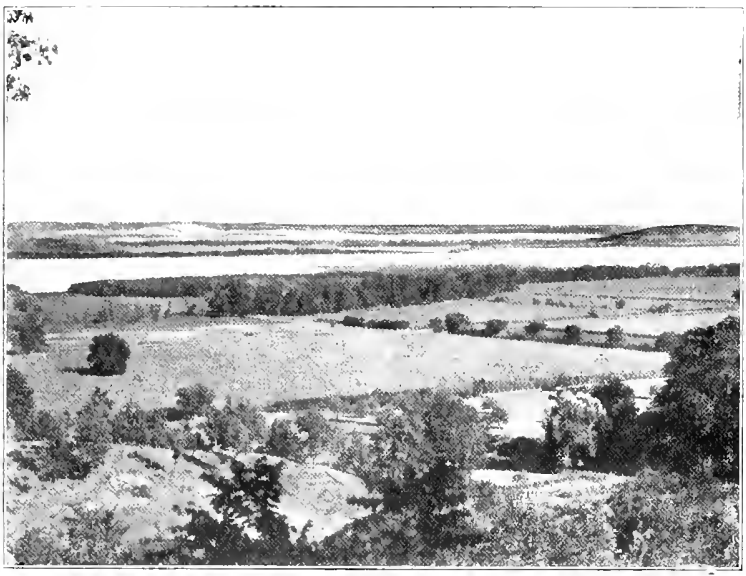

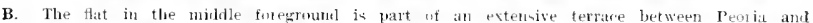

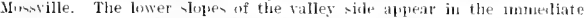
finerrouml. (Photo by lessin,) 

sified by mounds and hillocks, sometines associated with shallow, undrained depressions. Beneath a surface coating of brown silt, they consist of moderately stony clay.

The clay ridges stand in no definite relation to drainage lines and are therefore not remnants of once continuous uplands, whose surroundings have been worn lower by streams. Nor could the shallow basins which locally interrupt their surface have been formed by running water, since all strean valleys possess outlets. The special conditions under which these and other important features of the area developed. are considered in Chapter III.

Summary.-The more important general features of the region are the following: (1) A great valley of very irregular width, lying 150 to 250 feet below the upland plain, from which steep bluffs descend. (2) An aggrading river of extremely gentle fall, which flows sluggishly around the deposits of its tributaries, by which it is locally expanded to the dimensions of a lake. (3) An extensive flood-plain whose marshes and lakes withlold large areas from agriculture. The surface of the flood-plain rises very slightly along the river to form imperfect levees, and las been built above its normal level in places by the deposits of tributary streans and by rain wash from the valley sides. (4) A remarkable series of alluvial fans, by which the tributaries assist in filling Iflinois Valley. (5) A system of extensive sand and gravel terraces. The surfaces of the terraces, originally nearly flat, are now diversified locally by sand hills and by small valleys. They have located the towns and cities of the region. (6) A flattish upland plain, deeply dissected by small valleys in the vicinity of the Illinois, and traversed by morainic ridges.

The history of the development of these features is traced in subsequent pages. 


\section{CHAPTER II.}

\section{THE BED KUCKS OF THE REGION.}

Distribution of outcrops. - bed rocks in definite layers are exposed (outcrop) along certain stream bottoms and valley sides within the area under discussion. They may be studied to advantage along the course of Kickapoo Creek and several of its tributaries, at points along Lamarsh Creek, opposite Pekin, and in the valleys of Gimlet and Thenius creeks, near Sparland, all on the west side of the Illinois, and in the vicinity of Wesley on the east sicle. There are small exposures also in the ravines about 2 miles north of Chillicothe, along Rowe's Hollow. southwest of Henry, and near Marquette. Bed rock is not known to outcrop on the western side of fllinois Valley between Henry and Marquette, nor on the eastern side letween East Peoria and a point some miles berond Hennepin.

The above ontcrops are the edges of essentially horizontal rock layers, some of which extend back beneath the uplands considerable distances. Very similar formations underlie the entire region with which this report is concened, and extend far besond it throughout much of the State. They belong to a great system of rocks known as the Pennsylvanian (Carboniferous) system, formed during the Pennsylvanian perionl.

Influence on topoyrophy.- Where exposed in valley sides, the bed rocks sometimes occasion nearly vertical slopes (I']. V), alihough they form no striking scenic features, and in general exert little influence upon the topography. Porings show them to be commonly covered by 200 to 300 , and sometimes by 400 to 500 feet of clay, sand, and gravet.

Economic importunce-The principal ontcropping rockis are shale, sandstone, limestone, and coal of which all are of more or less economic value. Shale in quarried at several places south of East Peoria, for the making of tile and brick. Sandstone and limestone have been quarried locall! for building purposes, and the latter for the manufacture of lime. Coal is the greatest mineral resource of Illinois. The output more than loubled in the decade 1895-1905. and in the rear 1908 harl a value of nearly $\$ 50,000,000$. Four counties bordering on the middle Illinois River (Bureau, Peoria, Marshall, and Tazewell) furnisherl ahout one-twelfth of the total. The increase in production during 


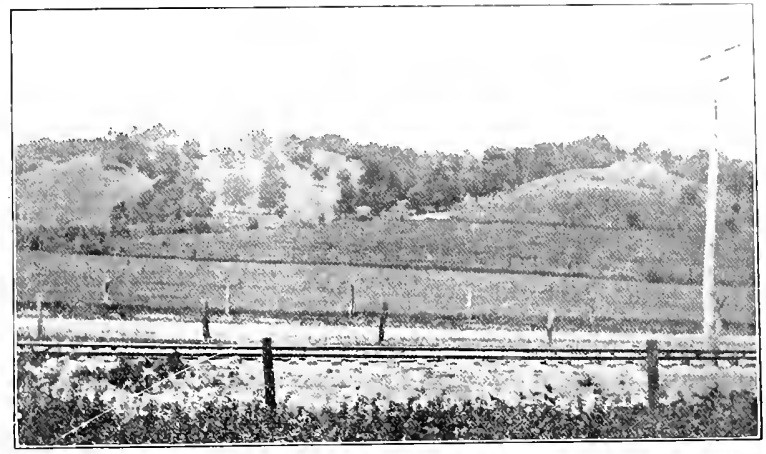

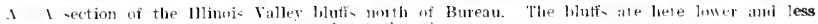
justintint thim in tommons.

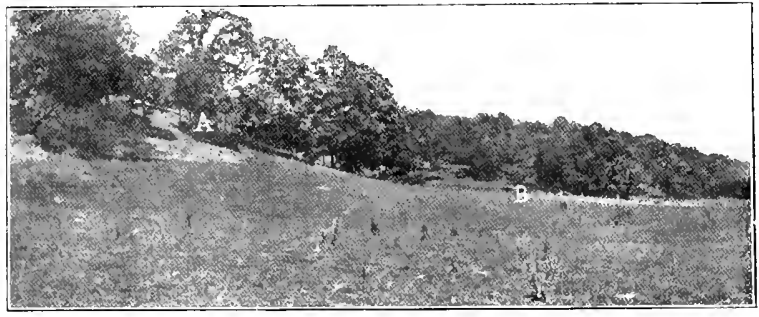

B. Lower valley side north of Bureau. The slope between "I" and "B" show the deqmitional protile formed by raili wish. 

the next decade or two is generally expected to be even greater than that of the past decade, and the industry appears to have an especially bright futute along Illinois River, destined to be one of the great commercial highways of the workl, when it becomes a link in the projected line of deep water navigation between Lake Michigan and the Gulf of Mexico (p. 121).

Such economic considerations make the coal bearing rocks of the middle Illinois Valley, together with the conditions of their formation, of special interest.

Characteristics and origin of the sandsionc.-Sandstone forms precipitous bluffs 15 to 30 feet high at many points along the lower course of Kickapoo Creek. Examination shows that the sandstone consists chiefly of medium sized sand grains bound together by a cement of calcium carbonate or iron oxide. The latter cement determines the brown color of much of the rock. Some of the more ponty cemented sandstone may be readily pulverized, when it resembles in all respects the finer sand accumulating along the flood-plain of the neighboring creek. The sandstone is in massive, nearly horizontal layers, some of them 5 feet or more in thickness. Thinner divisions (laminac) slanting in different directions, and meeting each other at various angles are conspicuous within certain layers. Rocks affected by such oblique laminat are said to be cross-bedded.

The foregoing characteristics of the sandstone throw some light on the geography of the environs of Peoria at the time the sand was deposited. The fact that the rock is in lavers signifies that the sand was accumulated in water, to which it was brought largely by streams from the land of the time. The further fact that only sands were deposited here for some considerable time implies that the bottom waters were in sufficient agitation to prevent any muds that were washed down from the land coming permanently to rest. This means that the water was shallow, for waters are commonly stirred by waves, currents, and undertow, only to comparatively slight depths. That the water was shallow is further proved by the cross-bedding of the sandstone. This structure is developed only along stream bottoms and off ocean and lake shores, where the depth is sufficiently slight for the bottom water to be in frequent agitation. The cement by which the the loose sand was bound into firm sandstone was deposited from solution in percolating waters. Certain inferences may also be made concerning the land whence the materials of the sandstone came. It must have possessed at least moderate relief, for the streams of very low, flat lands are too sluggish to transport sand in quantity. Its rocks must have been of a kind whose lecay would yiekl sand. It need not have been, and probably was not, close at hand, for sediment may be rolled and dragged long distances along a shallow bottom before reaching a final resting place.

The sandstone formation just considered is not known to have extended throughout the area here considered. Varying depths of water or unequally strong waves and currents may have caused the accumulation at the same time of different materials in other nearby localities. 
The shale and its formation, - Shate is the most common rock in the region. It consists of mud particles pressecl and cemented into a compact mass. Fresh surfaces are generally blue or green in color. though locally an abundance of carbonaceous material rencles the shale nearty or quite black. Upon long exposure it becomes yellow in consequence of the oxirlation of its irom. The shale is commonly in thin lavers, many of them but a snall fraction of an inch in thickness in which thin bands and roundish masses of ironstone are locally inclucled.

The several shate formations exposed in the area were probably formed under substantially the same conditions. As in the case of the sandstone, the fact that the shale is in layers indicates that the nuts from which it was derived were deposited in water. Shale further re quires water sufficiently quiet to permit fune sift to remain upon the bottom.

The limestone.-Limestone is much less abundlantly exposed within the area than sandstone or shale. Occasional outcrops range in thickness from a few inclues to 5 feet, and in appearance from a dark gray, fine-grained rock to a very light colored, cristalline one. The beginning student will be helperl in the identification of limestone by the fact that when it is treated with lydrochloric acid, a bubbling or efferrescence is produced. Certain of these limestones contain many recognizable relics (fossils) of marine animals, and are doubtless made up chiefly of organic remains. These fossils prove that when the limy material now compacted into firm rock was deposited, the sea covered the area where the limestone occurs. Furthermore, since the limestone contains little sandy or claver material, it is evident either that the areas of accumulation were some distance from shore, heyond the reach of land-(lerived sediment, or that the neighboring land was so low that its sluggish streams were umable to wash material in any amount to the sea. Certain limestones occur within the region, that lo not appear to contain fossils, and these may have been chemically precipitated from the waters of local basins or ocean embayments.

The coal.-Coal is the product of the partial decay and alteration of vegetation. Under the microscope it may in some cases appear to be a mass of altered vegetable matter. ${ }^{-1}$ It frequently contains abundant remains of plants. Tegetahle natter in various stages of change connects the coal by all gratations with the vegetation of present marshes. The coal plants grew where the coal now is. Had they grown elsewhere and been washed by streams to their present position, ther would have been mixed with much mud and sand. Great quantities of vegetable matter, essentially unmixed with sediment, are now forming only in bogs and swamps. It is therefore believed that each extensive coal seam along the midllle lllinois tells of a vast marsh in which the dead leaves, branches, and trunks of thousands of generations of trees together with their undergrowths, formed thick layers of vegetal matter. The marshes may have developed in inland basins, in lagoons along the sea shore, such as now occur ofl the coast of New Jersey, the Carolinas, and Georgia, or on river flood-plains. Indeed, the imperfect peat now

This does mot mean that a piece of coal under the microscope reveals it s veretil origin, but that coal properly treatel, and cut into sutficiently thin sertions will, in the hands of the expert, reveal its cellular structure. 


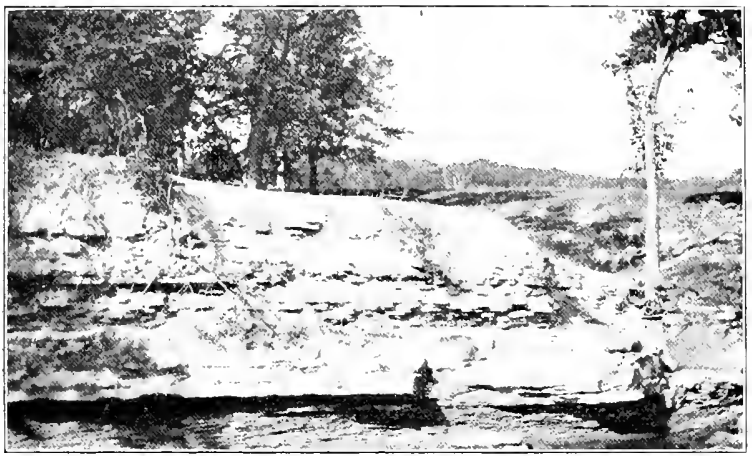

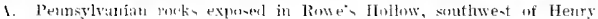

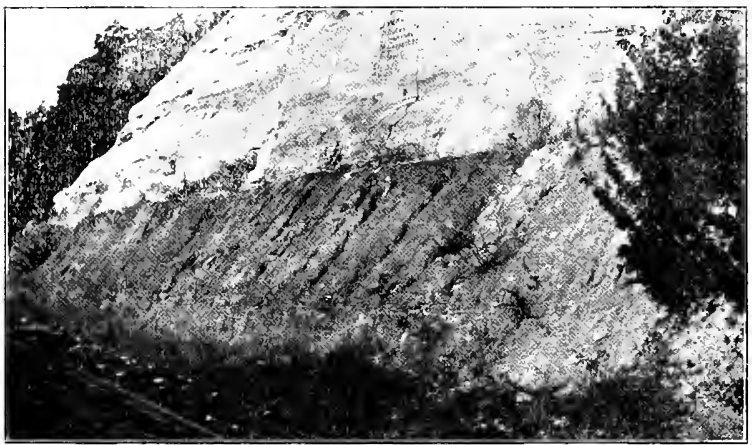

B. Exposme of Ptmnylvanian rocks in Kickapoo Valley, near Peoria. 

forming in parts of the Illinois flood-plain, for example opposite Chillicothe, represents the first step in the formation of coal. It is not probable that any one marsh extended throughout the coal producing area of Illinois, though individual marshes may have covered the entire area of the middle Illinois Valley.

Wood is composed chiefly of carbon, hydrogen, and oxygen. When it decays in the air, the carbon and hydrogen unite with the oxygen of the atmosphere and of the wood to form carbon dioxide and water. The other constituents are also disposed of by chemical combination. and the rood disappears. If the vegetation decays under water, however, it is protected from the atmosphere, and the elements of the wood unite with one another to a greater extent. The products of such decay withdraw the hydrogen and oxygen of the wood much faster than the carbon, which therefore makes up the lulk of the remaining mass. If this altered vegetation be buried under beds of sand or mul, further physical and chemical changes occur which help to produce coal. The conditions for the formation of coal are then abundant vegetation. protected by water from the oxygen of the atmosphere. These conditions are found only in such situations as those noted in the preceding paragraph.

Gcographic changes recorded by exposcd rocks.-The preceding paragraphs have indicated that each of the several kinds of rock exposed in the area originated under special and particular conditions. Since the strata alternate frequently, it is clear that many changes in physical geography occurred. The number. and something of the nature of these changes may be inferred from a study of the following typical section, which is exposed at Schmidt's mine on the west sicle of the lower Kickapoo. Number 1 is the lowest (oldest) of the exposed berls:

\begin{tabular}{|c|c|c|}
\hline & \multicolumn{2}{|c|}{ Thickneus } \\
\hline & Fent. & inchex. \\
\hline 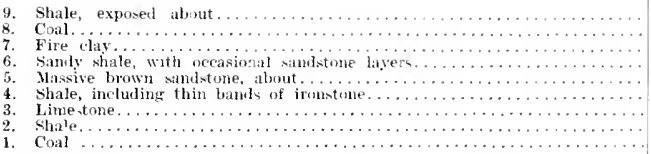 & 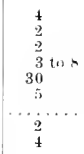 & 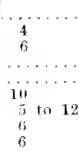 \\
\hline
\end{tabular}

The coal seam (No. 1) reprents the accumulation of marsh vegetation for a very long period. This was terminated by an inflow of water. due to the subsidence of the swamp or to a rise of the surface of a neighboring water hody. Fine muds (No.2) were next laid down upon a quiet bottom, burying the organic matter. The accu mulation of mud was succeeded by the formation of limestone (No. 3) when the land for some reason ceased to yield sediment, or its deposition was shifted to a new area. Renewed wash from the land or a shoaling of the water again allowed an influx of mud (No. 4). During this stage, iron that had been dissolved by ground waters from the soil and rocks of the land, was brought in by streams, and deposited to form thin bands of ironstone. Further shoaling of the waters by sedimentation 
or uplift, occasioner the accumulation of sands (No. 5). A deepening of the water again caused the deposition of muds (Nos.6 and 7). The nccurrence of sandy layers within this shale formation points to occasional changes in the depth of the water or, more likely, in the strength of waves and currents. At length marsh conditions were restored (No. S) Is sedimentation building the bottom up to the water surface, or by an elevation of the bottom or a lowering of the surface of the water. This second swamp appears to have lasted about half as long as the first, judging by the relative thickness of the coal seams. Submergence led to the burial of its regetation under the muds represented by No."

The above section represents but a small portion of the Pesunsylvanian system. Deep borings show that the rocks of this period have a thickness of some 1,200 feet in certain places in central Illinois. A general section of the Pennstvanian rocks of the State prepared by Worthen represents the system as containing 95 distinct formations. Sixteen coal seams (not all workable) are indicated, separated by shale, sandstones, and limestomes. No other system of rocks within the State records so remarkable a series of geosraphic changes.

Older formations. As already indicated, no rocks older than the Pennsylyanian outcrop within the area covered by this report. Older beds have been penetrated by artesian wells, however. and locally they have importance as a source of public water supply. The porous, water-carrying formations in question rise slowly toward the north and come to the surface in south central Visconsin. A part of the rain which falls there sinks into the ground and follows these slanting (dipping) purous berls to the south. Since each of them is covered by relatively impervious beds, the water they contain below the middle Illinus Valley is under the immense pressure of a sloping column of water which fills the pores of the rocks, and extends northward to the area of nutcrop. Accordingly, when the impervious cap is penetrated by a loring, the water is forced toward, and in some cases above the surface. Not all the artesian wells of the area reach the older (prePennsylvanian) formations. The public wells at Putnam and Bureau, for example, obtain water from the T'ennsylyanian rocks.

The older formations outcrop mure or less extensively in neighboring areas, where they have leen studied in some detail. The general characteristics which they there possess are believed to hold in the area here described. Deep borings are so few, however, that it cannot be affirmed with certainty that all the formations mentioned below extend throughout the area, nor that others 10 not exist in parts of it. Figure 15 shows in the order of their occurrence, the formations encountered by the deepest wells of the region. The general succession of events recorded by these formations may be very briefly indicaterl, commencing with the oldest formation.

"Lower Maynesian" limestone.-This formation, which is reached by the artesian wells at Princeton, is the oldest formation exposed within the State. It may be seen a few miles beyond the area under consicieration, near Ltica. Here an up-warping of the beds has exposed formations, which a short distance to the west are deeply buried. 
The "Lower Magnesian" formation is in notth central fllinois a complex series of beds, containing many layers of limestume and sandstont.

The limestone beds are marie up

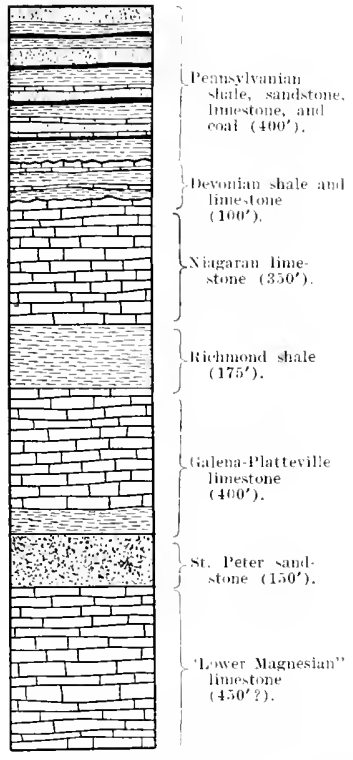

Fu. 1:. Section showing rock formations that ine penetraterl loy the leepent wells of the notliern part on the area. chichly of the remains of marine animals, which dwelt in clear and yuict, but only noderately deep vater. During the formation of hese bet!s the areas of accumulation ware therefore bevond the reach of alomdant sediment from the lanel. The associated sandstone layers show that now and again sands vere washed to the places uniler consideration. The alternation of limestone and sandstone layers may have been brought about by variation in (1) the lepth of the llater, (2) the strerigth of waves and currents, (3) the height of the adjacent land, or (4) the volume of the streams draining the land. An influx of sand would be invited ly shoal waters, strong waves amil currents, and high land liained ly large streams. The "lowel Itagnesian" limestome is widely dintributed outside the area considered in this report, registering conditions similar to thove described alwwe over a large arra in the northern Nississippi basin.

St. Pcter sundstone. - During the epoch following the deposition of the "Lower Magnesian" ins one. the region was covered with "Iater sufficiently shallow to insure the uninterrupted leposition of sand. These conditions are recorded by the St. Peter sandstone, which has a thickness of over 150 feet at Princeton.

Like the subjacent formation, the St. l'eter sandstone has a wirle distribution beyund the area here considered. It is commonly very porous, ani so an important reservoir for artesian waters.

Galcna-Plattcrill limestone.- This limestone implies another change in the conclitions of sedimentation, the probable nature of which will be readily inferred from preceding paragraphs. A sligh ć ceepening of the water or a lowering of the land appears to have excluded the waste from the land, and permitted the remains of lime-secreting organisms to gather upon the floor of the shallow sea until a leposit 
over 400 feet in thickness was formed. Fine sand and shales at the bottom of the formation suggest a gradual transition from the conditions of the precerling epoch.

Richmond (Hudson River) shales.-The next vounger formation is composed primarily of shale, and subordinately of limestone. During the greater part of the epoch the region would therefore appear to have leen in the outer part of the zone within which the waste of the land accumulates, and bevond the reach of coarse sediment. An occasional clarifying of the ocean water would have allowed the formation of the associated limestone. The formation has a thickness of 175 feet at Princeton.

Viauaron limestone. - The Richmond formation is overlain in this region wy some 325 to 350 feet of limestone comprising the Niagaran formation. This limestone points to conditions of sedimentation with which we have becone faniliar; a sea reep enough so that waves and currents were ineffective at the bottom, upon which the remains of thousands of generations of sea animals gathered.

Deronian shales and Iimostones.- Irtesian wells at Hennepin and Princeton show 100 feet of shales and limestones resting upon the Niagaran formation. The Devonian system of rocks, to which they are thought to belong, is separated in northern Illinois from lonth the underlying and overlying beds hy an erosion surface. Each of the erosion surfaces (unconformities) indicates (1) a period of submergence during which the beds lelow the unconformity were deposited, (2) emergence, due to elevation of the sea floor or lowering of the water surfact. (3) a period during which the exposed beds were eroded, (4) submergence, and (5) the deposition of the vounger beds upon the eroded surface of the older formation.

The beds which overlie the Devonian are the Pennsylvanian beds whose formation during a long period of oscillation when the region stood at and near sea level, has alrearly been descriloed.

Time inz'ol'te.-The remarkable series of events outlined above covered a period of vast length. While it witl never be possible to determine its length accurately, it doubtless comprised many millions of years.

Uplift and erosin.-Following the deposition of the Pennsylvanian beds, the region was exposed! as land and so far as known never again submerged beneath the sea. The new land surface probaly had some such topography as a plain formed by the withdrawal of the waters off the east coast of the [nited States would have. That is, it probahy possessed a moderate seaward slope, with inconspicuous minor unevennesses. Since cementation is usually a very slow process, the material of the new land may well have been feebly and imperfectly bound together.

The new land surface became at once the scene of activities which are now in progress in the region, and are therefore a matter of common observation. Then as now the rain penetrated the pores of the rocks and often removed their soluble materials. Surface rocks were split and broken through alternate expansion and contraction under the influence of heat and cold. Fragments of rock were pried off by the 
freezing of water in the cracks and interstices. By these and other processes of weathering, constant ardditions were marle to the initiall. loose surface material.

Furthermore, then as now, the finer surface material was frequently shifted from place to place. Winds probably blew dust and sand in quantity from bare surfaces and cieposited them elsewhere. The effeci was to roughen the surface, lowering it in some places, and building it up in others. Such rain as did not immediately sink into the ground, or evaporate, ran off the surface. If, as suggested. the generat seaward slope of the land was modified by minor slopes. the rum-off woulfl be uneven, concentrating along the lowest lines of descent. Clay, sand, and at times perhaps coarser materials were dragged and pushed downslope, in largest quantity along those lines where the volume of the run-off was greatest. The greater removal of material along such lines created depressions, which were steadlily enlarged by the waters which subsequently flowed through them. These depressions were valleys. When their bottoms were worn below the level at which the rocks were full of water, water from either side flowed into and along the vallers, forming permanent streams. Much of the rock waste washed by the streams along their channel floors was carried heyond the area under discussion to the sea.

The effect of cutting many valleys was to make the originally flattish surface rough. But streams cannot erode their channels much below the surface of the lake, sea, or river into which they flow, and can reduce them to that level only at and near their mouths. As they cut their valleys toward this final level their grarlients become less and less steep and their currents therefore more and more gentle. When they become sluggish, the streams may be readily turned aside by obstacles, and directed against the valler sides. Side cutting develops a valley flit at the expense of the inter-valley uplanils. The latter are also rerluced by other agents which aid the streams, and the entire surface may finally be worn down to a flat plain, as near sea level as running water can bring it. Such a plain is a base-lcvel plain. A plain in the stage of development precerling this final condition, is a peneplain. Its surface is usually characterized by isolated hills formed of resistant nuterial or so situated as to have escaped erosion, which rise abtuptly above their nearly level suroundings. The time necessary for the production of a base-level plain is a cycle of crosion.

If a base-level plain be elevated and the slope of its streams thereby increased, they begin at once to lower their channels, and unless prevented by other geological agents, will in time again reduce the area to base-level. The region considered in the report may have been baseleveled more than once before the advent of the ice sheet that deposited the clay, sand, and gravel which commonly covered the bed rock deeply. Such a possibility is especially likely since extensive base-leveling is known to have occurred in a large unglaciated area in northwestern Illinois and adjacent states. 
If a sufficient number of wells reached the bed rock and their records were available. it would be possible to describe in detail the relief of the underlying rock, but unfortunately for this purpose, the great majority of the wells terminate in the glacial material, and only a general notion of the topography lefore the deposition of the glacial mantle may be obtained. The principal feature of the pre-glacial topography was the Rock-Illinois Valley (fig. 16), whose tloor is shown by well borings at several places to be about 100 feet below the level of the present river.

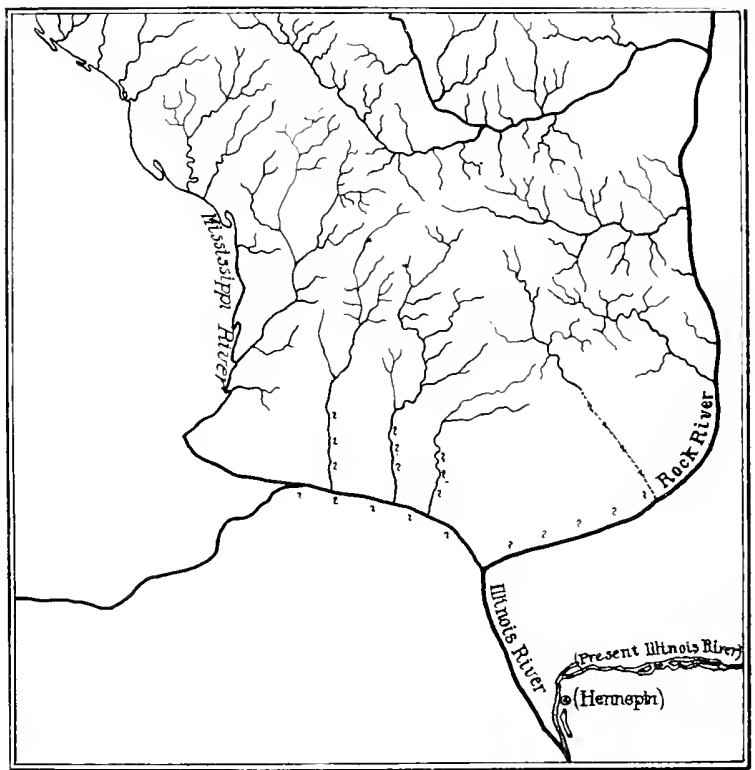

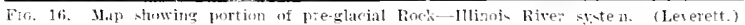

It has been conjectured that the pre-glacial Rock-Illinois River was joined by the upper Mississippi at a point to the north of Hen:epin (fig. 16), though this is by no means proved. The pre-glacial uplands were apparently much dissected by tributary valleys, and rose in places nearly 450 feet above the Rock-Illinois Channel. The region appears to have been a rugged hill and valley country, possibly closelv resembling the unglaciated area of the northwestern comer of the State. 


\section{CHAPTER III.}

\section{THE GLACIAL PERIOD.}

The mantle rock of the area is of forciun derization. - As indicated on preceding pages, the Tennsylvanian rocks of the region of the middle Illinois are generally covered with clay, sand, and gravel to an average thickness of probably wer 200 feet. These materials occur separately in many places, and are elsewhere confusedly mixed in all possible proportions. It has long been known that this mantle rock was not produced by the weathering of the underlying rocks, for it contains much material. for example bowlders of igneous rocks, to which the decay of the bed rocks could not give rise. ${ }^{1}$ This fact is also shown by occasional exposures of the contact between the mantle and the unterlying rock. Mantle rock formed in place normally grades more or less insensibly into the firm rock beneath (fig. 17). This is a consequence of the gradual downward diminution of the work of the atmosphere, ground waters, plants, animals, and other agents of weathering. Ai the exposures in question, however, the surface material gives place

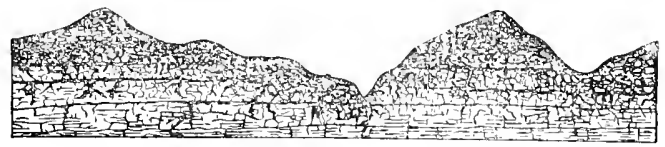

Fit, 17. Diaglam showiug the relation of mantle rock to the umlerlying rock from which it was deriverl. (Courtery of $\mathbf{U}$. $\mathbf{S}$. (Geol. Surv.)

abruptly to the unaltered rock below as suggested in figure 18. The mantle rock of this region, therefore, was brought to its present position by one or more of the agents which transport materials upon the land. Together with similarly importerl materials which have wide distribu-

${ }^{1}$ The foreign derivatinn of the granit. Mowlders was discused as follows in 1836: "Bowlders, or detactid massen of stone, are occasionally spen on the prairies, lying loosely on the ground, not only entirely keparate from the limestone pan beneath, but differing from it in kind. They are obviously not meteorin: ; and it seems that they have been wrenched from their native beds, and brought to the places whese they are now seen, ly some great onrtalsion of nature. They are gramite, and there is no spot at which the deseription of rock exists, and from which they could have been brought, nearer than the Allegheny, or the Rocky mountains, or the northern shores of the lakes. Yet they are numerously scattered throughout lllinois and Missouri." (Hall, Statistics of the West, p. $9 \overline{5}, 1836$. 
tion oser the nuthern part of the l niter States, it is known as drift. This term was applied under the impressiom that it had been drifted by waters to its present situation from outside sources.

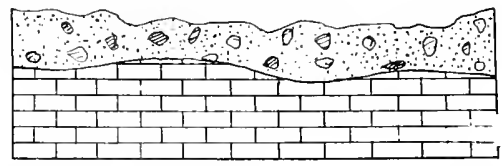

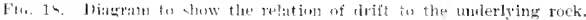

The transportimy agent.-Plate I'I, Ii shows a typical exposure of unstratified drift (till) near Hens. Similar exposures may be seen throughout the region. As in the illustration, the till usually consists of material of many kinds and sizes, and is not in layers. Some of the angular stones and boulclers have flat faces, often highly polished, and covered with minute scratclues ( 11 . VII). The drift is sometimes (often in other areas) quite irregularly dispused, sn as to occasion hilly betts and unclrained depressions. The stones and bowlders are frequently of kinds which lo nen occur as bed rock nearer than Canada. The transporting agent, therefore, gathered its load from an area sufficiently large to yield many different kinds of rock, and was capable of carrying large boulders as well as fine clay, sometimes for great distances. It wa capable, furthermore, of giving a part of the stones it carried the characteristics noted above. but was incapable of arranging its irregular leposits in layers.

It is evident that the transurting agent in question was neither the wind nor ruming water. The size of the material would, among other things. at once exclude the former, while varions considerations as effectually dispose of the latter. The largest bowliters of the till, weighing tons, are far beyond the transporting power of ordinary streams. Streams tend to round the stomes rolled along their chamels, and are unalele to develop flat faces. Stream-laid beds are in lavers. The surfaces of water-ileposited beds are without notable irregularities. such as occasionally characterize the till.

Plate Ti. A shows irregular deposits recently made by the Alaskan glacies in the backeroumd. that possess all the characteristics of those shown in Plate YI, B. So far as observed all the deposits being made by existing glaciers, show these same characteristics. Since existing giaciers are developing exactly the features belonging to the drift of the area under discussim, and since no other agent is known, capable of so doing, we may confidently conclurle that the region of the middle Illinois was formerly covered by glacier ice. This glacier was as extensive as the till is widespread, and is therefore known to have covered at its naximum development, the area shown in figure 19.

The ylaciation of the roqun complex- - Further considerations make it apparent that this area was invaded by glaciers more than once, and 


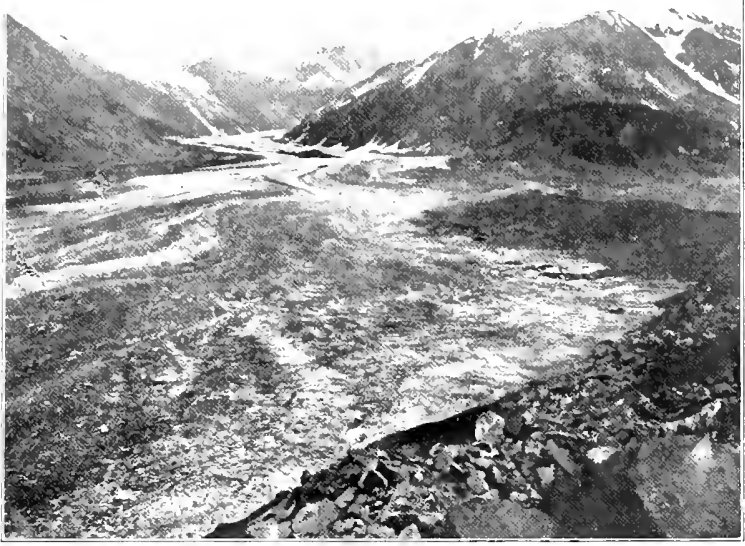

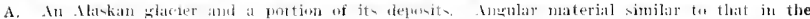

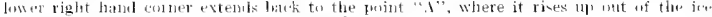
(l'huto by Martiu.)

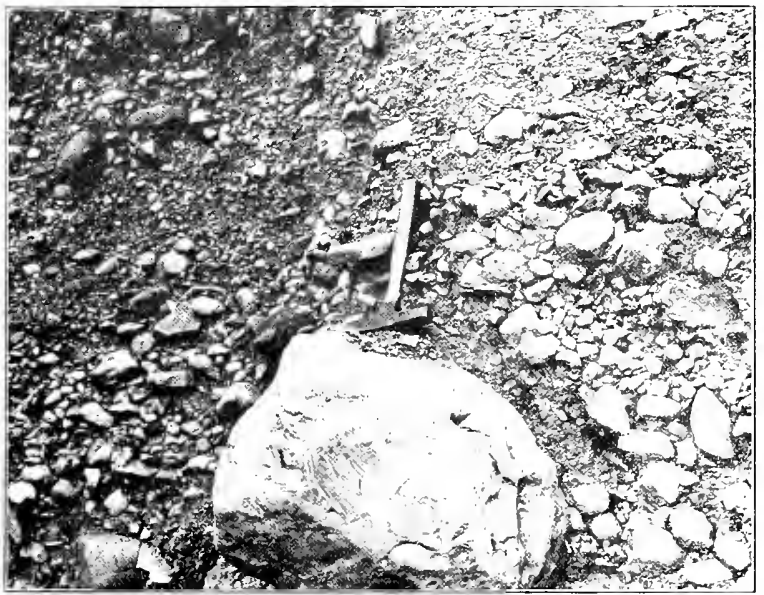

B. Typical exposure of till near Benry. (Photo by Crane.) 

at widely separated intervals. A recent cut of the Peoria and Bloomington Electric Railroad, near the former city, shows the following beds, number 1 being the lowermost and therefore the oldest:

Thiofitexs.

4. Atony till-Buttom $14 \mathrm{ft}$. blue and highly malcarems; upper 2.i-3a ft.

b. Bwn; upper 4-5 ft. mu-cilcareous, and reldi-h-yellow in color........

small snal thells; bottom $f$ iaches drab-gray color. . . . . . . . . . . .

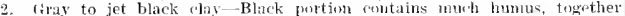

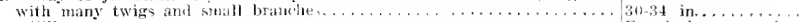

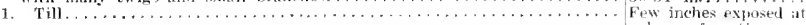

This section records the following sequence of events. (1) The presence of the ice sheet by which the till (No. 1) was deposited. (2) An amelioration of climate which callsed the ice to melt back so far and

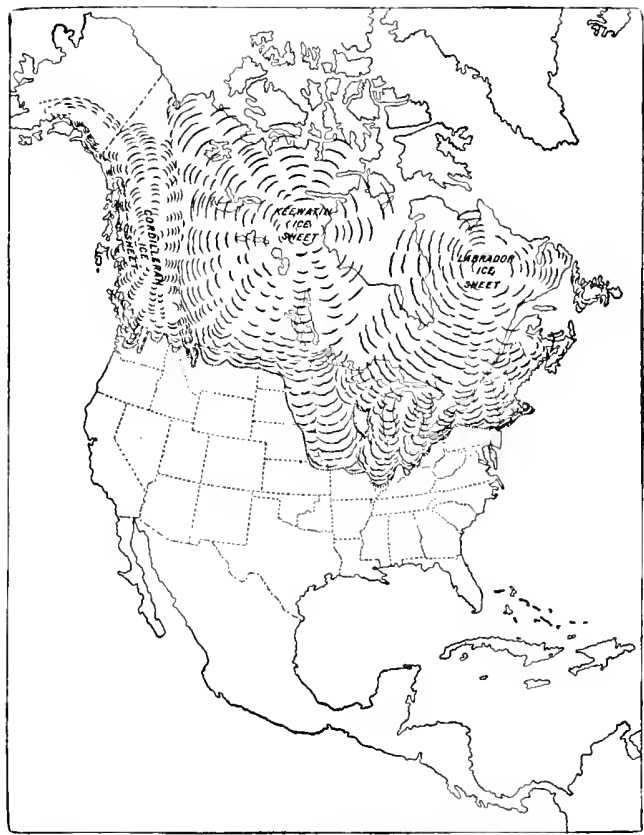

F16. 19. Map showing maximm extent of ice sleet, of frlacial period in North America. (IT. S. (iend. Sint.) 
remain away so long that plant life. fowly invading the abandoned area, grew ipon the lejurts left by the ice. Decaving roots, leaves, and twigs mingled with the clas to form a layer of soil (No.2). (3) The leposition therem of fine silt $1, x$ wind or water (No. 3). (4) since the silt (loess) of this huri\%m is el-ewhere calcareous, save in its uppermost portion, it seems reasmable to suppose that the silt of this section was also originally calcareous. If so, its deposition was followed by a periol of weathering, during which the loess was leached of its calcareous comstituents. That such leaching occurred before the leposition of the overlying material is evident from the fact that the bottom of the till which rests upon the loess is highly calcareous. (5) A rearlvance of the ice, which overrode the earlier lieds and deposited the till indicated by No. 4.

South of Peoria, the valleys tributary to the Illinois are, on the average, larger and more numerous than those north of the city, and the upland is, in consequence, more dissecterl. Since these valleys are developed in material of essentially the same resistance, this indicates that the drift area to the south has been longer exposed to the work of the agents by which valleys are developed, than has that to the north, or in other words, that the drift sheets in which these different sets of valleys have formed, are of unequal age. Figure 2 shows the difference between the Spoon River and the lower Sangamon River systems, developed in the area of the older drift, and the drainage srstems of the younger drift. The former have numerous tributaries which branch widely; the latter displas little branching. The greater age of the southern drift sheet is also indicated by the fact that gromel waters have removed its soluble constituents and oxidation has given it a brownishyellow color to a greater depth than in the case of the northern sheet. From such considerations as the foregoing, it has been determined that there were five distinct invasions of the Lnited States by glaciers during the Glacial period. These epochs of ice invasion were separated by periods when the ice retreated an unknown distance to the northward, and the abandoned areas experiencerl the more familar geological work of the atmosphere and of ruming vater. Theie were also minor advances and retreats, evidence of which in the area under discussion. appeats helow. The general sequence of events during the Glacial period is traced in the following pages in so far as it affected the region of the middle Illinots River.

The formation of the ylaciers. At the beginning of the Glacial period the climate of northeastern Canada became such that in certain areas more snow fell each winter than melted and evaporated during the ensuing summer. The resulting accumulation of snow constituted a snow ficld. It increased in thickness with the contributions of successive winters. It became larger as the conditions of excess of snowfall over snow waste were extented. This extension the snowfield itself promoted by lowering the temperature of the surrounding atmosphere, thus inviting an increasing proportion of the precipitation in the form of snow, and at the same time retarding melting and evaporation. 

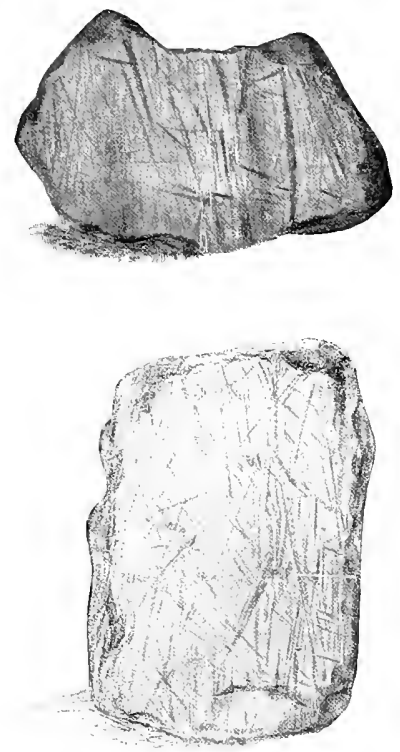

Glaciated stone- howing form and strite. 

Heanwhile the snow field hecame an ice ficld by the same proctsses which each winter transform many snow banks into ice banks. (1) The botton snow was compresed by the weight of that above, the result lreing something like that when loose snow is packed into an ice-like ball in the lands. (2) Water from rains and from surface melting during the wanner periods sank into the snow beneath and freezing, formed ice which helped to cemcut the mass together. (3) The snow crystals underwent changes in form which aided in the development of compactness.

From the circumstances of its develonment, the growing ice-field, with its cover of lately fallen snow, had greatest thickness in the center, diminishing more or less regularly to the margins, where wastage halanced snowfall. The pressure upon the bottom ice was accordingly greatest near the center, lecreasing to zero at the edges. In consequence the ice slowly spread in all directions under its own weight and then it had become a glacier.

In the general way indicated, one glacier or ice sheet developed east of Hudson Bay, while a second formed to the west (fig. 19). Slowly spreatling loy marginal adilition of snow as well as by novenent. these glaciers irined south of Hudson Bay, and in the course of the Glacial period covered the area already referred to in figure 19.

The Illinoian stafe of glaciation.-So far as known, the area lescribed in the report was invaded only by ice from the Labrador region, moving in a general south-southwesterly direction. The direction in which the ice noved is shown w the direction in which the material of the drift was transported, and by the trend of the margins of the till sheets which occur within the region. The first invasion of this region that has been recognized was the thirol invasion of the United States. It is linown as the Illinoian stage of glaciation and its deposits as the Illinoian drift.

As suggested on page 24, a general notion of the character of the topography at the coming of the ice may be had from the recorts of wells scattered throughout the area. They show that the present Illinois River below Hennepin follows the course of a great pre-glacial valley (fig. 16), whose floor was some 100 feet below the present stream bed. This valley was bordered by uplands that appear to have been well dissected by small valleys, and that in places were nearly 450 feet above Ruck-Illinois River. The surface of the ground was presumals? mantled by loose material derived from the underlying rocks.

Nany erosion slopes faced the invading ice and acted as obstacles to its advance. The relatively thin edge of the ice sheet, thus opposed. probably crept very slowly over the meven ground. Its first effect was doubtless to remove the joose surface material. Wherever the water in the soil upon which the ice encroached was frozen, it cemented the soil particles into a firm mass. Wherever this ice-cemented soil became frozen to the glacial ice above, it became, in effect, a part of of the ice sheet, and was likely to be carried on by its further moventent. Some loose material may at times have been pushed forward by the advancing ice edge, though the great mass of it was probably gathered by the 
under surface of the ice. Such material may have heen dropped and picked up again many times before reaching a final resting place. Elevations in the path of the ice might occasion lodgment. Noving vigorously over a surface vielding abundant material, the ice might gather a load which it was presently, under changed conditions, unable to move. It its edge the moving ice was continually melting, the excess of moventent over melting being the measure of its adrance. In consequence of this marginal wastage, rock material picked up by the ice at some distance back from its edge would, if not dropperl, find itself in time at the margin. whose melting would occasion its deposition. Overrituten by the alvancing ice, it might once more be taken up. to be again dropped after a longer or shorter journey. The removal of the lowe surface material was unduulutedly followed by more or less erosion of the bed rock. This is largely a matter of inference, as the bed rock is for the most part buried leeply by drift. Since it is much softer than rock. pure ice accomplishes little or no wear upon its bed, rather is it wom by the harder rock. As indicated above, however, the bottom ice was charged with rock fragments and thus armed, glaciers, become efficient agents of erosion. Their rock tools are pressed with great force upon the surfaces over and against which they move, and each kind accomplishes its appropriate work. Clay particles tend to smoth and polish. sand grains and hard pebbles to scratch (striate) and bowlders to groove an! gouge the bed rock. Meanwhile, the toots are themselves worn. The weaker ones are presently ground into fin bits. The stronger are lypically marked, their sides being worn flat and like the bed rock, often polished by clay and striated by sand (PI. VII). Such glaciated stones may le seen in almost every exposure of till throughout the region.

The effect of glacial erosion was probably to plane away minor irregularities of the surface, reducing and smoothing the slopes. Where hillops were worn, the tenflency was to reduce the pre-rlacial refief. Where the ice moved along the axcs of valleys it tended to widen and deepen them, and so to increase the relief. Where it crossed valleys. the ice was likely to erode chiely the sides out over which it moved.

The Illinoian ice sheet covered the entire area under description and pushed well beyond it. On the west it crossed Mississippi River and advanced some distance into Iowa, while it fell short of Ohio River at the south by only a few miles (fig. 20). This was the limit of its advance, because here wastage balanced movement. It is evident tha: alf material moved by the ice to the limit of its advance would be leposited, and that the longer the ice edge remained stationary the more considerable the deposit would be. The resulting thickened edge of a drift sheet is called a terminal morainc.

After a time, wastage excceded forward movement and the edge of the Illinoian ice accordingly withdrew from the area covered by this report, and from much or all of the territory it had covered within the limits of the Lnited States. As it melted hack, all the material that had been on top of the ice, in the ice, and beneath the ice was left on the deserted surface, together with the material that had been deposited 


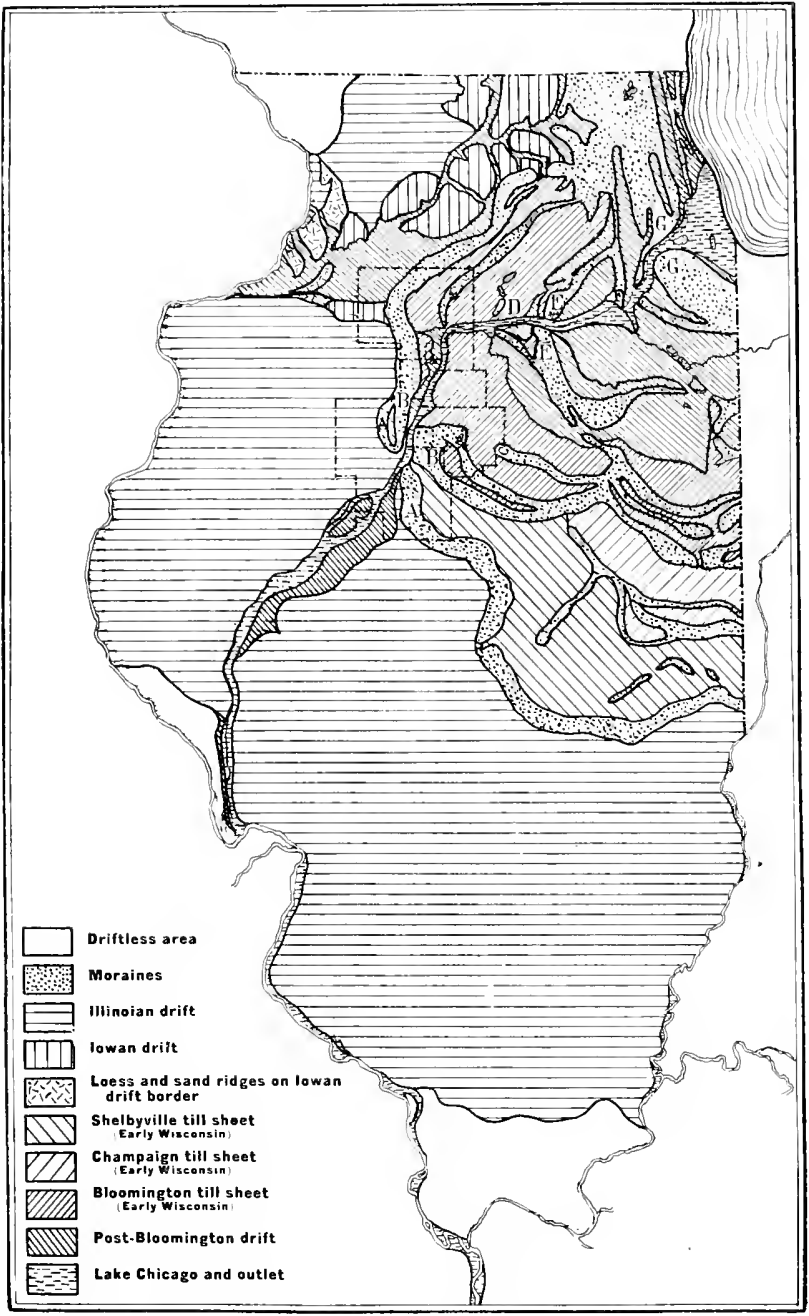

Fig. 20. Generalized glacial map of llinois. (Ilata from Leterett - map. Munguaph s-. U. S. Geol. Surv.) 
while the edge of the ice was alvancing and while it renained stationary. The material cenositel beneath a glacier back from the terminal moraine, comstitutes the yround moraine.

Stratifod drift.-While leposits that were made directly by the ice are without stratification, a consikerable proportion of the drift was deposited hy waters associated with glaciess, and is therefore stratified.

Dejosits of this class were mobaly male lefore the advent of the ice. Naters forme:l by melting ice in some cases found valleys learling away from the ice fromi. Loaded with debris from the ice, such streams probably aggraded the valleys they followed, the deposits assuming the structure common to siream-laid beds (p. S). Such valler fillings, built by streams bevond the ice elge, are known as ralley trains and will receive nore detailed consideration later. When the advancing ice occupied the lower courses of valleys. but not the upper, it acted as a temporary dam and formed a pund or lake, on whose floor stratified deposits were made. The stratified drift deposited beyond the arvancing ice front was later overricklen by the ice sheet, and wholly or in part molified, remover, or buried by till.

During the time that the Illinoian ice sheet covered the area under discussion. stratified leposits were robably being made in places beneath the ice. Water from the surface melting of smmer doubtless found its way in part inrough cracks and crevasses to the bottom. Some melting, furthermore, occurrel at the bottom because of friction with the rock leneath. In these and other ways very considerable quantities of water accumulated moler the ice, and were at certain times and places concentrated into definite sub-glacial streams which deposited sand and gravel along their channels. These deposits may have been laid down upon bed rick, upon earlier stratified drift, or upon till, and mas have heen subsequently crvered by later deposits, either stratified or unstratified.

During the withdrawal of the ice from the region, glacial waters tended to make deposits similar to those formed during its advance. These deposits, in so far as they were male by waters flowing outward from the ice edge, were not subject to modification or burial br the Illinoian ice.

From the foregoing it will be seen (1) that glacial waters tended to form stratified drift in certain places under the ice and at and beyond its edges, during its advance orer the area, while it covered the region, and ciuring its retreat from it: and (2) that such stratified drift may be mnder, within, or on top of mstratified drift deposited directly by the ice. Further complexity in the leposits of an ice sheet is brought about by the fact that the advance and retreat of its edge are commonly interrupted hy temporary halts and minor movements in the opposite direction. it is therefore not suprising that locally, as along the valley of Kickapon Creek and Illinois River near Peoria, much stratified sand and gravel occurs in the 1llinoian (lrift. In keeping with the above principles, atso, limited exposures of stratified gravel appear in the 
midst of the till at numerous points, apparently marking the sites of glacial streams. This gravel has been freutuenty cemented by deposition of material from solution in ground water, so that it forms a rock sufficiently strong to have heen used for the foundations of buildings.

The Illinoian till is comnunly yellow or yellow-brown in the upper 10-15 feet, because of the oxidation of its iron; it grades downward into unweathered gray till.

Effect of the Illinoun glaciution upon lopouraphy-The general effect of the Illinoian glaciation of the region was to reduce its relief. With the exception of Illinois Valley, the pre-glacial erosion channels seem to have been largely or wholly fillerl with drift and to have practically ceased to exist as surface features. An essentially plane surface replaced the rugged pre-glacial topography. This change is illustrated in figure 21 .

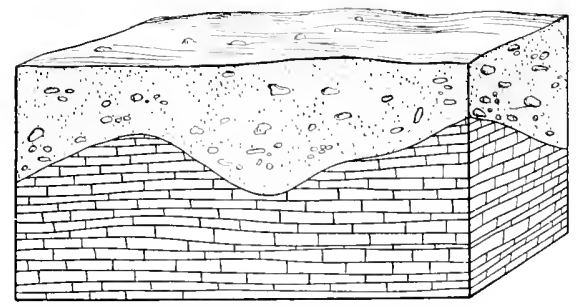

F19. 21. Diagram to illustrate how romgl pre-glacial topugraphy nay be replaced by a smouth surface through the depositim of drift

Another important consequence of the glaciation of the region, which has been referred to the Illinoian stage, was the diversion of the upper portion of Rock-Illinois River. The bluffs of the pre-glacial valley have heen traced by Leverett from the point where the present Rock River turns sharply to the southwest in southern Winnebago County, nearly to the southern boundary of Ogle County, where they disappear beneath a heavy deposit of drift. Well recorls seems to show that the old valley continues past Princeton to the lend of the Illinois at Hennepin. The displacement of the river is referred to this, rather than to a later stage of glaciation because the work the stream has accomplished in its new course seems out of proportion to that known to have been done by other streams since later stages. The ice appears to have filled the valley, displacing the stream to the westward. When the ice withdrew, the valley was choked with drift and the river had found a lower line of discharge to the southwest, in part along the line of preglacial tributary valleys. The abandoned valley was further buried by later drift sheets. 
The Sungamon intertlacial epoch.-At the withdrawal of the Illinoian ice sheet the area with which the report is concerned becane at once the scene of new activities. Fine material blown about by the winds found lolgment in new situations or was carried outside the area. The chemically active oxygen of the atmosphere entered into combination with certain constituents of the drift, giving its surface a color resenlling that of ruster iron. The rain-water that sank into the grount dissolverl the soluble material near the surface. The streams tonk up the task of reducing the surface which the ice had built up. The conditions of their work ware unlike those which affected the preglacial treams. In general, the shope were less steep and the streams. therefore, more luggish. This disarlvantage was in some measure comnteracted by the les resistant material upon which they worked The Illinois was probably seriously retarded in the work of clearme out it suever valley by the loss of the waters fomerly contributer br kock River. Plants and animals presently re-established themselves in the area, and influenced the operation of other agents. The remains of plant life mingled with the surface material to form soil.

The record of these interglacial activities is preserved in the leached and reddened upper surface of the Illinoian till, in shallow valleys, and in oll soil layers. These features were clearly developed hefore the deposition of the overlving beds, and may be seen in certain places where the latter have been removed by erosion. The soil of this time is exporsed at the point on the Peoria and Ploomington Electric Railway referred to on page 27 , and the weathered surface of the till is shown at many points sruth of Peoria below a capping of younger silt.

Judging from the coniferous trees represented by hits of word preserver in the Sangamon soil, it has been thought that the climate of the region during at least that part of the interglacial epoch when these trees grew, was much colder than at presont. The duration of the interglacial epoch is not definitely known, but the weathering acromplished seems to indicate thousands of years. The Sangamon interval was lrought to a close by another epoch of glaciation, known as the Iowan.

The Iowan loess. - The extent of the ice sheet at the Iowan stage of glaciation is indicated by the extent of the Iowan till, ${ }^{1}$ The ice is accordingly known to have fallen short of reaching the southern line of western Pureau County, as indicater in figure 20. Some distance west of Princeton the southern edge of the Iowan till passes beneath a heary deposit of rounger drift, so that its southern limit within the area of the report is mknown. Quite possibly it did not extend sruth of Bureaut County. The near approach of the ice was of :noment to the entire area with which the bulletin is concerned, however, hecause of an important deposit of loess to which it gave rise. The loess in question

1 Question has recently been rabel concerning the correctness of the current intreyretation of the Jowan drift. 
is widely distributed beyond the area. It is believed to be genetically related to the Inwan ice because it thickens toward the edge of the Iowan drift sheet, upon which it extends but a short distance.

Loess is silt intermediate in coarseness between fine sand and ciar, into both of which it grades. Predominantly buff yellow in color, it is in some cases dark brown and in others blue gray. Its mineral composition is essentially that of the drift from which it appears to liave been derived. Typical loess is pebbleless, without distinct stratification. and frequently contains concretions and large numbers of fossils. The concretions are aguregations of lime carbonate of irregular shape ( Pl. V1I1, B). formed ly deposition from solution in ground water of material leached from the surrounding loess. The fossils are the shells of minute mollusks (gastropods) which were buried in the gathering losss.

The loess appears to have covered originally the entire surface of the Illinoian drift in this region. It has been extensively removed by erosion in the vicinity of Illinois River, but often remains intact upon the uplands, where it has an average thichess of 12 to 15 feet. The loess is composed of somewhat larger particles and is more porous near Illinois Valley, and grades inland into a clayey earth. Numerous exposures show a vertical variation in the chracter of the lness. At the top there are 3 to 5 feet of weathered brown clayty loess, mixed with more or less humus. When dry, this top loess breaks readily into minute angular blocks. It grades downward into the typical buff loess, which is occasionally replaced near the bottom in the reeper cuts by a blue-gray silt.

The origin of the loess is a mooted question. It has been held to be (1) a wind deposit, (2) a water deposit, and (3) in part eolian and in part aqueous. The theory that it is exclusively a wind deposit has met difficulty in the fact that it sometimes contains material apparently too coarse to be handled by the wind and possesses lines of water sorting. The theory that it is entirely water-laid is opposed by its presence on divides far aloove the reach of depository waters, together with its absence from lower tracts which should have been flooded before the higher ones. There has accordingly come to be rather general agreement that both wind and water were concerned in its deposition, but there remains wide disagreement as to the relative importance of the two agents. It has been suggested that silt resulting from glacial grinding may have been carried out from the Iowan ice by sluggish aggrading streams that spread it broadly over wide flats at flood times, from which it was in part removed by the wind and redeposited upon the neighboring uplands. The present tendency is to assign an eolian origin to the larger part of the loess.

The Pcorian interylacial cpoch.-The loess which caps the Illinoian drift extends beneath the Wisconsin drift (footnote, p. 36), described below, where the loess outcrops in certain valley slopes. At the Peoria and Bloomington Railroad section noted above, the loess has a thickness of 6 feet and is non-calcareous. The blue till which overlies it is highly calcareons. It is therefore evident as alrearly noted, that the loess, un- 
dothtedly originally calcareous in common with the Iowan loess generally, was leacher of its limy contituents prior to the deposition of the overlying till. The period of weathering recorded by this and similar sections, which followed the deposition of the Iowan loess and preceded the advent of the IIisconsin ice has been called the Peorian interglacial epoch.

Weathering and erosion are much less pronounced than at the Sangamon stage and on obviously recorrl a shorter interval.

Farly If isconsin-The Shelhyille ice shcet ${ }^{1}$-The erosion and weathering just noted were brought to a close by another incursion of the ice. The drift sheet which reonrls this advance is named from the city of Shelbrville, situater at the southwestern extremity.

Tot all the area described in this report was covered by this ice sheet, the limit of its advance heing narked by the Shelbyville terminal moraine, figure 20, at " $A$." Since the ice continually moved material forward to its thinned margin, ant there deposited it, the submarginal drift accumulated faster than that farther back beneath the ice; and because the position of the ice edge remained essentially constant for a long period, the marginal thickening of the drift became considerable. This thickened belt of drift is the terminal moraine. It is most conspicuous when riewed from the Illinoian drift plain besond, alove which it rises rather abruptly, sometimes as much as 150 feet. The descent from it to the inner (eastern and northern) plain is much less. and is accomplished more grarlualiy.

The topography of the moraine within the area described in the report is hardly typical of terminal moraines in general. Its surface is rather smooth and rexular, whereas terminal moraines are more often characterized by irregular, hummocky topography. Not infrequently they contain numerous momols, hillocks, and short ridges, associated with depressions without outlet, which often contain ponds or lakes the whole huddlerl together in confusion. The elevations of such moraines range in diameter from a few feet to half a mile and more, and occasionally resch a height of 100 to 200 feet. while the depressions vary in depth from inches to scores of feet, and in area may cover many acres. Ferhaps the nearest approach to this trpe of topography within the area here considered is in the vicinity of Groveland, where shallow basins 2 to 6 feet in deptlo may be seen in connection with low mounds. Plate VIII, A shows morainic topography a few miles from ?urcati. while figure 22 illustrates the stmonger trpe which characterizes rertain other moraines of northeastem Illinois and Wisconsin. It has been sugsested that the usual irregular topography of a terminal moraine may have developed in the following manner: (1) More material was likely to be moverl to the vicinity of the edge of the ice in some places than in others. In such situations the moraine tended to becone higher and wider than elsewhere. (2) As in the case of present glaciers, the etge of the ice was doubtless subject to minor oscillations; melting back by summer and alvancing in winter; withdrawing during

The drift heets that are vounger than the liswan are commonly grouped as the early and late Wisconsin drift sheets. The shelbrville drift and the Bloomington drift (p. 38 ) are of early Wisconsin age. 


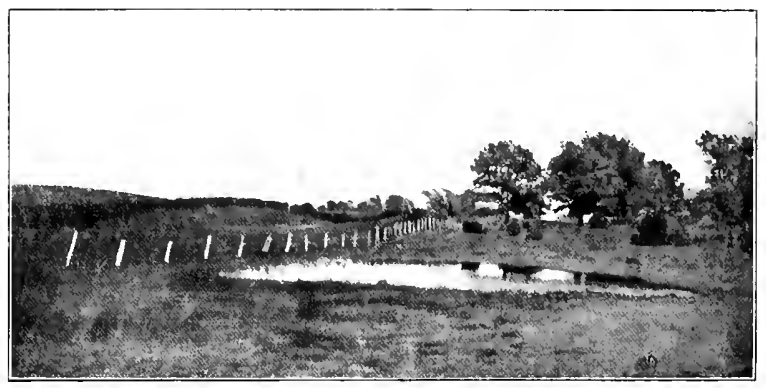

A. Morainic ropograply in not thern part of area, with gentle swells and shallow basins.

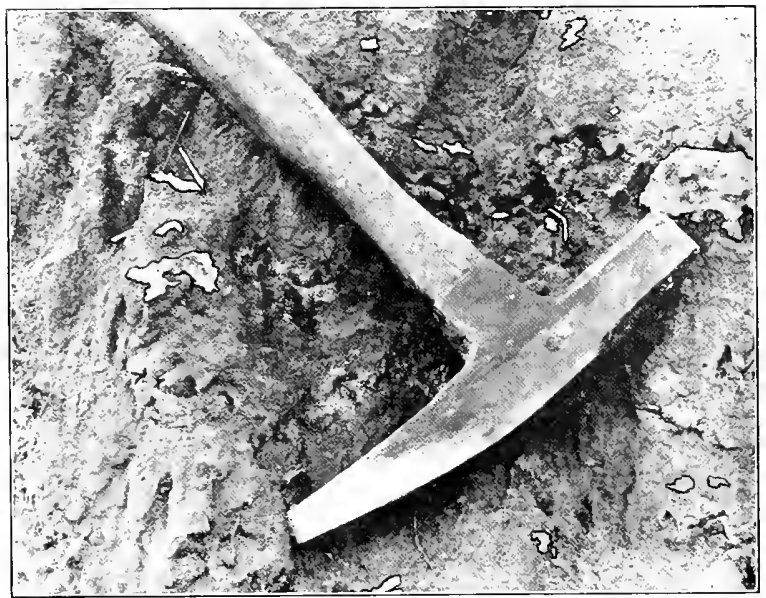

1) Exposure of luess containing concretins. The runcretions are outlined by black lines. (Photo by Crine.) 

a period of warmer years, with winter halts or short advances, to recover part or all of the lost ground during a period of cooler years. At each stage of such oscillations the irregular edge of the ice mav well have failed to be parallel to many or all of its earlier positions in much or all of its course, in which case the submarginal accumulation of drift then made was not parallel with earlier deposits of similar origin. Rather, the lines of debris marking the various positions of the edge of the ice crossed or met and receded from one another many times, enclosing depressions of diverse shapes and sizes. (3) The drift may have buried great detached blocks of ice, which, on melting, permitted it to settle unequally, forming depressions.

The faibure of the Shelbyville moraine and of the bloomington moraine (discussed below) to display pronounced irregularities of surface within the area, may be due to the edge of the ice having been unusually constant in position at those stages and more or less uniformly charged with debris.

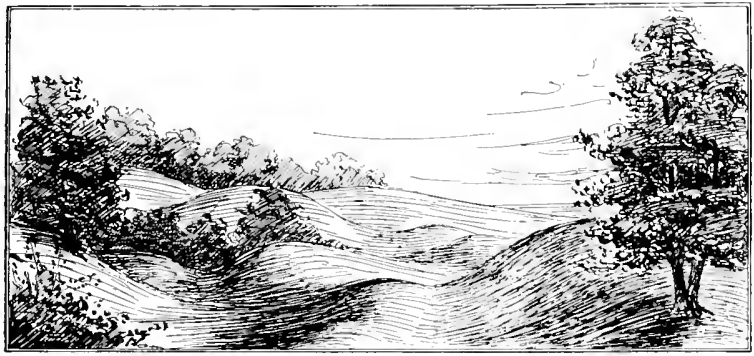

Fic. 22. Sketch of strongly developed terminal moraine topography.

The Shelbyville ice appears to have accomplished little erosion in this region in numerous places scarcely disturbing the surface material over which it pushed. This was probably due to the fact that the flattish surface developed by the earlier glaciation offered little opposition to its advance, and to the fact also that the heavily loaded border of the ice sheet which covered the area was in a depositing, rather than an eroding condition.

The Shelbyville drift probably does not contain as much sand and gravel as the Illinoian. The great mass of the material is a moderately stony blue clay. This grades into a yellow till in the weathered zone.

The silty loam which covers the outer slope of the moraine points to sluggish drainage from the ice front, strikingly in contrast with that at the next stage (p. 39 et seq). The absence of vigorous outwash from the Shelbyville ice edge, even along such favorable lines as those af- 
forled by Illinois and Kickapoo valleys, is singular. Since there was obriously abundant material to be washed forward from the ice, the apparent absence of outwash in such valleys can be explained only by assuming that the issuing streams were of little volume, and that their channels were of low slope. It is difficult to see how these streams could contain little water, unless fed by a small amount of melting ice. If this view be entertained, it must also be assumed that the marginal ice, whose wastage balanced ice advance, was in the main disposed of in some other way than by melting; in other words, by evaporation. This would in turn seem to demanit an arid or semi-arid climate in central Illinois at the tine.

The Bloomington ice sheet.-The Bloomington moraine (fig. 20, at " $\mathrm{B} "$ ) is named from the city of that name, centrally located upon it. The etge of the ice remained stationary along this line for a period sufficiently long to permit the submarginal accumulation of drift to becone notalily thicker than that farther back. The ice edge did not merely halt in this position in its retreat from the Sluelloyille moraine. Having withlrawn an monown distance, it again advanced to this line. This is indicated by the fact that shallow valleys, cut in the Shellyyville drift, received the outwash from the Bloomington ice front. Furthernore, the older moraine disappears beneath the Ploomington moraine in the northeastern part of Peoria Comnty near Lawn Kidge. North of this point, and west of our area, the younger moraine has been found to be in contact with pre-IVisconsin drift (footnote, p. 36). For the interval between the Slielbyville retreat and the Bloomington advance no name has been given. The inner Blonmington moraine, which extends northward from the vicinity of the great bend of the Illinois (fig. 20, at "C") may be a recessional moraine, merely registering a stand of the retreating ice.

The description of the Shetbrville noraine and drift is in the main applicable, within the area here considered, to the Bloomington moraine. Hetween I'enria and Lawn Kilge (Peoria and Dunlap topographic sheets) the moraine is prominent, reaching in places an elevation of 820 to 830 feet above sea level, nearly 100 feet above the narrow Sthelbyvile drift plain to the west. The crest of the Bloomington moraine here acts as the divicle between the upper waters of Kickapoo Creek and the small valleys leading eastward to the Illinois. The proximity of the moraine to Illinois Valley determined the shortness of the vallers hearling on its eastern slope. These valleys gradually lengthen northward as the distance increases between the moraine and the main valle!. In the vicinity of the eastern bluff of the Illinois Valley the moraine is weakly developed, merging stadually into the inner" plain.

The surface of this moraine nowhere displays pronounced irregularities, apart from those leveloped on its slopes by stream erosion. North of Peoria only occasional depressions 2 to 5 feet in depth were noted associated with inconspicuous swells. East of the river there is even less leparture from planeness. The hummocky topography reported to 
characterize the inner Bloomington moraine to the north of the area, becomes subdued as the Illinois is approached, in the vicinity of which the moraine appears to fade out entirely. Low mounds and shallow basins on the uplands east of Hemnepin are in line with this moraine, which reappears on Leverett's map (fig. 20) in eastern Woodford County.

The surface of the till, where exposed, is commonly weathererl to a deptl of 5 to 8 and sometimes 10 to 15 feet. Beneath this yellow-brown zone, the body of the drift, like the Sllelbyville drift, consists of rather soft blute stony clay, with occasional beds of sand and gravel. The softness of the Wisconsin drift of the area is in contrast with the hardness of the underlying lllinoian drift. This may be due to the partial cementation of the older drift, or to its having been deposited beneath thicker ice, whose greater weight more effectually compresserl it.

I alley trains.-- Ialley trains were briefly referrerl to on pape 32 , in connection with the Illinoian glaciation of the region. Their development is worthy of more detailed consideration at this point, since remnants of valley trains of $1 \mathrm{Hisconsin}$ age, now terraces, are among the most conspicuous features of the micklle Illinois Valley (fig. 3).

When streams flow away from glaciers in valleys of moderate slope, they are commonly overloaded with debris derived from the ice, which they therefore deposit along their channels, building river plains of sand and gravel. Stch aggradational plains are valley trains (fig. 23).

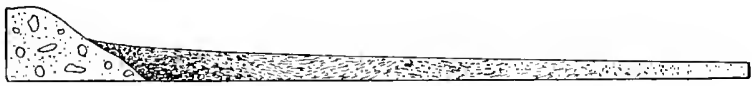

Fig. 23. lliagram of a valley train.

The stream deposits more and coarser material near the ice, and less and finer sediment farther from it. The down-stream slope of the valley train is therefore steepest near the ice, and increasingly gentle away from it (fig. 23). Snall streams greatly overloaded with very coarse material build valley trains of high average gradient. Larger streams less burlened with smaller material build trains of gentler average slope. Minor irregularities in the slope of the valley train and in the distribution of its material nay restlt from rapid wash from recently exposed drift covered tributary slopes beyond the ice front. This may incleed be a not unimportant factor in the overloading of the river, and the building of its train. The longer the ice edge from which the aggrading stream issues remains stationary, the greater the valley filling. Heavy deposits accordingly point to protracted stands of the edge of the ice.

Illinois River, as it issued from the ice sheet which at the Blomington stage of glaciation lay across its valley, probably presented an appearance not unlike the river shown in figure $2 t$, which is rapidly aggrading its channel. The waters of this stream flow in numerons channels which frequently meet and divide. Deposition along the floor 
of a given channel reduces its capacity. Presently the channel is nuable to hold all of its water, and a portion breaks over the side and follows a new line. The new channel hecoming choked, gives of $\mathrm{f}$ branches which in turn divide. The overflowing waters, following the lowest accessible lines of descent. may reninite only to separate once more a little farther down valley. By this process the river is broken up into many minor streams which are continnally shifting. Such rivers are braided rivers. The material deposited along different channels at any given time is likely to be of unequal coarseness, while that deposited at a given place at different times may vary within equal limits. This helps to explain the structure uf ancient valley trains, and of many other

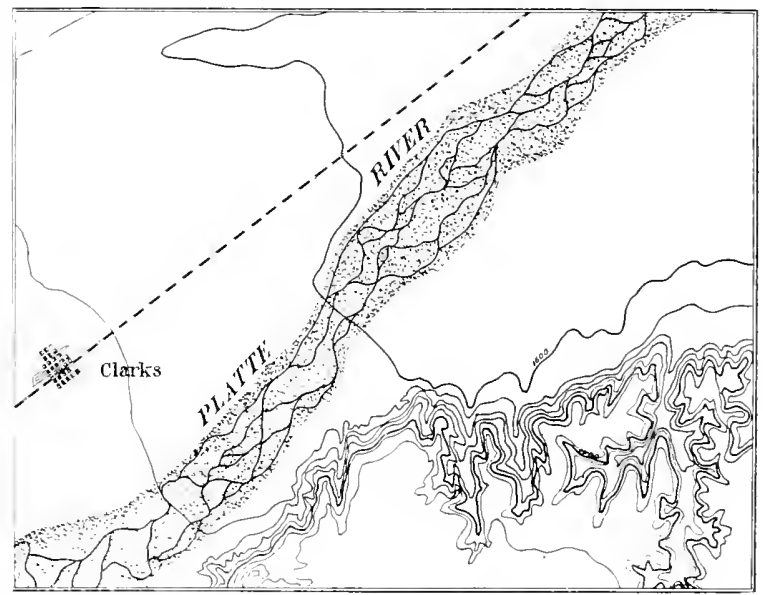

F1G. 24. Map of a braicled river. (Drawn from the Stromsburg tomgraphic sheet.)

stream deposits as well. The structure of valley trains is illustrated by Plate IX, and noy he stullied at the varions terrace sand and gravel pits scattered throughont the region. Lower Nlackinaw River, south of Pekin, is a braided strean.

Derelopment of terracs from ataley trains.-Following the withdrawal of a glacier from its valley, a stream may be relieved of the excess of load which led to the building of its valley train. Wash from the tributary slopes is likely to presently decrease also, as regetation secures a hold upon them, and tastens the surface material. If the stream finds itself greatly underloaded, it lowers its channel rapidly, developing a new valley in the aggraded floor of the old one, whose remnants constitute elevated terraces (fig. 25). Such a degrading 


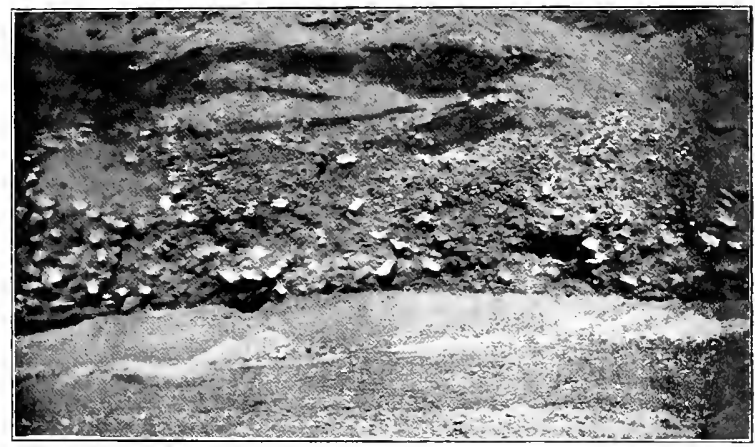

Exposure of material in a valley train, showing structure of beds. 

river lecomes less swift as the slope ot its chanmel becomes more gentle; finally its relatively sluggish current is turned against its banks, and sicle cutting increases as vertical wear liminisles. The terrace is narrowed where undercut by the river. and ma be cut into disconnected sections (fig. 26). Finally the valley train may be wholly removed.

If as the ice withdraws, the loal of the river is gradually and slowly reduced, so that it remains nearly loaked for a periorl, it may shift irom side to side of its vallev. While it slowly dexrarles its channel, and thus develops a series of terraces. This is illustrated in figure 27 , where a stream is supposed to have filled its valley with stratified rrift to the level A-13, and to occups a position near the left edge of its foom-plain.

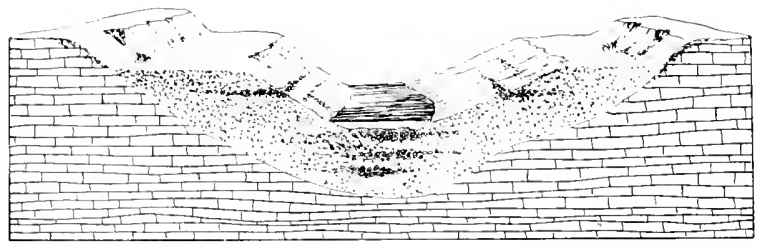

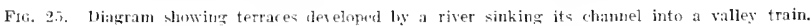

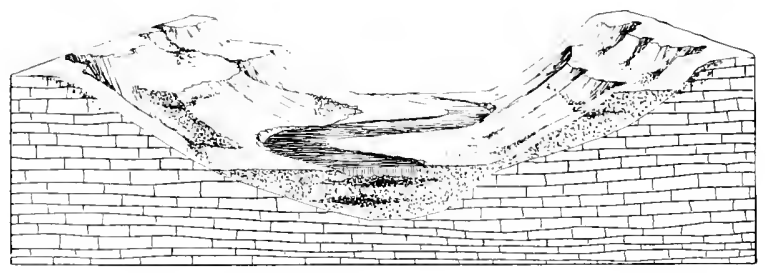

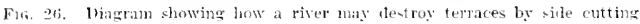

If the strean now shifts toward the opposite side of the valley, meanwhile degraming, it will presently occupy the position $C$. Should movement to the right stop there. becanse of contact witlo a projection of the old valley wall, or for some other reason, and the river return to the left sicle of the valles, a remmant of the old flood-plain, C-D-13, womld remain as a terrace. This terrace might extend a considerable dintance along the valley, or only a short distance. and its wirlth might vary notably. In similar maniner should the river fail to reach the left sile of its valley on the return swing, a terrace would result, as at E- $\mathrm{l}$. Many terraces at successively lower levels might restult from a continuation of this process. It is evilent that such terraces upon opposite sicles 
of the valley will not correspond in elevation, and that they may be destroyed wholly or in part by the widening of the flood-plain at a lower level. The top of the terrace C-D-P is an aggradational flat; the surfaces of the younger terraces at lower levels are degradational flats.

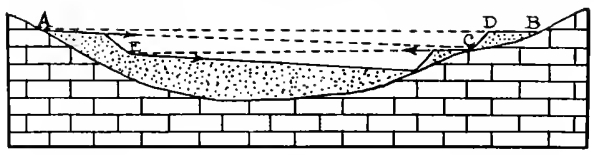

FIG. 27. Diagram ilhustrating develomuent of terraces by a slowly degraling river which shifts fron sile to side of its valley.

A somewhat different sequence of events was involved in the production of the terraces shown in figure 28 . The valley was filled with stratified drift to the level A-B. Subsequently the river cut a new valley in the drift filling, leaving terraces at $\mathrm{A}$ and $\mathrm{B}$. Later the stream was forced to again aggrade, possibly by a return of the ice to its upper course, and filled the new valley to the level $C$-D. Still later the stream

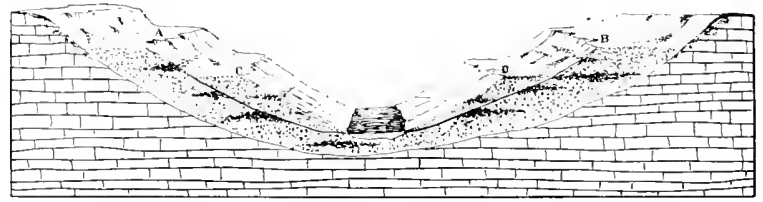

Fif. 28. Diagram showing two sets of teraces developer from aggradational flats.

again degraded its channel, leaving terraces at $\mathrm{C}$ and $\mathrm{D}$. The case here suggested would have been complicated had the river at either or both periods of erosion, degraded slowly while swinging from side to side of its valley, instead of entrenching actively.

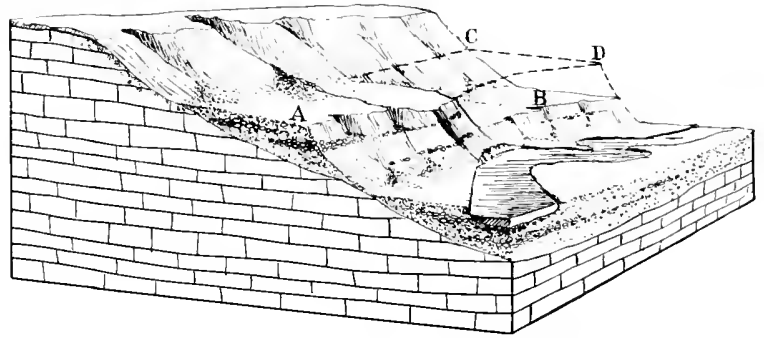

FIt. 29. Diagr:am to illustrate relations of terraces of unequal height to one another. 
The terace $A$ in figure 29 is clearly oller than the lower terrace $\mathrm{B}$. The ice edge may have lain across the valley at the upper end of $A$ long enough for the issuing waters to fill the valler to the level of $A$. If the ice then withdrew from that position, and halted farther wp valley, the extra-glacial waters may have fillerl the valley to the level B. Or, aggrading its valley to a level higher than B at the second stand of the ice, the river may subsequently have removed the deposits to that level. If at the first stand of the ice, its elge lay across the valley above the present head of the terrace $A$, that terrace of course extendeil to the ice front. It rose up valley and must therefore have been well above $B$, at $\mathrm{C}-\mathrm{D}$. The surface $\mathrm{B}$ may have been formed, in this case, by legradation from the surface $\mathrm{C}-\mathrm{D}$, or, wearing its channel below I: the strean may subsequently lave agsraded to that level.

The teraces along the Illinois, lescribed below, afford illustrations of the principles suggested above.

Outzeash from the ice edge at Peria.-The grcatest filling of Illinois Valley, judging by existing terraces, occurred at Peoria. A part of the upper section of the city stands upon a gravel terrace which is 170 to 175 feet above the river. The constitution and structure of this terrace are shown in nearly a score of gravel pits, and in numerous other exposures. It appears to have been formed at the Bloomington stage of glaciation. This is suggested by the fact that it coincides in elevation with the lower end of a valley train of similar composition along Farm Creek on the east side of the river, which is known to head in the Bloomington moraine. A remnant of the Farm Creek valley train may be conveniently seen in a pit in East Peoria, on Pekin Avenue, where 20 to 25 feet of cross-bedded sand and gravel are exposefl. Both terraces nearly fill shallow valleys that were cut in the Shellyville till before the Bloomington advance of the ice.

The stratified drift of the upper terrace at Peoria is covered, at least in places, by a few feet of till. This points to a slight temporary advance of the ice front beyond its main position in the northern part of the city, just prior to its final withdrawal. The ice appears to have pushed out over a part of the terrace before this, judging from an exposure above the Chicago and Northwestern Railroad tracks south of the mouth of Dry Run, where a bed of till containing large bowlders occurs within the stratified drift. This illustrates the fact that an essentially stationary ice edge often shifts within narrow limits.

The surface of the terrace slopes gently toward the west. Apparently the aggrading stream was withdrawn from a position along that edge of its flood-plain before its channel was filled. This abandoned channel appears to have subsequently guided the rum-off from the uplands to the west, determining the peculiar course of Dry Rum in the northern part of the city. Flowing south for about + miles, it turns sharply to the west on the inner edge of the terrace and joins the Kickapoo, instead of continuing south to the Illinois. Such abandoned terrace channels appear frequently to control the courses of minor streams. Crow Creek. 
west of Henry, and the creeks on the inner edge of the Hennepin terraces, are examples. Jyers Lake, on the inner edge of a terrace east of I'ckin, that is nearly 100 feet above the present river, represents an abandoned section of the terracing strean. I sinilar lake (Goose Lake) formerly existed along the lower inner edge of the middle terrace at I'coria, Eklerly people report skating upon it in their youth.

The upper Peoria terrace is 259 feet above the rock floor of the preglacial Illinois River. and as noterl above, about 175 feet above the present river. This recorls valley filling to a depth of 259 feet before the retreat of the liloomington ice, and excavation since to a lepth of 175 feet.

The highest terrace at Pekin has a general elevation of $520-5.30$ feet above the sea. (iravel beds occur at about 520 feet. the material at higher levels being sand. This has been blown hy the wind into sand hills which reach an elevation in places of 550 feet or more. The 520 530 font terrace appears not to represent the full height of valley filling here at the time the upper terrace at Peoria was formed. (1) It would involve a decline of surface of 70 to 80 feet in 10 miles, and of only 20 to 30 feet in the next 50 miles. where at the mouth of Sangamon River, Wisconsin gravels are reporter to have an elevation of 500 feet. This seems a rather improbable gratlational slope. though not an inpossible one. (2) A valley train of Mackinaw River which heads in the Bloomington moraine has an elevation of 550 feet where that valley joins Illinois Valley some miles below Pekin. The reduction of the upper Pekin terrace from its supposed higher level occurred subsequent to the withdrawal of the ice elge from Peoria, and it may have carried the valley Hoor below the present upper terrace level. In that event it was probably built up to the present level when the ice edge stood near Chillicothe, as noted below. In the process of lowering its valley floor from the level of highest filling, the river probably undercut and steepened the bluffs east of Pekin; slope wash has since reduced them slightly, spreading clayer material over the inner edge of the sandy terrace plain.

Filling of tributary adley's. - The effect of deposition by the Illinois upon some of its tributaries occupying valleys in the Illinoian drift, is worthy of note. Nong Lamarsh Creek, opposite Pekin, there are terace remnants at $\$ 10-520$ ieet. which are being undercut in places by the stream. Here it may be seen that the terrace material is laminated clay. The very thin horizontal layers (lanine) are variable in color, oftenest chocolate or dark purple. Occasionally stones of some little size are emberlited in the clay. The strutcture and composition of the material inclicate that it was deposited in the quiet waters of a lake or pond, rather than in ruming water. The material with which Illinois River rapidly filled its valley near Pekin acted as a dam across the mouth of Lamarsh Creek. whose lower waters became essentially stationary. The stagnant waters of the ponkled stream were able to transport fine silt only. In the winter season, bowlders were sometimes frozen into the ice that formed in the shallow waters near the 
head of the stream, or fell upon the ice from the valley sides. Later, such bowlders were floated down stream by ice blocks, and dropped on the silty botton.

Since the laminated clays noterl above occur at the level of the present stream, it is evident that a valler developed a ter the withdrawal of the Illinoian ice from the locality, and before the advance of the Bloomington ice to Peoria, whose bottom was at least as low as that of the present valley. And because the highest existing terrace levels are 80 to 90 feet below the adjacent uplands, the erosion accomplished between the Illinoian and lbloomington stages of the Glacial period appears to have been consideralily greater than that accomplisherl between the retreat of the Bloomington ice and the present. It should be noted in this connection, however, that since the 520 to 530 -foot level east of Pekin seems not to represent the extent of valley filling there, the 510 to 520-foot level along Lamarsh Creek probably does nut indicate the extent of filling in the tributary valley.

Outarash from the ice edsc near Chillicothe.-The constitution of the valley drift near Chillicothe appears clearly to indicate a stand of the ice edge at that point. In a railroas terrace pit about a mile north of the town 25 feet of rudely bedded sands and gravels are exposed. These beds are exceptional becatse of the many large bowlders which they contain; humdreds of bowlders 2 to 5 feet in diameter are scattered over the floor of the pit, while a few are 8 feet or more in cliameter. So numerous are these bowlders that the Atchinson, Topelia, and Santa Fé Railroad Company abantoned the pit, opening a new one over a mile to the sonthwest, whete fewer of them have been encountered. No material approaching in coarseness that at Chillicothe is found up the valley until the great hend is reacherl. This seems to indicate conclusively the presence of the ice front when the Chillicothe beds in question were deposited. Nany of the bowlders appear too large to be handled by the river, and it has been suggested that they were dropped directly from the overhanging ice. Occasional large bowlders are found down the valley nearly to Nossville on the west side of the river. and beyond Spring Bay on the east side. These may have been floated out from the front of the glacier by blocks of ice, and subsequently lowered to their present position near the river bank by the removal of the fine material with which they were associated.

The valley was filled in the vicinity of Chillicothe at least to the present level of the highest terrace, 550 feet. Elevations on the terrace above this height are thought to be due entirely to wind work. A well defined 550-foot flat, probably to be correlated with this. occurs on the opposite side of the river, sontleast of Spring Bay.

Possible outzush from the ice edge near Honry.-It is possible that the edge of the ice was stationary for a time across the valley a short distance north of Henry. Terrace drift in the form of cross-beddect sand and gravel occurs at Putnam at an elevation of about 550 feet: the highest terrace gravels noted north of this point reach but 535 feet 
east of De Pue and 525 feet northeast of Hennepin. If, atter the devedopment of a 550 -foot agsrarlational plain in the vicinity of Henry, the ice withdrew and halted farther up the valley only long enough for its issuing waters to build a plain to the level of 525 to $535 \mathrm{feet}$, the present relations would be bronght abont. As indicated in the discussion of figure 29, however, the observed facts may be explained otherwise. The upper Henry terrace nuy be a portion of a plain developed beyond the edge of the ice when the latter stoud above De Pue, the upper portion of the plain having been eroded subsequently to the level of 535 feet. No record of a stationary ice front at Henry is preserved by morainic ridges on the adjacent iplands.

The upper terrace at Lacon is probably to be correlated with the upper terrace near Henry. Both show by their topography that they are considerably older than the next lower terrace: their surfaces, originally essentially flat, are now quite undulatory, while the 490 to 500 foot terrace is practically unmodified.

Onta'ash from the icc cdge east of De Pue.-Evidence of outwash from a stationary ice edge near the eastern margin of the Hennepin quadrangle is much clearer than at Henry. (1) No well defined terraces appear on the topographic maps to the eastward which reach within less than 60 to 70 feet of the 530 to 540 -foot terrace near De Pue. (2) Large bowlders comparable to those at Chillicothe, occur in the valley drift. It is true that the majority that are exposed are at low levels near the river, but they may have been lowered to that position by removal of underlying finer material, as sugrested for those south of Chillicothe. (3) The teminal moraine shown on figure 20 , at " $\mathrm{C}$," registers a halt of the margin of the ice at this point.

As suggested under the preceding heading, the 530 to 540 -foot terrace may not represent the full extent of valley filling at this point.

Outadsh from points beyond arca of report.- It is doubtful whether the middle Tllinois Valley was agrarled by outwash from the ice when the several moraines which cross the upper lllinois (fig. 20) were deposited.

No terrace above 460 to 470 feet is shown on the topograplic map below the moraine at Utica. The 460 to 470 -foot terrace appears to extend some distance above the moraine and therefore to have been formed at a later stage. Terrace remnants at 460 to 470 feet occur within the area of the bulletin from Hennepin to Pelin. Their surfaces seem to be degradational flats, as noted below.

Leverett has foml evidence of a lake-like expanse of waters having existed hetween the moraine at Ltica (fig. 20, at "D") and the ice front at Marseilles. and later between the Marseilles moraine (fig. 20, at "E") and the ice edge beneath which the Minooka Ridge (fig. 20, at "F") and the Valparaiso moraine (fig. 20, at "G") accumulated. The debris from the ice sathered in these basins, whose overflow down Illinois Valley was loubtless nearly free from detritus. Erosion, rather than deposition, would therefore appear to have been in progress at these stages in the midlile and lower Illinois Valley. This erosion is referred to below. 
Deielopment of the loa'er terracs. - The surfaces of the lower terraces shown upon the topographic maps of the area are probably degradational flats that were developed by the river in accordance with the principles suggested in connection with figure 2\%. The development of these levels in the southern part of the area may have begm while the river was depositing nearer the ice which still covered the northern part. Their development throughout the area proceeded steadily dur.. ing the presence of the ice in the tpper Illinois Valley, as noted under the preceding hearling. The lowest terrace remnants, 460 to 470 feet, occur as already indicated at intervals from Pekin to Hennepin and beyond. These are thought $(p .48)$ to represent the level of the floodplain at the time Illinois Valler became the outlet of Lake Chicago.

The Chicago Outlet. - The withdrawal of the ice to the northeast of the site of Chicago meovered the lower end of the basin now occupied by Lake Michigan. lietween the receding ice front and relatively high ground to the south and west, in part that of the Valparaiso moraine. glacial waters gathered to form Lake Chicago (fig. 20). The area of the lake increased with the continued recession of the ice sheet, and at one time greatly exceeted that of Lake Michigan. Lake Chicago discharged along the line of Illinois Valley to the Mississippi and the Gulf $f^{1}$, the overflow constituting a river of great volume, estimated to have had a depth of 25 to 30 feet.

This powertul stream carried on more vigorously the work begun by its smallet predecessor. It degraded its channel rapidly where it found weak material, and more slowly where resisterl by strong rocks. Above Itica, where the river was flowing in a glacial valley, it encountered bet rocks of varying strength. On these it developed a relatively high, but irregular profile, steeper where the rocks were resistant and gentler where they were weaker. In the area considered in the report, only the drift filling of the preglacial valley was found, and the river lowered its channel, Prof. Cooley estimates. some 30 feet below the present valley botton, developing a very gentle gradient.

Given time enough, the Ottlet river would have worn the rocks of its upper channel to a uniform and gentle grarle, continuing that of the lower valley. When this task was only well begun, the retreating ice sheet uncovered a lower outlet for the lakes, and the Chicago outlet was abandoned. Had the Chicago Outlet river completed its work, the Great Lakes, save Ontario, would now have Itlinois River, rather than the St. Lawrence, as an ottlet. In that case the midrle Itlinois Valley would lack the characteristic features that have developed because of the inability of the present stream to carry on the work of its predecessor.

The condition of the middle Illinois Valley when it first received the discharge of Lake Chicago is uncertain. It has been suggested that the

1 A writer stated in 1,89 that Lake Michigan once discharged to the southwest: "Appearances justify a belief, that Lake Iichigan, at an early perind, found an outlet into the lilinois, through which the Great Lake waters made their passage; there being evident water-worn traces on tbe banks of the lllinois, which indicate that it formerly was the chamel of far more abundant waters: and on the horders of the lakes, that the surface of their waters was once several feet higher." Dana, E., Geographical Sketches on the Western Country, p. 151, 1819. 
bottom of the valley at Hennepin was at an elevation of about 400 to 500 teet. This view is opposed by the existence of terraces below the level indicated. These terraces were not formed by present Illinois River which (as indicated on page 53) has built up the floor of the Outlet river only to the level of the present flood-plain, and the Outlet river, on the otlier han!, does not appear to have been a strean which degraded leisurely as it swung from sirle to side of its valley, thus developing terraces. Its waters seem to have covered the entire area of the present bottons, and it probably steadily lowered this entire belt to the low grade noted above without developing any internediate flat. It seems not inmprobable that the valley botton had been eroded to the level of the +60 to 470 -foot terace already described, before the advent of the lake waters. In this event, and accepting Cooley's estimate of the anount of filling that has occurred since the lake waters were withdrawn, the Outlet river lowered the bottom of the middle valley 55 to 60 feet. The vigorous erosion of the Outlet river is reflected in its steep banks. These have suffered least modification where formed by the till of the valley wall, and such sections of the bluffs are in general steeper than those behind the terraces.

Having developed a very gentle slope, the lower Outlet river must presently have conse to meander, pushing back the sicles of the valley and extending its flat. This would have invited the final destruction of all the terraces. It was prevented only by the early withdrawal of the lake waters.

The terraces remain for the most part in positions somewhat shelteref from the attacks of the river. The Hennepin terraces have a protected position on the inner side of the great bend. The other large terraces, with the exception of those near Henry, occupy expansions of the valley immediately down stream from defenling projections of the valley walls.

That the Outlet river was of great volume compared with its tributaries is indicated by the fact that the width of its channel increases very slowly lown strean.

If isconsin loess. - The $1 \mathrm{Visconsin}$ drift of the area received a partial covering of loess, which, in its typical development, closely resembles the Iowan loess, describer on page 3t. It has been removed from many erosion slopes. and inland gives way to the black earth of the upland prairies. Plate $X$ shows a typical exposure of loess at the mouth of Hicks' Hollow, southwest of Chillicothe. The loess (or loesslike silt) mantle has an arerage thickness of 2 to 6 feet, though in numerous places it reaches 10 to 14 feet. The bulk of the thicker deposits is a buff-colored calcareous silt, often containing many lime concretions (Pl. VIII I;) and shells of mollusks. The weathered surface zone, 2 to 4 feet in depth, is hrown and leached of its limy constituents. This phase, a brown clayey earth, is that generally seen oret the upland. Thanks to its presence, the surface of the Wisconsin drift is generally free from stones.

The origin of the Visconsin loess is in rloubt. The fact that the surface of the till beneath the thicker loess is unleached. seems to indicate that its accumulation began rather promptly upon the disappear- 


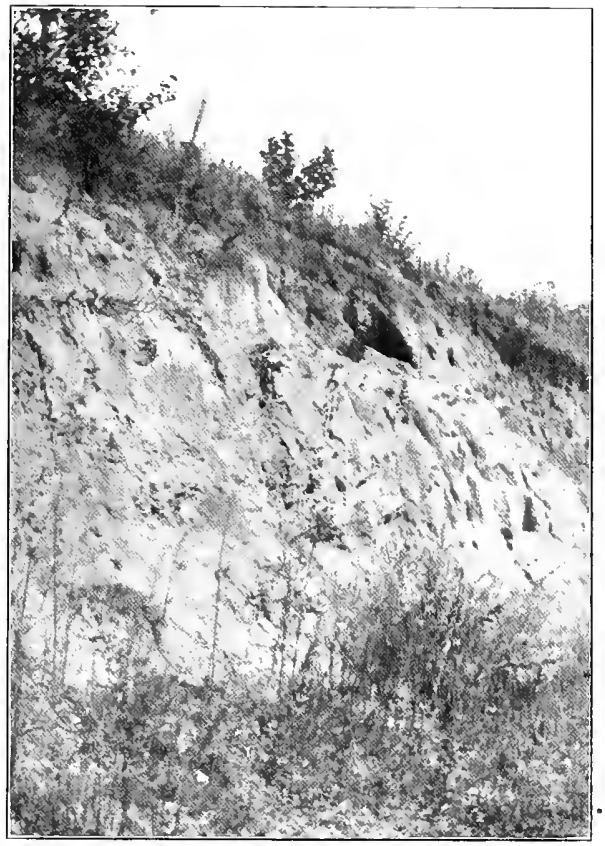

Exposure of loess at mouth of Hicks' Hollow, southwest of Chillicothe. 

ance of the ice. Westerly winds miglt be expected to bring fine material in quantity from the loess covered Illinoian srift plain. The Iowan loess, however, had been leached to a depth of several feet before the advent of the Wisconsin ice (as indicated in the discussion of the section given on page 27 ). Wind-blown material from its surface should therefore be non-calcareous, whereas much of the Wisconsin loess is highly calcareons. This demands another source for at least the major part of the $\mathrm{W}$ isconsin loess. As indicated above, the drainage from the Shelbyville ice edge is known to have been generally feeble, and stuch may have been the case in places from the Bloomington ice, though along Illinois Valley the gravel deposits imply vigorous outwash. Silt washed out from the ice by sluggish waters might subsequently have been carried back over the body of the drift by the prevailing westerly winds. The surface of the IVisconsin till sheet itself may have been an important source of loess, before it was covered with vegetation. A possible source for some of the loess-like silt is found in the work of earthworms. These animals are continually bringing large quantities of fine material to the surface. This is only a minor source, for otherwise similar sitt should appear over wide areas where absent.

The loess has probably been subject to much redistribution, as shown by its occurrence on certain lower erosion slopes developed in the Wisconsin drift. 


\section{CHAPTER IV.}

LOST-GLACIAL CHANGES.

\section{INTRODECTMS.}

Since the finat withlrawal of the ice theet, the drift-covered surface of this area has heen exposerl to the chemical and mechanical action of the atmosphere, to the worts of ruming water, and to influence of various forms of life. It should not he assumed that the changes discusser in this chapter as post-olacial all touk place after the final recession of the ice sheet from the ['nited States, or even from Illinois. The changen affecter in any given place hy air and water began as soon as that place was alandined by the ice. The latest stage in the levelopment of the region has accorlingly been of very unequal length in its different parts. It has molnably heen several times as long in the area of the Illinoian drift as in that cosered by the Wisconsin ice, and has been much longer in certain parts of the latter area than in others.

The changes wrought by the Chicago Outlet river might be considerer as post-glacial. Since the very existence of the (utlet river was dependent upon the rre-ence of the ice to the northeast. however, it has heen discusued in the chapter on the lilacial period. The work of the minor streanis is discussed for the most part in the present chapter, though it began in the southem part of the area while the ice still occufied the nuthern part and was influenced for a time throughout the area lo that of the Outiet river.

\section{ConitTONS AFFETTR Fosion.}

The freshly expmed drift surface fumished conditions of erosim liffering in inimutant ways from thuse of the present.

The streans, even asile from the glacially swollen Illinois, were doubtless of much greater volume than at present. The vast ice sheet to the untheart chilled the westerl! winds, and probably compellet then to relinguish much moisture which otherwise would have been carrier farther east. This influence of the ice doubtless extended mans miles west of its elge. Slope wash and stream transportation were also greatly favmerl by the loose character of much of the surface material, and by the alsence of protecting vegetation. Wind transportatim was favined hy the lack of vegetatim, but hindered by the rainfall and during the long winters by the fact that the frozen ground waters cementer the surface material into a compact mass. 
WIND WORK.

Wind work within the area under discussion has been largely transportation and deposition. Wind borne particles colliding while in transit, or blown with force against the surface of the ground, have doubtless effecterl some wear, and have been worn themselves. On the whole, however, wind wear (abrasion) appears to have been relatively' unimportant.

Strong winds often transport great quantities of fine particles the size of dust or loess long distances. Frequently raised by ascending air currents well above the ground, such material settes independently of surface objects, forming a layer of more or less uniform thickness. This may help to explain the distrilution of the loess, referred in large part to the wind in the preceding chapter.

Sand grains are too heavy to lie lifted much about the ground or to be carried far by ordinary winds. Sand, and sometimes even fine gravel, is rolled by the wind along the surface, however, or carried short

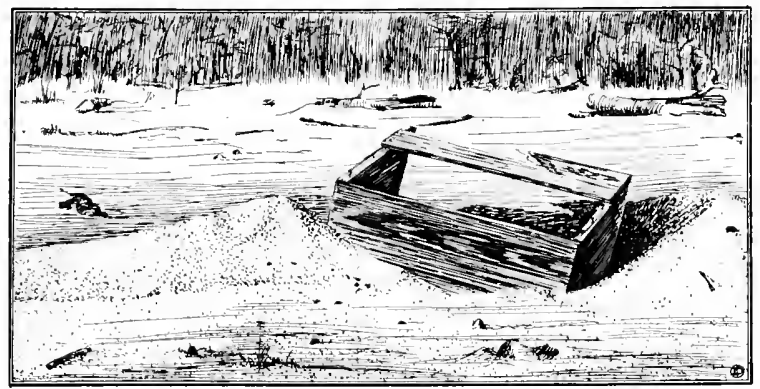

FIg. 30. Siket.h showing how wind-blown sand accumulates ahout an impenetrable obstacle. The wind which deposited the sand cane from the left. Lodgment against the box is prevented on both the winlward and leeward sides by wind eddies, (Sketched from photo by Bastin.)

distances. In these positions it is likely to lodge about obstacies in its path, forming mounds or ridges. Such elevations of wind accumulated sand are dunes. Dunes are extensively developed within this area, as indicated in figure 3 . Figure 30 suggests the manner in which sand begins to accumulate about an impenetrable obstacle. Once starterl, the hillock itself acts as a barrier to other sand, and so occasions its own growth. Where there are clumps of vegetation, they may likewise intercept drifting sand, and cause the formation of dunes. The way in which sand gathers in and about vegetation is frequently illustrited along the thick-set osage orange hedges of the terraces where the major deposit is on the leeward side. 
The dunes range in height from a few feet up to 30 or 40 feet or more above their immediate surroundings. Commonly in the form of irregularly roundish mounds, they are sometimes relatively long and narrow ridges. This is the case locally north of Hennepin and south of Spring Bay, where the ridges extend northwest and southeast. or at right angles to the prevailing southwest winds. Figure 31 shows a typical dune in cross section. The longer and gentler side faces the dominant wind, and serves as a roadway up which sand is carried and

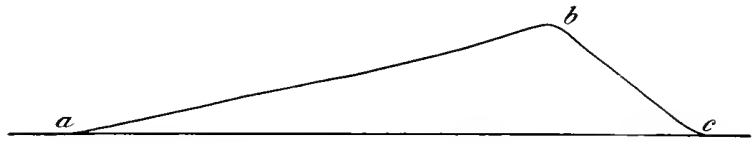

Fic. 31. Cross section of a sand dune. The gentler (ab) slowe is the windward side wf the dune; the stepier (bc) slope, the leeward side.

rolled to the crest, where it falls down the steep slope. The windward slope tends to adjust its steepness to the strength of the wind. Wexk: winds, especially if handling coarse sand, require a gentle grade; strong winds, particularly if favored by fine sand, can carry their load up a steeper slope. The leeward slope is limited in steepness by the anyle at which the material will lie. Since the direction of the winds frequently changes in the region here considered, the dunes are generally much less regular in form than shown in figure 3I.

If, as often happens, the wind is able to move more than it is carrying when it begins the ascent of a bare dune, it removes sand from the lune surface and rolls or carries it to or toward the crest. By the continued transfer of sand from the windward to the leeward slope, the dune slowly shifts its position. It is evident from the nature of this misration that only an extremely small percentage of the sand is in motion at any given time. I'late XI, A shows a dune that is slowly advancing into Mleyers Lake, near Pekin.

In certain of the dune areas of the region, notably near Pekin and Chillicothe, basin-like depressions among the dumes are quite as distinctive of the topography as are the elevations (Plate XI, B). Such depressions may result from the wind scooping out the sand, or from more sand leing depositerl around than on a given place, which therefore comes to stand below its surroundings. In a few cases, also, dunes appear to have invated shallow ralleys, whose unfilled portions remain as depresions without outlet. Locally the dune topography of the area rather closely resembles terminal moraine topography (fig. 22); the constitution and structure of the hilis will enable the student to readily distinguish between them.

While most of the dunes are confiner to the terraces from which their sand was derived, a few have migrated to the eastern bluff slopes and uplands, where they appear at intervals all the way from Pelin to Hemnepin (fig. 3). They are confined to the eastern biuffs because the 


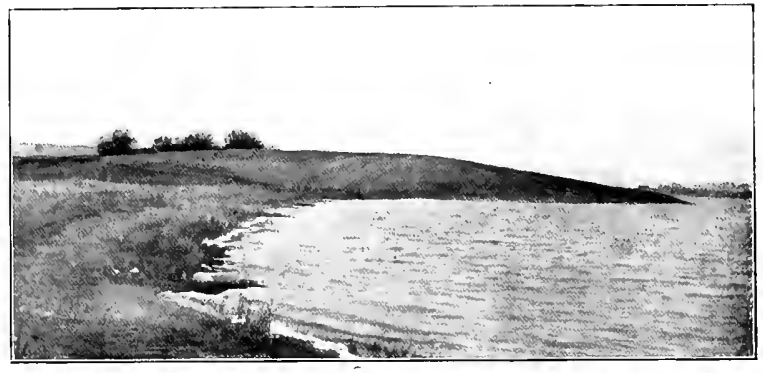

1. Sand dune adrancine into verers Lake, near Tekin.

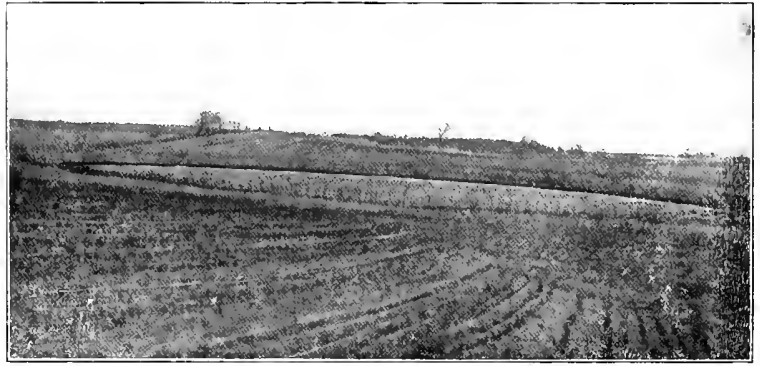

B. Depression in windblosm sami near l'ekin, containing pond. 

prevailing winds are from the west. On the west side of the valler the winds blow from the uplands to the sandy terraces, while on the east side they blow from the sonrce of the sand to the uplands. The dunes along the eastern bluffs are best leveloped hack of the terraces. This may mean that the bulk of the upland dune sand was carried there after the partial removal of the valley drift. In that event it would apparently illustrate the importance of the factors that at first inhibiter the work of the wind (p. 50 ).

There is much sand along the hases of the steep bluffs opposite Henry and Chillicothe, some of which appears to be wind lodged, that is not aggregated into distinct dunes. The steepness of these slopes would, apart from the existing vegetation, possibly prevent the sand reaching the uplands. Winds can carry sand to any height up gentle slopes, but are unable to carry it up verv steep slopes. The lune areas of the region are in general under cultivation.

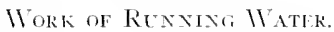

\section{POST-GLACIAL AGGRADATION BY ILLINOIS RIVER}

The transporting power of a stream is dependent upon its velority, which in turn is controlled by its gradient, volume, load, and the shape of its channel. The influence of a high gradient and of great volume is evident: both invite rapid flow. The load which a stream transports reduces its velocity, for the energy expended in moving the cletritus would otherwise be available for flowing. Lastly, a stream is retarded hy friction with its bed and banks. The greater the cross section of the channel, and the more irregular and crooked the berl, the greater the amount of energy expended in overcoming friction.

The Chicago Outlet river, because of its great volume and the fact that it left the lake essentially free from sediment, was able to reduce its lower channel to an extremely gentle slope and still carry away all the material brought to it by tributaries. When the discharge from the lakes was withdrawn from the Chicago Outlet, Illinois River was suddenly reduced to a small fraction of its former volume. This reduced its velocity and hence its carring power to such an extent hat in the section of low slope helow Itica it was unable to transport the material delivered by its tributaries. This detritus was accordingly dropped along its valley floor, together with that derived from its upper course, where a steeper gradient enabled the river to continue, though much more slowly, the erosion of its predecessor. The amount of post-glacial filling along the middle Illimois has been estimated by Cooley to average 30 feet. The result of this filling is the present floniplain.

By aggradation a river tends to develop a steeper grade, along which it may wash its load. If the post-glacial Illinois has built up it valley bottom 30 feet, it is remarkahle that it still has an average fall of only a trifle over four-fifths of an inch per mile between Hennepin and Pekin. It is difficult to see how even the Outlet river could have developed 
so low a gradient. The steepening of a river slope, so far as it is due to deposition, of course depends upon more rapid deposition in its upper than in its lower part. Possibly the failure of the lower lllinois to appreciably increase its grade is to be explained in part by relatively large contributions of sediment from its lower tributaries. It has been suggested that the northern part of Illinois Valley may have been depressed. The great weight of the jce sheet has been thought to be a possible cause, while the heary deposits of drift may have prevented a complete return to the former attitude after the disappearance of the ice. Such a movement was suggested by the fact that deep borings apparently showed the rock floor of the pre-glacial Illinois Valley to be as low at Princeton and Hennepin, as at Peoria, 50 miles down stream. It is by no means certain, however, that these borings discovered the lowest point in the ofl valley. It has heen further suggested that the low slope of the lower Illinois may not be due wholly to erosion by the Outlet river, but in part to the suspected movement. The last suggestion seems hardly applicable, since the downward movement, occuring before the Outlet river came into existence, could affect only the slope with which the river began its work, not that which it subsequently developed. To explain in this way the present low grade of the river, very recent movement must be assumed.

The history of the Illinois flood-plain, already referred to, is in contrast with that of normal valley flats. As an eroding river approaches base-level, its diminishing gradient compels it to flow less and less swifty. Finally the sluggish current is diverted by the deposits or currents of tributaries and by various obstacles from the relatively direct course maintained during its more vigorous youth. Striking its banks at various points, it cuts them back. The points of attack shitting from time to time, the flat is widened generally, and a flood-plain is developerl upon which deposits may subsequently be made by the stream in periouls of overflow. Thus flood-plain flats are ordinarily developed first and primarily by lateral erosion, and secondly and subordinately, by deposition. The Illinois flood-plain. on the other hand, is the product of deposition upon a flat not forned by latera! erosion. Its width is essentially that of the Outlet river, which, as we have seen, had not begun to meander when its career was cut short. To be sure, aggradation by the present stream has slighty increased the width of the valley bottom, since any valley whose walls are not vertical is wider at any level than at any lower one. The present river may also have undercut its bluffs locally to slight extent.

Normal valley flats are widest in their lower portion, where the gentle gradient that invites lateral shifting was first formed, and narrow somewhat regularly up stream. The irregular width of its valley was of course inherited by present Illinois River. The constriction at Peoria is probably due to the moraine which crosses it at that point The cause of the relatively narrow sections near Lacon is not apparent. They may be due to the influence of resistant rocks, though this is not demonstrated. In the western bluffs, bed rocks are thinly covered with 
drift, as indicated by outcrops and by numerous coal drifts. There is, however, no evidence of their presence in the opposite eastern bluffs. The very striking narrowing of the valley in the vicinity of the great bend is explained by the lesser age of the narrow section. Below the bend the river is within the great Rock-Illinois pre-glacial valley; above the bend it follows (Leverett) the course of a small pre-glacial tributary which headed near Utica. Furthermore, at Marquette, and on the opposite side of the valley near Mud Lake, relatively resistant bed rocks appear in the bluffs and lower ravine slopes.

The structure of the flood-plain deposits, and the incipient levees of the river were described in the first chapter.

\section{FLOOD-PLAIN LAKES.}

The lakes of the middle Illinois flood-plain range from small ponds to large bodies as Lake Senachwine (fig. 9) which is over 4 miles in length. Like many of the other features of the valley they appear to differ somewhat from the ordinary representatives of their class. Plate XII, A and B may illustrate the usual manner in which floodplain lakes are formed. Such a meandering stream tends to erode along the outer edge of its curves, where the current is relatively swift, and to deposit on the inner edge, where the water is slack. Finally the stream cuts through the narrowing neck of land between the two limbs of a meander, as shown in the mirllle distance of Plate XII, B, at "A". The current abandons the old round-alout course, which is likely to be isolated by the shifting of the stream to another position upon its floodplain, or by deposition at the ends of the abandoned meanter, whose standing waters check the edge of the current. Such lakes are usually crescentic in form and are called or-boz' lakes. In the summer of 1907 an ox-bow lake was forming in the lower course of Kickapoo Creek. A number of them may be seen along the lower Mackinaw, where the formation of others appears imminent. The lakes of the Illinois floodplain are clearly former sections of the river, but they have not the curved outlines of typical ox-bow lakes. Lake Senachwine, shown in figure 9, is a striking illustration of this. The river appears to have broken from its partially filled channel in flood time, to follow a slightly lower line through the adjacent bottoms. Since there are many lakes upon the flood-plain, numerous changes in the position of the river are recorded. The fact of frequent shifting was seen in Chapter I to be indicated also by the structure of the flood-plain.

The lakes are being gradually obliterated as indicated on page $(1,11)$ by the encroachment of marsh vegetation upon their shallow borders, (2) by wash from the surrounding land, and (3) by wind-blown material. Many of them probably retain but a small fraction of their original size and all are temporary features. Doubtless many former lakes have been destroyed and the existing ones will be replaced by others in the future unless the river is artificially confined to its channel.

The lake-lilie expansions of the river itself were explained in Chapter I. 
The "pportunities along the midule Illinois for the study of valley development are unsurpasserl. Tributary valleys are crowded together on both sides of the river. Attention is now directed to their history. Xany of the processes involverl in their formation have been discusserl in other connections in precerling pages.

The beyinniny of the z'alleys.-If the slopes learling to Illinos Valley at the withilrawal of the ice shect had been of uniform steepness and composition, and the rain that fell upon them had been everywhere equal, the run-off, and the quantity of earth washed down slope by the run-riff, would have been equal along all lines. Doubtless none of these conditions existed. The sopes were more or less irregular, and the run-off therefore uneven. Where more water descended, its velocity was greater and it eroded faster than elsewhere, forming a depression. The surface materials of the slopes varied from point to point in size and compactness. Where the particles were small and not compacted, ther were removel more readily than at other places, the result being as before, a depression or yully. Gullies (miniature valleys) then, are depressions in the land begun by the erosion of running water in conserpuence of inequalities in slope or in material.

Plate XIII, A shows a typical gully. Water that in the future runs down slope into this sully will wear its head hack into the upland. Rain wash down it sides will widen it Erosion by water flowing along its buttom will deepen it. Gullies grown sufficiently long, wide, and deep are called ravines which in turn may grow into valleys.

The orivin of the strams. - A part of the rain sinks into the ground, which at a varying distance from the surface is full of water. The surface of this ground water is the a'ater fable. When the bottom of any ravine is worn helow the water table, water seeps into it from the sides, and would fill it to the surface of the water in the adjacent rocks were the water not continually flowing away as the stream. In addition, streams receive water that falls as rain on their surfaces, and that runs directly from the tributary slopes. All the permanent streams of this area, however, are maintained primarily by the issuance of ground water along their lower valley sides.

The position of the water table in not comstant. It rises during periorls of rain and falls in times of drought. Ravines whose bottoms are below the water table when it is high, but above it when it is low. contain intermitfent streams. Alost of the streams of this area are of this class. Furthermore, the small ralley which possess streams in their lower portions are without them near their heads, where they have not reacherl the water tal,le. Certain valleys, ton, which extend from the clay tpland across the Illinois terraces to the river, have permanent streams in the 1pplands, which wither and disappear on reaching the terraces. This is because the lowest position of the water table in the porous sands and gravels of the terraces is almost at the level of the river. 


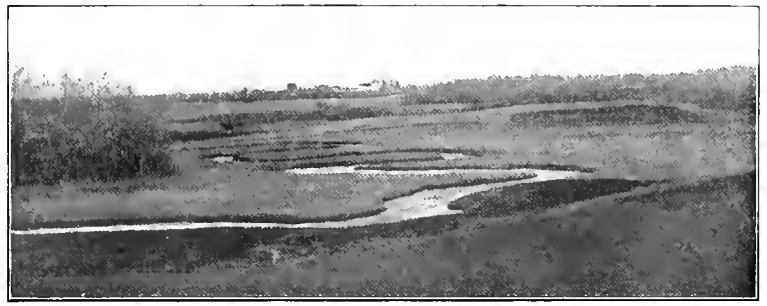

A. A meandering stream. (Photo by Neal.)

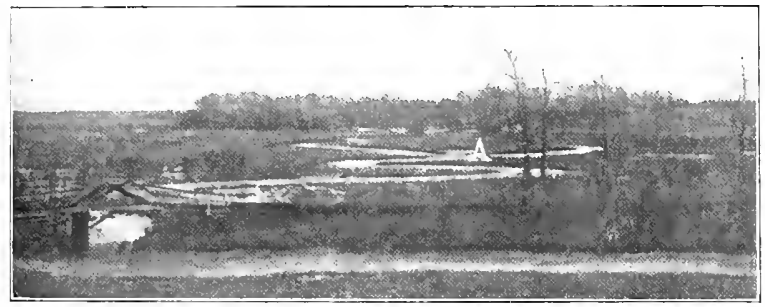

B. Menutering strean an ox-bow lake. (Photo by Xal.) 

Once a valley has acquired a permanent stream, it grows more rapidly than hefore in all dimensions, becoming steadily deeper, wider, and longer.

The decpening of the a alleys.-Since within this area the bottoms of most of the valleys are in drift, the smaller material along their stream channels is readily removed. Fine sediment is often carried in suspension by upward moving currents, formed by projections of the hed or banks. Somewhat larger material is rolled or dragged along the bottom. When bowlders too large to be moved by the current are discovered in the till in which the valley is cut, they must remain upon the floor of the channel until worn to a size within the capacity of the stream.

A few of the ravines of the area are floored in part with firm bed rock. Clear water has little effect upon such material, but the sand and gravel carried by the stream rub and strike the botton, and from time to time wear or break off bits of rock which are carried away by the current.

The fact has been pointed out in earlier connections that as a stream lowers its channel, erosion becomes slower, for the slope of the channel and in consequence the velocity of the current, are steadily reduced. Finally a gradient is reached below which the stream cannot cut. It is then said to be at grade. This represents a balance between transporting power and load, the slope being just steep enough to give the stream the velocity necessary to transport its load. It is evident that the slopes of channels at grade vary in steepness. Large streams with relatively little loads develop very gentle slopes before reaching grade. The Chicago Outlet river, discussed above, is a remarkable example. Smaller streams with relatively large loads find themselves at grade on steeper slopes. From this it follows that a given stream flowing over a slope without cutting or depositing may not remain at grade. If its volume is increased or its load decreased, it will cut to a lower and gentler slope, while if the opposite change in volume or load occurs, it will develop a steeper channel by deposition. There is thus a limit below which the small valleys of the region cannot be cut. At their mouths this is the level of the larger valleys to which they lead; upstream from this point is a gentle gradient to which no definite degree of slope is assignable.

Many small valleys have been cut with reference to an Illinois Valley terrace, rather than the Illinois flood-plain, as a base-level. Such valleys are of course less deep than those whose mouths are at the level of the river.

The zidening of valleys.-The development of a valley flat by the side cutting of its stream was discussed on page 54 , in connection with the flood-plain of Illinois River. Vertical erosion often continues slowly after active side cutting begins. This has led to the formation of terraces along many of the small valleys of the area. From the discussion of preceding pages it will be understood that such terraces are likely to be destroyed by side cutting at lower levels. While vallevs are ultimately widened chiefly by the lateral erosion of their streams (Pl. $\mathrm{XIII}, \mathrm{B})$, other processes aid that have been in operation from the be- 
ginning. (1) Each rain washes material down the sides. (2) Masses of earth sometimes slicle (slump) lown the sides of the valley. Slumping is particularly common with clay, which during heavy rains becomes both heary and slippery (T'l. Niv, A). (3) Naterial near the surface moves slowly down the sicle slopes by a process called creep. Earth particles expand uncler the heat of day, and chiefly down slope, for gravity assists lownwarl moventent while it opposes expansion up slope. When the particles cool they contract largely from their upslope ends and this again involves movement with, rather than against gravity. The result of many expansions and contractions is an appreciable movement toward the valley botton. When the valley sides are of clay, creep, is inviter in another way. As it lrys after rains the clay hinks and cracks, forming the familiar sun-cracks. Because of the influence of gravity, the opening of a horizontal crack is largely the result of the lown-slope movement of the clay below, rather than the up-slope movement of that above. With the first shower the clay swells and the crack is closerl. [ncler the influence of gravity it is closed chiefly from above rather than from lelow. Repeated shrinking and swelling means very slow movement down slope. The trees of almost every valley side within the atea lean down slope because of creep. The surface material creeps faster than that at a slight depth, tipping the trees toward the axis of the valley (Pl. XIV, B). (4) Minds nav blow the material from the sides of vallese, thus slightly increasing their width. Certain other less important ways in which valleys are widened need not be discussed here.

If the sides of a valley are of uncqual resistance, they will recelle at unequal rates and if they vary sufficiently, the valley may become wide in some places, while till narow in others. This is strikingly illustrated in the case of the lower Kickapon Valley near Peoria. The "Horseshe Bottom" has been opened in drift, while the notable constriction just below is in Pemsslyanian rocks.

There are limits to the width which a valley mav attain, just as there are to its lepth. These linits are set by the next valley upon either side. The widening of adjacent vallers may destroy the divide between them, however, the two then hecoming one. This possibility is illustrated near the right hand sicle of Plate $\mathrm{ST}^{r}$, A, where two gullies are rapilly consuming the narrow ridge which separates then. The larger gully formed by their union may in turn unite with the gully next to the lef: The final outcome uf this process among vallevs would be the reluction of the entire area to the level of the vallev floors.

The lengthening of zalleys.-This is not accomplished by the permanent stream which legin some distance below the head of the valley. All the other agencies which widen valleys tend also to lengthen them, rain wash being most important.

The valley head is carried back into the upland in the direction of greatest erosion, and this is letemined by the slope of the surface and by the character of the material. If the slope in which a valley heads is uniform and the material every where the same, most water will enter 


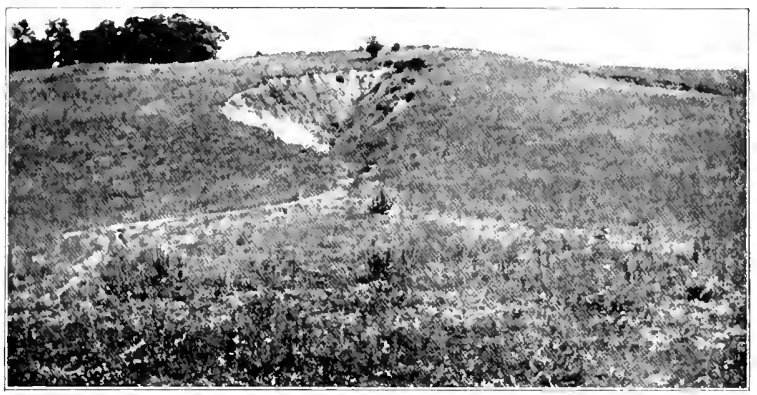

A. A young gully near Lacon. The material removed in the formation of the gully is spread upon the flat in the foreground, forming an alluvial far.

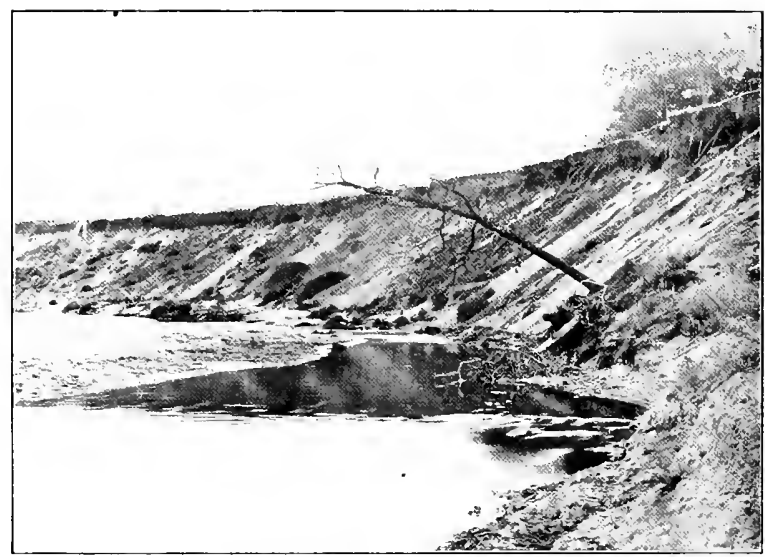

13. Crow Creek, west of Henry, widening its valley by lateral erosion. (Photo by Crane.) 

the valley from straight up slope and the valley will extend itself in that direction. Nore often minor irregularities of slope bring the major part of the run-off tributary to the head of a valley first from one direction and then, after a longer or shorter interval, from another. The line of least resistant material may also extend in different directions at different times. For these reasons the courses of most of the small valleys are irregular.

Peculiarities in the courses of certain valleys were pointed out on pages 43-44. Senachwine Creek (the one north of Chillicothe) also follows an interesting course. Instead of flowing east by the shortest line to the Illinois in the vicinity of Sparland, as might be expected, it flows south for several miles parallel to the main valley, and finally empties near Chillicothe. The explanation is found in the presence of a minor morainic ridge southwest of Sparland which extends roughly north and south. The Senachwine flows around this ridge to reach Illinois River. Morainic ridges also influence the courses of some of the streams shown on the Hennepin quadrangle. Big Bureau Creek flows south past Princeton along the edge of the Bloomington moraine; west of Tiskilwa a curve in the moraine turns the creek sharply to the east, to meet the Illinois at the great bend. The parallel courses of East Bureau and Brush creeks appear to be determined by minor ridges.

A valler ceases to grow by headward erosion only when stopped by rival drainage in the opposite direction. If the material upon which opposite flowing streams work is the same, the divide between them ceases to shift horizontally when the opposing slopes are of equal steepness. Thus the growth of any given valley within the area is limited in all three dimensions; in depth by the level of the valley to which it leads, and in width and length by rival valleys. A further point concerning the lengthening of the valleys in this area is worthy of note. All have been lengthened by headward erosion; some of those which are directly tributary to Illinois Valley have been lengthened also at their lower ends. When Illinois River, flowing at the level of one of its terraces, shifted toward the center of its valley from a position near the bluffs, it was followed across the flood-plain by the permanent streams that entered it on the side from which it withdrew. When the Illinois later lowered its channel into the flood-plain, forming the terrace, the extended tributaries were enabled to cut valleys in the terrace which differed from the older upland sections in several respects. They were of course less deep, and the streams preceded the valleys, all parts of which are of the same age.

Struggle for existence anong ravines.-It is not to be inferred fron the foregoing paragraphs that all gullies become valleys or even ravines. Quite the reverse is true. Few of the gullies shown in Plate XV, A, for example, can grow to ravinehood. As they widen, the intervening divides will be worn out, combining adjacent gullies and reducing the number. Some of the larger gullies are already invading the slopes above their shorter neighbors, thus capturing the run-off which otherwise would go to the latter, whose headward growth is likely to be cut short. Such a group of gullies may be entirely destroyed in the forma- 
tion of a single ravine, which will in turn presently find its growth contested w other ravines. Such a conflict is shown in Plate II among the ravines near IVesley. Little opportunity for growth remains to most of the ravines in the vicinity, and many are doomed to destruction by their more powerful rivals.

Tributary z'alleys. - Most of the small valleys of the area have tributaries. They began in the same manner as the parent valleys. If more water from the sides entered at certain points than at others because of inequalities of slope, it flowed faster and eroded more rapidly at such places than elsewhere, starting gullies. The same result was achieved if the material of the valley sides was less resistant along certain lines than along others. The first generation of tributaries usually developed tributaries of its own, and in many cases the process has been repeated a number of times.

Stages in valley development.-Since valleys increase in size as they advance in years, it has been found convenient to adopt certain terms descriptive of the several leading stages in their development. A voung valley is one that is still narrow and steep-sided; it is generally short and otten has a relatively steep bottom and poorly developed tributaries. A mature zalley is wider and deeper and longer; in cross section it has become $\mathrm{L}$-shaped, rather than $\mathrm{V}^{\top}$-shaped; its gradient is less steep and its tributaries more numerous and better developed. An old valley is shallow and wide, with a low gradient and gentle sloping sides. Corresponding terms are applied to regions as a whole. An area is in the youth ful stage of its development when its valleys are young, and extensive interstream areas are untouched by drainage lines; most of the work of reducing the area to base level remains to be done. An area is mature when thoroughly dissected with valleys, so that slope is at a maximum. Finally, an area is old when it has been reduced to a low, flattish plain, with broad, shallow, flat-floored valleys.

IVith the exception of the Illinois, the valleys of the area under consideration are all young, for they are all narrow and steep-sided. They represent various stages in youthful development, however, a fact clearly shown by Plate II. This is because some were begun earlier than others, and also because water was received from a larger area, and the rocks were less resistant in some cases than in others. The middle Illinois Valley may perhaps be taken to represent late maturity; so far as the wirlth and slope of its flood-plain are concerned it is old, but the valley sides are still high and steep. This combination of characteristics belonging to differtnt stages of erosion is a consequence of the peculiar history of the valley. The great discrepancy in age between the middle Illinois $V^{\top}$ alley and its tributaries is explained by the fact that the former was developed by a powerful river fed by the ice sheet and the temporary lakes in its upper valley (p. 46), and by Lake Chicago, while the latter were formed by very small streams, most of them intermittent.

North central Illinois, taken as a whole, is in a youth ful stage of development. Limited areas bordering the middle Illinois Valley are so dissected by small valleys as to be nearly all slope, and are therefore 


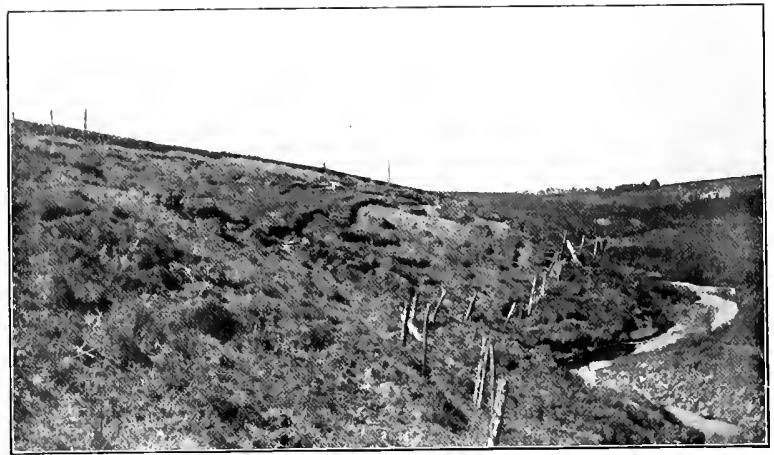

A. The widening of a valley by slumping.

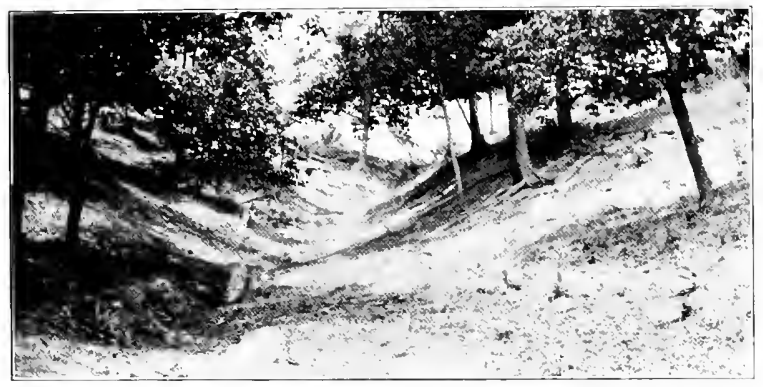

B. Creep on a ravine side hown by leaning trees. 

mature. Sut outside Illinois Valley and the adjacent ravine land, the work of reducing to base-level the surface left by the ice has been scarcely begun.

Influcnce of Illinois River upon configuration of small valleys.IVe have seen that the small valleys cannot be eroded below the level of Illinois Valles, and in connection with certain valleys in the Illinoian drift that deposition by the main river compels deposition by its tributaries. Some of the larger tributary valleys appear to have developed with reference to Illinois Valley when the ice sheet still lingered in the northern part of the area. Later when the Outlet river lowered the main valley, the tributaries were able also to degrade their channels actively. The effect was of course felt first at the mouth of the tributaries, and the new gradient established there extended itself upstream by headward erosion. When this extension was only partly accomplished, the lake ceased to discharge to the southwest, and the Illinois began to aggrade its valley. This of course forced the tributaries to deposit near their moutlis, and as noted under the following heading, deposition is still in progress there. The result of these changes is that many of the larger tributary valleys have steeper gradients in their lower than in their upper courses. This is especially well shown on the Metamora Quadrangle, which extends east of the river far enough to include the heals of a number of large ravines.

Fig. 32. Profile of Dry Run creek, east of Chillicothe.

Figure 32 shows a profile of the bottom of Dry Run Creek east of Chillicothe; the gentle slope of the upper valley is in sharp contrast with the steeper slope of the middle and lower valley. In contrast with this, valley bottoms normally become increasingly steep headward.

Building of alluzial fans.-The condition of the Illinois also compelled its tributaries to build alluvial fans. The alluvial fans of the middle Illinois Valley were described in Chapter I as among its more striking and peculiar features, and their influence upon the position and width of the river discussed. They occur both upon the flood-plain and the terraces of the Illinois at the mouths of practically all the tributary valleys. Their size corresponds ronghly with that of the valleys which they front, and varies from that shown in Plate I, A, and Plate XIII, A, to hundreds of acres. The building of alluvial fans began along the Illinois flood-plain 11pon the loss of the overflow from the Great Lakes. The Outlet river covered the present flood-plain and carried away all the material brought down by the tributaries: the Illinois occupied but a fraction of the old channel, and began at once to deposit. The velocity and hence the transporting power of a tributary was promptly checked when it left the relatively high gradient of its own valley (developed in response to the erosion of the Outlet river) to enter the flat floor of Illinois Valley. The resulting deposit choked the channel of the 
tributary, and some of the water spread to right and left of the obstruction. The process being repeated many times, and the stream meanwhile extending the deposits in the direction of its flow, they acquired more or less of the "fan" shape, which is characteristic of such deposits and which suggested their name. Many of the larger fans are characterized in their onter portions by water channels which give off branches that in turn repeatedly divide. The explanation of these branching channels (distributaries) is involved in what has alrealy been sairl. Deposition in a given chamel reduces its capacity until some of the water breaks over the side and follows an independent course to the margin of the fan: the new channel hecoming cloked, gives off other distributaries. and so the process is repeated. The spreading of the water flowing over the fan becones in itself an important cause of deposition, because it increases the friction of flow, and therefore decreases the velocity. Deposition is also cansed by the fact that frequently much or all of the water sinks into the porous material of the fan. Thus the growth of the fans is due to (I) decrease in gradient, (2) increase in friction of flow, and (3) decrease in volume.

The distribution of the material in the alluvial fans is worthy of note. The coarsest material is clropped at the apex where the stream is first checked and the ceposit marte at any given time becomes progressively finer toward the margin. This does not mean that a vertical section throtugh an allurial fan, all parts of which are at the same distance from the apex, would show material of the same degree of coarseness. On the other hand, the material would be likely to change frequently both horizontally and vertically, for the volume (and so the transporting power) of different distributaries would vary at the same time, and of any given distributary at different times. Such variations near the tops of various fans may be seen in the walls of the chamels which cross them. Great variations are shown also in a series of borings made by the Peoria Water Works Company in the fan of Ten-Mile Creek.

The angles of slope of fans depend upon how suddenly and how much the velucity of the depositing waters was reduced, and upon the kind and amount of material they carried. A sudden and great reduction in the velocity of a stream heavily loaded with coarse material, gives a relatively steep slope: the opposite combination a gentle one. In general, the smaller intermittent streams have built relatively steep fans, while those of larger streams, such as Farm Creek (fig. 13 and P1. II), have low slopes. Like other depositional slopes (see fig. 12 and $\mathrm{Pl}$. IV $\mathrm{P}$ ), the profile of a fan along any radius is a curve concave upwards. This may be readily seen in the smaller fans (PI. I, A). The fans located upon the Illinois flood-plain would be even more conspicuous were it not for the up-huilding of the flat which surrounds them. ${ }^{1}$

Changes in stream conrses. - There are a few examples within the area of sections of valleys that have been deserted by the streans which

'Some idea of the rate at which Farm Creek ha extented its deposits ma he gained from the following: "This lake (Lake perrin) wa twenty-tise vears ago much wider at the lower end, but since that time the little Farm Creek has formed alwit a hnnired acres nf alluvium just opposite the middle part of the city." (llistory of Perria County (18s0), p. 293). 


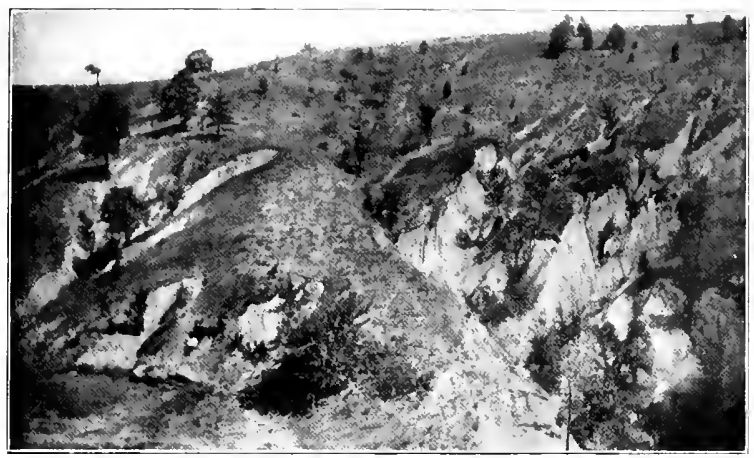

A. View illustriting truggle for existence among gullies.

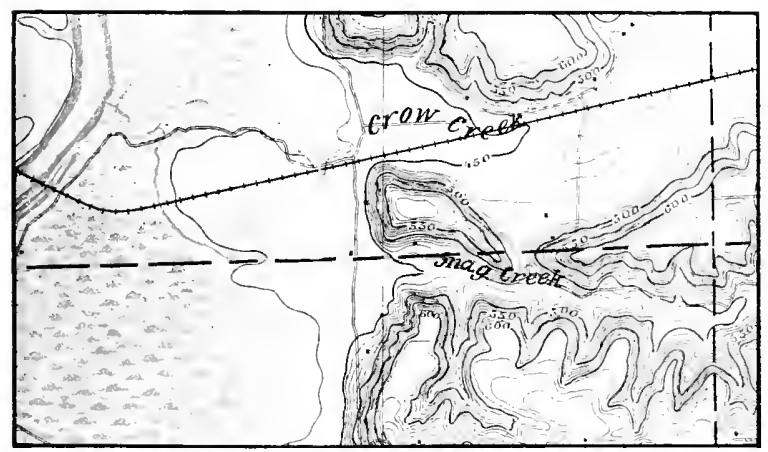
13. Map showing stream Iiracy eat of Chillicothe. (Portion of Metamora topugraphic map,
U. S. Geol. Surv.) 

once occupied them. One is shown in Plate $\mathrm{XV}^{t^{*}}$. B. The depression between the valleys of Crow Creek and Snag Creek, through which the wagon road passes, was clearly formed by running water. That Snag Creek formerly flowed through it into Crow Creek, and not Crow Creek to join Snag Creek, is strongly suggested by the trend of the bluffs on either side of the depression. A small tributary of the Illinois, occupying what is now the lower portion of the valley of Snag Creek, appears to have worked loack by headward erosion until it reached Snag Creek, which it diverted to its present course. Similar changes in drainage have occurred on a vastly larger scale in various parts of the Appalachian mountain region. A stream which accomplishes such a diversion is known as a pirate, and the process as stream piracy.

A change has taken place in the course of Big Bureau Creek, 2 miles northwest of Princeton. A few other drainage changes have occurred elsewhere in the area.

\section{Other I'ost-Gl.ichal Chincies.}

In addition to the matters noted above, various less conspicuous, but not unimportant changes have been in progress. The wind has shifted much fine material about, of which no record is preserved in surface features; an unknown, but doubtless large amount has been carried entirely outside the area, but on the other hand, a large quantity has also been importerl. Rains have washed vast quantities of earth from higher to lower levels; their efficiency is shown, for example, in the reduction of certain sections of the Illinois bluffs (Pl. IV). The oxygen of the atmosphere has entered into combination with the iron of the upper till, producing its characteristic redclish-yellow color. Ground waters have generally removed in solution the soluble constituents of the till in the surface zone; locally they have deposited material from solution, cementing originally loose drift into compact rock. Earthworms have brought large quantities of fine material up to the surface, making important contributions to the soil. On the flood-plain of Illinois River and on the flat upland prairie where drainage is poor, partially decayed vegetation has been mixed in large quantity with the surface material to form rich black soils: on the hilly land just back from the lllinois bluffs it is removed by erosion, and the yellow soil is less fertile. Locally, as indicated on page 19, deposits of peat are being made on the flood-plain. 


\section{CHAPTER V.}

THE SETTLEMENT AND DEVELOPMENT OF THE REGION.

\section{INTRODUCTION.}

Any discussion of the geographic conditions that have influenced the development of the middle Illinois Valley must consider many events and places outside the area itself. Thus, for example, steam navigation upon the Great Lakes, the lumber industry of Michigan and Wisconsin, and the Illinois and Michigan Canal vitally affected the region. This chapter, therefore, is less local in its discussion than the preceding ones.

One of the most important geographic factors in the history of Illinois is its location between the Great Lakes and the Mississippi. Throughout the history of the State, Illinois Valley has formed the greatest natural highway between the two. It was followed by the first white men who crossed the State; it became an important highway of the fur trader: and it guided toward the north a great stream of Southern settlers, which met and mingled in the middle valley with a wave of immigration from the East that had followed the valley south from the vicinity of Lake Michigan. Today the counties bordering the Illinois and its continuation, the Jllinois-Michigan Canal, contain over one-half (51 per cent) of the population of the State.

\section{Southern Pioneers in the Region.}

Illinois is 385 miles in length, extending from the latitude of Lynn, Massachusetts, to that of Newport News, Virginia. Since American expansion has been chiefly westward, along such highways as the Great Lakes and the Ohio, the State drew its early population from widely separated areas. The southern part was occupied by people largely from the South and Southwest, while the northern portion was settled by immigrants from the Middle Atlantic States and New England.

The accompanying maps, figures 33 and 34 , show the advance of southern settlement toward Illinois Valley. In 1820 (fig. 33) population was confined to the southern portion of the State, and chiefiy to the vicinity of Wabash, Ohio, and Mississippi rivers, and certain 


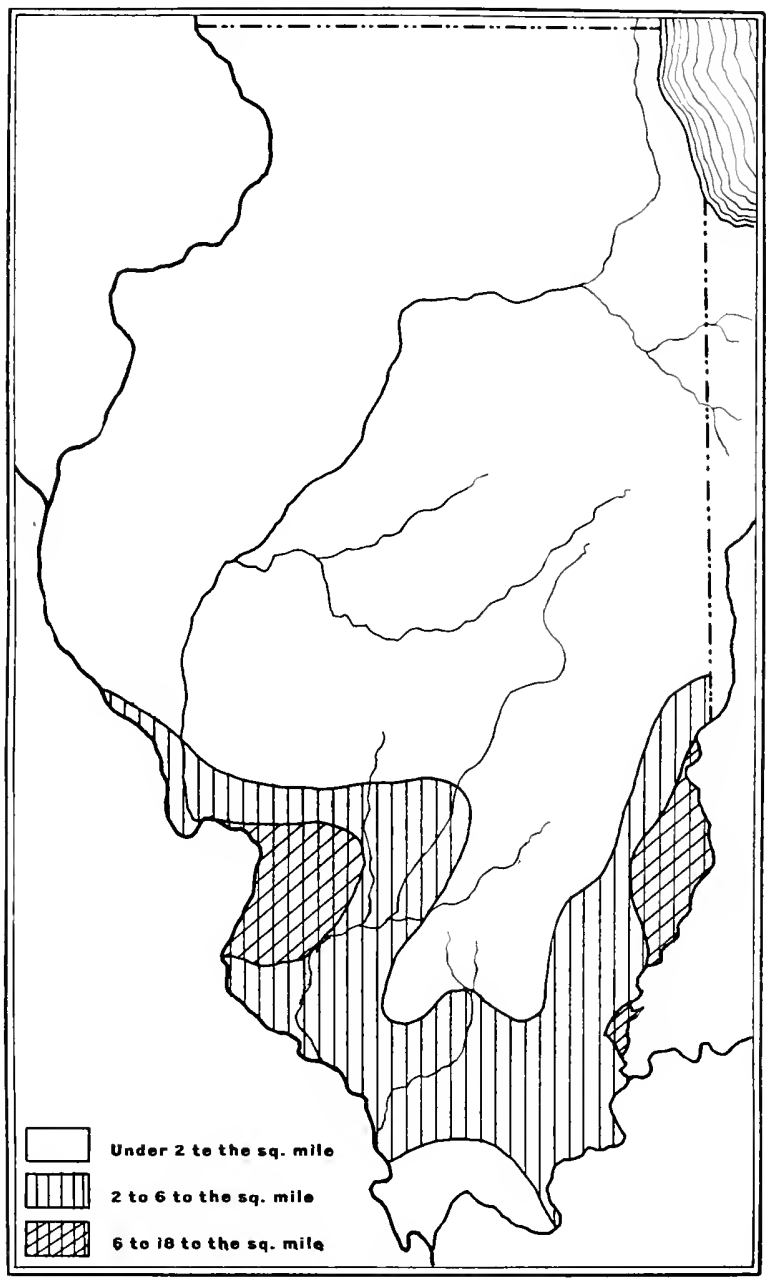

FIo. 33. Map showing distribution and density of population in Illinois in $\mathbf{1 8 2 0 .}$ 
of their larger tributaries. Not a man in the constitutional convention that met at Kaskaskia in 1818 came from any portion of the State north of Madison and Crawford counties. ${ }^{1}$ In 1819 a farm in southwestern Logan County was thought to be the most northerly in the State. ${ }^{2}$ These people had cone from the Piedmont Plateau, and especially from Kentucky and Tennessee. The areas of richer soil in the last mentioned states had become overcrowded to the typical frontiersman, who sought cheaper land and freer conditions farther west. A portion of this overflow was insured to Illinois by ( 1 ) its extension southward well beyond the northernmost latitude of Kentucky, (2) its nearness, and (3) the various navigable rivers which, leading from the older settlements, focused upon its soutiern border.

During the next few years, settlement spread northward into the Sangamon region. In 1823, Springfield was a frontier village containing a dozen $\log$ cabins; the site of Peoria was occupied by a few families, and that of Chicago by a military and trading post. ${ }^{3}$ The rest of northern Illinois was entirely unoccupied. In the latter part of the twenties the Sangamon country filled rapidly, one hundred wagons in a single train being frequently seen on their way there. ${ }^{*}$ A new impetus was given to the novement by the establishment of steam navigation on Illinois River in 1828. By 1830 (fig. 34) the Sangamon district was overflowing into Illinois Vallev, which contained a few settlers well beyond Peoria. Tazewell ${ }^{5}$ and Woodford $^{6}$ counties had received their first settlers in 1823, Marshall County in 1827, and Bureau County in $1828 .^{8}$

The southern pioneers who settled Illinois were hunters rather than farmers. They were thoroughly familiar through generations of experience with the conditions and problems of forest life, but at their coming knew nothing of conditions on the prairies. Their advance northward was therefore in general limited to the forest area (fig. $35^{9}$ ) They had, however, followed the wooded banks of the Illinois well into the prairie region. Small clearings in the timber were tilled in an irregular and unscientific manner, and the hunter pioneer was being slowly transformed into the farmer. It appeared likely that the entire Illinois Valley and. when the problem of handling the prairies should finally be solved, all the northern portion of the State would be settled by southerners, and dominated by southern institutions and ideals. Fear of such a possibility, and of its possible political consequences had led Congress to give Illinois its present northern boundary line when it

1 Ballance: Hixtory of Peoria, n. 50.

2 Ferdinnd Emit: Publ. No. 8 of the Hist. Lib. of Ill, p. 161

a tharh: Annals of the West, T. 993.

4 Pooley: Universits of Wisconsin Bulletin, No, 220, p. 89.

5 Batenian and Selhy: Historical Encsclonedia of lllinois, p. 418.

${ }^{8}$ History of Woorford County, r. 227.

7 Bateman and Selby: Historical Encyctonedia of Illinois, p. 3.53.

8 Ibid., p. 67 ; Matson: Reminiscences of Bureau County, p. 247.

- This man, published by Cerhard in his "lllinois as it is" (1857), is about the only one which shows the original listribution of woodtand and prairie with any approach to accuracy. Even it, however, is faulty, at least locally, in details. Some attempt, based on local diseussions, has been mare to correct it in the six counties of the report. Elsewhere it remains unchanged. A statement of the ratio of wondland to total nrea throughout the State in 1880 may be found in Porter: The West in 18s0, pp. 162-163. 


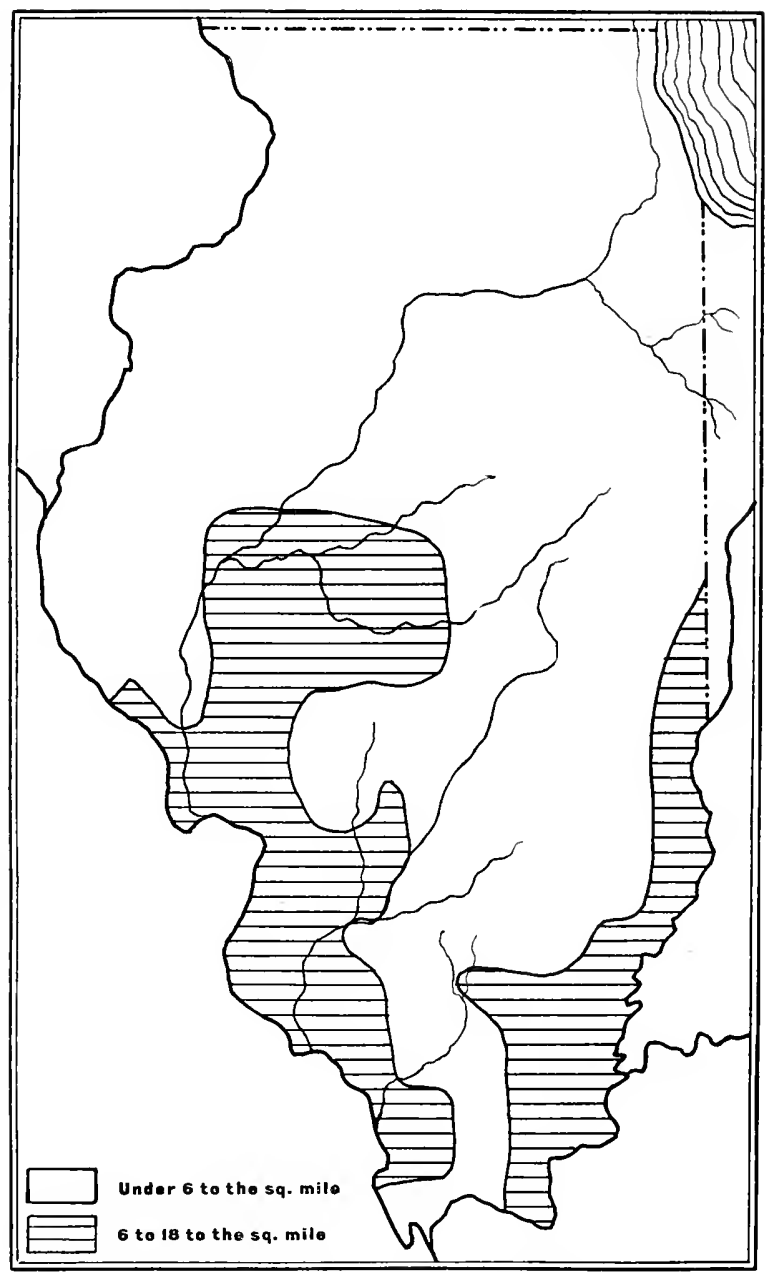

Fro. 34. Map showing distribution and density of population in Illinois in 1830 . 
was admitted as a State in 1818, in place of the line originally intended, extending due west from the sonthern bend of Lake Michigan. It was hoped that the 50 miles of frontage on Lake Nichigan would give (as it did) the northern part of Illinois many settlers from the northeastern states, and close commercial and political ties with that section. ${ }^{1}$ In 1832 the southern alvance along Illinois Valley was checked, and, save at Peoria, the settlers were driven sonth and east of the river by Black Hawk's war. Before the southern frontier had recovered from this blow, a great northern stream of immigration from New York and New England had swept into the moccupied portions of the valley, occupying first the woolland and later the prairie.

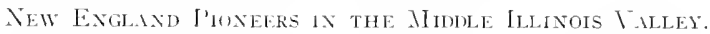

Canses of emigration from la England-For two centuries New England was dominated by the ocean, its prosperity dependent chiefly on shipbuilding, fishing, and the carrying trate. This section, therefore, took comparatively little part in the westward movenent until long after the land-hungry, agricultural sonth. In the decade 1820 to 1830, however, an expansion started up actively from New England that was destined to become a movement of great proportions later. Many causes contributed to it." Shipping declined. Agriculture was extensively replaced by sheep and cattle raising in the back-country uplands, and many small farmers found it adrantageous to sell their land to stock growers and go west. The lowlands were occupied, and wheat conld not be grown with profit on the stony, infertile hillsides, particnlarly in the face of western competition. Immigrants displaced native workers in many mils. The financial crisis of 1837 combined with crop failures to increase the economic vlistress. On the other hand, conditions upon the western frontier were very attractive to the struggling New England farmer. In 1820 government land was reduced to \$1.25 an acre in hlocks as small as 80 acres. Much larger crops could be grown with much less labor. Furthermore, the expense and time involved in reaching the IVest were greatly reduced by the opening of the Erie Canal in 1825, and the development of steam navigation upon the western lakes in the thirties. These improvements also meant cheap transportation of western grain to eastern markets, once it had reached a lake port. The first emigrants sent glowing descriptions of the west ern lands to friends and relatives in the East: discontent and restlessness became general, and tens of thonsands turned their faces to the west to start life anew. Large contributions to the western population were also made by the states farther south, where econonic conditions were also unsatisfactory.

Principal routes to the middle Illinois Talley--Eefore the opening of the Erie Canal, the journey from New England to the WVest Was slow, difficult, and expensive. Emigrants from western New England

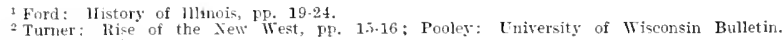
No. 220 . pp. $44-53$.
} 


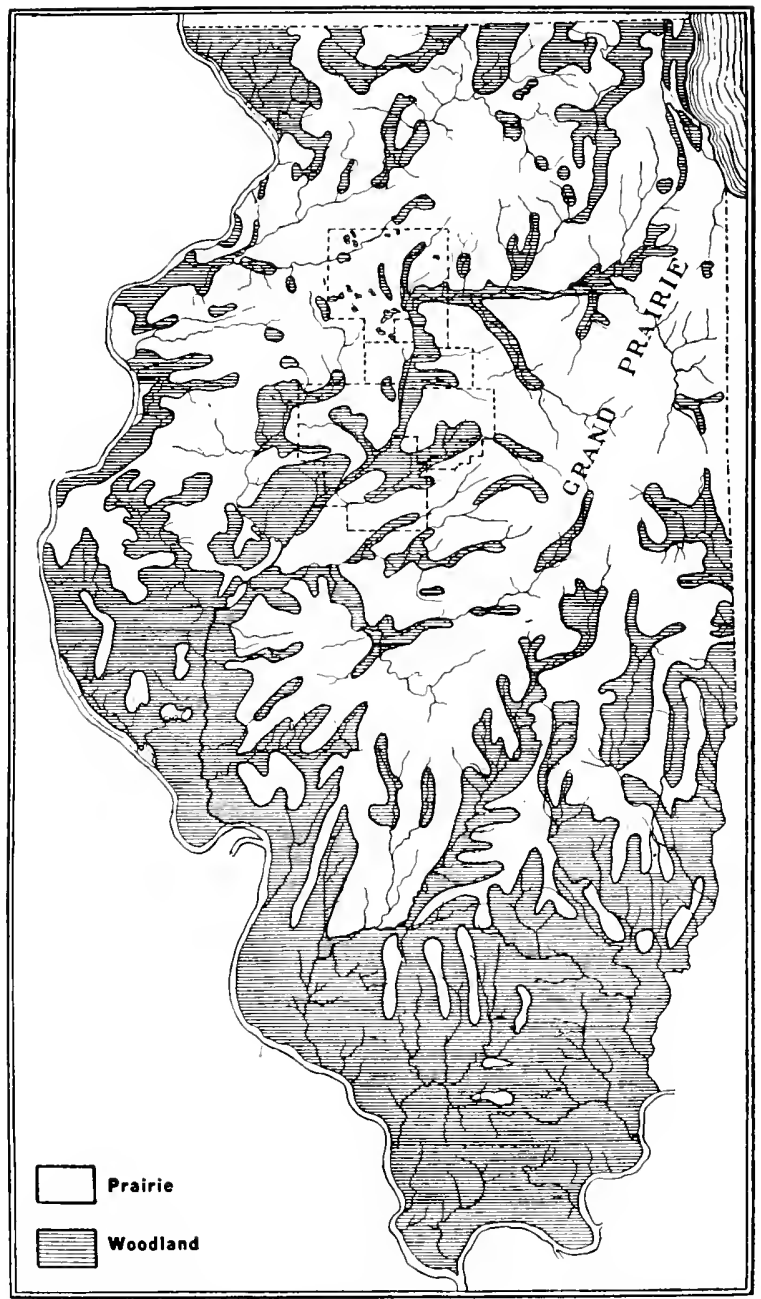

FIG. 35. Map showing distribution of prairie and woodland in Illinois, (Modified from Gerhard.) 
coulil use the Mohawk and Genesee Turmpike to Lake Erie, or the Catskill Turnpike to the upper Alleghem. ${ }^{1}$ Those leaving eastern New England usually went by sea to Philadelphia or Baltimore and thence by stage over the Allegheny Mountains to Ohio River. It required 27 lays for a party from [ioston to come in 1831 to the lower Illinois Valley by way of Pittsburg and the Ohio, Mississippi, and Illinois rivers. The household goods, sent from Boston by sea to New Orleans and up Mississippi River, arrived much later. ${ }^{2}$ In 1838, the passenger fare from New York to Peoria by way of Philadelphia, Pittsburg, and St. Lonis, involving railroad, canal, and river travel, was $\$ 40.00$ to $\$+5.000^{3}$

The Erie Canal promptly became the most important route to Lake Erie in 1825. There were still, however, few vessels upon the lower lakes and none regularly upon the upper, so that various courses were fullowed from Lake Erie to Illinois Valley. Some went from Buffalo by boat to Erie, by stage from Erie to Beaver, and thence by steamboat to St. Louis and Illinois River. In 1831, the fare from New York City to St. Louis by this route was $\$ 57.62 .^{*}$ Others left the Lake Erie boats at Ashtabula or Cleveland and went south to Ohio River. Occasionally travelers left Ohio River at Cincinnati and journeyed by stage to St. Louis. ${ }^{5}$ The line of Ohio, Mississippi, and Illinois rivers was often used by people intending to settle as far north as Bureau County $y^{6}$ : in 18.30 such settlers found steamboat service available to Peoria, but the remainder of the trip was by land, or canoe and keel boat. Some of the Burean County settlers using this route sent their goods by ship to New Orleans. The difficult part of the trip was considerably shortened when steamboats ran west regularly to Maumee Bay and Detroit. From the former point emigrants sometimes went up Manmee River in keel boats, hauled their goods across the 12 or 15 mile portage to the IVabash, and floated down the latter stream to the vicinity of Terre Haute, from which ponit they went west by wagon into Illinois." Enigrants are known to have made their way from Detroit to Bureau County on foot. ${ }^{8}$ The delays and difficulties encountered in reaching Illinois Valley as late as 1831 are strikingly illustrated by the experiences of the founders of Princeton. This place, like many of the early towns in New England, was founded as a colony by a religious society, and not by individuals as such. The Hampshire Colony was organized at Northampton, Massachusetts, in March, 1831. In May the members of the colony met at Albany for the trip west. They went by canal boat to Fuffalo, and from there by steamer to Detroit. Unable to secure passage on a sailing vessel to Chicago, they hired

Turner: Rise of the New West, 1p, so-s2.

2 Willard: Transactions Illinois Historical Society, 1906, p. 74.

Jones: Illinois and the West, p. 2.5.

+ Illinois Monthly Mngazine, V, 2, D, 53

- Flint: Railroads of the United States, p. 257. p. 253 .

Bradsby: History of Bureau County, pp. 86, 129; Matson: Reminiscences of Bureau County,

7 Conkey: Transactions I11inois Historical Society, 1906, pp. 214-218.

Mlatson: Reminiseences of Bureau County, p. 252. 
teams and went overland to Mottsville, Michigan, on St. Joseph River. From this point they proceeded down stream in canoes 65 miles to the great bend, where a five mile portage led to the Kankakee, down which they floated into the Illinois. ${ }^{1}$

Navigation was late in developing upon Lake Mlichigan, and not until $183+$ could emigrants count with certainty upon transportation to Chicago. In 1831 only three sailing vessels came to Chicago. ${ }^{2}$ The first steamboat arrived in $1832 .^{3}$ From then on, the number of arriving vessels increased rapidly; there were $t$ in $1833 ; 176$ in $1834 ; 250$ in 1835 and 456 in $1836 .{ }^{*}$ In 1840 there were 48 steamers on the upper lakes, and in 1841 six of the largest boats were regularly employed in rumning from Buffalo to Chicago. Tiy 1848 there were 400 vessels, including over 64 steamers, navigating the lakes. ${ }^{6}$ With the multiplication and improvement of boats, the length and cost of the trip to Illinois were greatly reduced. ${ }^{\top}$ In 1840 the distance from Chicago to liuffalo had been covered in two days and two nights. ${ }^{\text {Cabin fare on }}$ the better boats from Buffalo to Chicago fell from about $\$ 25.00$ in $1838,{ }^{9}$ to $\$ 6.00$ in $1852 .{ }^{10}$ Steerage fare was considerably less. It was now possible, furthermore, to take household goods, farming implements, and stock into the west easily and cheaply.

Numbers of northern immigrants. - A flood of settlers now poured into Illinois V $\mathrm{T}$ alley and the northern part of the State generally. In 1845 the steamboats alone carried 97,736 passengers from Buffalo to the west, of whom 20,244 were landed at Chicago. ${ }^{11}$ They had been carring nearly as many for several years. Many also went in sailing vessels. Buffalo had shipped to Illinois in 1843 nearly 7 million pounds of merchandise, and over $1^{1 / 4}$ million pounds of furniture. ${ }^{12}$ Chicagn was the gateway to Illinois Valley. From a "little mushroom town"13 in 1833, and a "dirty village of twenty hamlets"14 in 1834, it grew to a poptulation of 4,479 in 1840 , and 28,269 in $1850 .{ }^{15}$ The value of its imports rose 523 per cent in the ten years following 1836 . $^{\text {th }}$ It is not easy to overestimate the importance of steam navigation on the Great Lakes in the settlement of the connties with which this report is especially concerned, and northern lllinois in general. A recent writer has declared that "the great pervading power which influenced the settlement of northern Illinois and built up this portion of the State

1 Matson: Reminiscences of Bureau County, pp. 261-26?

2 Parker: Growth of Illinois and Chicago, p. 14.

Jibach: Amnals of the West, p. 957; Blanchard: The Northwest and Chicago, 0.423.

Niles Weekly Register, V. 51, p. 274 ; Mitchell: Sketches of lllinois, p. 31; Blanchard

The Northwest and Chicago, p, 423 .

Albach: Annals of the West, p. 958

Gall: The West: Its Commerce and Navigation, r. 33.

Ferris: The States and Territories of the Great West, p, 204.

Pooley: University Wisconsin Bulletin, No. 220, p. 75.

- Jones: Illinois and the West, p. 254.

10 Curtise: Western Portraiture, p. 31.

11 Albach. Annals of the West, pp, 959-959.

12 Hall: The West; Its Commerce and Navigation, p. 35.

13 Ferris: The States and Territories of the Great West, p. 212.

14. Jones: Illinois and the West, pp. 236-237.

15 De Bows' Review, V. 17, p. 262.

16 Idem, V. 13, p. 198. 


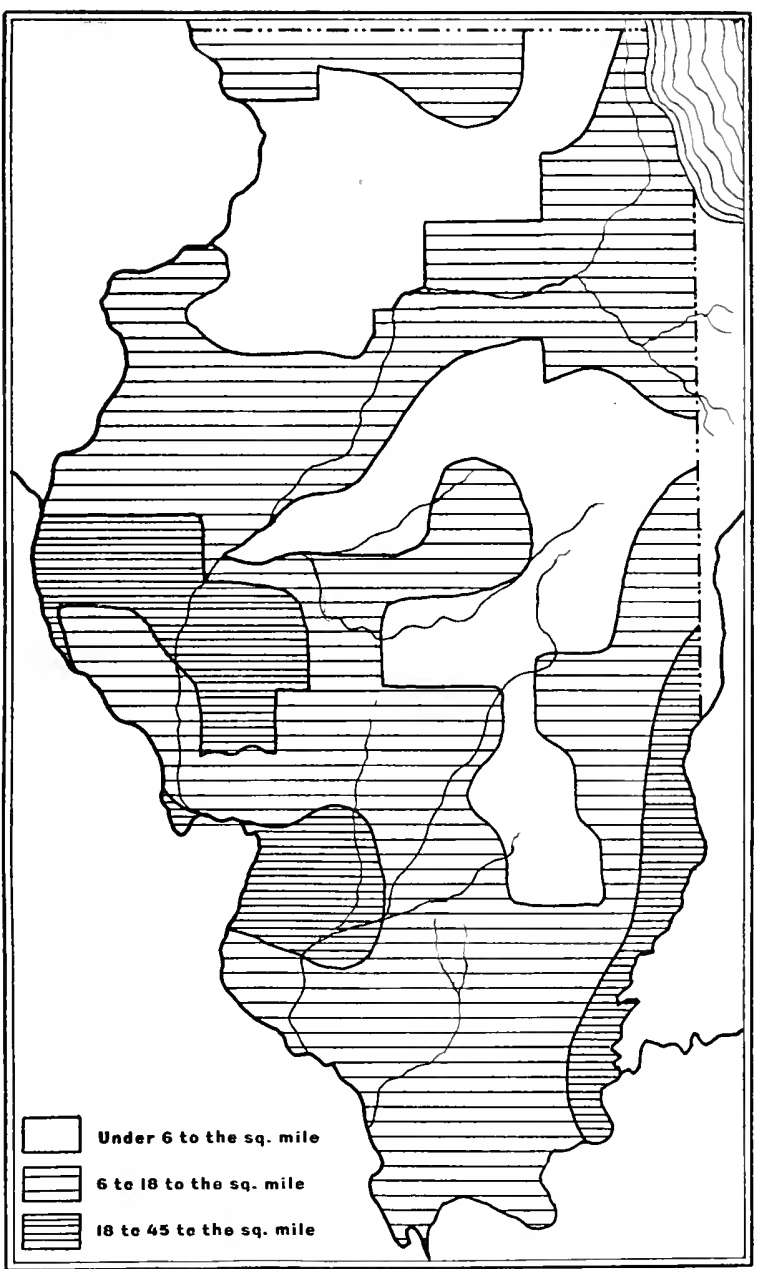

Fig. 36. Map showing distribution and density of population in Illinois in $\mathbf{1 8 4 0 .}$ 


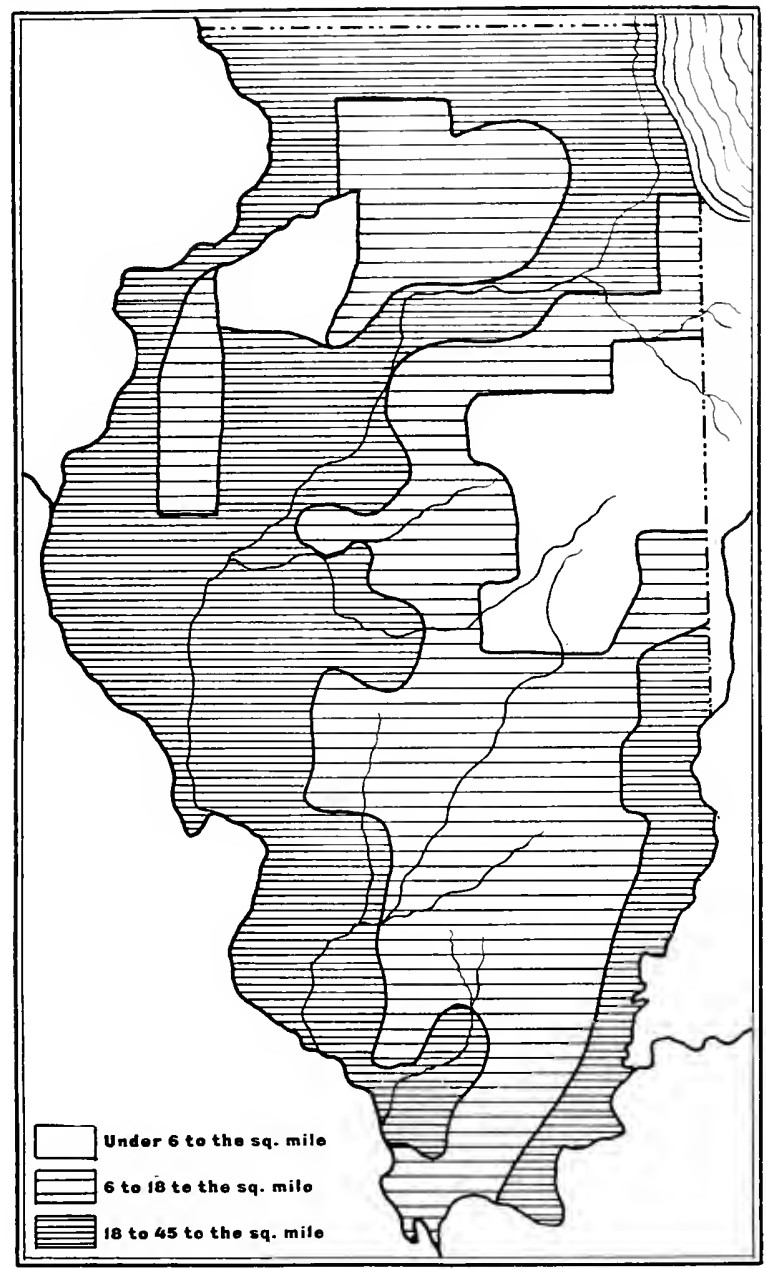

F1G. 37. Map showing distribution and density of population in Illinois in 1850 . 
with astonishing rapidity and which gave the northern character to its population, was the development of steam navigation upon the lakes."

The influence of Illinois Valley upon the distribution of this northern population entering by way of the lakes is shown by figure 36 , which represents the distribution of population in Illinois in $18+0$. The population maps of 1850 and 1860 (figs. 37 and 38 ) are equally instructive in this particular."

\section{Northern l'ionefrs Domixite the Region}

In the middle Illinois Valley connties, from Tazewell and Peoria to Putnam and Inteat, the southern and northern waves of expansion met and mingled. This was rlue to geographic conditions. The southerner, arriving first, had followed the timber bordering the Illinois far into the great prairie area. The northerner, following the Great Lakes, had been guided by the Chicago Ontlet and the upper Illinois Valley to the same region.

In Tazewell County the great majority of the early settlers were from the South. This was less strikingly true in Woulford County. In Marshall County the two elements were more nearly balanced, while in Putman and Bureau the northerners overwhelmingly predominated. A rulle stratification of the two types of settlers resulted from the fact that the timber was confined to the borders of the streans, while the inter-strean areas, save for occasinnal island-like groves, were prairies (fig. 35). Tongues of southern influence extended north along the timber strips, while New Englanders and New Yorkers, npon solving the problem of the smaller prairies, pusherl south between them. Delavan, in southern Tazewell Countr, was an interesting New England prairie colony of this type. Many of the northeastern immigrants settled in towns on coming to Illinois, and contributed to their rapid growth." Thus Peoria, though all save one of the first permanent Imerican settlers were snithemers.' soon took on the characteristics of a New York or New England town. (of the $6+2$ voters in Peoria in 1845, 402 were natives of states north of Ohio and Potomac rivers, and 52 of states south of those vivers; only 2 were born in Illinois, and 2 west of the Mississippi, while 184 were natives of Europe. ${ }^{.}$The character of Illinois Vallev as a great highway of travel and migration is reflected in the fact that these voters represented twenty-one states and ten Furopean countries. Five rears later a writer said of Peoria, "the population of our city, as the western phrase is, is mightily mixed,' from 43 states and kingdoms." ${ }^{3}$ Half the states in the ['nion were representerl in Noodford Countr.'

1 Pooley: University Wisconsin Bulletin. Sn, 2200, I, 9s.

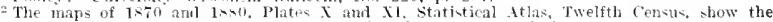
sontinued influence of Illinois Valley upor the distribution of population.

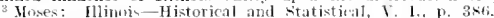

* Peoria was settled in trril, 1s19. by a party of seven imericans from shoul creek, clinton County, Itlinots, of the foumders, two were Kentuckians, two Yirginians, ant one frm New Yurk. Two went overland to Peoria with pack horses, the others in a keel brat up Mississippi and Illinois rivers brown: Recurs and Historimal view of Peoria, p. bl.

sallance: Hintory of Peoria, pp. 2n1-202.

arown: Record and Historical Yow of Peoria, p, 115

7 Ifistory of Woodford Cimuty, p. 224 


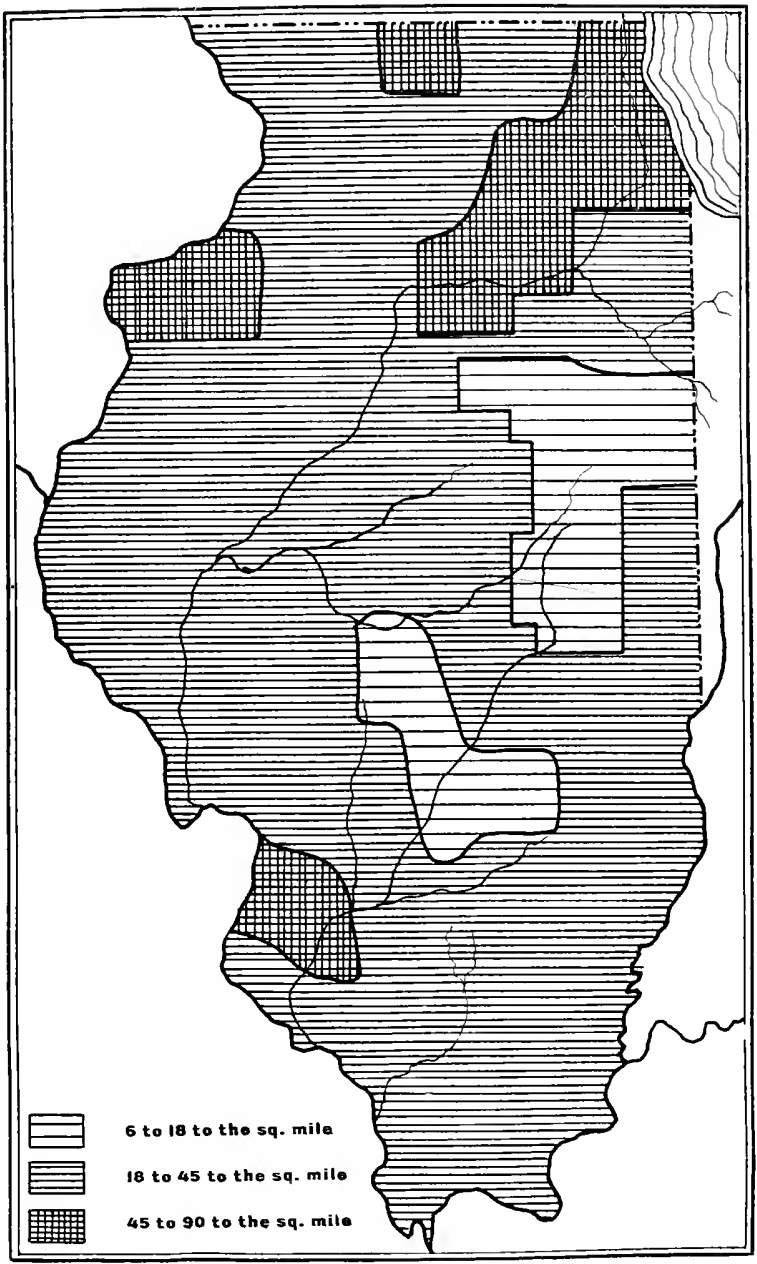

FIG. 38. Map showing distribution and density of population in Illinois in 1860 . 
The struggle between the northern and southern settlers for dominance in the middle Illinois Valley was only a phase of a larger contest involving all middle and northern Illinois. Largely because of the development of navigation tpon the lakes, numbers were on the side of the northerners. The New Englanders and New Yorkers, furthermore, were, as a rule, possessed of greater means, and characterized by greater energy, thrift, and ingenuity, traits influced in no small degree through generations by the geographic conditions of New England. ${ }^{1}$ They accordingly presently impressed the stamp of northern institutions and ideals upon the debatable territory.

\section{Distribution of E.arly Population.}

The census maps (figs, 33, 34, 36, 37, 38) give only a general idea of the distribution of population, since ther are based on the county as a unit. Attention is now directed to the several factors which determined the immediate distribution of the early settlers.

Natigable streams.-One of the greatest problems facing the pioneer was the transportation of his produce to a market. For years there were few roads and these unimproved, so that the black soils of the upland prairie became a well nigh impassable sea of mud when saturated. ${ }^{2}$ This was invariably the case in spring, when travelers might confidently "expect to be obliged to warle through mire and wateranl:le deep, knee deep, and peradventure deeper than that." Illinois River was the only connection with the outside world until the appearance of the railroad, unless the journey were made by wagon to Chicago. In general, therefore, the earlier settlers located near the Illinois or one of its navigable tributaries. A number of its tributaries, now totally unfit for navigation, could be used by flat boats and canoes before the more or less complete removal of the timber which bordered them. This was true, for example, of Crow Creek, opposite Chillicothe. ${ }^{*}$

Bottom lands and lerraces. - While it was highly desirable to be within easy hauling distance of Illinois River, settlers commonly avoided its heavily wooded and unhealthful flood-plain. Fever and ague were especially to be dreaded on the lower portions of the flood-plain near the bluffs, ${ }^{5}$ and settlers who chose the bottom lands were advised to build their homes on the lighest part of the natural levee, at the edge of the stream," Here wondcutters occasionally established themselves but

It was feared by some that the New Englander would lose these characteristics in the llinois Valley. A correspondent of the New York Oherver wrote, in 1540, that "the two greatest objections to the west, in my jurdement. are, that the land is too cheap and too productive. Taking human nature as it is, however industrims and virtuous emigrants from the scanty and rugged soils of New Enginul ma he, they mut in general, without a miracle to prevent it, degenerate when planted down in the fat valleys af the suju, the Walma, or the lllinois. It is a law of our lapsed natures, not to work if we can help it." Western Farmer, V. I., p. 147.

The character of the settlirs ws, inleet, somewhat mollitied by the new environment. "Even the quiet, conserwative men from the East hecme rough, indenendent and simple in habits, careless of dress, frank in speech, frjendly anl generous to all whom they conld trust." Pooley' University Wisconsin Bulletin, Xo. 290, p. 269.

"Bradsby: History of Burean County, pp. 401-402.

3 Ilinois ifonthly Jagazine. I. 2, p. 49.

- Beck: Gazetteer of llinois and Missonri, 3. 103.

S Idem, p. 18; and l)ana: (ieographical Shetches on the Western Country, pp. 141-142.

- Peck: Guide for Emigrants, P. 179. 
rarely, if ever, escaped the flood-plain diseases. ${ }^{1}$ The bottoms of tributary valleys were often more desirable. Thus the combined invitation of fertile soil and navigable waterway led to the occupation of the lower Crow Creek Valley as early as 1830 , and a considerable settlement soon developed. ${ }^{2}$

The terraces of the Illinois were very much more desirable than the flood plain, and were occupied early. For several years the population of Peoria County was largely confined to the Peoria and Chillicothe terraces. ${ }^{3}$ The Henry terrace was one of the first parts of Marshall County settled, ${ }^{*}$

II oodland and prairie.-The prairies of northern Illinois aroused the wonder of all early travelers. They were attributed to fires; to hurricanes which had blown down the timber, leaving it to be readily consumed by fire when dry; to the former presence of lakes; and to other causes. ${ }^{5}$ The upland prairies are now generally thought to have been due to the undrained condition of the flattish inter-stream areas, which practically prevented the growth of the species of trees adapted to the latitude. Occasional protracted droughts and fires, furthermore, doubtless served to kill any young trees that had succeeded in establishing themselves. Summer droughts were especially effective in killing seedlings on the sandy terraces of Illinois Valley, where they were probably a chief cause of the general absence of trees. Quite as much as any other factor, the distribution of woodland and prairie affected the settlement and early life of the region under discussion.

The prairies were generally shunned by the first comers for several reasons: (I) Absence of trees was thought to mean that they were infertile. (2) Timber was imperatively needed for buildings, fences, and fuel. ${ }^{6}$ (3) They did not afford running water for stock or mills. while the lack of fuel left steam mills out of the question. ${ }^{7}$ (4) There was no protection from the bitter winds of winter, which, above all else, made that season disagreeable. ${ }^{8}$ Men and cattle had even been known to perish in storms on the open prairie. ${ }^{9}$ (5) To the farmer, the prairies with their tough sod and matted roots constituted a new and altogether unknown problem. ${ }^{10}$ Men were for a time helpless before

IFlagg: The Far West, V. I., p. 98; Jones: 1llinois and the West, p. 171.

2 Ford: History of Putnan and Marsball Counties, p. 130.

${ }^{3}$ History of Peoria County, p. 285.

4 Ford: History of Putnani and Marshali Counties, pp. 136-137.

5. Peck: Guide for Emigrants, pp. 111-116.

6 The great demand for timber in central and northers 11 inois was amusingly illustrated in the middle thirties in the lower part of the peninsula between lllinois and Mlississippi rivers. This was a hilly, wooded district (FIG. 35) where lumbering was an inportant early industry. Lumbermen stole timber in large quantities from the lands of non-resident owners, to whom it had been given for services in the bar of 1812. The latter brought suits for damage, but the witnesses and jurors being all on the other side, nothing was accomplished. Then ininisters of tlue gospel were sent out to preach the sin of stealing timber. Each preacher had a regular circuit, and was paid by the sermon. It is sail, however, that the non-resident owners succeeded no better in protecting their timber by the gospel than they had by law. Ford: History of Illinois, p. 171 .

7 History of Woodford County, p. 386.

${ }^{8}$ Peyton: Statistical Yiew of Illinois, p. 11.

- Hoffman: A Vinter in the Far West, V. 2, p. 55.

10 Albach: Annals of the West. p. 993; Western Monthly Magazine, V. 5, p. 341; Matson: Reminiscences of Bureau County, pp. 397-398. 
this problem, and the prairies were generally regarded as "uninhabitable for an age." As late as 1836 the few who thought the prairies capable of occupation were regarded as crazy visionaries. ${ }^{1}$

The combined influence of streams and timber withheld large portions of the middle Illinois Valley counties from settlement for many years, for prairie land predominated in Tazewell County, about half of Peoria county was treeless." and nine-tenths of Pureau county was originally without timber." Figure 35 shows prairie land somewhat in excess of woodland in Putuam and Marshall counties, and greatly so in Woodford County.

A good idea of the general effect of the distribution of timber and prairie upon settlement referred to in the case of the southern pioneer= on page 60, may be obtained by comparing figure 35 with figures 34. 36. and 37. The influence of the Grand Prairie and of the great prairies north of Illinois River is especially well shown on the population map for 1840 , and is clearly evident ten years later. It will, of course, be understond that the settled area had been occupied not simply hecause of the timber. but also because of the streams, which, as al. ready pointed out. constituted at first the only, and until after 1850 , the best highways leading to the rest of the country.

Figure 39 shows the original distribution of woodland and prairie in Burean Counts. In 1831 the settlers ( 16 families) were almost all in the edge of the Big Bureau timber. Five years later the western tier of townships was without a single inhabitant, and the tier next east had only five famlies. all in Concord Township. There was no one living in Wheatiand or IVestfield townships, while Walnut. Ohio, and Milo townships each contained one family. ${ }^{B}$ The settlers still reared their log cabins almost entirely in the edge of the timber by the side of springs; large prairie tracts hail not even been surveved. Indeed, Ohio and Walnut townships, although among the most fertile in the countr, were mostly vacant until after $18500^{7}$ The same distribution of early population olitained in the other counties of the middle valley and throughout the northern part of the State. ${ }^{\mathrm{s}}$ The Lnion Grove area near Florid, in Putnam County, was settled in 1829, and increased in poptrlation faster than any other part of the county. ${ }^{9}$ Most of the earliest settlers to the east of Lacon occupied the edge of the woods of Sandy and Crow creeks and the Illinois bluffs, in preference to Round Prairie which las between. ${ }^{10}$ Walnut Grove and the timbered portions of Spring Bay Township, in Woodford County, were settled long be-

In 1536 Alby smith, living near Princeton, became a candidate for the legislature. He hat made a farm on the firairie. althongh lomitions in the erlge of the timher were still available, and hat expremed the opinim that nlt mately all the prairies would he cultivated and crossed by railroals. The penple of the district derifled that a man holding such wild. visionary ideas was not fit to remresent then. Ile wh arrordingly dropped, and Thos. Atwater of llennepin elected. Ilatson: Reminiscences, 13. 39:t.

2llinois in 1.3i. p. 10t; ; Peck: diuite fur Enigrants, p. 30 ?

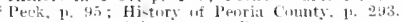

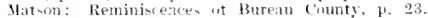

1.lem, n. Dfis.

Brankby: 11 istory of Burkat f'omuts. 1. 171 P. 179.

F Matson: lieminiscences of Bureat Connty, p. 391; Bradsby: Hlistory of Bureau County,

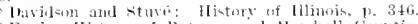

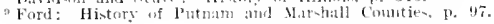

if Idem, p. 12T. 
fore any one ventured out upon the prairie. ${ }^{3}$ A partial exception to the control of the timber appears in the case of the Illinois terraces. As indicated above (p. 77 ) these were settled early, and yet all appear to have been prairies. ${ }^{2}$ Timber could be obtained easily, however, from the adjacent Hood-plain or bluffs, and the other advantage of the ter-

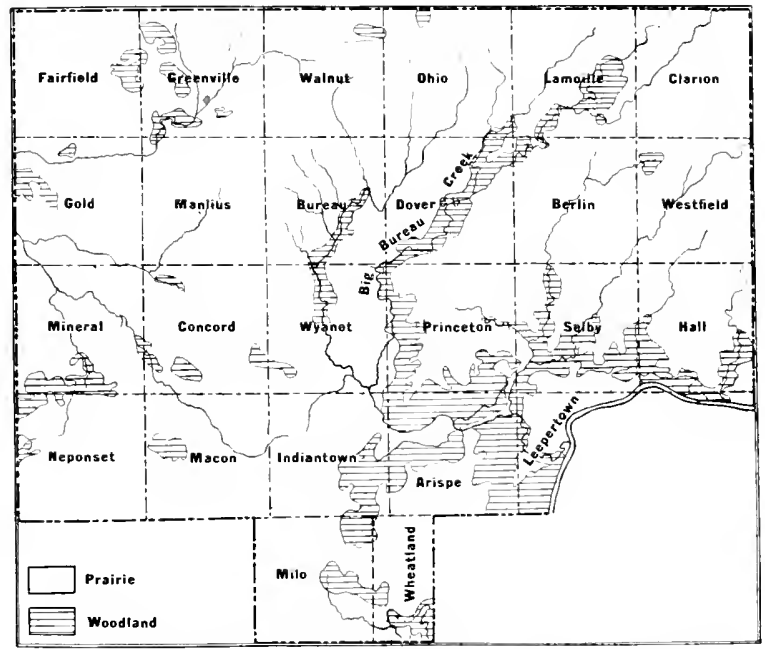

FIG. 39. Map showing original distribution of womlland ani prairie in Bureau County. (Taxpayers and Yoters of Bureau Cumty.)

races were marked. It is interesting to note that settlers were advised to build their homes on the south or southwest edge of the timber, because the summer winds were prevailingly from the southwest and west, while the timber afforded protection against the cold north winds of winter. ${ }^{3}$

\section{The Coxouest of tile Small Prairies}

With the growth of population all the woodland was presently occupied, and new comers were crowded out upon the prairie. From the first, the enterprising New England farmer had used the timber as a base for the conquest of the prairie. He commonly built his cabin in the margin of the timber near a spring and enclosed some of the ad-

${ }^{1}$ Ilistory of Woodiford County, p. 224.

${ }^{2}$ History of Peoria County, p. 285; Ford: llistury of Putnam and lar-hall Counties, pp. 136-137; Ellsworth: Records of the olden Tine, p. 136.

5 Peck: Guide for Emigrants, p. 194. 
joining prairie land. This gave a supply of logs for building and fuel, allowed stock to take refuge from flies or storms in the woods, and permitted the planting of crops without waiting to clear the land. In consequence of this method of settlement, the small prairies were presently encircled with a belt of farms ${ }^{1}$. Later, another ring was established inside the first, and farther ont on the prairie, and by a continuation of the process the entire prairie was finally occupied. ${ }^{2}$ In the course of this process the pioneer learned how to break the prairie sod, and discovered the great fertility of its black clay loams. It was found easier to haul fuel and rails a few miles, than to clear forest land, and prairie farmers often purchased a small piece of land for timber in the nearest woods. ${ }^{3}$ It was discovered that trees grew readily from seed on the prairie. Locally, coal became a cheap fuel. ${ }^{4}$

In general the smallest prairies having the best water supply, and bordered by the heaviest timber, were first occupied. Hoskins Prairie, near Pureau, ${ }^{5}$ Ox Bow Prairie, east of Henry, ${ }^{6}$ and Round Prairie, east of Lacon, ${ }^{7}$ are notable examples. It is said that "in early days Ox Bow Prairie was as well known as Galena, Chicago. Peoria or any point in the State." The larger prairies, away from the stream courses, remained in general unoccupied until after 1850 , for although the settler had learned how to grow large crops upon them, he could not profitably transport the produce to a distant markct. They were settled rapidly. however, upon the development of railroads in the decade 1850 to 1860 (p. 107).

\section{Conditions of Pioneer Life.}

Early priz'ations.-Isolation subjected the earliest pioneers of the valley to many privations, and reduced their household and personal effects to the absolute necessities of life. The homes were rough log houses (Pl. XVI) with puncheon floors and clapboard doors; often there was not a nail or a particle of iron about them. ${ }^{9}$ Indeed, many built their first cabins of saplings, with roofs of bark and clay chimneys. These homes usually contained no fumiture save that which was hewn out with an axe. Homespun garments were the rule. Wild game supplied meat, and many families went weeks at a time without bread. Corn was pounded on rude hominy blocks. ${ }^{10}$

Lcading products.-Corn prompty became the staple crop. ${ }^{11}$ It was easy to cultivate, and peculiarly fitted to the prairie soil, returning a large yield. The harvest was long, an important consideration on the

${ }^{1}$ Illinois in 1837,1 . 14 .

2 Ferris: The state and Territories of the Great West, pp. 209-210.

1Iall: Statistics of the West $(1836)$, p. 103.

4 Beck. Gazetteer of lllinois and Missouri, P. 18; 111 inois in 1837, p. 96; De Bow's Review,

V. $19, \mathrm{P}, 110$.

S latson: Reminiscences of Bureau County, pp. 267-268.

"Ellswarth: Recoril of the Olden Time, 1p. $246-2+7$.

7 Ford: History of Putnani and Marshall Counties, p. 197.

${ }^{5}$ Ellsworth: Record of the Olden Time, p. 246.

Peck: Guide for Emjgrants, p. 181.

History of Woodford County, p. 301; Matson: Reminiscences of Bureau County, pp. $151,155$. 


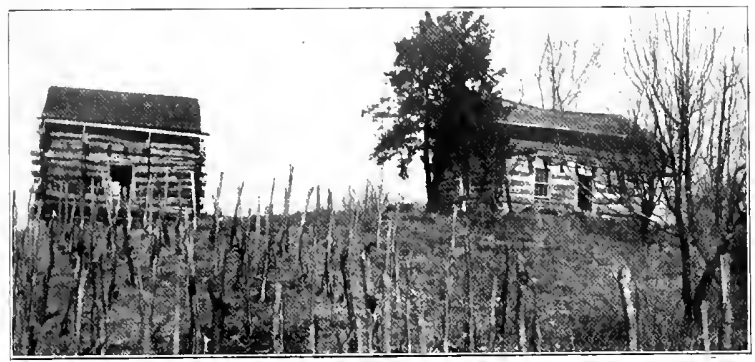

Type of early home in Illinois Valley. 

frontier where labor was scarce. It was easily stored, easily prepared for food, and possessed extremely nourishing properties for aninals and man. Wheat and other crops were grown to less extent.

The raising of swine and cattle becane important at an early date. The hogs obtained their own food in the oak timber which lined the Illinois and some of its tributaries, ${ }^{1}$ while much of this broken bluff land was soon thought to have a surface too rough and a soil too thin for successful cultivation." Furthermore, it was soon seen that "it was much easier to have the extra produce in the form of flesh, which would walk to market, than to have it in grain which had to be hauled." ${ }^{3}$ Stock was driven in considerable quantity to Chicago (especially from Fureau County) and to Galena, which was the supply depot for the important lead mining area in the northwestern corner of the State. As an auxiliary industry, cheese was extensively made along the Illinois, and found ready sale in St. Louis. ${ }^{*}$

Fences.-The development of stock raising brought the necessity of fences as protection for crops, and for years this need constituted one of the most serious problems of the prairies. Rails were used near the timber and were usually laid straight rather than in the form of the Virginia "worm fence," thereby reducing greatly the number required. ${ }^{5}$ The cost of rails rapidly increased with the distance from the woods, and they were generally abandoned in Bureau County by $1850 .{ }^{6}$ Boards were sometimes hatled from Chicago, but this likewise involved much expense as well as time. About 1850 the difficulty was largely solved by the introduction of wire fencing and the osage orange hedge. ${ }^{7}$

Mills.-Saw mills and grist mills constituted a pressing need of the settlers, and were among the first improvements made. As already indicated, lumber hauled from Chicago was extremely expensive, and yet lumber was in great demand for flooring, doors, and other uses. It was also a great inconvenience and hardship to be forced to pound grain on a hominy block, or to grind it in hand mills. For a time the nearest flouring mill to Putnam County was on Salt Creek in Sangamon County 80 miles away. ${ }^{8}$ The first flouring mill in Putnam County was established in 1828, near Florid. ${ }^{9}$ In 1830 a flouring mill was built on Kickapoo Creek, 3 miles west of Peoria, which did a thriving business for a time, but was undermined and carried away by the stream. ${ }^{10}$ Seven years later a second mill was started on the same stream, the machinery having been brought by wagon from Albany, New York.11 A saw mill was erected upon Kickapoo in $1835 .^{12}$ The first grist mill in Bureau

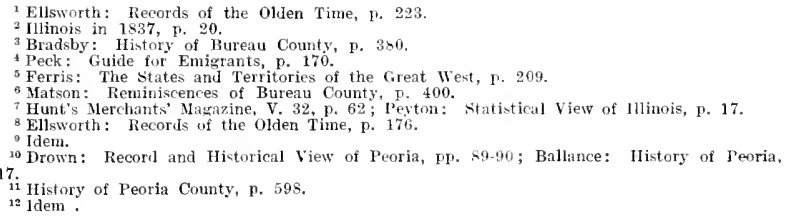


County was built on East Bureau Creek, in 1830; the machinery was largely of wood, and the mill stones were dressed from glacial bowlders taken from the neighboring bluffs. ${ }^{1}$ The following year the first saw mill of the county was erecterl on Big Bureau Creek. ${ }^{2}$ Mlany other mills were later luilt on these and other streams, although even in some of the larger ones, there was an adequate water supply for only two-thirds of the year." Nltogether some 47 water mills (31 saw mills and 16 flowing mills) were erected on the creeks of Bureau County, 30 of them on Pig Bureau Creek.* The great number of mills established, in spite of the relatively insignificant water power available, reflects their importance in the early economic life of the region. Largely because of the scarcity of fuel, few steam mills were established in the Illinois Valley in the early days. None harl been lutilt in $1831,{ }^{5}$ but one was built in Lacon in $1836,{ }^{\circ}$ and two started up in Peoria by $1837 .{ }^{7}$

Prices and markets.-Another very serious problem to the pioneer was getting his surplus produce to a market. At first there were no local markets. and steamboat navigation did not develop on the Illinois until the thirties. The farmers were therefore forced to take their corn, wheat, hams, and bacon on flat boats down the river to St. Louis. and often to New Orleans. ${ }^{8}$ Those who got down the river early might get a fair price for the produce, but the late comer was likely to find the marliet overstocked, and have to dispose of his cargo for little or nothing. The return trip from New Orleans with merchandise against the swift current of the Mississippi was a slow and most laborious process anit the farmer often preferred to sell for cash and walk home. Similar unsatisfactory conditions prevailed for years throughout the country dependent upon the western rivers. ${ }^{9}$ As population increased, farms were taken up farther and farther back from the Illinois, and roads were opened to the river, ${ }^{10}$ where at favorable places store houses and landings were established, usually by men from the East. This marlied the appearance of the local merchant and the beginning of the river towns. Noney was scarce and payment for produce was usually made in goods.

Settlers in Bureau County, and even in Woodford County, began as early as 1838 to haul their grain to Chicago, bringing back the much neerled lumber and salt. ${ }^{11}$ Each season during the following decade many farmers from the vicinity of Princeton started across the prairie after harvest when the roads were best, with 35 or 40 bushels of grain

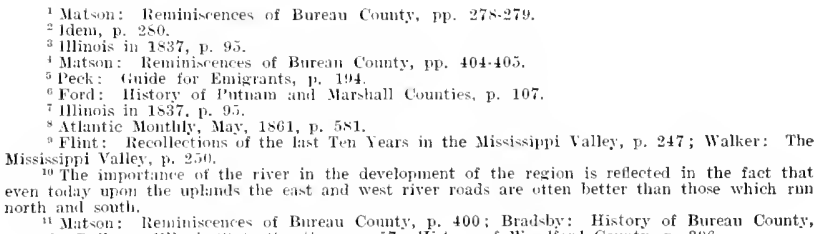

10 The importince of the river in the development of the region is reflected in the fact that even todiy unom the uplands the east and west river roads are utten better than those which run

it lation: lieniniscences of Burean County, p. 400; Bralsby: History of Burean County, north anil south. p. 162; Bailey: Illinoix titute Gazetteer, p. 77 ; History of Wuelford County, p. 396. 
to a load on the ten day trip over 100 miles to the lake. ${ }^{1}$ The wagon trade with the interior was an important factor in the early growth of Chicago. In 1836 in a single day 127 wagons were counted in its streets, loaded with merchandise for the country." The first shiment of grain ( 78 bushels) was made from Chicago in 1838. The shipment was 3.672 bushels in 1839) 10,000 bushels in $18+0$; 40,000 bushels in 1841 ; 586,907 bushels in 1842; and in 1847 when Chicago was still connecterl with the interior only by wagon roads, $2,24,3,201$ bushels. ${ }^{3}$

The distance of the midile Illinois Valley from large markets both to the west and the east, together with the cost of land transportation, meant high prices for merchandise and low price for produce. Wheat often brought only 25 to 37 I/2 cents a bushel, and sometimes less, when delivered at Chicago." Nevertheless, produce appears to have been generally higher and merchandise lower in Chicago that at St. Louis. This was probally due to the superior connection of Chicago with the East by way of the Great Lakes and the Erie Canal, as against the eastern connections of St. Louis through Pittsburg or New Orleans by rivers whose navigation was uncertain. These differences undoubtedly influenced the development of the Chicago wagon trade. The farmer tracting with Chicago did not actually realize the prices indicated, however, for he had to subtract the expense of the long trip to the lake and the value of the time of team and driver. For the most part, the counties under discussion continued to be dependent on Illinois River and St. Louis, until the opening of the Illinois and Michigan Canal in 1848. The difficulty of transporting products to a satisfactory market was general in Illinois, and had created a strong demand for internal improvements. ${ }^{5}$

\section{River Towns and Trade.}

Physiographic conditions determine torn sites.-The rise of the river towns and the development of steamboat navigation went hand in hand. Both the nature of the first demand for river towns and the conditions which determined the location of the more important ones, have been briefly referred to in preceding pages. A landing, a warehouse for grain, a general store, a blacksmith shop, one or all of them, were established at points convenient to the back country and accessible from the river. This simple beginning became the center of a ciuster of houses and the nucleus of a town. Every important river town in the area is situated upon the edge of a terrace against which the river swings, and every such terrace has a town. It will be remembered that the presence of the stream on the terrace side of its flood-plain is in every case brought about by the deposits of a considerable tributary

${ }^{1}$ The route from Princeton naturally led straight across the prairie to Chicago, diagonally across sections of land. Is the intervening area settled up, however, the land holders fenced the road out, increasing its length. The Bureau cuunty people interested in the Chicago wagon trade regarded as serious any increase in the already long trip, and petitioned the Legislature for a straight roud. The petition met with approval, and the Princeton and Chicago state road was legalized. Matson: Reniniscences of Bueau County, p. 346; Bradsby: History of Bureau County, p, 162.

" Mitchell: Sketches of Illinois, p. 31.

${ }^{3}$ De Bow's Review, Second Series, V. 4, p. 115.

\# History of Hoodford County, P. 396 ; Braulsby; History of Bureau County, p. 162.

"Niles' Register, Sept. 12, is35; Le Bow's Review, V. 19, pp. 681-682; 'Walker: The Mississippi Valley, p. 258. 
opposite, the size of this tributary, in turn, being partly due to the fact that there was no terrace on its side of the valley. Such terrace sites were high enough to be healthful and safe from floods, but not so high as to make loading and unloading from boats difficult.

Short lived river tow'ns.-At least two river towns were founded within the area of the report, whose sites are now vacant. Webster was founded in 1836 about 2 miles north of Henry. By the autumn of 1837 it contained a population of over 100, and boasted hoth a saw mill and grist mill, in addition to a grocery and a blacksmith shop. In 1838 , the location proved to be very unhealthful, and the inhabitants began to leave. The town was entirely abandoned in $18+2$, and the houses were gradually removed or destroyed. ${ }^{1}$ West Hennepin was laid out in 1836 on the Illinois bottoms opposite Hennepin. For a few years it carried on a considerable river trade in pork and grain, but being subject to inundation it soon ceased to grow, and was destroyed by the decline of river commerce and by the railroads. ${ }^{2}$

River toc'ns precede inland towns. - IVith very few exceptions the inland towns of the area were founded later and grew less rapidly than the river towns. This was because the former, until the advent of the railroads, afforded no market. As late as 1850 the aggregate population of the inland towns of the six counties was less than 3,000 , only 31 per cent of that of the towns located on the river." More than a dozen of the present inland towns were not listed in the census returns.

Early history of Peoria.-The value of the site of Peoria was evident to the Indians. The roomy terrace at the lower end of a lake abounding in fish, the springs, the narrows in the river where it was easily crossed, and the fertility of the surrounding land, appear to have formed an attractive combination. At different times important villages were established here and in the neighborhood by Indians whose presence is recorded by the name of the present city, by the names of Kickapoo and Black Partridge creeks, and of other geographic features in the vicinity. Indian trails focused upon the river at this point, among them the warpath which ran from the Wabash to Des Moines River. ${ }^{4}$

Peoria was visited by Marquette in 1673 , and six years later LaSalle built Fort Crevé Coeur on the opposite bluffs. A French settlement was established as early as $1725,{ }^{5}$ and to the end of the French period it constituted a connecting link between their establishments on the Great Lakes and the Mississippi. The French traders at Peoria did a thriving business with the Indians in deer, beaver, otter, and mink skins, ${ }^{6}$ so that the place was said to be the most important trading point in Mississippi Valley. ${ }^{7}$ The French village was destroyed by an Ameri-

${ }^{2}$ Ford: History of Putnam and Marshall Counties, pp. 121-123.

${ }^{2}$ Bradsby: 1Fistury of Bureau County, p. 437; Ford: History of Putnam and Marshall Counties, p. 89.

A Frenchman named Beuro built a trading house on the west bank of the river prior to 1790 Each spring for some years lie sent canoes loaded with furs and buffalo skins down-river to the lower markets. Bureau County takes its name from hiru. Mlatson: Reminiscences of Bureau County, p. 276

3 Compendium of the Serenth Census, p. 336 et seq.

4 Drown: Record and Historical View of Peoria, p. 125

5 Bateman and Selby: Historical Encyclopedia of llinois, p. 418

* Ballance: History of Peoria, p. 210.

7 Bateman and Selby: Historical Encyclopedia of lllinois, p. 418. 
can force during the War of 1812 , because it was supposed that the inhabitants were in league with certain troublesome Indian tribes of the region. At that time the population, estimated at between 200 and 300 was composed of French traders, hunters, and voyageurs, together with a considerable number of half breeds and Indians. ${ }^{1}$ The next year Fort Clark was built upon the site of Peoria, and in 1819 the permanent American settlement began, the first settlers, as already noted ( $p$. 74), coming from the Shoal Creek seltlement, 40 miles east of St. Louis. ${ }^{2}$

Peoria was credited with the best town site and harbor in the entire west, ${ }^{3}$ and in consequence of these advantages and the fertility of the surrounding country, it was predicted as early as 1823 that it would become a city of the first importance. Nevertheless, the town grew very slowly during the first years. The American Fur Company, whose traders had passed from Lake Michigan to Illinois River as early as $1778,{ }^{5}$ established a trading post at Peoria in $1824,{ }^{\circ}$ but the fur bearing animals of the region were nearing extinction. Fishing in the lake afforled a basis for trade, ${ }^{7}$ but as late as 1832 flour for food and corn for planting had to be brought from St. Louis. ${ }^{8}$ In 1833 it was still a village of only about 25 families, ${ }^{9}$ most of whom lived in log cabins. ${ }^{10}$ The following year it began to grow rapidly, ${ }^{11}$ and by 1837 it was said to have a population of about $1500 .^{12}$

Advent of steamboat and development of river tozuns. - The development of steamboat navigation on the Illinois was one of the most important events in the history of the valley. It created new towns and formed the basis of their growth; it stimulated the growth of its agricultural population; and it greatly increased the products and the prosperity of the region.

The first steamboat upon the western rivers was built at Pittsburg in 1811 , but 17 years passed before the first one appeared on the Illinois. ${ }^{13}$ Till then the limited trade of the Illinois was carried on in canoes, pirogues, flat and keel-boats. ${ }^{14}$ The first steamboats on the river ran up only to Beardstown, founded in 1829 about 90 miles above the mouth of the stream, at the point which was, for a time, the head of navigation for the larger New Orleans steamboats. ${ }^{15}$ Beardstown enjoyed a large trade. In 1831 steamboats arrived from St. Louis almost daily, and it was estimated that more passengers and goods were landed there than at any other point on the river. So recently and rapidly had it become important, however, that is was scarcely known south of $\mathrm{St}$.

${ }^{1}$ Batenan and Selby: Historical Encyclopedia of Hlinois, p. 418; and Edwards: History of Illinois, pp, $65-66$.

'Drown: Record and Historical View of Peoria, pp. 75, 81; Ballance: History of Peoria, p. 47 .

${ }^{3}$ Edwards: History of lllinois, p. 66 .

- Beck: Gazetteer of Mllinois and Missouri, p. 147.

5 Magazine of Western History, V. 12, p. 506.

'Bateman and Selby: Historical Encyclopedia of Illinois, p. 419.

7 Beck: Gazeteer of Illinois and Missouri, p. 119.

${ }^{8}$ Ballance: History of Peoria, p. 211.

Peck: Gazetteer of lllinois, p. 270.

${ }^{10}$ Hunt's Merchants' Magazine, V. 41, p. 658.

11 Hoffman: A Winter in the Far West, V. 2, p. 57; Tanner: View of the Mississippi Valley, p. 228 .

i2 Illinois in 1837, p. 138: Gazetteer of lllinois, p. 270.

${ }_{13}$ Mitchell: Sketches of Illinois, p. 14; 1llinois in 1837, p. 34 .

14 Davidson and Stuvé: History of lllinois, p. 348 ; History of Peoria County, p. 526.

15 Illinois in $1837, \mathrm{p}$. 115 . 
Louis, and a consignment of goods from the East markel "Beardstown. Ill.," remained for some time at Shawneetown on the Ohio where it had been landed by mistake, because the inhabitant of that place did not know where Beardstown was. ${ }^{ \pm}$

The first steamlont to reach Peoria arrived in December, 1829. Another came in the following spring. Three different steamboats were running there in $1833 ; 7$ in 1834 ; and 44 by $18+0 .{ }^{2}$ The great lend of the river at Hennepin was reacher by the first steamboat that went above Peoria, in May, 1831, and by a second in the following September."

There was no occasion for the first steamboat which reached Peoria to go berond that point, for not a town existed on the river above. During the next seven years De Pue (then called Trenton). Hennepin, Henry, Lacon, and Chillicothe were all founded. ${ }^{*}$ They repended almost exclusively upon the river trade in grain and meat, and substantial growth in most cases came only when steamboats became common above Peoria in the forties. Business depression following the panic of 1837 also retarded their growth.

The first building upon the site of Hennepin, a store, was erected in 1831, the goods having been bought in St. Louis, brought to Pekin by hoat, and hatled from there by land. ${ }^{5}$ In the forties ${ }^{6}$ and fifties ${ }^{7}$ Hennepin had a large river trade in grain. An early attempt to draw trade from the west side of the river by establishing a ferry was stoutly opposed by the merchants of Princeton. Finally the people in southeastern Bureau County demanded an outlet by the river, and the ferry, together with an embankment leading to it across the flood-plain, was provided. Important conmercial cities frequently develop at conspicuous bends in navigable rivers, for at such points much traffic is likely to change from water transportation to land carriage, and vice versa. The early commercial importance of Cincinnati and Nashville was due, in no small degree, to their location at great bends of the Ohio and Cumberland rivers. In view of this, it might, at first thought, be supposed that its location at the great turn in Illinois River should have given Hennepin a more rapicl growth than it experienced. It is clear, however. that in general only up-river traffic, seeking points to the northward. and down-river traffic seeking points to the westward of the bend of the Illinois, would leave the river there, and that the area to the northwest of the turn that would find its nearest river point at the bend, would be much larger than that to the southeast. In a word, towns of this tripe normally develop, as in the case of Cincinnati and Nashville, on the outside, and not the inside of the bend in the river. In the case of the llinois, however, the inviting terrace was on the inside and here Hennepin was founder, while the land adjacent to the

\footnotetext{
Jlinnis Munthly Mrumaine. V. 2, pp, 100-101.

-Drown: Recotil ami Iljturical View of Peoria, D. 107: Peck: Guide for Emigrants, p. 322. ก. 294

${ }^{3}$ Bradsby: History of Bureau County, p. 116; Hatson: Reminiscences of Bureau County.

4 Buteau is not moperly a river tomn, but was createrl by the business of the railroad junction.

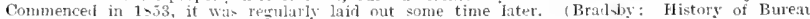
Ciounty. P. 437.)

Ellsworth: Records of the OIden Time, p. 161: Ford: History of Putnam and Marshall Counties, $p, 47$

Ford: History of Putnam and Harsball Counties, p. 89

Hawes: 1llinois state fiazetteer. Pp. 106-1 th ก. 266.

Ellaworth: Reonits of the Olden Time, 1, 1fi4; Matson: Reminiscences of Bureau County.
} 
river upon the outsicle was low flood-plain subject to anmual overflow. The disadvantages in the location of Hennepin nay lave influenced the founding of West Hennepin (p. 84), though this is mere conjecture.

The site of Henry was chosen and a ferry license obtained by 1831.1 A heary business was carried on in grain after $18+4,{ }^{2}$ and to invite tratle from the east sicle of the river a briclge and a dike through the bottom lands were built." Henry may have benefited at times by the fact that it was considered the head of low water navigation from St. Lonis."

Lacon was laid out in $1831 . "$ nany of its early settlers coming from Ohio." The village promptly hecame an ontlet for the surrounding grain producing country, and as early as 1837 was lescribed as a "thriving little town." " It adranced most rapilly after 1850 ," and promised to lecome, after l'eoria, one of the most important points on the river. ${ }^{9}$

Rome, founded in 1832 and regularly visited by steamboats in 1835 , never recovered from the effucts of the panic of $1837 .{ }^{10}$

De Pue (Trenton) was the fifth river town established north of Peoria. In 1835 a large warehouse was built on the edge of a low terrace on the north shore of Lake De Pue. The following year two other storehonses were erected, and the place at once became the shipping point for a large area to the west of the river. As in the cases of the preceding towns, the grain was sent to St. Lonis until the opening of the lllinois and Michigan Canal in 1848. ${ }^{11}$

Chillicothe was laid out at the head of the upper Lake Peoria in 1836, some time after the first building was erected on the site. ${ }^{12}$ It had a fine steamboat landing, and became a typical grain shipping town. ${ }^{13}$ The need of an ontlet for the farmers living on the east side of the river between Chillicothe and Peoria led to the founding of Spring Bay in 1838. For 20 vears after $18+4$, Spring Bay was one of the most important grain markets on the river, and a lumdred wagons were often seen on its streets in a single day. ${ }^{14}$

Pekin, to the south of Peoria, clates from 1828, and the name indicates the future greatness which its founders felt the advantages of its situation insured. ${ }^{1 ;}$ The place was injured by a visitation of cholera in 1834, but most of Tazewell Comnty was commercially dependent on it, and it therefore developed a very large river trade.

Each one of the above river towns constituted a gateway between an agricultural community and the outside world, and its early importance

\footnotetext{
1 Ford: History of Putnam and Marshall Counties, p. 111.

2 Iden, P. 113.

3 Iden, p. 11.

+ Hawes: 1llinois state fazetteer, p. 107.

5 Ford: History of Putnam and Marshall Counties, p. 105.

Idem, p. 106 .

Illinois in 1837, 1. 99; Peck: Gazetteer of Illinois, p. 236.

s Ford: History of Putram and Marshall Counties, pp. 109-110.

- Hawes: Illinois State Gazetteer (1858-9), 1'. 123.

${ }^{10}$ History of Peoria County, p. 582.

13 Taxpayers and Voters of Bareau County, p. 159; Bradsby: IIintory of Bureau County,

12 History of Penria County, p. 577.

13 Iden, P. 578 ; Hawes: Illinois State Gazetteer (1858-9), p. 61.

14 History of Woodford County, pp. 305-306.

15 Baitey: 1llinois State Gazetteer $(1864-5)$, p. 500.
} p. 43.5 . 
was in general measured by the extent, population, and productivity of its tributary hinterland. A number of conditions to which attention is now directed gave Peoria preëminence.

Peoria hecomes the leading toz'n on Illinois River.-Peoria grew from the first more rapidly than the other towns of the area. In 1850 its population was more than twice the combined population of the others. ${ }^{1}$ A number of causes had produced this result: (1) Its centrat location; (2) the early building of roads from the city into the surrounding country; $(3)^{\circ}$ the establishment of the first ferry, and later the first bridge across the Illinois; $(4)$ the focusing upon the river at this point of important roads from other parts of the State; (5) the influence of certain special lines of trade in fish, ice, and coal : and (6) the fact that many steamboats did not run above Peoria.

(1) While it holds a marginal position with reference to the river towns of the six counties with which this report is chiefly concerned. it is very centrally located with reference to the valley as a whole, ${ }^{2}$ and particularly in relation to Chicago and St. Louis, being almost exactly midway between the two. This meant that communication could be had from Peoria with all other towns on the river, with less travel than it could from any other town, with all the rest. This central location helped powerfully to make Peoria the dominant commercial center, and later the wholesale distributing center for the valley. Wholesale business houses were established as early as $1842 .^{3}$

(2) Attention was given very early to the building of roads and bridges, thus extending the sphere of commercial influence of Peoria, and bringing produce nearer a market. Provision was made for the opening of roads from Peoria to the borders of the county in 1825.* The spread of population beyond Kickapoo Creek called for bridges across that stream, and the first one was completed by $1830,{ }^{5}$ and three others by $183 \%^{\circ}$ In general wagon roads are late in being opened along the banks of navigable rivers, since traffic moving parallel with the stream can use the water; and in this connection it is worthy of note that as late as 1838 no road ran north from Peoria in the valley. ${ }^{\top}$

(3) Peoria established the first ferry across the Illinois, and so profited from trade and travel crossing the river. Such communication proved altogether inarlequate, however, and within two years after the incorporation of the place as a city, the citizens took steps toward the building of a bridge nver the river. ${ }^{8}$ The position for the bridge was indicated by the constriction in the river produced by the fan of Farin Creek. It was completed in November, 1849 , and together with the trestle work over the flood-plain was a half mile in length. The city

Compendium Seventh Census, p. 335 et seq.

2 Peoria is also not far from the geographical center of the State, which is periaps the most inportant claim it advanced in 1843,1847 , and 1867 , for being made the state capital. History of Peoria County, r. 454; Drown: Record and Historical View of Peoria, pp. 97-95.

${ }^{3}$ History of Peoria Cunnt, p. 564.

* Idem, pp. 30ti-307.

I Iem, p. 323

Glinois in $1 \rightarrow 37$, I. 9.

Jones: Illinois and the West, pp. 171-172.

Hunt's Merchants' Magazine, V. 41, pp. 696-697. 
at once felt the benefits of the bridge in added business; travelers and drovers, in order to cross the river without delay and in safety, found it advantageous to digress from their direct course to cross at Peoria. ${ }^{1}$

(4) Because of its central location on the Illinois and in the State, its growing trade, and the facilities for crossing the river, Peoria became one of the most important road centers in the State. Figure 40

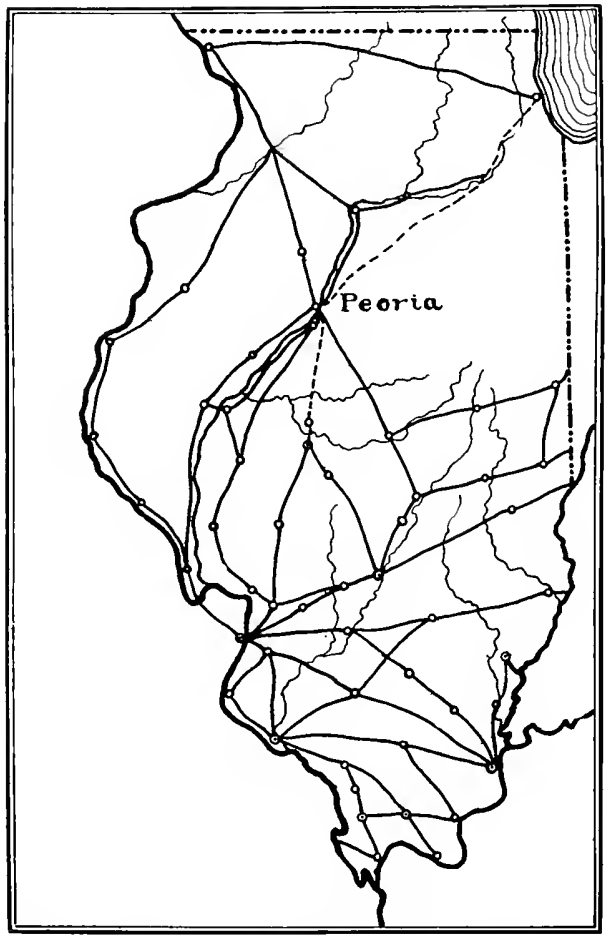

FIg. 40. Map showing roads of tllinois in 1832. (Baircl.)

shows the roads of Illinois in 1832. The number of roads focusing upon Peoria, the important places with which ther connected it, and the paucity of roads running to the other towns of the middle valley are points worthy of note. Peoria became a great cross-roads between the

${ }^{1}$ Drown: Record and llistorima View of Peoria, p. 102. 
highwar of Illinois River, and various important land routes. Its importance as a collecting and distributing center increased rapidly. In 1848 it harl over 80 business establishments, ${ }^{1}$. which represented an increase of over 100 per cent in three years. ${ }^{2}$ Two years later its exports were valued at over $\$ 1,250,000 . ?$

In 1822, a mail route was opened from Edwardsville (northeast of St. Louis) through Springfield to Peoria. ${ }^{4}$ The northward extension of this road from Peoria to Galena becane one of the great thoronghfares of the West. A rush of miners and prospectors to the Galena lead region began in 1822 , when the mines were first effectively worked. ${ }^{5}$ The output of ore reached nearly 13 million pounds in $1828,{ }^{\circ}$ and by 1830 the poptuation was between 900 and 1,000. nine-tenths of which were men engaged in mining. ${ }^{7}$ In addition many went back and forth between the mines and the southern settlements each season.

This rapidly increasing mining population demanded food supplies in large quantities, and Galena hecame an important market for Illinois Valley, especially for Peoria and the farmers north along the line of the road in Bureau County. ${ }^{\mathrm{s}}$ The pioneer in the Galena trade was a man named Kellogg. who took three wagons and a drove of cattle across the prairies to Galena early in $1827 .{ }^{\circ}$ His route soon became a beaten track, which for years was known as Kellogg's Trail. Meats constituted an important item in the trade, and because of the distance of the market and the difficulty of transportation, cattle and swine were driven in large droves to Galena and slaughtered there. ${ }^{10}$ St. Louis was the great market for the Galena lead, which was taken down the Mississippi by boat; but much of the return travel and part of the return traffic was through Peoria and by Kellogg's Trail. This was a more rirect route in consequence of the great western bend of the Mississipppi along the boundary of Illinois, and avoided the slow up-river trip against the current. In 1831, the Galena stage left St. Louis once a week. ${ }^{11}$ Stages left Peoria for Galena three times a week in 1837, and shortly there were daily stages each way. ${ }^{12}$ Without doubt. Peoria derived much benefit from the Galena traile, especially down to 1845 , when the mining industry culminated.".

The other routes extending from Peoria (fig. 40) probably had less effect in the upbuilling of the town. That in some cases their business was not unimportant, however, is shown by the fact that as early as 1837 stages left three times a week for Chicago and for Springfield, and once a week for Knoxville. ${ }^{14}$

\footnotetext{
Western Tournal, I. I., p. 114

2Idem, p. 113.

"Drown: Recorel and 1[intorial view of peoria, p. 144

"Davden and sture: History of lllinois, p. 3is.

5 the Bow's Review. V. 19, pl. ton-409.

"Niles" Register, Hugrist 29 , 1nz9.

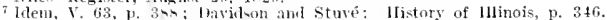

${ }^{8}$ Bradsby: History of Bureau County, pp. 175.176.

- Hatsm: Reminisences of Burean Counts, pp, 291-292.

un them: Bradsby: llistory of Bureau County, 1. 176; 11linois in 1937, p. 90.

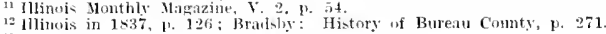

18 1llinoin Blue Bioh, 1900, $p, 141$.

${ }^{14}$ Illinois in 1837, i. 126 .
} 
(5) Certain minor factors aicled in the growth of Peoria. The fishing business in the lake, which was coeval with the settlement of the place, continued to be of some importance. ${ }^{1}$ The sending of ice downriver to St. Louis and other towns seems to have been a profitable business. ${ }^{2}$ Peoria also had a considerable trade in coal. The first shipment by river appears to have been in 1821 , when a boat loat was sent down the Mississippi to St. Louis." By 1850 some 20,000 tons were being exported each year. ${ }^{+}$

(6) Because of its superior importance, many steamboats from St. Louis did not rum above Peoria. This helped to make Peoria a distributing point for the towns to the northward, for freight on such boats consigned to up-river towns had to break bulk there.

While certain manufactures had started up in Peoria before 1850 , still its growth to that time was primarily due to its commerce. After 1850 the rapid development of its manufacturing interests and its railroad connections became large factors in its progress, and made more absolute its leadership in the valley. These matters are considered later.

The period of Illinois River steamboat.-The years 1835 to 1855 may appropriately be taken as marking the period of the supremacy of the steamboat on the Illinois. Before 1835 there were few boats on the river. ${ }^{5}$ After that the number increased rapidly. In 1836, thirty-five different steamboats passed Beardstown." It will be remembered that the beginning of the period coincides essentially with the beginning of the substantial growth of Peoria (p. 85), and in a general wav with the founding of several of the up-river towns. The exact date for the closing of the period is more or less arbitrary, but the importance of the steamboat trade on the Illinois promptly declined, both relatively and absolutely, with the appearance of the railroad in the valley.

The development of the steamboat business on the Illinois is registered roughly by the number of steamboats running to Peoria. In 1833 there were three and in 1834 only seven. In 1840, however, 4 different boats ran to Peoria; in 1841 around 60 ; and in 1844 about 150 . There were 694 arrivals of steamboats in $1845 ; 871$ in $1846^{\circ}$; about 866 in $1847 ; 1,166$ in $1848^{\circ}$; and 1,286 in $18500^{\circ}$ In addition to these, there was a large number of canal boats, ${ }^{10}$ barges and flat boats. In 1852 there were about 1,800 arrivals of boats at Peoria. ${ }^{11}$ The 1llinois seems to have compared very favorably in commercial importance with the other great western rivers, judging from the number of steamboat arrivals from different points at St. Louis, which, because of its position near the mouths of Missouri. Illinois, and Ohio rivers, and at

${ }^{11}$ Western Journal and ('ivilian, X. s., Y. 3, p, 349,
} 
the point where bulk was broken between the ligher draft boats of the upper Mississippi and those of hearier draft operating on the lower $M$ ississippi, had become the greatest steamboat center on the western waters, with the exception of New Orleans. ${ }^{1}$ The following table ${ }^{2}$ shows the steamboat arrivals at St. Louis for four typical years:

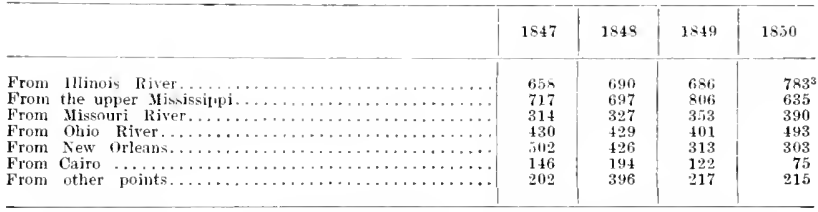

It will be noted that Illinois River led in 1850 , in spite of the fact that produce from the middle valley was moving through the IllinoisMichigan Canal to eastern markets.

Until the opening of the Illinois-Michigan Canal all the exports of the middle Illinois Valley save those sent overland to Chicago and Galena, went down llinois River. The trade of the valley was an important factor in the growth of St. Louis. It has been seen that St. Louis was a great point of departure for settlers going into Illinois Valley. ${ }^{*}$ In 1835 merchants could purchase exchange to any amount on the East only in St. Louis, and there they bought all their goods. St. Louis merchants were connected as owners or agents, with all the Illinois steamboats. These boats required up-river as well as clown-river cargoes, and the former could be obtained only in St. Louis. ${ }^{5}$ Such close commercial connections continued until $1848 .^{\circ}$

\section{The Illinois and Michigan Canal.}

A new and powerful factor in the economic life of Illinois Valley appeared in 1848 in the form of the Illinois and Michigan Canal, to which reference has already been made. The canal opened new markets, brought the valley into closer relations with Chicago and the Great Lakes, and modified its life in important ways. The people of the middle valley had before faced for the most part toward the west; from now on they found their closest relations in the east. The salient factors in the history of the canal are next considered, insofar as they affected the area under consideration.

Physiographic processes make canal fasible.- Had the degradational work of the Chicago Outlet (p. 4t) continued, the Great Iakes would have discharged permanently to the southwest, and the early economic history of the midalle Illinois Valley would doubtless have differed notably from that slietched above. As it was, the waterway to

\footnotetext{
The Buw's Review. 1. 1, p. 147

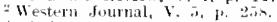

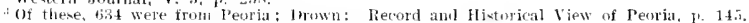

* Lllinois Munthly Magazine, V. 2, p. .t.

Forel: History of Illinuis, His, izfi 177.

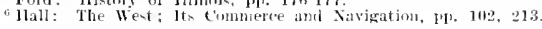


the southwest was frequently continuous after heavy rains, so that boats of 8 to 10 tons burden carried freight between Lake Michigan and Illinois River without portage. ${ }^{1}$ The first produce sent from Peoria to Chicago, a small consignment of provisions for the use of the Fur Company (1825), was carried all the way in boats. ${ }^{2}$

Dezelopment of canal project.-A canal between Lake Michigan ank Illinois River was first suggested by Joliet, a member of the first white party (1673) that passed along the Chicago Outlet. Albert Gallatin declared in 1808 that there was no doubt of the practicability of opening a canal along this line. ${ }^{3}$ Such a canal was consideresl a probability by a writer in Niles' Register in 1814, who predicted that it wonld nake Illinois "the seat of an immense commerce." It was agitated for two decarles in Illinois before work was finally begun in 1836 with the aid of large land grants from the govermment.

Results expected from the eanal.-It was expected that the influence of the canal would be far reaching and of the utmost importance. Its friends had urged that, among other things, it would open new markets by way of the Great Lakes, St. Lawrence River, and the Erie Canal, that it would lower transportation rates, increase the prices of produce and lessen the cost of merchandise, increase greatly the population, products, and value of the adjacent land, decrease the danger of sectionalism by drawing closer together Mississippi Valley and the Great Lakes and East, and yield a revenue sufficient to pay the expenses of the State government. ${ }^{5}$ Some of the anticipated results were realized, as shown below; others, notably the last, proved altogether extravagant.

Opening of the canal.--The Illinois and Michigan Canal was plannerl and in part constructed as a ship canal, capable of accommodatig the largest boats then navigating the Great Lakes. The lake level was to run ont at the site of Lockport, where the first locks would be located. Here it was expected an important nanufacturing and commercial city wonld develop, for which a name was selected (Lockport), indicating its advantageous situation with reference to both canal and lake." The expense of making the projected deep cut through the Niagaran limestone, however, and the heavy debts of the State. led to a modification of the plans. The canal had been given a depth of 18 to 20 feet for 30 miles: west of that, it was completer with a depth of only 6 feet. It is nearly 100 miles long. with its western end at La Salle, the head of navigation upon Illinois River.

The first boat to pass through the entire length of the canal from La Salle arrived at Chicago on April 23, 1848, with sugar from New Orleans. ${ }^{\top}$ The date (May 24, 1848) of the arrival of the first canal

\footnotetext{
${ }^{1}$ Beik: Gazetteer of lllinois and Miscouri, P. 20; Pullication X̌o, 8 of the Historical Library of Illinoic, p. 162; American State Papers, V. 20, 1. 735.

2 Drown: Record and Historical View of Peoria, p. 84 .

American State Papers, V. 20, F. 73\%.

+ Niles' Week1y Register, Y. 6, p. 394.

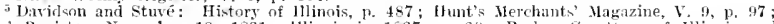
Niles Register. November 19, 1831; Illinois in 1837, P. 20; Beck: Gazetteer of Illimois and llissouri, pp. $27-35$.

Bailey: Illinois state Gazetteer, $(1864-5), \mathrm{p}, 47$.

T Report of the Board of Trustees of the Illinois and Michigan Canal, 184s, F. 2. The Annual Reports of the Board of Canal Trustees were published until 1869 in the Reports of the General Assembly of Jllinois. Thereafter the rearly report of the Butrut of Canal Commissioners for lllinois to the Governor were published in segrarate form. These reports constitute the most satisfactory history of the canal.
} 
boat from Lake Michigan was "a llay of rejoicing and trimmph" in Peoria. ${ }^{1}$ During the remainder of the year 496 canal boats risited the city.2

Early traffic on the canal.-Lumber was the most important article brought into the Illinois valley through the canal. It has already been commented upon as one of the greatest needs of the prairies. Their occupation led to the exploitation, begimning early in the thirties, of the great forests of Mlichigan and Wisconsin. logs cut in the interior were foated down all the streams of Mlichigan, which flow toward the west. At the mouths of these rivers busy towns developed where the logs were manufacturet into lumber. St. Joseph built what is said to have been the earliest steam mill in Western Michigan in 1832, and Muskegon built one in 1837, while Grand Haven, Manistee, and other points also became important lumber centers. The manufactured lumber was transporter across Lake Michigan at low rates to Illinois. ${ }^{3}$ By 1839, mills had started up on the shores of Green Bay. WVisconsin, which soon began to send their product south to the prairies."

Practically all the lumber for the prairies passed through Chicago. The first shipment appears to have been received there in $1833,{ }^{5}$ but not until 1836 was there any active demand from the interior." Until the opening of the camal, Chicago sent lumber into the interior only in wagons, by which it was sometimes carried 200 miles or more. In 1845 over 22 million feet of lumber in addition to quantities of shingles, lath, and fencing material were received at Chicago." Because of the cost of wagon transportation, pine lumber from Chicago was scarce and very expensive in the middle lllinois Valley. The alternative source of stipply for pine was the forests of the Allegheny in western New York and Pennsylvania. ${ }^{9}$ Lumber was brought from there to Peoria by way of the Ohio, Mississippi, and Illinois rivers. ${ }^{10}$ In 1838 , pine lumber sold in St. Lotnis from $\$ 50.00$ to $\$ 60.00 \mathrm{per} \mathrm{M}$, and in Peoria from $\$ 60.00$ to $\$ 70.00$; at inland points the cost of carting had to be adder..11 This price was prohibitive to the majority, who were compelled to use the less desirable timber growing in the valley. Even this sold at $\$ 25.00$ to $\$ 35.00$ per $M,,^{12}$ ant settlers at a distance from the streams sometimes built their homes of clay, roofing them with lumber. At about the same time medium quality pine sold for $\$ 12.00$ to $\$ 14.00$ in Chicago, ${ }^{13}$ and hefore the opening of the canal it fell to $\$ 9.00 .^{14}$

1. Jrown: Record and Itintorical View of Peoria, p. 103.

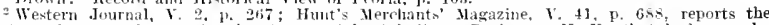
arrival on the same date at $\dot{k}^{2}$ oria of a canal hoat buit at Rochester. $N$. $Y$, that had come by way of the Erie Canal, Lake Erie, the Ohio and Erie Canal, and Ohio, Mississippi, and Illinots rivers. This illustrates the roundabout routes by which Peoria communicated with the East hefore the opening of the lllinois and Michigan Canil.

3ndustrial Chicago, Y. 4, p. $318:$ Y. 5, pp. $25,40$.

Idem, V. 5, p. 31; lina: The Great West, 1p. 107.14s.

sndustrial Chicago, V. 5, 1. 20.

"them, p. 19.

J Jen, pp. 43-4t.

s lilem, p. 3?.

\& Western Journal and Civilian, $x$. s., v. 3, pp, 222-23.

10 Hunt's Merchant, Mtumine, $Y$. 41, 1. $695 ;$; Peoria, T. 105 .

${ }_{12}$ Jones: Jllinois and the West, 1p. 207.20s

12 Jdem.

${ }^{13}$ Industrial Chicago, V. 5, p. 32.

1 Prairie Farner, V. 6, p. $296 ;$,, 7, p. 264. 
Upon the opening of the canal great quantities of pine and cedar lumber were taken into Illinois Valley. The cost of lumber was immediately reduced one-half at l'eoria, and further reductions soon followed. ${ }^{1}$ There was at once a notable change in the character and number of buildings erected. At Peoria, in 1848, 125 buildings were put up and 245 in 1849. ${ }^{2}$ The population of the city increased 67 per cent between 1847 and 1849. ${ }^{3}$ The canal gave a tremendous inpetus to the lumber trade of Chicago. The receipts in 1848 lacked only about $4,000,000$ feet of being double those of the precelling year. ${ }^{+}$In 1857 , they were over $459,000,000$ feet, and in the decade 18 \$8-1857 they amounted to more than 2,000,000,000 feet, in addition to enormons quantities of lath and shingles. ${ }^{5}$ The lumber business was for years the most important enterprise of Chicago. ${ }^{6}$ It was said that the receipts of 1856 required the services of a fleet equal to 166 first class brigs. ${ }^{7}$ Chicago lumber merchants established yards at Peoria, Pekin, and other river towns, ${ }^{8}$ and delivered lumber by canal boats as far west as Lexington, Missouri, and Ft. Leavenworth, Kansas." The lumber trade of Chicago and the canal and river was injured to some extent by the exploitation of the pineries of the upper branches of the Mississippi. In the fifties lumbering was extensively carried on along the LaCrosse, Black, St. Croix, and other Mississippi tributaries. Each spring the product of the winter's work was floated down-stream to St. Louis and other narkets. ${ }^{10}$ Large quantities of this northern pine were later sawed in Illinois mills along the Mississippi, especially at Rock Island and Moline, ${ }^{11}$ and in 1885 the canal commissioners complained of the "diversion of the lumber trade of Illinois River." ${ }_{12}$ Receipts of lumber in Illinois Valley by rail from Mississippi River points lad grown so large as to serionsly affect the business of the canal. ${ }^{13}$

Although a great number of clifferent articles were brought from the East by canal to the niddle 1llinois Valley, only agricultural implements, machinery, general merchanclise, and salt, in addition to lumber, were of any great importance. Great quantities of salt were required in the meat industry of the river towns (p. 109). Between 1850 and $1865,628,776$ barrels of salt were transported on the canal. ${ }^{14}$ The canal gave an important impetus to the salt industry of New York, Onondaga salt competing with Kansas salt as far west as St. Lonis. ${ }^{15}$

+ 1847, 32,118,225 feet; 1848, 60,009,250 feet. Hunt's Merchants' Magazine, V. 40,

"Idem. The year following the opening of the canal, Chicago's first railroad, the Galena \& Chisago Union, was openti to DesPlaines River, and the number and length of the railroads radiating from the city increased rapidly during the next few years (FIG. 44). In the long run the railroads were the most potent factor in the growth of the lumber trade of the city, but for some years the canal was much more important. Industrial Chicago, V. 5, p. 50 . 
East bound traffic through the canal was of two general classes. (1) southern commodities seeking a northern and eastern market, and (2) surplus products from the lands bordering the canal and the nearer western rivers to which it led. Illinois River and canal became at once an important trade route between the lower Mississippi and the Great Lakes and East, through which large quantities of sugar, molasses, hemp, and tobacco were shipped. ${ }^{1}$ The prices of these articles were doubtless much lower than formerly along the Illinois. In the second class of commodities corn, ${ }^{2}$ pork, bacon, hams, and lard led. ${ }^{3}$ Whiskey from the Peoria distilleries was also an important item. It had been expected that the opening of the canal would lead to a large development in coal mining along Illinois Valley, but although some coal was sent from the interior to Chicago. Pennsylvania coal, in consequence of its superior quality and cheap lake transportation, dominated the market. The following table shows the leading items in the canal trade between 1850 and 1865 , together with the amounts transported:

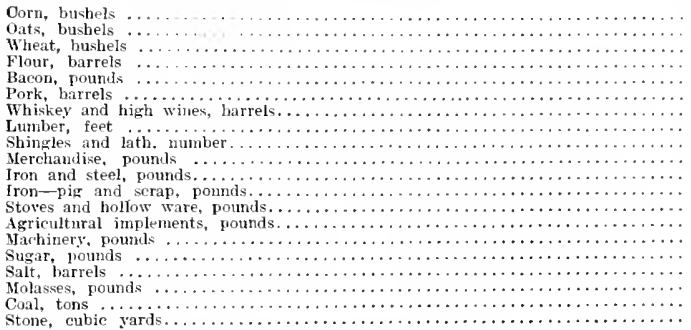

- $3,204,570$ $15,040,447$

$8,728,161$ 829,228

$10,309,838$ 155,953 65,986

1. 1122, 708,754 $754,960,791$

$77,160,555$

$8,888,186$

$22,967,580$

11, 222, 387

$7,749,252$

$5,593,917$

$5,907,586$
4 628,776

$14,519,385$ 192,975 955,779

The canal made travel to Illinois V'alley less expensive and more agreeable. The trip between Chicago and Peru was four hours shorter than it had been by stage and the fare upon the best boats was only $\$ 4.00$ including meals and berth. A slower line of freight and emigrant packets clarged $\$ 2.00$ to $\$ 3.00 .^{5}$ Three packets started daily from each end of the canal in $1849,{ }^{\circ}$ during which year the travel was equivalent to 26,446 passengers carried its entire length. ${ }^{7}$ At Peru the traveller could secure steamboat transportation to St. Louis for from $\$ 3.00$ to $\$ 5.00$. $^{8}$

1 Annuat Report of Boaril of Trustees, 1865, pp. 50-51.

2 The canal made Chicago the leading corn market as well as the leading market for lumber. In 1851 the lake ports that shipped east most heavily through the Erie Canal and the quantities of corn they contributed were:

Chienate th.

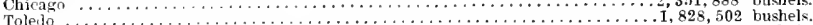

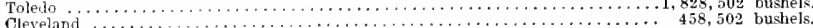

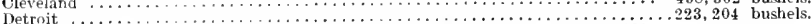

Benton: John Hopkins University Studies, Series XXI, Nos, 1-2, p. 103.

3 Annual Report of Board of Trustees, 1865, pp. $50-51$.

4 J dem.

5 Curtiss: Western Portraiture, p. 62; Industrial Chicago, V. 4, p. 299.

${ }^{8}$ Chicago Daily Democrat, Mlay $3,1849$.

${ }^{7}$ Rejort of Board of Trustees. I849, p. I0.

8 Curtiss: Western Portraiture, p. 76. 
Influence of the canal upon the course of trade.-The opening of the Illinois and Michigan Canal precipitated a struggle between Chicago and St. Louis for the trade of Illinois Valley and the West. It was generally anticipated that the great bulk of the produce of the valley would move eastward, and that Chicago would become the great depot for Illinois River. ${ }^{1}$ St. Louis was accorlingly opposed to the canal project, ${ }^{2}$ and even the merchants of New Orleans were alarmed. ${ }^{3}$

For some three years following the opening of the canal, St. I.ouis prices were in general higher than those at Chicago, and in consequence the greater part of the grain, meat, and flour of Illinois Valley went south; canal boats coming from Chicago with lumber, merchandise, and salt were at times unable to secure return cargoes along Illinois River. ${ }^{4}$ A similar situation occurred in 1856 because of a partial crop failure in some of the southern states. ${ }^{\bar{j}}$ This illustrates the tremendous advantage to the valley of the new order of things; there was now a choice of markets, and its produce could be sent wherever it would bring the largest returns. The course of trade during the years mentioned proved the exceptional rather than the normal thing. In general the results that had been anticipated were realized, and the trade of the Illinois was reversed, Chicago becoming its great market. ${ }^{6}$ The leading commercial journal of the West noted in 1852 that "as a grain market, St. Louis is becoming less and less important." " That year Chicago received nearly four times as much corn as St. Louis, practically all of it by the canal. ${ }^{8}$

It is not to be understood that the diversion of trade under liscussion was brought about entirely by the Illinois and Michigan Canal, nor that it was confined to Illinois. "The canal began it, so far as middle Illinois was concerned, but it was continued on a vaster scale by the railroads that, in the fifties, were built west from Chicago. A similar change was in progress in adjacent states. The Wabash and Erie Canal reversed the trade of Wabash Valley, and relieved Indiana of all economic dependence on the southwest. ${ }^{9}$ The shipments to the north on the Ohio canals were greatly in excess of those to the south. ${ }^{10}$ New Orleans was described in 1850 as a city which "once the emporium and mart of the immense empire of the west, sees her commercial rank and position fading away." 11 Ten years later the receipts of grain at Chicago were nearly ten times those at New Orleans. ${ }^{12}$

1 Hestern Jumrial, V. 6, pp. 167-168; Hofinan: A Wintel in the Far Hest, T. 2, P. 59.

Western Journal, Y. 6. Pp. 167-168; Chicago Daily Democrat, January 27, 1849.

1dem, November 24, 1848 .

t Annual Report of Board of Canal Trustees, 1848, pp. 155-1.56, 1850, pp. 8-9, S6; Western Journal, V. 6, pp. 167-168, 170 .

Chicago Magizine, V. I, p. 27.5.

${ }^{4}$ De Bow's Review, r. 15, p. 374 ; Curtiss: Western Portraiture, pp. 45, 47; Gould's Perria Directory, $1880-1$, p. 3.

7 De Bow's Review, V. 14, p. 394.

8 Chicago's receipts were $2,999,011$ bushels (Pejton: Statistical View of 1Ilinois, p. 39), and St. Louis' 755,258 hushels (Eighth Census, Agriculture, p. clvi)

${ }^{9}$ Benton: Johns Hopkins University Studies, Series XX1, Nos. 1-2, pp. 104-105.

se Eighth Census, Agriculture, p. clviii.

11 Western Journal and Civilian. N. S., V. 1., pp, 4-6, 113.

12 Eighth Census, Agriculture, pp. clvii, civiii. 
A number of considerations hat enabled the Illinois and Mlichigan Canal to reverse the trate of lilinois Valley, some of which explain in part the corresponding change in neighboring areas. (1) It was cheaper to ship grain in bulk by canal boats, than in sacks (the usual method) by steamboats. ${ }^{1}$ (2) The facilities for receiving and forwarding grain at Chicago were superior to those at St. Louis. Chicago had 12 large grain warehouses by 1857 and charged lower storage and commission fees. ${ }^{2}$ (3) It was said that grain could be shipped from a point on the lllinois to Chicago as cheaply as to St. Louis, and that the charges from Chicago to New York were not greater than those from New Orleans to New Jork. This, if true, obviously gave Chicago the very considerable advantage of the freight charged between St. Louis ancl New Orleans. ${ }^{3}$ In the middle fifties (1854), long distance freight rates on the Great Lakes were only about one-half as high as on the western rivers. ${ }^{4}(t)$ Save in exceptional years the prices of farm products were higher and those of merchandise lower in Chicago than at the Mississippi cities (p. 83). (5) There was (langer in summer of the grain being heated and damaged in the warehouses of New Orleans, and during its passage through the Gulf of Mexico. (6) Transportation by the round-about southern route took much longer. (7) The superiority of New York over New Orleans as an importing point, due in large part to its relative nearness to Europe, and its umparalleled connections with the interior by way of the Hudson-Mohawk depression and the Great Lakes, made it also a mere desirable exporting point, since the competing ocean lines offered lower freight rates.

By making it the gateway of Illinois Valley, the Illinois and Nichigan Canal became a powerful factor in the growth of Chicago. ${ }^{6}$ The imports of the city increased from about $2 \frac{\mathrm{r}}{2}$ millions in 1847 to over $8 \mathrm{I} / \mathrm{miltions}$ in $18+8$, the first year of the canal. The exports increased from a little over $2 !+$ to neary $103+$ millions in the same time. ${ }^{\top}$ The canal helped Chicago to become, in the early fifties, the largest grain and lumber market in the work. ${ }^{8}$ The population of the city rose fron 16,859 in $1847^{9}$ to 60,652 in $1853 .^{10}$

${ }^{1}$ Brown: Dranage Channel and Waterway, p. 205.

Chicago slagazine, V. I, p. 275.

${ }^{3}$ De Buw's Reriew, Y. 14, p. 314.

${ }^{4}$ Jlem, V. 19, pp. 196-147; V. 20, pp. 80-81.

${ }^{5}$ Eighth Census, Agriculture, $p$, clvif.

Chirago Magnzine. V. 1, p. 369.

1) Briw's Reriew, Y. 13, p. 190.

8 Peyton: Statistical View of llinois, p. 43.

De Bow's Review, Y. 13, p. 198.

${ }_{10}$ Peyton: Statistical View of lllinots, p. 36

The develomment of a commercial city near the end of Lake Michigan that should serve as a point of contact between the manufacturing and commercial east, and the agricultura] west, was inevitahle, The harbor afforded by Chicago kiver and the line of the old Chicago outlet determined its exuct location. Althoun the harhor was an indifferent one, it gained ralue from the very paucity of natural harbors along the Lake Mlichigan coast. The advantages of this situation were jot generally recognized, however, until after the opening of the lllinois and llichigan Canal. lo 1823 Mlajor Long declarel that Chicago not only then offered no inducements to business neen, hut was likely at all times to thave a limited trade. (Niles' Register. V. 57. p. 3.5.) A lpading commercil writer, as late as 1843 , thought that the commercial metronolis of the creat Lakes was to develop on Jaumee Bay, Lake Erje, and that the most Chicago couli reasomably hope for was second place. (J. W. Scott: Hunt's Merchants' Magazine, 1. $9,0,4 f$.$) The events resulting from the ofvening of the eanal and the building of Chicago's$ 1.9, p. 4t.) The events resulting from the olvening of the canal and the building of Chicago's that Chicaro "is destined to be not simply the first city in the Mississippi Valley, but with probably three exceptions the first city on the continent." (Peyton: Statistical View of Illinois, $\mathrm{P} .4 \mathrm{~s}$ ) 


\section{Influence of the River and Canal upon Popllation and PRODTCTS.}

A comparison of the census returns for 1840 and 1850 brings out clearly the influence of the Illinois and the canal upon the development of the counties with which this report is chiefly concerned. The population of these six river counties increased 154 per cent during the decarle in question. ${ }^{1}$ In the same time the population of the three inland counties bordering them on the east and southeast increased only T4 per cent," and that of the four inland connties touching them on the nortl and northwest, 118 per cent. ${ }^{3}$ The population of the State as a whole increased 78 per cent during these years. Not simply were the river counties growing faster than those on either hand, but within the former the townships near the great waterway were in general most densely settled and gaining most rapidly. While this statement may be made with confirlence, the census reports permit anything like exact comparisons between townships only in Bureau County. There the six southeasternmost townships (See fig. 39) contained about 38 per cent of the population of the county, in spite of the considerable areas withdrawn from occupation by flood-filain and bluff lands, while the remaining 62 per cent were scattered in 19 townships. ${ }^{*}$

The influence of the waterway is shown in another way. In 1850 there were nearly 1,000 more farms in the six river comties than in the adjoining seven inland connties." The average cash value of farm land in the river counties was $\$ 9.78$ per acre; in the four inland counties to the northwest it was $\$ 8.69$; and in the three to the the southeast, $\$ 8.09 .^{\circ}$ Improved land amounted to 15.6 per cent of the area of the six river counties bit only 9.9 per cent of the inland counties. ${ }^{7}$

The differences noted between the river and inland counties disappeared in the next decade when the building of railroads led to the rapid settlement of the great interstream prairies.

\section{Tite Declune of River and Canal Commerce.}

Ralc and extent of decline.-The year 1855 has been taken as marking the close of the period of steamboat supremacy in the trade of Illinois Valley (p.91). The following years witnessed an extraordinary decline in river trade. By 1870 only four steamboats, a pitiful remnant of the great fleet of the late forties, ran regularly between St. Louis and Peoria, and but one of these four extended its trips to LaSalle.

${ }^{1}$ lllinois Blue Book, 1900, Tables, pp. 287-284.

2liem.

Irleni.

4 The census does not give the population of any if the six southeastern townsbips, but fortunately does give that of all the others with a single exception. The above comparison is oniy approximately correct, since it ignores the missing township and credits the six in the southeast with the difference between the total pomiation of the county and that of the eighteen townships reported. (Seventh Census, pp. 703-704.)

s Compendium Seventh Census, Tables, pp. $220-229$.

${ }^{6}$ Seventh Census, pp. 728-729.

7 Idem.

s Ballance: History of Peoria, p. 159. 
Only 7 per cent of the units of freight received at Peoria in 1875 came by the river. ${ }^{1}$ Four years later Peoria received about 40,000 tons of freight by river; this was but a little over 5 per cent of the total amount received." The next year (1880) only two steamboats made regular trips between Peoria and St. Louis. ${ }^{3}$ A writer of the eighties thought it unlikely that water transportation would again be a necessity for years to come. ${ }^{4}$

A similar decrease nccurrerl in the trade of the Illinois and Michigan Canal. It was describerl within nine years of its completion (1857) as an "old fogy institution." "The tolls increased, however, with much variation from year to year, until the middle sixties, and its tonnage until the early eighties (figs. 41 and 42 ) ; after that its business rapidly diminished and has now practically ceased.

Causes of decline of acater trade.-This decline in water traffic was brought about primarily by the competition of the railroads and the shallowness, during many summers, of Illinois River. Various other factors contributed to the triumph of the railroad, however, especially (1) the short season open to navigation; (2) the slowness of water transportation; (3) the lack of coöperation between river and canal service; (4) the limited capacity of the canal; (5) the losses involved in steamboat navigation: and finally (6) unreasonable wharfage charges, and over-competition in river trade. (1) The upper Mississippi and its tributaries were closed by ice four months or more each year." The canal was open on the average only 237 days each year between 1848 and 1900.7 This suspension of traffic was of course very disadvantageous; the railroads were able from the outset to monopolize business for a considerable fraction of the year. (2) The bes: steamboats on the llinois required 20 to 30 hours for the trip from Peru to St. Louis. ${ }^{8}$ The canal boats depended upon animal towage which meant slow, tedious travel, and usually involved delays in the harbor at Chicago and La salle, while waiting for steam vessels to tow them. ${ }^{9}$ The canal accordingly lost its entire passenger business when the Chicago, Rock Island. and Pacific Railroad opened parallel to it in 1853 . The precedins year travel on the canal had been equivalent to 25,966 passengers through its entire length. ${ }^{10}$ The midule Illinois kiver also lost much of its passenger trade following the opening of the railroad from Peoria to Bureau in 1854 (fig. 44). Furthermore, the superior speed of the railroad secured it the transportation of all perisliable and highly manufactured articles. The waterway could only hope to compete in the movement of the heavy, bulky, and non-perishable

1 Sixth Annual Report of Trale aml Commeree of Peoria, on. 52.53.

Pould's Peoria birectory, 1m,0-1, p. 1.

${ }^{3}$ History of Peoria County, 13. 524.

* Gould: History of River Xavigation, $\mathrm{p}, 745$.

5 Chicago Magazine, 7.1 , p. 3.9.

${ }^{6}$ Hall: The West; Its Commerce and Navigation, pp. 96-97.

T Annual Report Canal Commissioners, 1902, †. 31 .

8 Curtiss: Western Portraiture, p. 76; Ellett Summer Rambles in the West, pp. 234.235.

As late as 1576 only twenty-two steam canal boats were in use. Annual Report Canal Commissioners, $1876,1 \%$. 5-6.

10 Annual Report of Board of Canal Trustees, 1853, p. 9. 


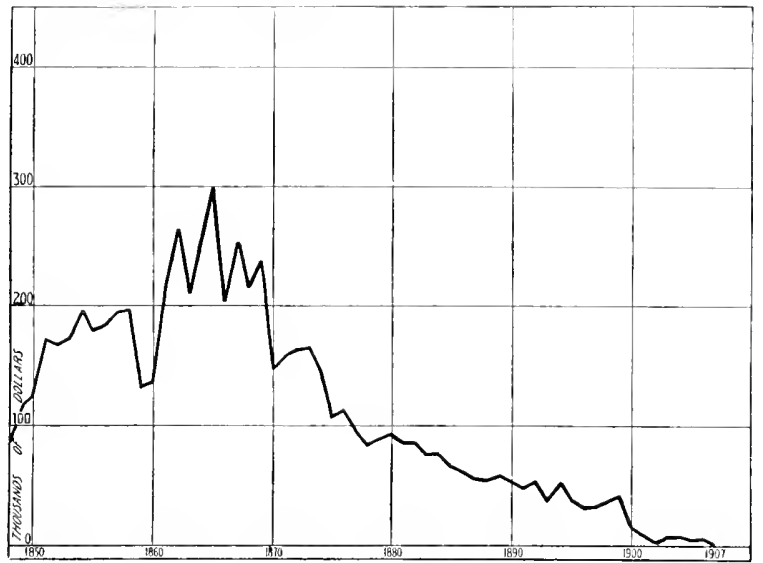

Fki. 41. Graph showing tolls collected by Illinois and Michigan Canal from 1848 to 1907.

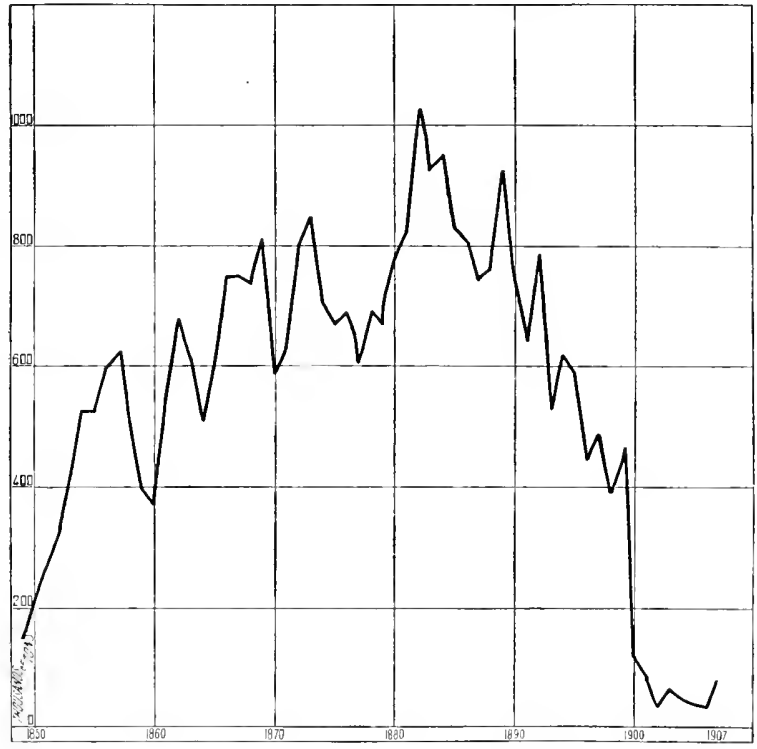

FlG. 42. Graph showing tons transported on Illinois and Michigan Canal from 1849 to 1907. 
commodities. (3) Through business on the waterway was inhibited for the want of a line of steambots on the river running in connection with the packets on the canal. Boats plying between St. Louis and Peru had no regular days of starting. The need of remedying this defect was promptly pointed out, ${ }^{1}$ but a number of years appear to have elapser before it was accomplished. (4) The canal could not accommolate boats of more than + feet 8 inches lraft. carrying a maximum load of about 150 tons. Even this was not possible when the water supply was deficient. (5) Losses were heavy in steamboat navistion from hoilers bursting, machinery breaking, and from other causes. Boats were destroyed not infrequently, and the usual insurance rate on steamboats was from 10 to 12 per cent per annum. ${ }^{2}$ (6) The facility with which boats could be huilt was said to have led to over-competition in the river trade, and wharfage extortions and discriminations were complainerl of at times." It is difficult to julge of the importance of these charges.

The canal officials repeatedly declared the greatest cause for the decline of water traffic to be the shallowness of Illinois River. It will be remembered that the Illinois is an aggrading river that is attempting, through deposition, to form a channel suited to the small volume of water which it has had since it ceased to be the outlet of Lake Chicago. Bars formed, ${ }^{*}$ especially off the mouths of tributaries, upon which at times there was not more than 20 inches of water. This was the case. for example, from the middle of June until November in 1856 when, in consequence, navigation on the river was virtually suspender for nearly six montlos." The lowest water appears to have been reported in 1867 , when there was only 16 to 18 inches on many of the bars. ${ }^{6}$ Again steambots cottl ascend to Peoria or Henry, but were prevented by low water from going farther." At such times traffic on the navigable portion of the river was forced to move to the soutls. ${ }^{8}$ Such difficulties from low water, furthermore, were of frequent occurrence. The river was almost closed to steamboats in $18+1^{\circ}$ and in $18+5 .^{10}$ The officials of the canal complained of loss of business becattse of low water in $1851,1852,1853,185+, 1856,{ }^{11}$ and frequently thereafter. On the other hand, the very satisfactory returns of the year 1865 in comparison to the immediately preceling years (fig. 41 ), were attributed almost entirely to the unusually high water in the Illinois throughout the season of navigation. ${ }^{12}$ In $185+$ the canal commissioners wrote: "It is not the competition by railroad that the canal has to fear; it is the want at times of sufficient water in Illinois River. With that avenue available for boats drawing $t$ feet of water for the eight or nine months

1 Chicago brily lemocrat, Sovember 24, 1545.

2wuld: llisting it River Navigation, pp. sol, 584.

silem.

+ Inmual Report Canal Commissionera, 1476, pp. 13-14: 1590, p. 33.

Inumal Repurt of Board of Cinal Trustees, 1556, p. 83.

"Flang: The Far West, r. 1, p. 110; Annual Report of Board of Canal Trustees, 1852, pp $97,167.165$.

Chica Daily lwmocrat, December 4, 1848 .

"Niles Register, V. 62, p. Er.

We Bow's Reriew, V. l, p. 1th.

11 Amnual Report of Buard of Canal Commissioners, 1851, pF. 11.12; 1652, pp. 97, 167-168; $15.3, \mathrm{p}, \mathrm{o} ; 18.54, \mathrm{p}, 12 ; 1,56, \mathrm{p} . \mathrm{s} 3$

12. 1 dem, 1 stis, p. 10. 
of the year in which the canal is available, there would be nothing further that the friends of the canal would have to ask; but so long as Illinois River remains in its present condition, unimproved, either by the State or the United States, so long will the canal lie idle comparatively one-half of its season of navigation."' Again in 1876 the canal commissioners declared that "the large through lumber and grain trade that formerly passed over this route has nearly all been diverted into other channels by reason of low water. and the formation of bars in the Illinois during the past few years."

Because of the ecomomic disadvantages noted above, the river and canal were totally unable to meet the competition of the railroads. In the discussion of the other causes for the decline of the once great waterway, it was seen that the railroad secured not simply the passenger

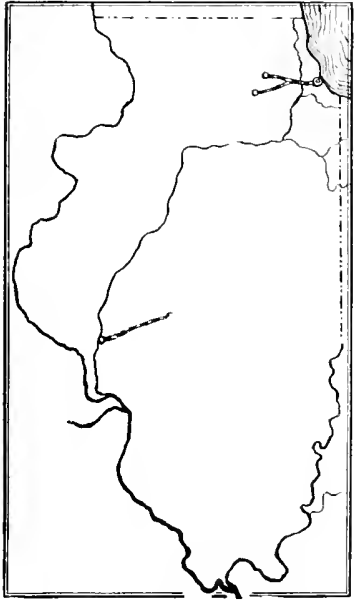

Fra. 43. Map shming railmads of Illinois iII 1850 .

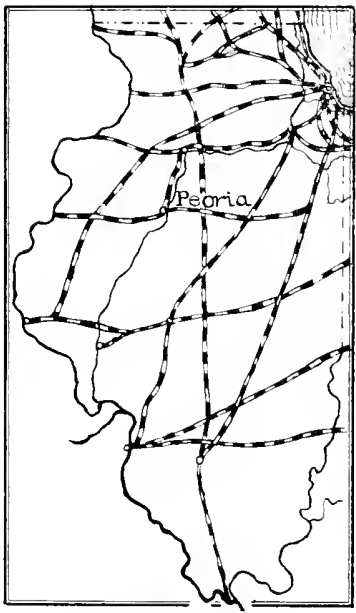

FIt: 44. Jlar ahowing railrouls of lilinois in $10(0)$.

trade and the traffic in perishable and highty manufactured articles, which passeci to it logically, but finally also the trade in lumber and grain, which because of their weight and bulk and its lower rates, the water course might have been expected to retain. In a worl, the history of the later transportation lines upon the Illinois is a record of the

1 Anumal liepolt Canal Commissioner, 15j4. F. 11.

"Ilem, 1-iti, pp. 13-14.

Impressed with its very gentle current a consequence of thr fm grade developer by the Gutlet river, and with the general absence of the snags so charateristic of llississippi and Missouri rivers, earlier writers described the lllinois as the easiest river to navigate in the country, especially in going np-stream. Thwaites: Early Westeru Travels, Y. 9. 1\%. 190; Western Monthly Sragazine, $\mathfrak{\gamma}, 5$, p. 336 ; Publieation No. 5 of the Historical Library of illinois, p. 164; Peck: Guide for Emigrants, p. 330. 
triumph of the locomotive over the steamboat. The famous "Five Day" Line" of steamboats, organized in 1852 to run between St. Louis and LaSalle, did a thriving business until the railroad appeared, but a few vears of railroad competition destroyed it. ${ }^{1}$ The Illinois River Packet Company appeared in the field in 1858 and made a vigorous effort to meet the competition of the railroad, but failed and sold its hoats to a new organization which, in about two years, was in turn forced to confess defeat. ${ }^{2}$ The Naples Packet Line conducted a successful river trade for a longer time, but only because it was run in connection with the railroad extending from Springfield to Illinois River at Naples (fig. 43). This was for a time the only route from the Sangamon country to St. Louis except by stage, and was therefore very popular. ${ }^{3}$

The railroad was credited by some with the conquest of the Illinois and Michigan Canal as early as 1857.* Reading the yearly reports of the canal officials, however, one is impressed with their conviction that the fundamental cause for the eclipse of the waterway was the unfavorable condition of the Illinois, and that if the latter were improved, the canal might successfully compete for the transportation of certain classes of freight (pp. 102-103). It is worthy of special note that physiographic processes were held chiefly responsible for the decline of one of the greatest commercial routes in the West.

Although their trade had departed, the river and canal continued to be of tremendous importance to the people of Illinois as regulators of railroad rates (p. 108).

The effect upon the river toans of the passing of the steamboat.Illinois river towns that obtained good railroad connections did not suffer greatly from the decline of river trade. This was especially true of Peoria, which became a great railroad center for the same reasons that it had before been an important road center and which also developed extensive manufacturing interests. It was true to less extent of Pekin. To every other river town within the area considered in the report, the passage of the steamboat was a serious blow, and several suffered an actual decrease in population.

DePue had been the great shipping point for an extensive area west of the river and enjoved a large trade until near the close of the fifties. By that time the back country had important railroad lines (fig. 44), and the farmers ceased to haul grain to the river with its decreasing shipping facilities. The trarle of DePue, except from the immediate vicinity, soon ceaserl, and in 1884 the place was described as a "queer little dilapiclaterl village," many of whose inhabitants depender on the lake for a living, fishing by summer and packing ice for one of the St. Louis breweries by winter."

1 Gould: History of River Navigation, pp. 522-523.

- History of Peoria County, p. 527; Gould: History of River Navigation, pp. 523-524.

3 den, pp. 521-522-523.

* Junt's Merchants' Jagazine, V. 37, p. 376; Chicago Magazine, V. I. P. 389.

5 Typical discussons of the matter may be found in the Annual Reports of the Board of

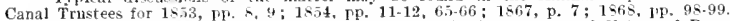
P. 159.

Bradsby: History of Bureau County, F. 436; The Taxpayers and Foters of Burean County, 
Hennepin experienced a decline similar to that of DePue. It had a population of 711 in 1857 , and a large commerce ${ }^{1}$ but having lost its river trade and being without any railroad, each census since 1860 has recorded a decrease in population, that of 1900 being only $523 .{ }^{2}$

The population statistics of Henry tell of a period of rapid growth under the influence of river trade, and of one of relative stagnation following the passing of the steamboat. The substantial growth of the place began in 1844 with the multiplication of steamboats above Peoria. It container 400 people in 1850." During the next six years the population inc reased over four fold, reaching 1,664 in $1856 .^{*}$ Since the loss of its river trade, the town has been essentially at a standstill, having in 1900 only $1,6,37$ inhabitants. ${ }^{5}$ The story is again repeated, in principle, in the case of lacon. In the late fifties this place had nearly 2,000 inlubitants," but it was nearly stationary letween $1860^{\circ}$ and 1870 , and since the latter date it has steadily lost. ${ }^{\top}$ Lacon's railroad service is far less satisfactory than that of Henry, since it is situated at the end of a branch line.

The decay of Spring Bay is particularly striking. In its best days, it is said to have had eight or nine grain warehouses to which practically all the farmers of Woodford County hauled their grain. In the spring eight or nine steamboats might be seen at the levee at a single time loading for the down-river market. The disappearance of the steamboats and the opening of railroads to the east of Spring Bay, running parallel to the river, proved a death blow to the town. Most of the inhabitants moved away, and the last warehouse was destroyed years ago. ${ }^{8}$ Chillicothe has had a happier history. Like the other river towns mentioned, it suffered from the loss of its river grain trade, but it was fortunate in later lecoming a junction point between two important railroads. Its population accordingly increased rapidly between 1880 and 1890 , but it has been nearly stationary since.

\section{Attempts to Impkove THe Navlgatuon of lllinots River}

The improvement of the navigation of the lllinois was urged for many years. Governor Ford caused the first surves of the river to be nade in 1835 , with a view to its improventent. ${ }^{10}$ Steamboat owners in 1848 advocated the improvement of the channel by a system of

1 Ford: Hixtory of Putnam and Marchall Counties, ly. s!t.

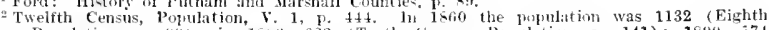

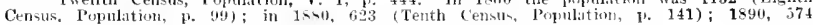
(Twelfth Census, V. 1, p. 124).

${ }^{3}$ seventh Census, p, cxi

t llawes: Illino io state fiazetteer (1858-9), F. 107.

Twelfth Census, Population, V. I, p. 44. The population in 3 k60 was 1800 (Ford: Ilistory of 1'utnam and larkhall Comnties, p. 114); in 1870. 2162 (Ninth Census, Population, p. 116); 1880,1728 (Tenth Census, Population, p. 139); isio, 1i12 (Twelfth Census, V. I, p. 126).

Hawes: Illinois State Gazetteer (1858-9), p. 123.

7 Population 1870, 2105 (Ninth Census, Population, p, 116): 1880, 1811 (Tenth Census,

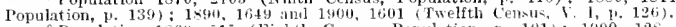

${ }^{8}$ Population 1860,515 (Eighth Cenkus, Population, p, 101); 1900,125 (Twelfth Census, V. I, 1. 133).

Population 1mo0, \$36 (Tenth Census, P'opulation, D, 14ii); 1*40. 1632 and 1900, 1699 (Twelfth Census, V. I, p. 128).

w Brown: brainage Channel and Waterway, b. 260. 
dredging, and in 1852 the ferleral government made its first appropriation for that pupo-e. ${ }^{2}$ The experiences of the year 1853, however, were said to have first forcel the general public to recognize the disagreeable fact that the river requirel human aid." The trustees of the canal yearly urged river improvements, declaring that unless they were undertaken the canal must continue of secondary importance, hoth as a producer of revenue for the state and as a channel for trade, and that if they were male, a steady increase from year to year in the business of the canal might confidently be expected. ${ }^{\ddagger}$ During the Civil IVar the improvenent of navigation between Lake Michigan and the Mississippi was urged as a military measure. A bill introduced with this object early in 1862 failed atter having been before the House for nearly a rear, through the votes of Ohio and Indiana, whose representatives claimed that its nilitary features were altogether subordinate, and that it was really an attempt to benefit a single state commercially at the expense of the whole country." The attitude of Ohio and Indiana probably had a geographic basis, since from their locations these states were rivals of Illinnis for the control of commerce passing between the Great Lakes and the western rivers. In his message of January 5 , 1863, Governor Yates recommended that the General Assembly memoralize Congress in relation to the projected improvement, and maintained that it should be undertaken as a military necessity, as an aid to commercial, manufacturing, and agricultural interests, and because it would serve as a bond of union hetween the different sections of the country, ${ }^{6}$

Aside from dredging to overcome bars, the first improvenent of importance was the Henry lock and dam, built by the State. A committee of the State Legislature had recommended a system of locks and rams as early as $1848,{ }^{\top}$ but the improvenent at Henry was not definitely provided for until 1867. $\mathrm{s}$ The lock was first used in January, 18\%2. The river business of that year was disappointing. nevertheless, the supprosed cause being the unusually low water in the Illinois, and four more locks and dams between Henry and the mouth of the river were uroed." Another lock and dam was later built by the state and federal governments at Copperas Creek, and two others by the latter farther down the river. Experience appears to have shown clearly that the dams and locks have injured rather than aided the navigation of the river. Ther constitute obstructions to the flow of the strean and, by checking its already slow current, cause futher deposition and further choking of the chamel. ${ }^{10}$ The dams have probalily also tended to increase the number and duration of floods, thus helping to prevent the agricultural use of the bottom lands.

\footnotetext{
${ }^{1}$ Chicago Daily lentnerat. Hecember t, lats,

2 Brown: Drainage (hasuel aml Waterway, 1. af 60 .

3 Davidson and stuve: Jistory of lllinuis, p. to 7 .

Characteristic statement - oceur in the Ammal Report of the Board of Canal Trustees, 1855, p. $10 ; 18.57$, p. $9 ; 1866$, ก. 111

Brown: Drainage Chamel and Watemay, H. 231-232.

6 Repots of the General Asembly of lllinois, $140, \mathrm{Y}, 2, \mathrm{pp} .348+349$

Brown: Drainare Chamel and Waterwar, Ip. 260-261.

${ }^{8}$ Idem, p. 266.

Annual Renort of Canjl Commisioners, 1872. pp. 29, 31, 33.

10 Seventeenth Annual Report, U. S. Geological Survey, V. 2, np. $744-745$.
} 
The federal govermment had appropriated over 2 million follars for Illinois River br $1900^{1}$ for survers, dredging, locks and dams. This is but a smail fraction of the suin now demanded for the river (p. 122).

As a result of pronounced agitation for better sanitation in Chicago. the State Legislature authorized a slight enlargement of the Jllinois and Michigan Canal in 1865. The improvement was completed in $1871,{ }^{2}$ but proved of little value commercially.

\section{The Railroads and tiff Settlement of the Great Prairies.}

The great prairies still remained largely unoccupied in 1850 , as a comparison of the woodland and prairie map (fig. 35) with the population map for 1850 (fig. .37) clearly shows. The problems of transportation and of markets still preventerl their occupation. During the decade 1850 to 1860 , however, their conquest was rapidly accomplished. and in the latter year (fig. 38) the frand Prairie had everywhere a population of over six to the square mile, and the great prairies to the north of Illinois River more than 18 per square mile. The population of the State as a whole increased over 100 per cent in the ten years. ${ }^{3}$ This extraordinary change was made possible by the rapid building of railroads. In 1850 Illinois had only 110 miles of railroad ${ }^{+}$(fig. 43); in 1860 it had 2,867 miles ${ }^{5}$ (fig. 44). During the Gecade Illinois built more miles of railroad than any other State, and more than Michigan, Wisconsin, and Iowa combined." The topography of the State made it possible to build railroads rapidly and easily $;^{*}$ in the northern and eastern parts especially, the railroarls were not held to certain predetermined courses by relief, but could be built with equal ease in almost any direction across the flattish surface of the upland prairies.

The railroads supplied lumber to the lome builder on the great prairies. ${ }^{8}$ They brought the farmer much closer to a market, ${ }^{9}$ increased greatly the value of land in the vicinity, ${ }^{10}$ and permitted a rapid growth in agriculture products. ${ }^{11}$ In 1850 lilinois was the fifth wheat state,

\footnotetext{
${ }^{1}$ Raymond: Index to Reports of Chief of Engineers. U, S. Army, Y, 1, 1p. $512,517$.

2 Brown: Dranage Channel and Waterway, pp. 249.2.5.

3 1850, -51.470; 1860, 1,711,951 (1llinois Blue Book, 1905, p. 580).

"Parker: Growtl of llinois and Chicago, p. 13.

5 Idem.

"Illinois Blue Book, 1903, p. 156 .

7 Tanner: Camals and Railroads of the U. S., p. 194
}

Walker: The yississppi Valley, p. 260 ; Ferris: The States and Territories of the Great West, pr. 208.209 .

An interesting entinate of the influence of railroals upon the transportation liroblem appealed in De Bow's Review, 5 . 14, 1 p. 79-80. 1t was thought that on the average wagon road the cont of transportation was 1 - cents per ton per nile, and wheat was assumed to be worth \$1.50 a lushel and com 7.5 rent. Thirty-the hushels of purb were taken to equal a ton. In that case the cost of tramsorting a ton of wheat busme equivalert to its value at 334 miles. corn at 170 miles, 1n other worls, the grain would be worthless at the dist:mees mentioned from market. Railroal transportation, it was estimated, rost only one-tenth as much as that by wagon. Railroads, therefore, extended the economic limit for the transortation of wheat and corn respectively to 3,300 and 1.760 miles. At Chicano, bowever, 60 cents a hushel for wheat and 26 cents for shelled corn was a sond price in the years just freceding the aprearnoe of the railroad (1'rairie Farmer, Y. 6, D. 296; Y. 7, p. 264 ); often the price was much lower (p. 83). At these prices corn would be worthless by wagon transportation at 57 miles from the lake port and wheat at 132 miles, while roilroals would extend the resrective limits to 570 and 1.320 miles.

10 Davidsom and Stuve: History of lllinois, F. 572 ; 1) Bow's Reriew, V. 14, p. 80.

1 Eighth Census, Agriculture, jr, clxy. elxii. 
with $9,414,575$ bushels; in 1860 , it was first with $23,837,023$ bushels : ${ }^{1}$ it was the third corn state in 1850 , with 57.646 .984 bushels; it was an emphatic first in 1860 . with $115,174,777$ bushels. $^{2}$

Except along the edges, little of the great prairie tracts in the middle valley counties was occupier in $1850 .^{3}$ In the decade 1850 to 1860 , the aggregate poptlation of the six counties increased $12+$ per cent. ${ }^{4}$ The area of the improved land increased 213 per cent, ${ }^{5}$ and the grain production 165 per cent in the same time. ${ }^{6}$ The relative increase in population in the prairie townships back from the river was much greater. but cannot lye staterl exactly outside of Bureau County.' There the townships of W'alnut and Chio ( fig. 39), already described as largely unoccupied in 1850 , gained respectively 1.025 per cent and 489 per cent. $^{8}$ The adjacent inland counties whose growth before 1850 had been retarded ly their distance from the river filled rapidly. The four on the north and northwest increased 190 per cent cluring the decade, while the three to the southeast gained 224 per cent. ${ }^{9}$

At the same time that the railroads were opening up the great prairies, improved farming machinery was facilitating their agricultural development. Drills, mowing machines, reapers, threshing machines, and the like were coming into general use.

\section{Influence of Illinois River and the Canal on Railroan Rates,}

The importance of Illinois River and the canal did not encl with the loss of their carrying trade. Indeed, their greatest service to thate has perhaps been their influence in securing low railroad freight rates. The competing railroats are forcel during the season of navigation to establish rates near enough to the water rates so that shippers will prefer land transportation. This has saved the people living along the fine of the river and canal many millions of dollars. ${ }^{10}$ The value of the canal and river as freight regulators may best be shown ly a few specific illustrations from various years.

(1) Corn was shipped by water in 1870 from Henry to Chicago, 130 miles, for 5 cents per hishel, wheat at 6 cents. The rate on the Chicago, Rock Island, ansl Pacific Railroad during navigation was 7.16 cents per bushel for corn and 10 cents for wheat; during the winter season the rate was 9.3, cents for corn and 12.40 cents

Eishth Censis. Agriculture, p, ixix.

lilem, y. xlvii.

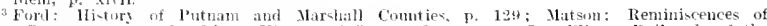

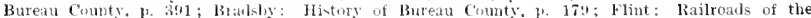
United states, ne $33+i$

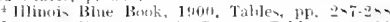

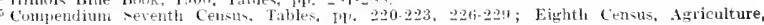
Tables,

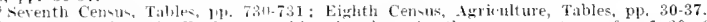

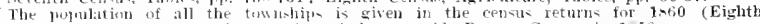

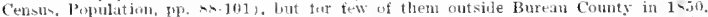

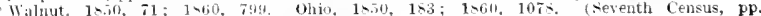
703-704; Eighth Census. Pupulation, pr. Ex-69.)

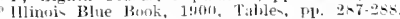

1" It was estimated thit in 1 squ the eichteen comnties bordering the river and canal north of

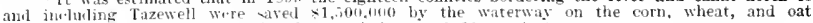
crops alone. (Annual Re!mit Cinal (immissioners, 1901, p, to.) 
for wheat. On the railroads not subject to water competition the rates were from 11 to $14 \mathrm{r} / 2$ cents per bushel for corn, and 15 to 18 cents for wheat for the same distance. ${ }^{1}$

(2) The competing railroads established notably lower rates during the navigation season than in winter, when ther were in the position of a monopoly. Thus in January, 1875, the railroad rate on flour from Peoria to New York was 90 cents a barrel. It fell by stages to 50 cents in August, but rose again to $\$ 1.00$ in the following December. The corresponding variations in the rates on grain, meats, etc., were of similar magnitude. ${ }^{2}$

(3) The Chicago, Rock Island, and Pacific Railroad has charged 15 cents per 100 pounds for freight from Tiskilwa (a few miles west of Bureau and besond the reach of water competition) to Chicago, 122 miles, when it charged only 8 cents from Henry to Chicago, 130 niles. ${ }^{3}$

(4) In 1901 , the railroad freight rates to Clicago in northern Illinois were lowest along the Illinois and the canal, and higher with increasing distance from the waterway regardless of the distance from Chicago. ${ }^{+}$Yet in this year the canal itself had virtually ceased to carry freight (fig. 42).

\section{The Developuent of Manufactures.}

There are two more or less distinct periods in the development of manufactures in the area, the first characterized by small estalijilments at many places, the second marked by large establishments at a few favored places. In both periods the nore important manufactures belong to two classes: (1) Commodities demanded in the region where it was expensive and at times impossible to bring from a distance, and (2) commodities for the making of which the surplus products of the region afforded the raw material and which could be transported to a market more econonically in the manufactured than in the crude state.

\section{EARLY INDUSTRIES.}

Slanghtering and meat packing.-The important manufactures of the first period were the making of flour and feed. lumbering and especially slaughtering and meat packing. The making of whiskey also became an important industry before 1850 . The raising of swine received attention early in lilinois Valley. The business was peculiarly suited to frontier conflitions. Much wooded bluff and ravine land was fit for little else. Corn, the learling crop, was bulky and heavy, and therefore difficult to tran-port to the ristant markets. It was accordingly found advantageons to use corn in fattening swine, which could walk to market or. when lilled, found a market at the down-

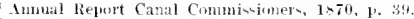

sixth innual Rejurt of the Trale and Commice of peoria. 1'. 33

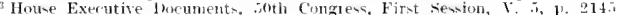

* Railroad late Map, opp. p. on of Annual Reprit Canal Comminginers, 1901.
} 
river cities, particularly New Orleans. At first all the slaughtcring was done by farmers in the winter, who, after supplying their own wants, sent the surplus down the Illinois. Nearly 140,000 pounds of pork and 10,000 pounds of lard were shipped by river from Peoria County in February, 1\$35. ${ }^{1}$ Later the industry was established in the towns. It was leegun at Peoria in $1837,{ }^{2}$ and soon all the river towns participated actively. The few inland towns do not appear to have ensagerl to any extent in the business, owing to rifficulties of transportation. Slanghtering was still done by farmers who sold their suplus meat to the dealers in the towns, ly whon it was cured for the market. The pacling season was linited to the winter months." The importance of the industry along the Illinois in comparison to other places is suggested by the fact that as many hogs were killed at Lacon in the season of $184^{\circ}-1850$, as at (hicago; Peoria hilled nearly twice as many, and Pekin more than double the number." The next season Peoria led the towns on the midlle Illinois with 30,000 hogs, ${ }^{6}$ while Chicago killed only about 20,000. ${ }^{\top}$. From that time, however, the business increased rapidly in Chicago, and by 1861-1862 it was the leading slanghtering and packing center in the United States, killing over twenty times as

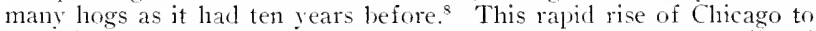
preeminence as a packing center was due largely to the great railroad mileage that, beginning in the decade $1850-1860$ (figs. 43 and 44 ). became tributary to the city. ${ }^{9}$ Greater economy in manufacture was possible in a small number of large establishments. Accordingly the development of rail road transportation contributed to the decline of the industry in the towns on middle Illinois River, except in the case of Peoria.

Manufacture of flour.-The early manufacture of flour beyond the needs of local consumption probably has its explanation in the desire to reduce the surplus grain to the smallest possible compass in order to transport it profitably to the distant markets. The same considerations had led to the rather extensive manufacture of flour still eatlier in Ohio. ${ }^{10}$ One of the first flouring mills in that part of the State was built in 1830 on Kickapoo Creek, near Peoria. The product, beyond that required in the vicinity, was sent on large flat boats to New Orleans, where it was sold from $\$ 1.37$ to $\$ 1.50$ a barrel. ${ }^{11}$ Peoria had four mills in 1850, which that year exported nearly 34,000 barrels of flour valued at about $\$ 1,52,000 .^{12}$

\footnotetext{
Illinotis in $1837, \mathrm{P}, 96$.

${ }^{2}$ Hintury of Peoria Coming, I. it 3 . p. 410 .

Princetun. howerer, is reditel with killing 3,700 hogs in $1049-50$; Western Jomral, Y. 3 ,

¿Perria appears to have firut tried the experiment of summer packing in 1872. (Third Aunal Report to the Jestia Boaril of Trade. p. 21.)

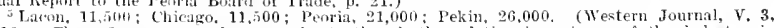
p. 410.) Thene figmres are only apmroximate though the relative importance of the industry in the several tum $m$ is correctly stated. simmewhat different figures are grien for example, in Western . Joumil, Y. 6, F. 191 .

it Western . Jumal, V. 6, n. 191

; Twelfth C'ensus, $Y, 0,11, \pm 14$.

8 De Buw's Reriew, heconl tories, Y. 4, P. 116; Twelfth Census, V. 9, p. 413. Chicago is sail to have conmenrel billing catlle in 1832 (Parker: Growth of Iilinois and Chicago, p. 11), and seems to have ley in the clamrlitering and packing of cattle by the early fifties. (Curtiss: Western lontraiture, 12. 1 ; I te Buw's Review, Second Series, 1. 4, p. 116.)

${ }_{9}^{9}$ Twelfth Cencus, Y. $9, \mathrm{n}, 414$

10 Eighth Cemsu. loricultule, 1. cxis, exxx

11 Gould's Pestia loirestory, 1ssole 1, n. 3.

Idem; llintury of Peuria County, D. 452.
} 
Mamnacure of athisky-The problem of marketing the surplus corn was solved in part by the manufacture of whiskey, which carried the crop in small bulk with large value. Pekin had two steam distilleries in $1837:{ }^{1}$ ['eoria built one that proved a great success in 1844." Three years later Peoria exporter 4,500 barreis of whiskey, ${ }^{3}$ and 5.685 barrels in 1850 , worth nearly $\$ 5 \%, 000 .{ }^{*}$

As already indicated, the development of manufactures in the region was characterized in the earlic years by relatively small establishments in all of the towns, at least all situated upon the river. Pekin illustrated typically the manufacturing interests of these places. In 1837, when its population was only about 800 , it had two slaughtering and packing houses, a steam flouring mill, a steam saw mill, and two steam distilleries. ${ }^{5}$ The census of 1860 shows that manufacturing interests were still widely distriluted. ${ }^{6}$ The concentration then in progress continued rapidly, however, until today manufacturing within the area is confiner almost entirely to Peoria and Pelin.

\section{TIIE GREAT PEORIA INDUSTRIES}

General advantages of Peoria as a manufacturing center.-The extensive development of manufactures in Peoria was favored by (1) the location of the city. (2) its transportation facilities, and (3) an abundant supply of cheap coal. (1) Peoria is centrally located with reference to Illinois Valley and to the State, in the midst of an agriculitural area of unsurpassed fertility. (2) The location and commercial importance of Peoria insured it good railroad connections. It hat three railroads in 1860 (fig. 44). The number har grown to ten in 1875, with nearly 100 freight trains daily shortly after. ${ }^{8}$ Twelve railroads now focus on the city ${ }^{9}$ trom all directions, like the spokes of a wheel. The competition of the railroarls, and particularly the wholesome influence of the Illinois have secured Peoria low freight rates. These transportation conditions have facilitated both the collection of the surplus grain of the surrounding area, and the distribution of manufactured commodities. (3) One of the greatest advantages Peoria has possessed in the development of its manufactures has been cheap coal. During the period of the establishment of the great industries it was brought to the city in wagons and sold at 7 to 8 cents a bushel, or at $\$ 1.50$ to $\$ 2.00$ a tonn ${ }^{10}$ Indeed, it was claimed that coal could be mined

${ }^{1}$ Illinois in $1837, \mathrm{p}, 125$.

2 Ballance: Ilistory of Peoria, pp, 13.j-136.

${ }^{3}$ Western Jomrnal, V. 1, p. 113.

* Drown: liecord and Historical View of Peoria, p. 144.

stlinois in 1537, p. 125.

"The manufactures of Putnan Conty were reported at $\$ 38,7.59$; those of Burean at $\$ 125,653$; Marshall, \$545,700: Woolford, \$\$294,234: Peoria, \$4,930.746; Tazewell, \$527,65.5. (Eighth Census Manufactures pp. 84, 109.)

Sixth Annual Report of Trade and Commerce of Peoria, p. 53.

8 History of Peoria Countr, p. 30.

- Thirty-sixth Annual Report of Trade and Commerce of Peoria, pp. 56-5T.

10 Drown: Record and Historical Yiew of Peoria, p. 14t; Hunt's llerchants' Magazine, V. 41, p. 696; Third Annual Report to the Penria Board of Trade, p. 10; Fould: Peoria Directory, 1880-1, p. 7. 


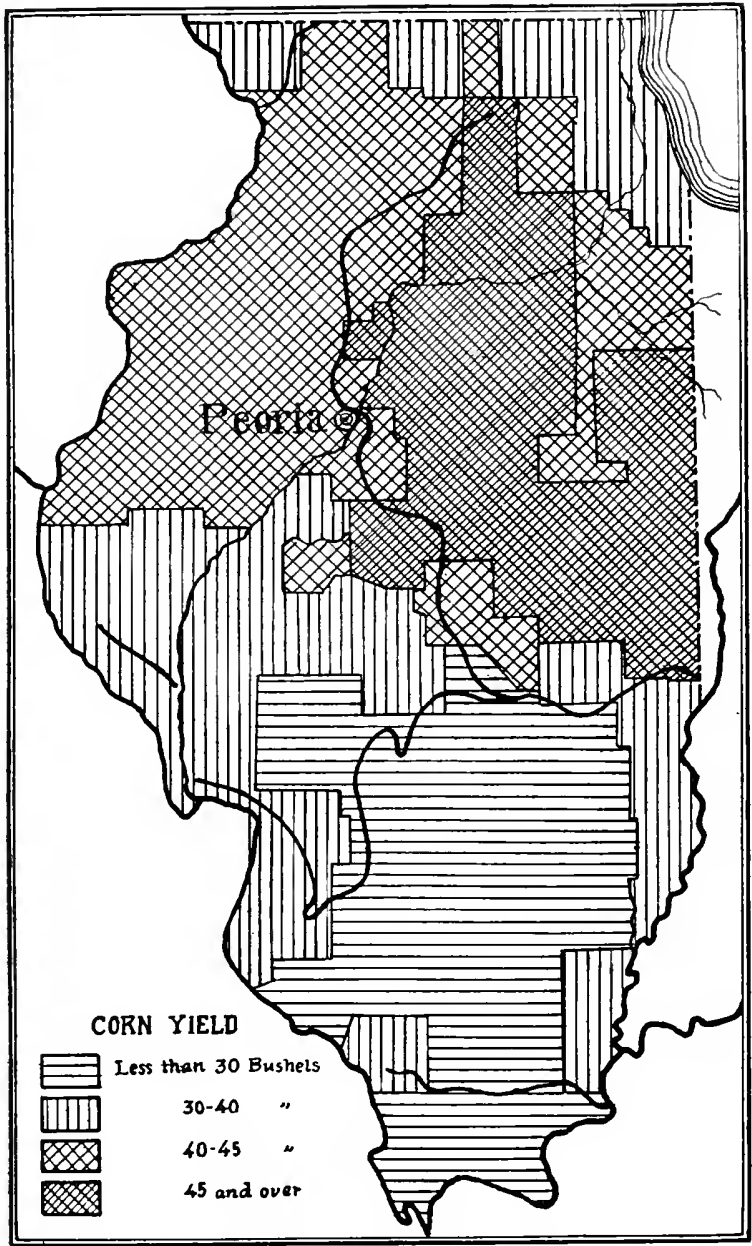

FIG. 45. Hap showing the yield of corn per acre throughout Illinois. 


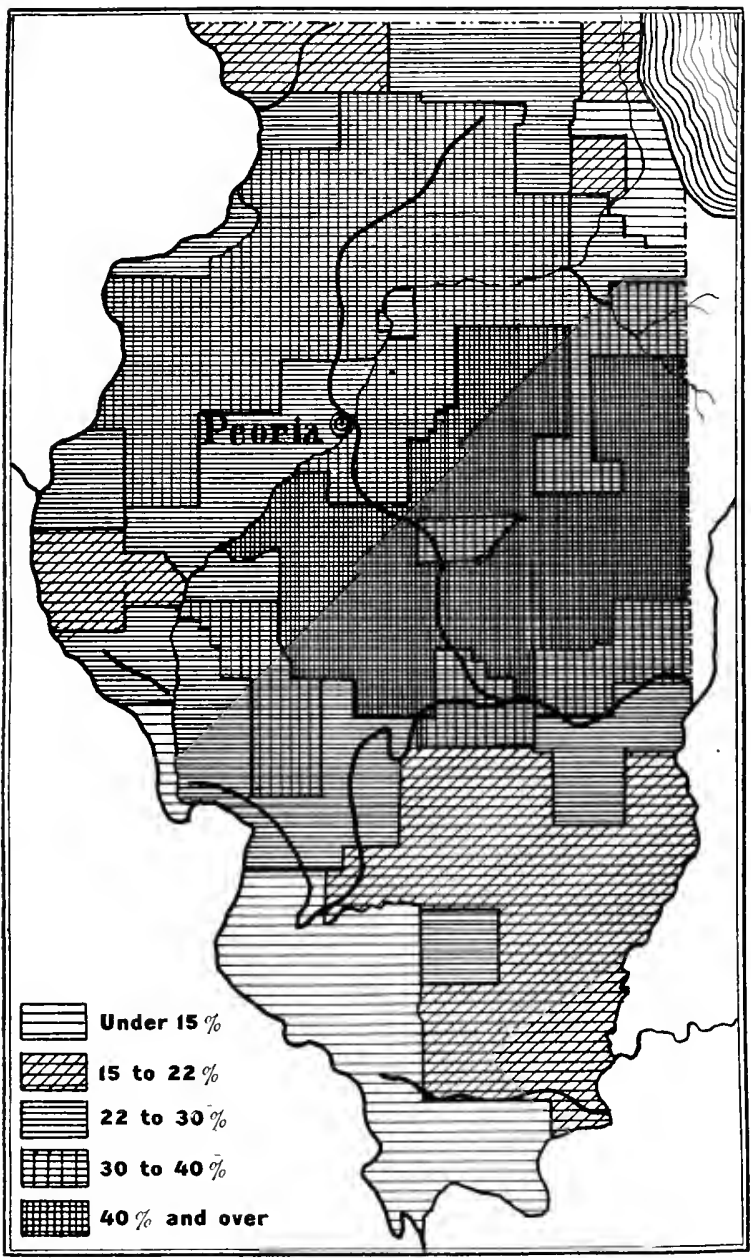

F1G, 46. Map showing the percentage of the total area which is devoted to corn culture throughout Illinois. 
and marketed cheaper at P'eoria than at any other place in the State. It was used near Peoria from an early date. ${ }^{2}$ As the coal occurs in essentially horizontal beds, which outcrop on the siles of various ravines, no special skill or knowledge was required to obtain it, and the simplest methods of drift-mining were followed.

Corn products. - The distinguisling manufacturing industry of Peoria has long been the distilling business, and the glucose industry is now second in importance." For the manufacture of its corn prorlucts, Peoria has, in addition to the general advantages noted above, a central location in the corn helt of the State. Figure 45 shows the corn yield per acre throughout the State, and indicates clearly the arlvantageous position of Teoria in relation to the areas that prodice oser fo buslocts to the acre. The control of the corn yield by the several drift areas, whose borders are indicated ly the irregular, heavy lines is very striking. Figure 46 shows the percentage of the total area which is devoted to corn culture throughout the State, and emphasizes the favorable location of Peoria with reference to the areas of higher specialization. some of the lines bordering the drift areas have less importance than on the preceding map, while others are of equal significance. The inportance of Pcoria's favorable position on the corn maps will be appreciated when it is stated that the distilleries of the Peoria Internal Revonue District use $5,809,170$ bushels of corn in the year ending June $30,1906 .^{5}$ This means 464 acres of corn each week day of the year (counting 40 bushels to the acre.)

\footnotetext{
1 History of Peoria County, p. 266.

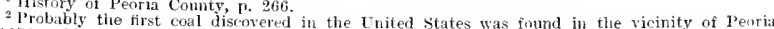
in 1673. The soldiers stationed at Ft. Clarli found coal of good qualif on the banks of Kirkapw Creek abnut a mile alwe its mouth, which they ured for fuel. iBeck: Gazetteer of IIJinois and Missouri, p. 14f.) 1llinois Valley coal was describes in 1823 as very abundant, and valuable becanse of the scarcity of timher. (1dem, p. 18.) In 1837 it was hanled by wason one to three miles into peoria where it was generally ued for fuel and sold for 12 cests a bosliel. (1)ilinois in $1837, \mathrm{p}, 96$. )

3 C'ensus Bulletin 52 , p. 29.

t The areat of heaviest yield (4.5 buthels aul over per acre) coincides esputially with the Wisconsin dritt, the boumlary of which is indicated on the map by the heary lime which erosces Illinois River at Peoria. Sive in the northeast, the soils of the Wisconsin irift are dominantly dark brown silt loams, and over large areas in the earlier Wisconsin area, black clay Ioams (University of lllinois Igricultural Experiment Station, Bulletin 123, pp, 220, 233.) These soils are in general ris in nitrogen and phosphorus (Idem, pp. 222, 233) and are of great fertility. The former type particularly has treat cupacity to aborl and hul water from beavy rajns, later delivering it as needed to growine crops (ldem, p. 322 ). The black color of the seconil type is lne to the thigh content of humus, a monequence of the very flat topography of the infer-morainic tracts where it necurs, and the resulting poor drainage. The imperfect natural drainaze, however, has required extensive ditching and tiling. The lower yield in the north. eastern part of the Wisconsin area near Lake Nichism is due to the influence of Chirago and its suburbs, ant to the fact that the broad morainic tracts of this section (F1s. 20 ) are characterized by a yellow-gray silt loam soil mud porrer in phosthorus and humbs and less fertile than the soils to the southwest. (1/em, pp. 238-239.)

The area between Illinois River and the irregular heavy line extending from its mouth to the border of the Wisconsin trift is the area of midlle Illinoian glaciation, while to the south of the irregular line the drift is lower lllinoian. The former unally has a brown silt loam of the general type deseribed above, although beause of its rreater age and the befter development of drainage lines, it ss often somewhat ponrer in nitrogen and phosplorus (Idem, 1. 222). It yields in general mose than 30 bushols of corn to the acre. The lower lllinoian area has a gray silt lowm soil over laros areas (liem, p. 210). It montaius lesa than one-half as muth witrogen and fliosplontus as the black cluy loams of the early Wisconsin area (1tlem, 1. 197), and is of relatively inferior quality, profucing less than 30 bishels of eurn per acre. The greater yicle in the exitern part of this area is probably due to the bottom lands of the Wabash. Vorth of lllinoju River the upper Illinoian drift usually has a relatively fertile hown silt loam suj] of the type already described (1dem, pp. 220, 222). The principal upland seril of the neighboring lown drift is a sandy lom (ldem, p. 222), The combined area produces 40 to 4.5 bushels of con per ncre, except in the broken, hilly land of the sonthern part. The heary lines crossing the southrm end of the state, the lower part of the peninsula between lllinois and Mlisisippi rivers, and the northwestern comer of the State, separate glaciated from unglaciated areas. The latter are in general relatively infertile.

5 Annual Report Commissioner of lnternal Revenie, 1906, p. 62.
} 
The distilling industry in Peoria had become the leadling manufactur. ing interest of the city by $185^{\circ}-1860 .^{1}$ In $186+$ there was no less than 12 distilleries within the city, and several others in the vicinity. These 12 distilleries produced over 38,000 gallons of whiskey daily, and used 10,500 bushels of grain and 5.250 lushels of coal. ${ }^{2}$ The inclustry was prostrated for a time in consequence of the passage of the internal revenue law of 1864, and the growing dependence of the city unon it was painfully illustrated." The business revived with the reduction of the tax, and in 1870 there were eight distilleries again in operation." From then on the industry grew rapidly." There were 11 distilleries in 1879 ," and the output was over three times as great as that of 1870. .

l'eoria had lecome the leading distilling city of the United States.

The United States in 1900 produced distilled liquors to the value of $\$ 63,496,208$. Of this Peoria produced \$26,792,35t, learling its nearest competitor by over 10 million clollars. ${ }^{8}$ In 1005 , the Peoria product reached $\$+2,170,815$. This formed $7 \% .9$ per cent of the total for the industry in the State, and represented an increase in value of 57.4 per cent in five years." It formed, furthermore, more than 69 per cent of the product of all Peoria industries. The internal revenue collections on distilled spirits in the Peoria district amounted to over 33 million dollars for the year ending June 30, 1906. This was over 63 per cent of the total internal revenute taxes paid by the State, and greatly in excess of those collected in any other 65 collection districts of the Uniterl States." The fact of chief importance here is that Peoria was led to specialize to such an extent in the liquor industry, and attained learlership in the United States in this particular business, because of the geograplic conditions discussed above.

The manufacture of glucose, begun in the United States about 1870 , is now practically confined to Illinois. ${ }^{11}$ Peoria built its first factory in $1879,{ }^{12}$ and the following year used 7,500 bushels of corn daily in the making of glucose and grape sugar. ${ }^{1.2}$ As already indicated the industry has come to hold second rank among the manufacturing interests of Peoria, but definite statistics regarling it are not available. ${ }^{1 *}$ Starch has been manufactured on a fatrly large scale in the past in Peoria, but is not mentioned in the 1905 census list of industries for the city. ${ }^{13}$

${ }^{1}$ History of Peolia Cunty, 1. 553 ; Eighth Census, Manufactures, 1. 101.

2 Ballance: Ilistory of ['eoria, pp. 136-137.

Jdem, Pp. 13h-140; Coull: Peoria Directory, 1s80.1, pp. 5.6.

* Ciould: Loc, cit.

"Porter: The Viest in 1880, p. 538.

History of Pentia Comnty, p. 235 ; Gould: loc. cit.

"Porter: loc. cit.

8 Twelfth Census, i. S, p. 1069.

${ }^{9}$ Census Bulletin s:, 1. 29 .

10 Annual Report Commissioner of Internal Revente, 1906, pp. 1-2, $130-131$.

11 Srecial Cersus Report on Manufactures, 150, Part 1, p. cxxrviij.

12 Histoly of Peoriti County, P. 5.52 .

${ }^{13}$ Gould: Peoria Directory, 1850-1, p. 6.

14 Census Bulletin $52,0.29$.

13 Hunt's Iterchants" Mligazine, I. 41, pp. 690-691; Ballance: History of Peoria, p. 146; History of l'eoria County, pp. $554-5.53$.

${ }_{16}$ Census Bulletin 52 , pr. $48-49$. 
Agricultural implements-Next to the making of the two great corn products, distilled liquors and glucose, the manufacturing of agricultural implements is the leading industry of Peoria. Its importance is due chiefly to the great demand for implements existing in the agricultural region surrounding the city. The industry always tends to establish itself near its chief marliet, because of the high freight rates charged on its products, many of which occupy much car space. Peoria is also favorally situated with reference to the iron manufacturing centers near the end of Lake Michigan, and, by way of the lake, with reference to the hardwond forests of IVisconsin and Michigan. In 1890, the agricultural implements made in Peoria were valued at $\$ 517,611$ and constituted only 0.9 per cent of the industries of the city; in 1900 , the prorluct was valued at $\$ 2,372,329$, making 4.9 per cent of all industries. ${ }^{2}$ In the latter year, Peoria ranked fifth among the cities of the United States in the industry. ${ }^{3}$ The principal implements made, reflect the dominant interests of the tributary agricultural area. They are corn planters, grain drills and sowers, listers, cultivators, equalizers, harrows, plows, stock cutters, and harvesters, besides many miscellaneous implements. ${ }^{*}$ In earlier days, the country about Peoria depended upon Pittsburg for its few agricultural implements. ${ }^{5}$ The industry was inaugurated at Teoria with the manufacture of plows in 1843 and proved very successful. Before 1859 the city was making 10,000 plows per year. The original plant mate 3,000 plows in $186^{\circ}$ and about 1,200 cultivators. The second plant established made 20,000 plows in 1870 . Peoria implements found a market westward to the Pacific. ${ }^{6}$

Slaughtering and meat packing.--The fourth industry in importance in Peoria is that of slaughtering and meat packing. Its early developments in the region and its decline outside of Peoria have already been discussed (pp.109-110). Its importance continued in Peoria because of its good railmad facilities and because of the distilleries. It was found profitable to use the refuse of the grain after its use in the manufacture of whiskey, in fattening cattle and swine. In 1905, the value of the products was $\$ 1,480,398 .^{\top}$ In addition, cattle and swine are fattened here and then shipped east. Peoria is also an important transshipment point for live stock. Great numbers of cattle and swine are collected from the surrounding country, fed, watered, assorted, and reshipped. These prompty became important activities in Peoria upon the development of its railroad connections. ${ }^{8}$ The Peoria Union Stock Yards were opened about 1877.

\footnotetext{
1 Twe]fth Census, Y. 7, p. cxci.

2 Idem.

Idem, p. exr. It was outranked by Chicago; Springfield, Ohio; Racine, Wisconsiu; and South Benil. Indiana, named in order of imprortance.

4 Tweifth Census, V. 10, ก, 350.

s Ballance: History of Peoria, p. 125.

a Ballance: Hintory of l'eoria, np. 12.5-127: Western Journal, V. 2, p. 268; Hunt's Merchants Magazine, $\downarrow$, 41, pp, 689-690; History of Peoria County, p. 555.

${ }^{7}$ Census Bulletin $52, \mathrm{~m} .49 .49$.

\& Sixth Annual lipport of Trade and Commerce of Peoria, p. 11; History of Peoria County, op. 541, 52; Gould: Peoria Directory, 1s-0-1, F. 6; Porter: The West in 1880, p. 538.
} 
Other industries. - It will be impossible to interpret here all the remaining industries of Peoria. Cooperage is fifth in importance, and completes the list of manufactures, the value of whose products exceeded 1 million dollars in 1905 . It is dependent chiefly on the liquor industry.

The decline in the milling business is one of the more interesting facts in connection with the minor industries. Flour was one of the leading manufactures of the earlier period and certain facts suggestive of its importance down to 1850 have been given (p. 110). The industry continued to grow until 1870 . There were then eight large mills in the city, which manufactured 573,500 barrels of flour. This flour was shipped south, east and even to Europe. ${ }^{1}$ From that date the milling interests of the city declined. In 1880, little Peoria flour was shipped out of the State. ${ }^{2}$ In 1905 the value of the product was less $\left(\$ 593,527^{3}\right)$ than in $1855\left(\$ 650,000^{ \pm}\right)$, and only three mills were ruming. This appears to mean that Peoria found it impossible to compete with flour from the northwest. ${ }^{5}$ The local mills no longer control even the home market. Peoria capital and enterprise find more profitable employment in the great industries discussed above, in the development of which geographic conditions give the city distinct advantages.

Aside from the manufacture of grain products Peoria does an extensive business in storing, transferring, and re-shipping grain, especially corn. The first elevator is said to have been erected in $1866 .{ }^{6}$ In 1872 there were five, and the business of warehousing grain was described as having become one of the leading interests of the city. ${ }^{7}$ As a collecting point for corn, Peoria ranked fourth among the cities of the United States in 1907, bcing led only by Chicago, St. Louis, and Omaha. ${ }^{8}$

The settlement of Germans in Peoria led to the early manufacture of beer. ${ }^{9}$ The product in 1905 was valued at $\$ 887,570$. . $^{10}$

In addition to the manufactures noted above, the census reports nearly 70 distinct industries of varying, but very minor importance. ${ }^{11}$ The total value of the products of all manufacturing industries for 1905 was $\$ 60,920,411 .^{12}$ The value of all industries in 1900 was $\$ 48,871,596 .^{13}$ The city accordingly gained 24.6 per cent in five years.

${ }^{1}$ Gonld's Peoria Directory, 1850-1, p. 5 ; History of Peoria County, p. 452. Peoria exported 30,000 barrels of flour to Great Britain in 1872 (Third Annual Report to Peoria Board of Trade, p. 23)

"IIistory of Peoria County, pp. 55S-559.

${ }^{3}$ Census Bulletin 52 , pp. $48 \cdot 49$.

+15 istory of Peoria County, p. 452

G The value of the four and grist mills products of Minnesota was 14.1 per cent of the total for the United States (Twelfth Census, V. 9, p. 357) in 1900. The industry centers in Minneapolis, favorably situated with reference to the wheat fields, and having the great advantage of the water power ifforded by the falls of St. Anthony.

Jistory of Peoria County, p. 540.

7 Third Annual Report to Peoria Board of Trade, pp. 18.19.

8 Fiftieth Annual Report, Chicago Board of Trade, p, 173.

Dallance: History of Peoria, pp. 146-147.

${ }^{10}$ Census Bulletin 52, pp. 48-49.

1 The nore important are in alphabetical order: Bakery products; brooms and brushes; carriages and wagons; cars and shop construction work; copper smithing and sheet iron work; food preparations; foundry and machine shop products; furniture; gypsum wall plaster; lumber products; mineral and soda waters; nodeis and patterns; printing and publishing; saddlery and barness; stoves and furnices; tinware; tobacoo, cigars and cigarettes. (Census Bulletin 52, pp. $48-49$.

${ }_{12}$ Census Bulletin 52, p. 49.

1.3 Twelith Census, V. 8, p. 1001. 


\section{MANUFACTIRING OUTSIDE PEORIA.}

Extensive manufacturing outside of Peoria is confined to Pekin. Its advantages are the same in kind as those of Peoria, though not so great in some particulars. Various corn prorlucts are the principal articles made. The value of the prolucts of all its industries was \$12 268,021 in 1900. ${ }^{1}$

It seems likely that East I'eoria will become an increasingly inportant industrial center. It is situated directly across the river from Peoria at the muth of Farm Creek V alley and upon its fan, which affords an almundance of land for factories. The industries will of course be thone of Peoria itself.

A zinc plant has recently heen established at De Pue, which is expected to give employment to 1.500 to 2.000 men. This promises to transform the place into a thriving little city.

\section{Existing Mericelterat. Coxditons.}

Products. ${ }^{2}$ - Corn continues to be the most inportant crop of the area unter liscussiom, as might be inferred from figure 46 . With two exceptions each census has shown the corn yield of the six comnties to $1 x$ more than twice as great as the combined vield of all uther grains; unce $(1880)$ it was wer four times as large. This specialization is largely due to the character of the soil (footnote 4. p. 11t) and to the demand for corn by the clistilleries and for the fattening of stock, rather than to climatic conditions.

Wheat was at first the second crop and oats third. Since 1860 , however, the proluction of wheat has weatly decreased, the crop of 1899 being less than one-twenty-eighth that of 1860 . On the other hand the production of oats has rapidly increased, the crop of 1899 being more than 13 times as large as that of 186 ) and over 227 times the size (in bushels) of the 1890 wheat crop. Oats were first reported as the second crop in the census returns for 1870 . Barley, rye, and hay have always been suborlinate crops.

Certain bottom and terrace lands near Peoria are profitably nsed for general truck warlening, and the husiness would probably prove successful orer large areas of smilar land now of little use. Large quantities of melons for the Peoria market are grown on the more sandy portions of the Chillicuthe and spring liay terraces. Successul experiments in the growth of small fruits have been made on the hilly ravine land fordering Illinois Valley. This industry also appears capable of extensive teveloment, particularly in the vicinity of Peoria.

Hater supply- I I ith few exceptions the wells of the region terminate in the drift and are supplied by seepage of ground water from the drift. A portion of the rain sinks into the ground, which, below a cer-

${ }^{1}$ Twelfth Censtus, Y. 8, pp. 1028-1029.

2. Irricultural statistios for the area nay be found in Seventh Census, op, 730-731; Eighth Census, Igriculture, $\mathrm{P}_{1}$, 30-37; Contpendium Ninth Census, $1 \mathrm{P}$, 726-729; Compendium Tenth Census, 11). T60-763; Elesenth' Cemus, Agriculture, po. 362-363; Twelfth Census, V. 6, pp. 160-161. 
tain level, is fuil of water. This level the level of ground water or water table) varies from time to time at any given place, and from place to place at any given time. It is higher in periods of heavy rain, and lower during periods of drought. It changes from point to point because of unequal precipitation and for other reasons. To contain water permanently, the botton of a well must be below the lowest level of ground water at that place; it will then fill with water to the height of the water table in the arljacent rock or earth. Because of the conditions indicated, wells must be sunk to different depths. Ninetyfive "leep wells" in Iireau County range in depth from 45 to 412 feet and average 200 feet. ${ }^{1}$ The great majority of the wells of the area are much shallower. When an aisundant water supply had been obtained upon the tpland prairies by wind mills from wells, one of the serious early problems of the praties was solved. The water table beneath the porous terraces of llinois Valley is lown nearly to the level of the river, to which, accorlingly, terrace wells must be dus. The depth of a terrace well, therefore indicates approximately the elevation of its top above the Illinois. The artesian wells of the area were noted on page 20 .

The distribution of land values. The distribution of land values is determined by various factors, chiefly the character of the soil, the topography, and the accessibility of markets. The typical black prairie lands of the trpe so long avoided have recently sold for $\$ 175.00$ to $\$ 200.00$ an acre, and are sometimes heid at even higher figures. The more uneven yellow clay lands nearer Illinois Valley are less valuable, but are variously estimated from $\$ 60.00$ to $\$ 110.00$ or more per acre. Several real estate men report these lands to have greater value west of the valley than east of it, and offer an interesting explanation. West of the valley, winter winds are said to blow large quantities of fune material from fali-plowed fields and black prairies to the irregular belt of dominantly yellow clay land east of them, increasing the fertility and value of the latter. $\dot{O}_{n}$ the east sicle of the valley the situation is reversed, the prevailing winds carying material from the yellow clay lands near the river to the black prairie farms situated farther back from the valley. Timbered bluff lands range from $\$ 20.00$ or less an acre, to $\$ 55.00$ or more. Terrace lands are said to vary from $\$ 70.00$ or less where especially sandy, to $\$ 100.00$ or $\$ 125.00$, particularly near the valley biuffs where they have been enriched ly wash from the uplands. Bottom lands viry greatly in value. Many swampy tracts, subject to frequent inundation, are at present practically worthless. Other higher and drier areas that are suited to truck gardening are of great value.

The figures quoted above have no exact value and serve only to show, in a general way, the striking variations in land values between the several geographic divisions of the area. 


\section{The Hexinepin Canal.}

Agitation for the recently opened canal from the vicinity of Hennepin to the Mississippi (fig. 47) began in 1836. ${ }^{2}$ From that time until Congress provided for its construction in 1800 , the canal project was frequently before the public. The general assemblies of Iowa

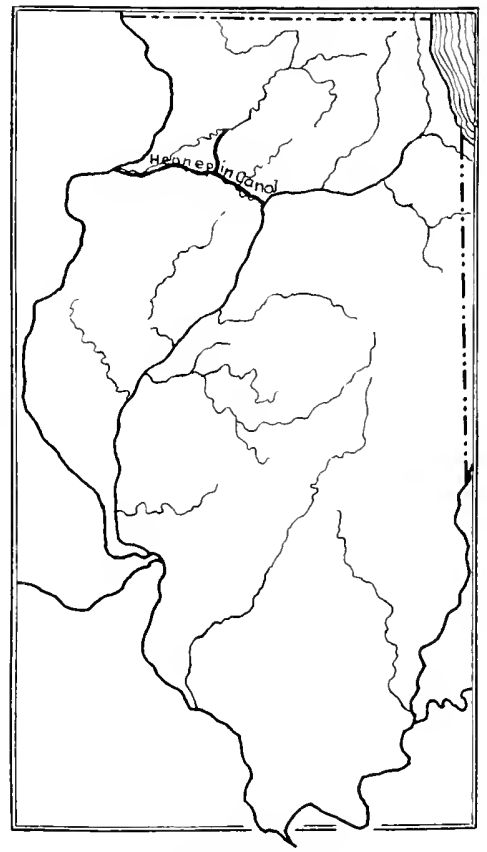

Fic. 47. Mall thewing route of Hempepin canal.

and Illinois memorialized Congress for the canal on a number of occasions; it was urged by the boards of trade of various cities conventions were helel to further the enterprise. The government meanwhile made survers looking to the cant in 1870, 1882, and in 188.5-86 A private survey was made as early as $1866 .^{2}$

1 Matson: Reminiscences of Burenu County, p. 405 .

2 House Executive lhemments, 5uth Congres, First Session, 1. 5, 1. 213s. 
Various arguments were advanced in favor of the canal, ${ }^{1}$ of which the following were chief: (1) It was alleged that railroad freight rates were exorbitant, and that the products and imports of the region, largely heavy and bullsy articles, required the cheaper transportation that the canal would itself furnish, and that it would compel the railroads to supply. A saving of about one-half was anticipated in the transportation of grain. (2) An immense grain producing area would be benefited, for the influence of the canal would extend west of the Mississippi into Iowa, south along the Mississippi to a point below Keokuk where the Illinois would afford the shortest water route to the east, and northward to St. Patrl. It would permit the through shipment of grain from the upper Mississippi, for example, to Chicago where low lake rates were available, thus avoiding the transfer from boats to rail at LaCrosse, Savanna, or other river towns. (3) Lower freight rates would enable the northwest to compete with greater success for the European grain trade. (4) It was considered doubtful whether the railroads could long handle the rapidly growing grain trade of the northwest.

The canal was doubtless first suggested by the westward course of upper Illinois River, and its relative nearness where it turns toward the south, to the Mississippi. The eastern terminus of the canal was accordingly fixed approxinnately by the great bend of the Illinois and by the valley of Bureau Creek, which furnished an easy route by which the canal could reach the summit level to the west.

The Hennepin Canal is only 7 feet deep, and has inadequate connection with Lake Michigan through the Illinois and Michigan Canal. It cannot he of great commercial importance until the "Deep) Waterway" is built. Meanwhile it will be simply a local highway, regulating local freight rates.

\section{The Deep Waterway.}

The future development of the middle Illinois Valler is destined to be profoundly affecterl by the projected Lake-to-Gulf Deep Waterway. It has been apparent for some years that the federal government must sooner or later create a Deep Waterway from Chicago through Illinois Valley to St. Louis and the Gulf of Mexico. The need for such a waterwav has become imperative. It is required alike by inlan'l and maritime commerce. Indeed, the products and trade of the upper Mississippi Valley have of late increased so much faster than the transportation facilities of the railroads, that leading railroad officials, fomerly the enemies, as a class, of inland waterways, now advocate their improvement to assist in handling the traffic.

The Chicago Sanitary and Ship Canal, opened in 1900 at a cost of about 50 million dollars while built primarily to dispose of the sewage of Chicago, was intended also, as its name implies, to be a link in the

\footnotetext{
1 Typical discussions occur in Annual Repott Chief of Engineers, I. S. Army, 1853, p. 17s0 et seq.: From Lake Michiran to the Mississippi river (panphlet of Michigan and Mississippi Canal Commission); ard Henderson: The propoced Waterway from Lake Michigan to the Mississippi via the Illinot and Mississipui Canal (World's Columbian Water Commerce Congress pamphlet).
} 
projected Deep Waterway. It was proviclell by state law that whenever the United states completed the waterway to St. Louis, it should be given control of the (hicago (anal for navigation purposes.' It was estimated in 1\%5, following a federal survey of the lllinosis, that

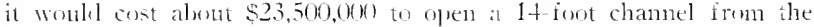
Chicago Canal at Lockport to the mouth of Illinois River." Chicago has accordingly already expended more than two-thirds of the sum required for the inprosment as far as the Mi-risippi. The conditions of molern commerce, particularly the fact that the cost per ton for transportation decreases as the size of the cargo increases, thus inviting increasingly large loats, rencler any such depth of water as that afforded by the Illinois and Michigan Canal, the Hennepin Canal or the Illinois, wholly inadequate. A deep waterway is required." A channel depth of If feet las been proposerl hecanse the work for such a deptly can le done economicalh, becatse the supply of water necessary to it can be provided easily, because it was thought that a similar depth could be counted on during most of the year in the Nississippi below St. Louis, really the outlet of the canal, and for other reasons. . Such a depth will not accommolate the most important lake traffic, for twothirds of the lake trade of Chicago, for example, is done with hoats drawing more than $1+$ feet of water, and the trade of the new Illinois waterway will probably be carried on in specially constructer steel barges, drawing 12 to 13 feet of water when loaded, and towed in groups by powerful tugs."

The nature of the demand for the Deep Materway and its probable importance may profitably be indicated in more letail. ${ }^{6}$

(1) Athowgh trade in the Mississippi lasin now noves largeiy along east and west lines, morth and south traffic promises to assume immense proportions in the immeliate future. The northern interior requires, in increasing quantity, such commolities as southern cuttom, tolnaco, sugit, rice and humber. The rapidly developing new South will lok to the lake and prairie plains and their cities for constantly increasing yuantitites of cereals, meat, iron and steel, machinery, wagons, wooden ware, canned products, and the like. During the last few rears, wale between the North and South has been seriously restricted by increaningly heary rail rates. It was said in 1906 that there was searecty a wholesale merchant or manufacturer in the midlle west who did not find himself barred by railnoal freight rates which were practically prohilitory, from the territory south of the Ohio. The only relief appears to be in the improvement of the waterways. ' The Deep

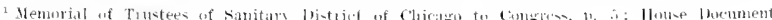

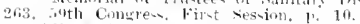

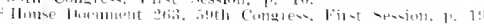

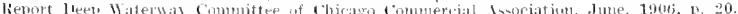

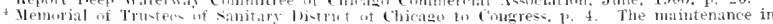

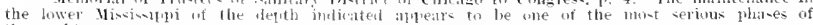
the problem.

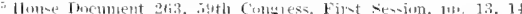

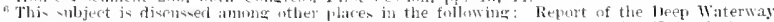

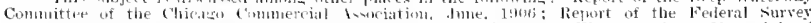

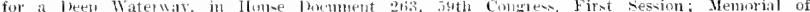

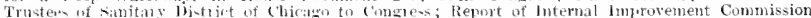

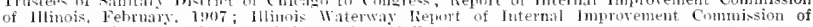

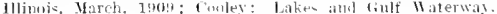

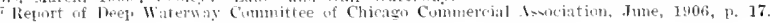


Waterway would doubtless exert a wholesome influence on railioarl charges to the south. Furthermorc, the traffic in question is for the most part in bulky, nonperishable commolities that seek water transportation because it is cheaper, and hecause they generally constitute through shipments.

(2) The Deep Waterway is clemanterl for the trate of the northern interior with the countries to the south and across the Pacific, a trade which will reach a volume, following the opening of the Isthmian Canal, at which present figures but vaguely hint. At present, moods from the upper Mississippi Valley destined for Mexico trequently go by way of San Franciseo, or by way of New Tork. Shipments to Central America or western South America usually go by rail to New York. and thence to Panama. The fact that such gonds must go half way across the continent by rail to ticlewater, imposes a heavy handicap upon the merchants and manufacturers of the middle west seeking to develop these foreign markets. ${ }^{1}$

(3) Such a Waterway would furnish the ship yards of the Great Lakes with an outlet to the sea. ${ }^{2}$ This would enable them to build yessels for the ocean trade, for they already possess minalerl arlvantages in the way of iron, coal, and timber."

(4) The Deep Waterway would enable the smaller vessels regularly cngaged on the Great Lakes to seek winter employment in the coasting tracle.

(5) Such a route would be open consirlerably longer each ruar than the Great Lakes, or any Deep Waterway that could be provided learlines eastward from them to the coast.

(6) The Deep Illinois Waterway would connect the largest cities of the interior, Chicago and St. Louis, and increase the rade between them, which recently amounted by rail to but little over a million fons a year.*

(7) The additional supply of water from Lake Michigan necessary to secure a depth of $1+$ feet in Illinois River (some 10,000 culic feet per second) would create a great amount of water power (estimated at 173,000 horse power ${ }^{5}$ ) in the upper lllinois Valley, where locks and dams must be used. Coupled with favorable transportation conditions. this power would doubtless lead to the extensive development of manufacturing.

(8) By drawing widely separater sections closer together commercially, the Waterway mould also acquire political importance, stringthening the political ties uniting the states, and cementing friendily rela. tions with the foreign countries to the south. In the unlikely arat of war upon the northern frontier. furthermore, the smaller loats of the navy could pass from the Gulf to the Lakes.

It is eviclent that the profected Deep Waterway acros Illiusis will be of national importance, for its benefits will not be confined in the immediate section through which it runs. They will extent 10 all points

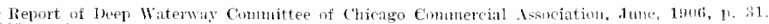

" House borment 36.3 , ioth Congres, Fint session, p. 1.7.

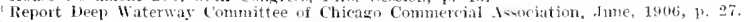

4 dem.

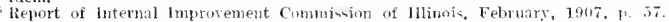


tributary to the Great Lakes, the Mississippi and its navigable rributaries, and the Gulf Coast. It is likely to be the most important link in any great related system of inland waterways which may be developed in the future.

The Deep Waterway will be a principal factor in the future economic history of the middle Illinois Valley, which will be benefited quite as much as any other district along the lines alrealy sugrested. I sevelopment unprecedonter in the region may confilently be expected in agriculture, commerce, and manufacturing; the rapid and complete exploitation of the coal depusits will be brought abut: and the now stationary river towns will le restored to importance, and a new period of growth inaugurated. With the Waterway adder to its other adrantages, Peoria will probably find it easy to maintain its position as the second city of the State.

It should be rememlered that the Deep Materway has been rendered possible and practicable by physiographic processes, and that all the results it produces will look lack to those processes as fundamental in. fluences.

\section{SUMMARY.}

The salient points in the preceding discussion may be briefly summarized as follows: (1) Geographic conditions determined the fact that the middle Illinois Valley was settled first and slowly by southerners, and later and rapidly by northerners, by whom its life was dominated. (2) The early settlers were distributed with reference to geographic features. They established themselves within easv distances of the Illinois or a navigable tributary, usually avoided the unlealthful flood-plain, frequently chose terrace sites, and, on the uplands, clung for years to the edge of the timber. (3) When the woodland was taken up, new comers were forced out upon the prairies. They occupied the smallest prairies with the best soil and water supply first, gratually filling them from their margins inward. (4) Geographic conclitions determined the occupations and mode of life of the valley. The settlers were forced to undergo many privations for years. The growing of corn and the raising of live stock were the leading industries. Timber, flowr, and meal were anong the pressing needs of the pioneer, and flour and saw mills were accordingly among the first improvements. The marketing of produce was difficult. At first Illinois River was the only outlet, but conflitions were unsatisfactory at the down-river cities, and active wason trade was developerl between the northern part of the area and Chicago. (5) Geographic conditions located the valley towns and determined the nature and extent of their progress. For a variety of reasons, Peoria promptly attaned leadership. (6) The river was a great commercial highway during the period of the Illinois stembnat, 1835-185.5. Its connection with Lake Michigan M the Illinois and Michigan Canal, made possible by physiographic processes, marked an epoch in the history of the valley, and morlified its life in important ways. (7) Certain disadvantages in the navigation 
of the river, for the most part geologically imposerl, math it an easy prey to railroad competition, anil, save in one or two cases, checlied the growth or inatugurated the decay of the river towns. (8) The occupation of the great prairies back from the streams and away from the timber was finally permitted in the decade $1850-1860$ by the huilding of railroads and the introduction of modern farming machinery. (9) lllinois River and the lllinois and Mlichigan Canal continue to le of great importance to the people of the region as regulators of railroad freight rates. (10) Geographic conditions led to the early development of mantifactures throughout the region, and determined their character. I ater, they gave Peoria high rank among the cities of the Uniter States in certain industries. (11) Commercial considerations seem about to compel the extensive improvement of Illinois River, and of its connection with Lake Michigan. This projected Deep Materway is likely to be one of the largest factors in the future economic life of the region, creating new activities, and stimulating old ones.

In conclusion it may be safely sail that geographic conditions have been leading factors in shaping the development of the middle Iilinois Valley. 


\section{INDEX}

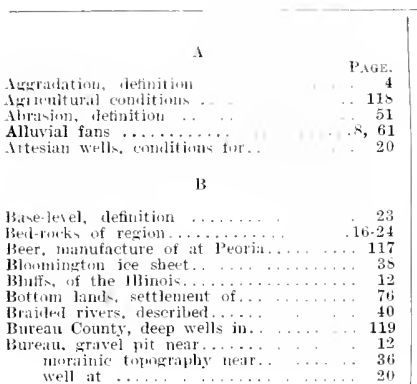

\section{C.}

Canis, dise Jemuepin.

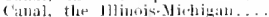

resule

develupment of projert...

extect an New orleans

inthence on contrs of triale....... 47

iufluence an railruid rates......... 108

Ganal transportation, alvantage of ..... 98

Cinal, Wabask o Erie, wfiect of ....... 97

Carbonifernus rocks .............. 16

Chicago Jrainaue (anal ............ 121

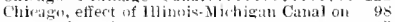
(Gutet, the .................... 47

Simitaryol ship Canal........ 121

Chilicothe, fluml-litin at ........... 10

rratel pit at................... 12

listury of .... .......... 10.5

laess neal ... ... 48

stutwash juta. ... . . . . . . . . 45

locks near ... ............ 16

sind hill: beat...

settlement af ............. 87

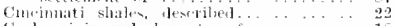

Coil, orisin amb rbatater uf.. ...... 1s urultiction of the illea........... 16

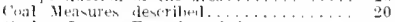

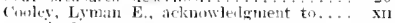
(ites ....................... 10

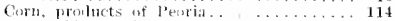

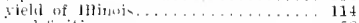

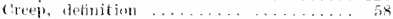

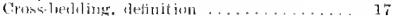

(Yow Cieek valley, setthement af....... 76

cule uf ermion, clethition.......... 23

1)

1)

fretine of, river towse... .... 104

water commerte.......... ...

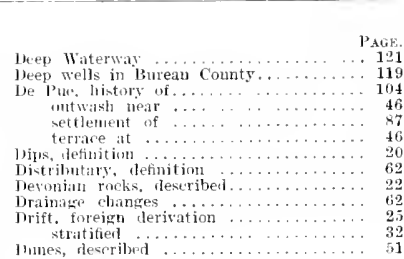

E

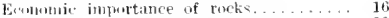
Erisjun, anditions aflectiug..........

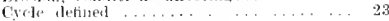

Farm Creek, alluvial fans of ......... 10

Floul distringe at Lasalle.............

"law plain, definet ..............

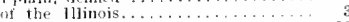

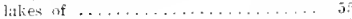

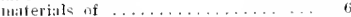

1 loun, manufarture of ............ 110 nijle at Peoria.............. 1, 117 Forl, Governor, work for Illinois River... 105 fimil, lefiution ................ 18

G

Galeni-Platterikle Jimestone, described, .. 21

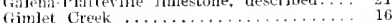

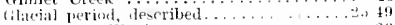

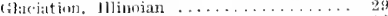
(ila fiers, formation of . . . . . . . . . faraje sugil, manufacture of ........ 11 .

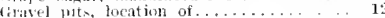
Gilucose manufacture of ........... 11.3. (imorelitul, morajuic topography near.... 36 rilge near .................. 14 firumd moritue, described.......... 32 fiullies, lescribed ....... . 50

\section{$H$}

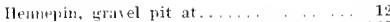

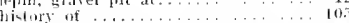
settlentert of ................. st

lemenis (mold, the............. 120

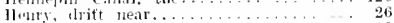

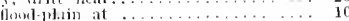
srave] pit at ............. 12

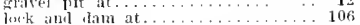

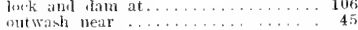

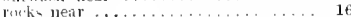

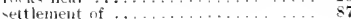




\section{Inder-Continuted.}

lloury history of 10.

livelis Ilollow, loess in.

History, recordes by roch

lie, work of

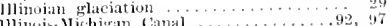
ettect on Chicago..............

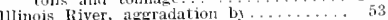
thatracter of .............. difficulty of navigatiun.......... 100 elfect of dams on................. $10 \mathrm{ti}$ indinence on ribluads late.......... 10 plius for improvement of ......... 10.i stembont navigation on .......... hat

I]linois Valley, the .............. 1

Industries, early developed. . . . . . . . . 111! of letorix ....................... 111

luter-glacial epochs .............. $34,3$.

linternitlent streans, defisition........ sit

lowilu loess, the ..................... 34

\section{K}

Kickapoo Creek, deposits of .......... 10 drift along roctis aloun

$\mathrm{L}$

Lacesl histery of ................... 16. terrace at ................. 46

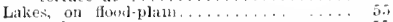

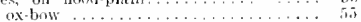

Lamarsh Creek, deposits of .........10, 16

Lamina, detinition ..................... 11

liaml values, affected by waterway...... . y! distribution of ............... 119

Latidle, Haul discharge at ..........

Levees, natural, detinition............. if

Leverett, Frank, acknowlediment to.... xi

Limevones, lestriptions of .......... 1i

l)evinitkn ...............

Galena Platteville $\ldots \ldots \ldots \ldots \ldots \ldots \ldots .21$

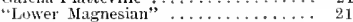

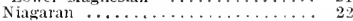

Loess, in Hicks' Hollotw.............. . . . 48

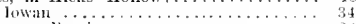
Itear Peoria .................

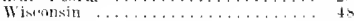

"Lower Magnesian" limestone.......... 21

Lumber, cust of .....................

II

Mackinaw River, deposits of ........... 1

Iautle rork, lescribed..................

Mamufuctures, development ot.......... 10.

Blarkets, early................... s?

Marpluette, rocks neib............. 1hi

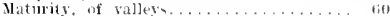

Mot packing imlustry............. 10y

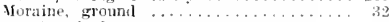
terninal

Moraini tomoraphy near Bureau............. newr froveland ................. 36

Meyer dake, origin of ............. 44

\section{N}

Natural leves, definition.

Navigable treams, infuence on settlenient

New Orleans, affected by cana. .........

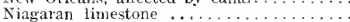

$(3$

I'Shis

Ghis River, protile of $\ldots \ldots \ldots \ldots, 4$

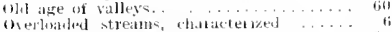

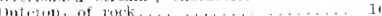

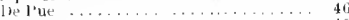

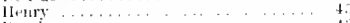

lenti: $\ldots \ldots \ldots \ldots \ldots, \ldots ., \ldots \ldots, 4$

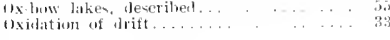

$\gamma^{2}$

leat, origin of . . . . . . . . . ., 1

J'ekin, wavel pit near............. 12

salmil hills year. 12

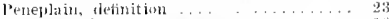

l'emsylvanian system ............. 10

losiria, brewing interests al ......... 117

lritt near ................. 27

early history of ......... .... . .

greit induries wf........... 111

"Natruwn" vear............ 10

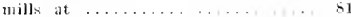

mitwakh at ................. 43

trititiel drit neat . . . . . . . . . 3

wel] at ............ . . n

Pexpian eluxil .... ............ 35

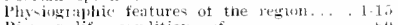

linner jift, comblition st .......... bi

l'Jutterille-tralena limestone .......... 21

l'iracy, detinitron .............

Popratition, early, distribution of ....... 76 inlluence of river and cana] on.... 5 .

lent.glacial changes . . . . . . . . . to-ti3

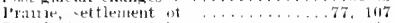

Pre-glacial topography ............ 33

I'rinfet, well recoril at , . . . . . 20, 1,23

l'rofiles of rivers................ . . .

pritnam, well at .................

R

Railrual, competitor of camal ........ 100 untunce on settlement.......... 10 107

rates, influenced by waterway....1ti, 108

Richmond shales ............... 22

Rislues, elay .................... 14

River, braided charater of ........... 40 intuence on railuoal rotew....... 10s

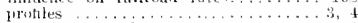
tom Ir and trade.............. s3 trade, decline of ............. st

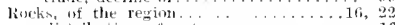
distribution of outerops............ 16 erorromic inumetance ot ........ 1ij

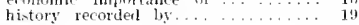
inthesce on topography............. 16

Eowe's Hollow, rork alomg ............ 16

\section{8}

hind dunes, described . . . . . . . . . . . 51 sand hill. on tertaces............... 12

suduture, oricin and descrintion of ..... 17 sit. Peter, described.............. 21

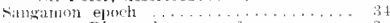

amamon River, character of ......... 2s

silisbury, R. 1), acknowledgrient to.... xi

ifmilits mine, section at .......... 1:

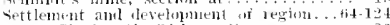
blite, Circimati (Richmond).......... jesonian ...............

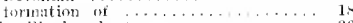
thelbyrilte ice shet............ 36

')

simil of terruces. . . . . . . . . . . . . . .

sparland, rocks netr............. 


\section{Index-Concluded.}

Spoon River, character of... ...... 29

spring lkity, fistort............. 10.

Stages of valley development......... 60

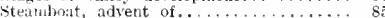

tratified drift

streani, intermitkent............ 56

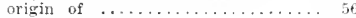
firisey of $\ldots \ldots \ldots \ldots \ldots \ldots$

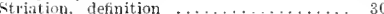

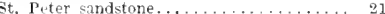

Ten Mile (teek, alluvial fans of ......... 10

Termil M.

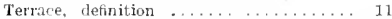

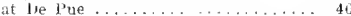

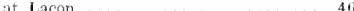

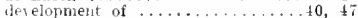

intherce on settlement............ 76

mittrials of ................. 11

Thenins Creels .....

Till, definition $\ldots \ldots \ldots \ldots \ldots \ldots \ldots \ldots \ldots$

Topography, pre-glacial ...........

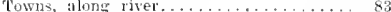
decline of ................. 104

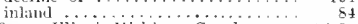

Tratfic on Illinois-Nichigan Canal...... 44-9y

Tranyortation, cost of ............. 71

Transiortation by water, advantage of ... as

U

U. \& Geological Survey, acknowledgment

tu .................. xil

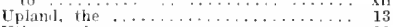

Tticn, rorks near...............

\section{Y}

PAGE.

Valley development, stages in.. 60

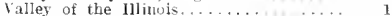

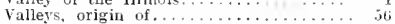
small

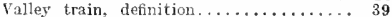

Falues of land, affected by waterway..... 99 distribution of ................. 119

W

Wabash and Erie canal, effect of...... 97

Wabash River, profile of . . . . . 4

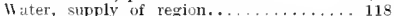
table, definition ................ 56

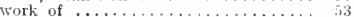

Waterway, the Deep.............. 121 as regulator of railroad rates....... 104

Weathering, defuition ............. 23

Well record at 1 enria.................. 8

Wesley, deposits near....... 10 rocks near ................. 16

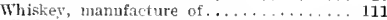

Hind work .................. 51

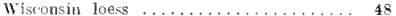

Woodland, settlement of ............ 77

Work of ice... ................. 29

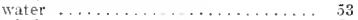

wind $\ldots \ldots \ldots \ldots \ldots \ldots \ldots \ldots \ldots \ldots \ldots$

Y

Yates, Governor, work for Illinois River... I06 louth of valleys................. 60 

Date Due

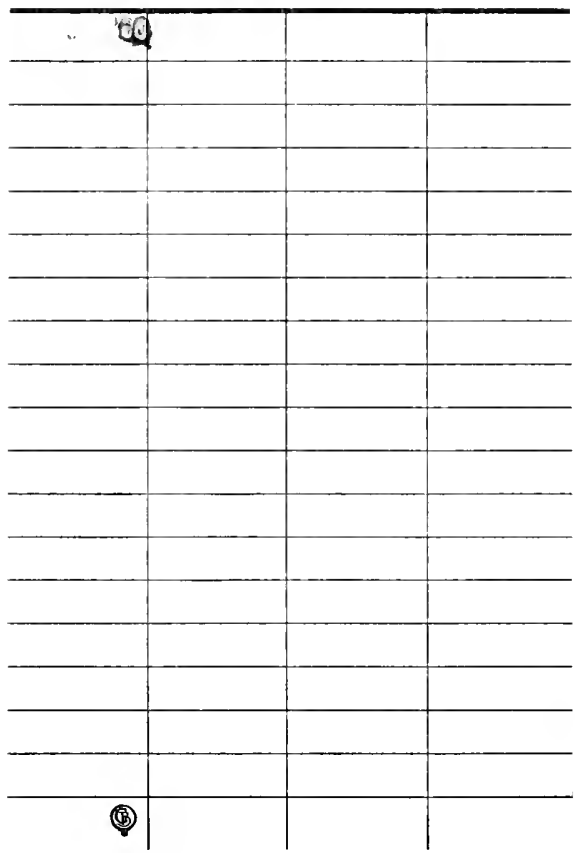






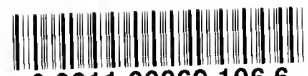 \\ 32311000691066}

/557.73B278G>Cl/

557.73

B278g

Barrows, $\mathrm{Ha}^{\mathrm{m}} \mathrm{I}$ an

Geography of the middle IIIinois valley.

\section{ELMHURST COLLEGE LIBRARY}

Elmhurst, Illinois

60126 
年

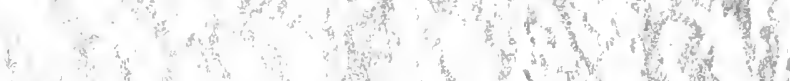

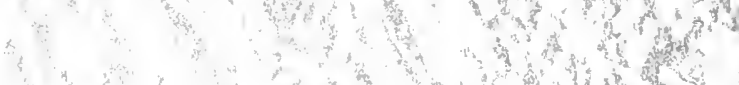

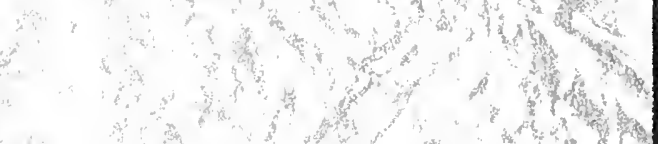
at

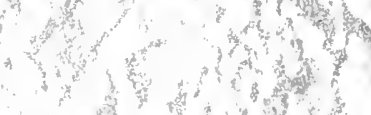
(1) is

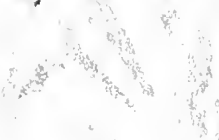
(1) 